DEPARTMENT OF THE INTERIOR

UNITED STATES GEOLOGICAL SURVEY

GEORGE OTIS SMITH, DIRECTOR

Bulletin 444

BIBLIOGRAPHY

OF

NORTH AMERICAN GEOT,OGY

FOR

1909

WITH SUBJECT INDEX

BY

JOHN M. NICKLES

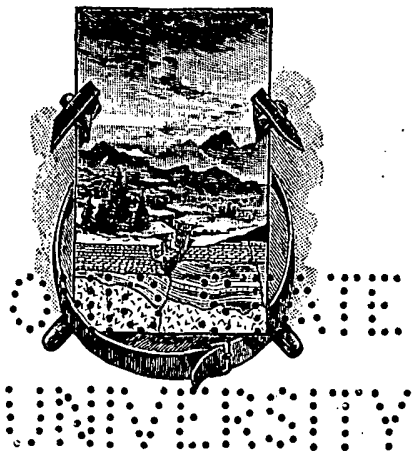

WASH I N TON

GOVERNMENT PRINTING OFFICE 1910 


$$
\begin{aligned}
& \text { QET } 75 \\
& \text { B9 } \\
& \text { nos } 4+4-498 \\
& \text { coppes }
\end{aligned}
$$

\footnotetext{
औओ औ

Ұ
} 


\section{CONTENTS.}

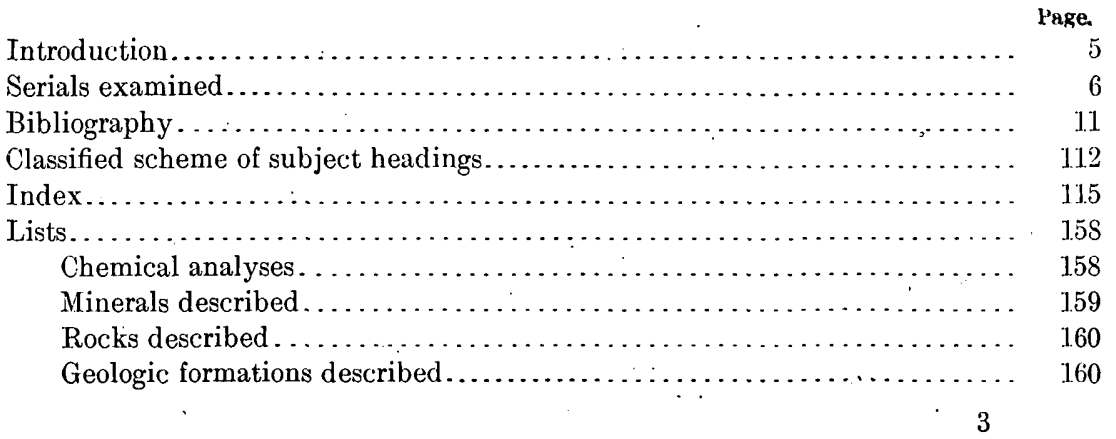





\title{
BIBLIOGRAPHY OF NORTH AMERICAN GEOLOGY FOR 1909, WITH SUBJECT INDEX.
}

\author{
By JoHn M. Nickies.
}

\section{INTRODUCTION.}

The bibliography of North American geology, including paleontology, petrology, and mineralogy, for the year 1909 follows the plan and arrangement of its immediate predecessors, the bibliographies for 1906-7 and 1908 (Bulletins 372 and 409 of the U. S. Geological Survey). It includes publications bearing on the geology of the continent of North America and adjoining islands, also Panama and the Hawaiian Islands. Papers by American writers on the geology of other parts of the world are not inćluded. Text-books and papers general in character by American authors are included; those by foreign authors are excluded unless they. appear in American publications.

As heretofore, the papers, with full title and medium of publication and explanatory note when the title is not fully self-explanatory, are listed under the authors arranged in alphabetic order. The author list is followed by an index to the literature listed. In this index the entries, in one alphabet, are of three kinds-first, subject, with various subdivisions, to enable the specialist to ascertain readily all the papers bearing on a particular subject or area; second, titles of papers, many of them abbreviated or inverted, under their leading words; and third, cross references, which have been freely used to avoid too much repetition. The subjects have been printed in black-faced type, the titles of papers and cross references in ordinary type. As it may not be always obvious which subject headings have been adopted, a classified scheme of those used immediately precedes the index.

The bibliography of North American geology is comprised in the following bulletins of the U. S. Geological Survey: No. 127 (17321892); Nos. 188 and 189 (1892-1900); No. 301 (1901-1905); No. 372 (1906-7); and No. 409 (1908). 


\section{SERIALS EXAMINED.}

American Academy of Arts and Sciences: Proceedings, vol. 44, nos. 6-26, vol. 45, nos. 1-3. Boston, Mass.

American Geographical Society: Bulletin, vol. 41. New York.

American Institute of Mining Engineers: Bulletin, nos. 25-36; Transactions, vol. 39. New York.

American Journal of Science, 4th series, vols. 27, 28. New Haven, Conn.

American Mining Congress: Papers and Addresses, 11th Annual Session; 12th Annual Session.

American Museum of Natural History: Memoirs, vol. 9, pts. 5, 6; Bulletin, vol. 26; Journal, vol. 9. New York.

American Naturalist, vol. 43. New York.

American Peat Society: Journal, vols. 1, 2, nos. 1-3. Toledo, Ohio.

American Philosophical Society: Proceedings, vol. 48. Philadelphia, Pa.

American Society of Civil Engineers: Transactions, vols. 62-65. New York.

Annales des mines, $6^{\circ}$ sér., t. 15, 16. Paris, France.

Annals and Magazine of Natural History, 8th ser., vols. 3, 4. London.

Appalachia, vol. 12, no. 1. Boston, Mass.

Arkansas Geological Survey: Slates of Arkansas. Little Rock, Ark.

Association of Engineering Societies: Journal, vols. 42, 43. Philadelphia, Pa.

Bernice Pauahi Bishop Museum: Memoirs, vol. 2, no. 4; Occasional Papers, vol. 4, no. 3. Honolulu, Hawaiian Islands.

Boston Society of Natural History: Proceedings, vol. 34, nos. 5-7. Boston, Mass.

Botanical Gazette, vols. 47, 48. Chicago, Ill.

British Columbia, Bureau of Mines: Annual Report of the Minister of Mines for 1908. Victoria, B. C.

Buffalo Society of Natural Science: Bulletin, vol. 9, nos. 2, 3. Buffalo, N. Y.

California Academy of Sciences: Proceedings, vol. 3, pp. 49-56. San Francisco.

California Journal of Technology, vols. 13, 14. Berkeley, Cal.

California Physical Geography Club: Bulletin, vol. 2, no. 2. Oakland, Cal.

California State Mining Bureau: Bulletin, nos. 54-56. San Francisco, Cal.

California, University of, Department of Geology: Bulletin, vol. 5, nos. 18-23. Berkeley, Cal.

Canada, Geological Survey: Summary Report for 1908; and miscellaneous publications. Ottawa, Ont.

- Canada, Department of Mines, Mines Branch: Miscellaneous publications. Ottawa, Ont.

Canada, Royal Society: Proceedings and Transactions, 3d ser., vol. 2. Ottawa, Ont.

Canadian Institute: Transactions, vol. 8, pt. 3. Toronto, Ont.

Canadian Mining Journal, vol. 30. Toronto and Montreal, Canada.

Carnegie Institution of Washington: Yearbook; no. 7, for 1908. Washington; D. C.

Carnegie Museum: Memoirs, vol. 4, nos. 3, 4; Annals, vol. 5, nos. 2-4, vol. 6, no. 1. Pittsburg, Pa. 
Cassier's Magazine, vol. 35, nos. 3-6, vol. 36, vol. 37, nos. 1-2. New York.

Centralblatt für Mineralogie, Geologie und Paleontologie, Jahrgang 1909. Stuttgart, Germany.

Chicago Academy of Sciences: Bulletin, no. 7, pt. 1, vol. 3, no. 2. Chicago, Ill.

Cincinnati Society of Natural History: Journal, vol. 21, no. 1. Cincinnati, Ohio.

Colorado Geological Survey: First Report; 1908. Denver, Colo.

Colorado School of Mines: Bulletin, vol. 4, nos. 3, 4. Golden, Colo.

Colorado Scientific Society: Proceedings, vol. 9, pp. 113-314. Denver, Colo.

Colorado, University of: Studies, vol. 7, nos. 2, 3. Boulder, Colo.

Connecticut Academy of Arts and Sciences (Publications of.Yale University): Transactions, vol. 14, pp. 171-236. New Haven, Conn.

Davenport Academy of Sciences: Proceedings, vol. 12, pp. 95-222. Davenport, Iowa.

Delaware County Institute of Science: Proceedings, vol. 4, nos. 2-4. Media, Pa.

Denison University, Scientific Laboratories: Bulletin, vol. 14, pp. 61-442. Granville, Ohio.

Deutsche geologische Gesellschaft: Zeitschrift, Bd. 61; Monatsberichte, nos. 1-12. Berlin, Germany.

Economic Geology, vol. 4. Lancaster, Pa.

Elisha Mitchell Scientific Society: Journal, vol. 25. Chapel Hill, N. C.

Engineering and Mining Journal, vols. 87, 88. New York.

Engineering Association of the South: Proceedings, vol. 20. Nashville, Tenn.

Engineering Magazine, vol. 36, nos. 4-6, vol. 37, vol. 38, nos. 1-3. New York.

Engineers' Club of Philadelphia: Proceedings, vol. 26. Philadelphia, Pa.

Field Columbian Museum: Geological Series, vol. 4, no. 1. Chicago, Ill.

Florida State Geological Survey: Second Annual Report. Tallahassee, Fla.

Franklin Institute: Journal, vols. 167, 168. Philadelphia, Pa.

Geographical Journal, vols. 33, 34. London.

Geological Magazine, new ser., decade 5, vol. 6. London.

Geological Society of America: Bulletin, vol. 19, no. 21, vol. 20, nos. 1-13. New York

Georgia Geological Survey: Bulletin, nos. 18, 19. Atlanta, Ga.

Harvard College, Museum of Comparative Zoology: Bulletin, vol. 52, nos. 7-14, vol. 53, nos. 3, 4; Memoirs, vol. 34 , no. 3, vol. 37 , vol. 38 , nos. 1., 3. Cambridge, Mass.

Illinois State Geological Survey: Bulletin, nos. 10-14. Urbana, Ill.

Illinois State Laboratory of Natural History: Bulletin, vol. 7, article 10, vol. 8, article 3. Urbana, IIl.

Imperial Earthquake Investigation Committee: Bulletin, vol. 3, nos. 1, 2. Tokyo, Japan.

Indiana Academy of Science: Proceedings for 1908. Indianapolis, Ind.

Indiana, Department of Geology and Natural Resources: 33d Annual Report. Indianapolis, Ind.

Institution of Mining Engineers: Transactions, vol. 36, pts. 2-5, vol. 37, vol. 38, pts. 1-2. Newcastle-upon-Tyne, England.

Iowa Geological Survey: Annual Report, vol. 19. Des Moines, Iowa.

Journal of Geography, vol. 7, nos. 5-10, vol. 8, nos. 1-4. Lancaster, Pa.

Journal of Geology, vol. 17. Chicago, Ill.

Kansas Academy of Sciences: Transactions, vol. 22. Topeka, Kans.

Kansas University Geological Survey, vol. 9. Lawrence, Kans.

Lake Superior Mining Institute: Próceedings, vol. 14. Ishpeming, Mich.

London, Geological Society: Quarterly Journal, vol. 65. London.

London, Geologists' Association: Proceedings, vol. 21, pts. 1-4. London.

Louisiana Geological Survey: Bulletin, no. 8. Baton Rouge, La. 
Mexico, Instituto geológico: Parergones, t. 2, nos. 8-10, t. 3, nos. 1-3. Mexico, D. F. Michigan Academy of Science: Eleventh Report. Lansing, Mich.

Mines and Minerals, vol. 29, nos. 6-12, vol. 30, nos. 1-5. Scranton, Pa.

Mining and Scientific Press, vols. 98, 99. San Francisco, Cal.

Mining Magazine, vol. 1. London.

Mining Science, vols. 57-60. Denver, Colo.

Mining World, vols. 30, 31. Chicago, Ill.

Minnesota Academy of Sciences: Bulletin, vol. 4, no. 2. Minneapolis, Minn.

Mississippi State Geological Survey: Bulletin, nos. 5, 6. Jackson, Miss.

Missouri Bureau of Geology and Mines: Biennial Report State Geologist for 1907-1908; vol. 9, pts. 1, 2. Jefferson City, Mo.

National Geographic Magazine, vol. 20. Washington, D. C.

Nature, vol. 79 , no. $2045-$ vol. 82 , no. 2096. London.

Nautilus, vol. 22, nos. 9-12, vol. 23, nos. 1-7. Philadelphia, Pa.

Neues Jahrbuch für Mineralogie, etc., 1909: Beilage Band, 27, 28. Stuttgart, Germany.

New Brunswick Natural History Society: Bulletin, no. 27 (vol. 6, pt. 2). St. John, N. B.

New Jersey Geological Survey: Annual Report of the State Geologist for 1908. Trenton, N. J.

New York Academy of Sciences: Annals, vol. 19, pts. 1, 2. New York.

New York Botanical Garden: Bulletin, vol. 5, no. 18, vol. 6, no. 20, vol. 7, no. 23. New York.

New York State Museum: 62d Annual Report; Bulletin, nos. 127-133. Albany, N. Y.

North Carolina Geological and Economic Survey: Biennial Report, 1907-8; Bulletin, no. 18. Chapel Hill, N. C.

North Dakota Geological Survey: Fifth Biennial Report. Grand Forks, N. Dak.

Nova Scotia Institute of Science: Proceedings and Transactions, vol. 11, pts 3, 4, vol. 12, pt. 1. Halifax, N. S.

Nova Scotia, Mining Society of: Journal, vol. 13. Halifax, N. S.

Ohio Geological Survey: Fourth Series, Bulletin 10. Columbus, Ohio.

Ohio Naturalist, vol. 9, nos. 3-8, vol. 10, nos. 1-2. Columbus, Ohio.

Ontario, Bureau of Mines: Report, vol. 18, pts. 1, 2; General Index to Vols. I-XVI. Toronto, Ont.

Ottawa Naturalist, vol. 22 , nos. 10-12, vol. 23, nos. 1-9.

Paleontographica, Bd. 55, Lief. 5-6; Bd. 56. Stuttgart, Germany.

Philadelphia Academy of Natural Science: Proceedings, vol. 61; Journal, 2d ser., vol. 14, pt. 1. Philadelphia, Pa.

Philadelphia, Geographical Society of: Bulletin, vol. 7. Philadelphia, Pa.

Popular Science Monthly, vols. 74, 75. New York.

St. Louis Academy of Science: Transactions, vol. 18, nos. 2-5. St. Louis, Mo.

School of Mines Quarterly, vol. 30, nus. 2-4, vol. 31, no. 1. New York.

Science, new ser., vols. 29, 30. New York.

Sierra Club Bulletin, vol. 7, nos. 1, 2. San Francisco, Cal.

Smithsonian Institution: Annual Report for 1908; Miscellaneous Collections, vol. 52, 54, pp. 1-329.

Sociedad científica "Antonio Alzate:" Memorias y revista, t. 25, nos. 5-12. Mexico, D. F.

Sociedad geologica mexicana: Boletín, t. 5, 6, pt. 1. Mexico, D. F.

Société géologique de Belgique: Annals, t. 35, liv. 4, t. 36, liv. 1-3. ' Liége, Belgium. Southern California Academy of Sciences: Bulletin, vols. 7, 8. Los Angeles, Cal.

Torrey Botanical Club: Bulletin, vol. 36. Lancaster, Pa.

Torreya, vol. 9. Lancaster, $\mathrm{Pa}$. 
Tschermaks Mineralogische und petrographische Mitteilungen, N. F., Bd. 27, 28. Vienna, Austria.

U. S. Department of Agriculture: Field Operations of the Bureau of Soils, Ninth Report. Washington, D. C.

U. S. Geological Survey: 30th Annual Report; Professional Papers 59, 61, 64-67; Bulletins 341, 356, 360, 361, 364, 367, 368, 370-397, 399, 401-405, 409, 411, 412, 414, 416, 423; Water-Supply Papers 221, 223-236, 242; Geologic Atlas of the United States, folios 162-170; Minerál Resources for 1908. Washington, D. C.

U. S.. National Museum: Proceedings, vols. 36, 37, pp. 1-419; Bulletin, nos. 62-69. Washington, D. C.

Virginia Geological Survey: Bulletin, nos. I-A, II-A. Charlottesville, Va.

Washington Academy of Sciences: Proceedings, voi..11, pp. 1-299.

Washington Philosophical Society: Bulletin, vol. 15, pp. 133-187. Washington, D. C.

West Virginia Geological Survey, vol. 4; County Reports, Marshall, Wetzel, and Tyler Counties. Morgantown, W. Va.

Wisconsin Academy of Science, Arts, and Letters: Transactions, vol. 16. Madison, Wis.

Wisconsin Geological and Natural History Survey: Sixth Biennial Report. Madison: Wis.

Wisconsin Natural History Society: Bulletin, vol. 7. Milwaukee, Wis.

Wisconsin, University of: Bulletin, Science Series, vol. 3, nos. 9, 10. Madison, Wis.

Wyoming Historical and Geological Society: Proceedings and Collections, vol. 1.0. . Wilkes-Barre, Pa.

Zeitschrift für Gletscherkunde, Bd. 3, H. 3-5, Bd. 4, H. 1. Berlin, Germany.

Zeitschrift für Krystallographie, Bd. 46, 47, H. 1-2. Leipzig, Germany.

Zeitschrift für praktische Geologie, Jg. 17. Berlin, Germany. 



\section{BIBLIOGRAPHY.}

Adams, Frank Dawson.

1. Report on the investigation into the flow of rocks.-Carnegie Inst. of Washington, Yearbook no. 7, 1908, pp. 205-206, 1909.

Outlines briefly the progress of the investigation and some of the results obtained.

2. On the origin of the amphibolites of the Laurentian area of Canada.--Jour. Geology, vol. 17, no. 1, pp. 1-18, 1909.

3. The basis of pre-Cambrian correlation.-Jour. Geology, vol. 17, no. 2, pp. 105-123, 1909.

Discussion by C. R. Van Hise, pp. 118-122.

Adams, Frank D., and Barlow, Alfred E.

4. The nepheline and associated alkali syenites of eastern Ontario.-Roy. Soc. Canada, Proc. and Trans., 3d ser., vol. 2, sect. 4, pp. 3-76, 14 pls., 1908.

Describes the distribution, geologic relations, general petrographic character, mineralogic composition, and the several occurrences.

Adams, W. J,

5. What is an ore?-Min. and Sci. Press, vol. 98, p. 548, April 17, 1909.

Gives a definition for the term "ore."

Agraz, Juan S.

6. Estudio quimico de unà meteorita del Estado de Durango.-Soc. Geol. Mexicana, Bol., t. 6, pp. v, 89-91, 1 pl., 1909.

Describes the composition of a meteorite from the Rancho de Los Arenales, near Cordon de la Pastora, State of Durango, Mexico.

Aguilera, José G.

7. Catalogo de los temblores (macroseismos) sentidos en la Republica Mexicana durante los años de 1904 a 1908.-Mexico, Inst. Geol., Parerg., t. 2, no. 10 , pp. 389-467, 1909.

A list of earthquakes felt in Mexico from 1904 to 1908.

8. Algunos fósiles del cretacico mexicano.-Soc. Geol. Mexicana, Bol., t. 5, p. 12, 1909.

Gives a list of fossils, including a new genus and 15 new species, without descriptions, from the Cretaceous of Mexico.

9. Algunos criaderos de fierro de la Republica [Mexico].-Soc. Geol. Mexicana, Bol., t. 5, pp. 67-89, 5 pls., 1909.

Describes iron deposits of Mexico. Includes analyses of igneous rocks.

10. The carboniferous deposits of northern Coahuila.-Eng. and Min. Jour., vol. 88, pp. 730-733, October 9, 1909.

Describes the general geology of the coal fields of Coahuila, Mexico, the occurrence, character, and relations of Cretaceous coal-bearing strata, and the character and occurrence of the coal beds.

11. The Instituto Geologico de Mexico._Eng. and Min. Jour., vol. 88, pp. 857-859, 7 figs., October 30, 1909.

Describes the origin and work of the Geological Survey of Mexico. 
Alden, William C.

- 12. Concerning certain criteria for discrimination of the age of glacial drift sheets as modified by topographic situation and drainage relations.-Jour. Geology, vol. 17, no. 8, pp. 694-709, 6 figs., 1909. Abstract: Science, new ser., vol. 29, p. 628; A pril 16, 1909.

The discussion is based upon the character of the drift in southern Wisconsin and northern Illinois.

13. The Pleistocene phenomena of southeastern.Wisconsin.-Abstract: Science, new ser., vol. 29, p. 557, A pril 2, 1909.

14. The glacial phenomena of southeastern Wisconsin.-Abstract: Science, new ser., vol. 29, p. 628, April 16, 1909.

Alderson, Matt. W.

15. Some ore deposits connected with placers.-Min. World, vol. 31, pp. 229-230, 1 fig., July 24, 1909.

Describes ore deposits produced by thermal waters.

Aldrich, Thomas H., jr.

The treatment of the gold ores of Hog Mountain, Alabama.-Am. Inst. Min. Eng., Trans., vol. 39, pp. 578-583, 1909. See no. 11 of the bibliography for 1908, U. S. Geol. Survey, Bull. 409, p. 9.

Allen, R. C.

16. The occurrence and origin of the brown iron ores of Spring Valley, Wisconsin.Michigan Acad. Sci., 11th Rept., pp. 95-103, 2 pls., 4 figs., 1909.

17. Iron formation of Woman River area [Ontario].-Ontario, Bur. Mines, 18th Ann. Rept., vol. 18, pt. 1, pp. 254-262, 5 figs., 1 map, 1909.

Describes the geology and structure of the range and the occurrence, character, and relations of the iron ores, the igneous origin of which is discussed.

Allen, Roy Hutchins.

18. Notes on Mother Lode mine in British Columbia.-Eng. and Min. Jour., vol. 88, pp. 1101-1103, 3 figs., December 4, 1909.

Includes notes on the geology and the occurrence of the copper ores.

19. Mines of the Granby Consolidated, Phoenix, B. C.-Eng. and Min. Jour., vol. 88, pp. 1260-1262, 1 fig., December 25, 1909.

Includes notes on the local geology and the occurrence and character of the copper ores.

Allen, Eugene T., and White, W. P.

20. Diopside and its relations to calcium and magnesium metasilicates; with optical study by Fred. Eugene Wright and Esper S. Larsen.-Am. Jour. Sci., 4th ser., vol. 27, pp. 1-47, 1 pl., 14 figs., January, 1909.

Ames, Mary Lesley.

21. Life and letters of Peter and Susan Lesley. New York, G. P. Putnam's Sons, 1909. 2 vols.

Ami, Henry M.

22. [Report on] invertebrate paleontology.-Canada Geol. Survey, Summ. Rept., 1908, pp. 179-181, 1909.

Anderson, Glenn.

23. Notes on economic geology of the Cobalt area, Ontario.-Eng. and Min. Jour., vol. 88 , p. 786 , October $16,1909$.

Anderson, Robert.

24. An occurrence of asphaltite in northeastern Nevada.-U. S. Geol. Survey, Bull. 380 , pp. 283-285, 1909. 
Anderson, Robert-Continued.

25. Geology and oil prospects of the Reno region, Nevada.-U. S. Geol. Survey, Bull. 381-D (advance chapter), pp. 3-17, 1909.

Describes the general geology, the volcanic rocks, the occurrence, character, relations, and origin of Tertiary sedimentary rocks, and prospecting for oil.

26. Two areas of oil prospecting in Lyon County, western Nevada.-U. S. Geol. Survey, Bull. 381-D (advance chapter), pp. 18-21, 1909.

Includes notes upon the geology.

Anderson, Tempest.

27. The volcanoes of Guatemala.-Liverpool Geog. Soc., Trans. and 17th Ann. Rept., pp. 11-15, 1909.

28. The Soufrière of St. Vincent; the changes subsequent to the eruption of 1902.Abstract: British Assoc. Adv. Sci., Rept. 78th Meeting, pp. 706-707, 1909.

Anonymous papers. See page 111.

Anrep, S. A.

Investigation of the peat bogs and peat industry of Canada during the season 1908-9.-See Nyström and Anrep, no. 903.

\section{Arkansas Diamond Company.}

29. A brief account of the discovery and investigation and the official reports of geologist and mining engineer on the occurrence of diampnds in Pike County, Arkansas. Little Rock, 1908. 38 pp.

Includes reports by John T. Fuller and Henry S. Washington.

Arnold, Ralph.

30. Notes on some rocks from the Sawtooth Range of the Olympic Mountains, Washington.-Am. Jour. Sci., 4th ser., vol. 28, pp. 9-14, July, 1909.

Describes the general geology and the characters of sedimentary, metamorphosed sedimentary, and igneous rocks.

31. Paleontology of the Coalinga district, Fresno and Kings counties, California.U. S. Geol. Survey, Bull. 396, 173 pp., 30 pls., 1909.

Describes the stratigraphy of the region, comprising Mesozoic and Cenozoic formations, with lists of fossils showing distribution, and gives systematic descriptions of species.

32. Environment of the Tertiary faunas of the Pacific coast of the United States.Jour. Geology, vol. 17, no. 6, pp. 509-533, 5 figs., 1909.

Discusses the correlation of Tertiary formations of the Pacific coast States.

Description of the Santa Cruz quadrangle, California.-See Branner and others, no. 138.

Arnold, Ralph, and Johnson, H. R.

33. The earthquake rift in eastern San Luis Obispo County, California.-Abstract: Science, new ser., vol. 29, p. 558, April 2, 1909.

34. Sodium sulphate in Soda Lake, Carriso Plain, San Luis Obispo County, California.-U. S. Geol. Survey, Bull. 380, pp. 369-371, 1909.

Ashley, George Hall.

35. Supplementary report (to report of 1898) on the coal deposits of Indiana.Indiana, Dept. Geology and Nat. Res., 33d Ann. Rept., pp. 13-150, 4 pls., 1 fig., 1909.

36. Stratigraphy and coal beds of the Indiana coal field.-U. S. Geol. Survey, Bull. 381-A (advance chapter), pp. 5-14, 1909.

37. Significant time-breaks in coal deposition.-Abstract: Science, new ser., vol. 30, p. 124, July 23, 1909. 
Ashley, Harrison Everett.

38. The colloid matter of clay and its measurement.-U. S. Geol. Survey, Bull. 388, 65 pp., 1 pl., 9 figs., 1909.

Aston, James.

39. The solidification of alloys and magmas.-Jour. Geology, vol. 17, no. 6, pp. 569-585, 11 figs., 1909.

Atwood, Wallace W.

40. Glaciation of the Uinta and Wasatch Mountains.-U. S. Geol. Survey, Prof. Paper 61, 96 pp., 15 pls., 24 figs., 1909.

41. Mineral resources of southwestern Alaska.-U. S. Geol. Survey, Bull. 379, pp. 108-152, 2 pls., 13 figs., 1909.

42. Geologic studies in the Alaska Peninsula.-Abstract, Science: new ser., vol. 29, p. 636, April.16, 1909.

Babb, Percy Andrus.

43. Dulces Nombres quicksilver deposit, Mexico.-Eng. and Min. Jour., vol. 88, pp. 684-686, 4 figs., October 2, 1909.

Describes the geology, occurrence, and character of quicksilver deposits in the state of San Luis Potosi, Mexico.

44. The Magistral copper district, Mexico.-Eng. and Min. Jour., vol. 88, pp. 1215-1216, 2 figs., December 18, 1909.

Includes notes on the local geology and occurrence of copper ores near Ameco, State of Jalisco, Mexico.

Bagg, Rufus Mather, jr.

45. Notes on the distribution of the mastodon in Illinois.-Univ. Illinois Bull., vol. 6 , no. 17, The University Studies, vol. 3, no. 2, pp. 45-56, 2 pls., January, 1909 .

46. Casts of Foraminifera in the Carboniferous of Illinois.-Illinois State Geol. Survey, Bull. no. 14, pp. 263-271, 1 pl., 1909.

Bain, Harry Foster.

47. Work of Illinois Geological Survey.-Min. World, vol. 30, pp. 537-538, March 20, 1909.

48. Petroleum fields of Illinois.-Min. and Sci. Press, vol. 99, pp. 153-156, 4 figs., July $31,1909$.

49. Administrative report for 1908.-Illinois State Geol. Survey, Bull. No. 14, pp. 1-30, 1. pl: (map), 1909 (1910).

Bain, Harry Foster, and others.

50. Studies of Illinois coal.-Illinois State Geol. Survey, Bull. no. 14, pp. 183-253, 3 pls., 3 figs., 1909.

Baker, F. C.

51. Description of a new fossil Lymnæa [nashotahensis $\mathrm{n}$. sp.; from marl beds, Waukeshaw County, Wisconsin].-Nautilus, vol. 23, pp. 19-21, June, 1909.

Baker, M. B.

52. Lake Abitibi area [Ontario].-Ontario, Bur. Mines, 18th Ann. Rept., vol. 18, pt. 1, pp. 263-283, 9 figs., 1909.

Describes the geology of the area, and the occurrence of gold and iron.

53. Our visible supply of brick.-Canadian Min. Jour., vol. 30., pp. 100-102, February $15,1909$.

Gives an account of the clays of Ontario.

54. [Clays of Ontario.]-Canadian Min. Jour., vol. 30, pp. 244-245, April 15, 1909. Discusses the nomenclature and source of clays in Ontario. 
Balarezo, Manuel.

55. Breve reseña sobre las minas de plata y cobre, de nuestro pais.-Soc. Geol. Mexicana, Bol., t. 5, pp. 7-8, 133-145, 1909.

Gives a summarized account of the silver and copper deposits of Mexico, with regard to geographic distribution, geologic occurrence, and types of deposits.

56. Los yacimientos metaliferos de El Dorado (Tepic).--Soc. Geol. Mexicana, Bol., t. 6, pp. v-vi, 1-4, 1909.

Gives a brief account of ore-bearing deposits at El Dorado, Territory of Tepic, Mexico.

Ball, Max W.

57. The western part of the Little Snake River coal field, Wyoming.-U. S. Geol. Survey, Bull. 341, pp. 243-255, 1 pl. (map), 1909.

Describes the geography, stratigraphy, and structure of the field and the physical properties and composition of the coals.

Ball, S. Mays.

58. Manganese deposits of Virginia.-Eng. and Min. Jour., vol. 87, p. 1056, May 22, 1909.

59. T'in deposits of the Carolinas.-Eng. and Min. Jour., vol. 87, pp. 1139-11.40, June 5, 1909.

60. Review of fossil iron-ore deposits of Georgia.-Eng. and Min. Jour., vol. 88, pp. 200-204, 3 figs., July 3l, 1.909.

Ball, W. G.

The lead-silver deposits at Newburyport, Massachusetts, and their accompanying contact zones.-See Clapp and Ball, no. 229.

\section{Bancroft, George J.}

61. The formation and enrichment of ore-bearing veins.-Am. Inst. Min. Eng., Bull., no. 31, pp. 581-589, July, 1909.

62. Formation and enrichment of ore-bearing veins.-Min. World, vol. 31, pp. 177179, July 17, 1909.

Barbour, Percy E.

63. The Los Angeles oil industry.-Eng. and Min. Jour., vol. 88, pp. 365-366, August 21, 1909.

Includes notes on the occurrence of petroleum in the Los Angeles field, California.

Barlow, Alfred E.

64. Report on mining claims in the Montreal River mining division.-Canadian Min. Jour., vol. 30, pp. 51-54, 1 fig., January 15, 1909.

Describes the geology of the district and the occurrence of the silver ores.

65. Mineral veins in the Montreal River district.-Canadian Min. Jour., vol. $36, p p$. 57-58, 77, January 15 and February 1, 1909.

The nepheline and associated alkali syenites of eastern Ontario.-See Adams and Barlow, no. 4.

Barnett, V. H.

The stratigraphic and faunal relations of the Waldron fauna in soutleern Indiana.-See Kindle and Barnett, no. 670.

Baron, H. J.

66. Rio Plata mine and mill, western Chihuahua, Mexico.-Eng. and Min. Juur., vol. 87, pp. 147-151, 6 figs., January 16, 19009. .

- Includes notes on the occurrence of the silver ores.

67. Mines and works of the Rio Tinto Copper Company [Terrazas, Chihuahua, Mexico].-Min. World, vol. 31, pp. 681-684, 2 figs., October 2, 1909.

Includés notes on the local geology and the occurrence and character of the copper ores, 
Barrell, Joseph.

68. Some distinctions between marine and terrestrial conglomerates.-Abstract: Science, new ser., vol. 29, p. 624, April 16, 1909.

Barry, John G.

69. The Bottineau gas field.-North Dakota Geol. Survey, 5th Bienn. Rept., pp. 245-251, 1 pl., 1908.

Describes the occurrence of natural gas in Bottineau County and prospecting in the field.

Barry, John G., and Melsted, V. J.

70. The geology of northeastern North Dakota with special reference to cement materials.-North Dakota Geol. Survey, 5th Bienn. Rept., pp. 115-211, 10 pls., 1908.

Bartow, Edward:

71. Classification of waters according to physical and chemical properties.Illinois State Geol. Survey', Bull. no. 10, pp. 22-55, 8 figs., 1909.

Bartow, Edward, and others.

72. The mineral content of Illinois waters.-Illinois State Geol. Survey, Bull. no. 10, 192 pp., 10 figs., 1909.

Bascom, Florence.

73. The pre-Cambrian gneisses of the Pennsylvania Piedmont Plateau.-Abstract: Science, new ser., vol. 30, p. 415, September 24, 1909.

Describes the occurrence and relations of the several pre-Cambrian gneisses.

Bascom, Florence, and others.

74. Description of the Philadelphia district.-U. S. Geol. Survey, Geol. Atlas U. S., Philadelphia folio (no: 162), 23 pp., 12 pls. (sections, maps, and illustrations), 1909.

Describes the general physical features, the general geology and geologic structure, the distribution, character, and relations of pre-Cambrian, Cambrian, Ordovician, Triassic, Cretaceous, Tertiary, and Quaternary formations, and pre-Cambrian and Triassic igneous rocks, the geologic and physiographic history, and the mineral resources.

75. Description of the Trenton quadrangle, New Jersey-Pennsylvania.-U. S. Geol. Survey, Geol. Atlas U. S., Trenton folio (no. 167), library edition, 24 pp., 4 pls. (3 maps and sections sheet), 3 figs., field edition, 185 pp., 3 folded maps and sections, 3 figs., 1909.

Describes the geography and topography, the occurrence, character, and relations of pre-Cambrian, Cambrian, Triassic, Cretaceous, Tertiary, and Quaternary formations, and of igneous rocks, the structural features, the geologic history, and the economic resources.

Baskerville, Charles.

76. The rare metals.-Eng. and Min. Jour., vol. 87, pp. 10-11, 203, 257-258, 518-519, $548,1909$.

Describes thecharacters and occurrence of minerals containing the rare metals titanium, tungsten, uranium, vanadium, zirconium.

77. Economic possibilities of American oil shales.-Eng. and Min. Jour., vol. 88, pp. 149-154, 195-199, 6 figs., July 24 and 31, 1909.

Includes notes on the geology of oil-bearing shales of New Brunswick.

Bassler, Ray S.

78. The cement resources of Virginia west of the Blue Ridge--Virginia Geol. Survey, Bull. no. 2A, 309 pp., 30 pls., 30 figs., 1909.

Describes the general geology of northwestern, western, and southwestern Virginia, the distribution, characters, and relations of Cambrian, Ordovician, and later Paleozoic formations with particular reference to cement materials, and the geology and cement materials of individual counties. Includes illustrations of characteristic fossils. 
Bassler, Ray S.-Continued.

79. Dendroid graptolites of the Niagaran dolomites at Hamilton, Ontario.-U. S. Nat. Mus., Bull. 65, 76. pp., 5 pls., 91 figs., 1909.

80. The Nettleroth collection of invertebrate fossils.-Smithsonian Misc. Coll., vol. 52 (Quart. Issue, vol. 5, pt. 2), pp. 121-152, 3 pls., 1909.

Includes notes on the stratigraphy of Louisville, $\mathrm{Ky}$., and vicinity, a brief biography of Henry Nettleroth (with portrait), and a list of the types obtained from the Nettleroth collection.

81. Some noteworthy accessions to the Division of Invertebrate Paleontology in the National Museum.--Smithsonian Misc. Coll., vol. 52 (Quart. Issue, vol. 5, pt. 2), pp. 267-269, 2 pls., 1909.

Describes a slab containing Uintacrinus socialis from Kansas and other paleontologic accessions.

Bastin, Edson S.

82. Chemical composition as a criterion in identifying metamorphosed sediments.Jour. Geology, vol. 17, no. 5, pp. 445-472, 1909. Abstract: Science, new ser., vol. 29, pp. 631-632, April 16, 1909; pp. 948-949, June 11, 1909.

Mineral resources of the United States, 1908: Graphite; quartz and feldspar.See no. 1170.

Bastin, Edson S., and Davis, Charles A.

83. Peat deposits of Maine.-U. S. Geol. Survey, Bull. 376, 127 pp., 3 pls., 20 figs., 1909.

Bather, F. A.

84. Visit to the Florissant exhibit in the British Museum (Natural History).Geologists' Assoc., London, Proc., vol. 21, pt. 3, pp. 159-165, 1909.

0

Describes the Miocene beds at Florissant, Colo., and the conditions under which they were deposited, and gives a list of papers relating to the Florissant fossils, published after 1905.

Baumhauer, $\mathrm{H}$.

85. Ueber die Winkelverhältnisse des Benitoit.-Centralbl. Mineral., Geol., und Paläont., Jg. 1909, no 19, pp. 592-594, 1909.

Describes measurements of the crystals of benitoite.

Bayley, William Shirley.

86. Preliminary account of the geology of the Highlands in New Jersey.--Univ. Illinois Bull., vol. 6, no. 17, The University Studies, vol. 3, no. 2, pp. 5-19, January, 1909.

Describes the occurrence and relations of pre-Cambrian sedimentary and gneissic rocks, structural features of the Highland area, and the magnetite deposits.

87. Records of deep wells in southern Maine.-U. S. Geol. Survey, Water-Supply Becke, F. Paper no. 223, pp. 238-257, 1909:

88. Uranpecherz von Kirk mine, Bald Mountain, Gilpin City, Colorado.-Tschermaks Mineral. und Petrogr. Mitt., N. F., Bd. 28, p. 188, 1909.

A.note upon uranium ore and associated minerals from Bald Mountain, Colorado.

Becker, George F.

89. Relations between local magnetic disturbances and the genesis of petroleum.U. S. Geol. Survey, Bull. 401, 24 pp., 1 pl., 1909.

Beede, Joshua W.

90. Formations of the Marion stage of the Kansas Permian.-Kansas Acad. Sci., Trans., vol. 22, pp. 248-256, 2 figs., 1909.

Describes the occurrence, characters, and relations of the formations in Kansas and adjacent parts of Oklahoma.

$56693^{\circ}-$ Bull. $444-10 \_-2$ 
Beede, Joshua W.-Continued.

91. The bearing of the stratigraphic history and invertebrate fossils on the age of the anthracolithic rocks of Kansas and Oklahoma.-Jour. Geology, vol. 17, no. 8, pp. 710-729, 1 fig., 1909.

92. Review of The Guadalupian fauna, by George H. Girty.-Jour. Geology, vol. 17, no. 7, pp. 672-679, 1909.

93. Relationships of the Pennsylvanian and Permian faunas of Kansas and their correlation with similar faunas of the Urals.-Abstract: Science, new ser., vol. 29, pp. 637-638, April 16, 1909.

94. The invertebrate faunas and correlation of some so-called Permian rocks of the Mississippi Valley, with remarks on their stratigraphy.-Abstract: Science, new ser., vol. 29, p. 752, May 7, 1909.

Beede, Joshua W., and Rogers, Austin F.

95. Coal measures faunal studies: Faunal divisions of the Kansas coal measures.Kansas, Univ. Geol. Survey, vol. 9', pp. 318-385, 1 pl., 1908.

Discusses the nomenclature, the correlation value of species, the faunal distribution by horizons, including a chart, and the faunal characteristics of the various stages in to which the coal measures are divided.

Bennett, John.

History of geological fieldwork in Kansas.--See Haworth and Bennett, no. 51.7. General stratigraphy of Kansas.-See Haworth and Bennett, no. 518.

Berg, G.

96. Ueber krystalline Schiefer aus dem Las Animas Canyon südlich von Silverton, Colorado.-Tschermaks Mineral. und Petrogr. Mitt., N. F., Bd. 27, pp. 276-284, 1 fig., 1908.

Describes crystalline slates in Las Animas Canyon south of Silverton, Colo.

Bergeat, Alfred.

97. Der Granođdiorit von Concepción del Oro im Staate Zacatecas (Mexiko) und seine Kontaktbildungen.-Neues Jahrb., Beilage-Band 28, Heft 3, pp. 421-573, 20 pls., 13 figs., 1909.

Describes the geologic relations and the petrographic-chemical properties of a granodiorite mass in the State of Zacatecas, Mexico, and the contact phenomena.

98. Nontronit, gebildet durch die Einwirkung von Eisensulfatlösung auf Wollastonit.-Centralbl. Mineral., Geol., und Paläont., Jg. 1909, no. 6, pp. 161-168, 1909.

Describes nontronite from Concepcion del Oro, Mexico, produced by the action of iron sulphate in solution upon wollastonite.

Berkey, Charles P.

99. Some geological features of the vicinity of Franconia, Minnesota.-Abstract: Minnesota Acad. Sci., Bull., vol. 4, no. 2, p. 194, 1906.

100. Origin and distribution of Minnesota clays.-Abstract: Minnesota Acad. Sci., Bull., vol. 4, no. 2, pp. 241-242, 1906.

The paper in full has been published in the American Geologist, vol. 29, pp. 171-177, 1902.

101. Areal and structural geology of southern Manhattan Island.-New York Acad. Sci., Annals, vol. 19, pp. 247-282, 2 pls., 1909.

102. A summary of an investigation into the structural geology of southern Manhattan and the condition of the East River channel.-Abstract: Science, new ser., vol. 29, pp. 279-280, February 12, 1909.

103. Characteristics of the older crystallines of southeastern New York.-Abstract: Science, new ser., vol. 30, p. 416, September 24, 1909.

Gives characters by which the formations can be discriminated and notes upon their distribution. 
Berry, Edward W.

104. A Miocene flora from the Virginia coastal plain.-Jour. Geology, vol. 17, no. 1, pp. 19-30, 11 figs., 1909.

105. Contributions to the Mesozoic flora of the Atlantic coastal plain: III. New Jersey.-Torrey Botanical Club, Bull., vol. 36, no. 5, pp. 245-264, 2 pls., May, 1909.

Describes and renames Cretaceous plants from the Raritan formation of New Jersey.

106. Juglandaceæ from the Pleistocene of Maryland.-Torreya, vol. 9, no. 5, pp. 96-99, 6 figs., May, 1909.

107. Additions to the Pleistocene flora of North Carolina.-Torreya, vol. 9, no. 4, pp. 71-73, 2 figs., April, 1909.

108. Pleistocene swamp deposits in Virginia.-Am. Naturalist, vol. 43, pp. 432436, 2 figs., July, 1909.

Gives notes upon the distribution, in Pleistocene times and later, of various plants, and upon the occurrence of Pleistocene swamp deposits, and remarks upon several additions to the known Pleistocene flora of Virginia.

109. The geologic relations of the Cretaceous floras of Virginia and North Carolina.-Abstract: Science, new ser., vol. 29, p. 629, April 16, 1909.

Beyer, Samuel Walker.

110. Mineral production in Iowa in 1908.-Iowa Geol. Survey, vol. 19, pp. 1-20, 1909.

111. Coal statistics [Iowa]--Iowa Geol. Survey, vol. 19, pp. 591-597, 1 pl. (map), 1 fig., 1909.

112. Peat deposits in Iowa.-Iowa Geol. Survey, vol. 19, pp. 689-730, 1909.

Bibbins, Arthur Barneveld.

113. Occurrence of the Magothy formation on the Atlantic islands.-Abstract, Science, new ser., vol. 29, p. 634, April 16, 1909.

Bigot, Raoul.

114. Prospection pour cuivre au sud de l'État de Michoacan, Mexique.-Soc. Ing. Civils de France, Mém., $6^{\text {e }}$ ser., no. 5, pp. 843-873, 1 pl. (map), 5 figs., 1908. Soc. cient. "Antonio Alzate," Rev. cient. y Biblio., t. 25, nos. 2-12, pp. 9-40, 2 pls. (maps), 4 figs., 1908.

Describes prospecting for copper in the State of Michoacan, Mexico.

Birge, E. A.

115. Report of the director of the Survey.-Wisconsin Geol. and Nat. Hist. Survey, Sixth Bienn. Rept. Comm., pp. 9-33, 1908.

An administrative report.

Blackwelder, Eliot.

116. The valuation of unconformities.-Jour. Geology, vol. 17, no. 3, pp. 289-299, 4 figs., 1909.

117. Cenozoic history of the Laramie region, Wyoming.-Jour. Geology, vol. 17, no. 5, pp. 429-444, 7 figs., 1909.

118. The Yakutat coastal plain of Alaska; a combined terrestrial and marine formation.-Am. Jour. Sci., 4th ser., vol. 27, pp. 459-466, 3 figs., June, 1909.

Describes the physical characteristics of the formation and the character and distribution of the sediments of which it is formed.

Blake, William P.

119. Minerals of Arizona; their occurrence and association, with notes on their composition. A report to the Governor of Arizona. Tucson; 1909. 64 pp. 
Blake, William P.-Continued.

120. Geological sketch of the region of Tucson, Arizona. In MacDougal, D. T., Botanical features of North American deserts (Publ. no. 99 of the Carnegie Institution of Washington), pp. 45-68, 1 pl. (map), 1908.

Blatchley, Raymond S.

121. The mineral production of Illinois in 1908.-Illinois State Geol. Survey, Circular no. 5, 20 pp., June, 1909.

122. Drilling for oil in eastern Illinois.-Min. and Sci. Press, vol. 99, pp. 613-617, 3 figs., November 6, 1909.

Includes data in regard to the Illinois oil pools.

Bogdanovich, $\mathrm{K}$.

123. Earthquakes of Messina and San Francisco. [In Russian]. St. Petersburg, 1909. 160 pp.; 84 figs.

Böggild, O. B.

124. The minerals from the basalt of east Greenland.-Meddelelser om Grönland, H. 28, pp. 97-129, 11 figs., 1909.

Describes the occurrence and crystallographic characters.

Bordeaux, Albert F. J.

125. Geological formation of Mexico's silver mines.-Min. World, vol. 31, pp. 911., 1 fig., July 3, 1.909.

A review of the silver deposits of Mexico in their geologic relations.

The silver mines of Mexico.-Am. Inst. Min. Eng., Trans., vol. 39, pp. 357368,1909 . See no. 115 of the bibliography for 1908, U. S. Geol. Survey, Bull. 409, p. 17.

Böse, Emilio.

126. Noticia preliminar sobre la fauna pliocénica de Tuxtepec, Oaxaca, México.Soc. Geol. Mexicana, Bol., t. 1, pp. 139-149, 1905.

A preliminary notice of a Pliocene fauna from Tuxtepec, Oaxaca, Mexico, describing occurrence and character of fauna and giving a list of species identified.

127. Zur Frage der Entstehung des sogenannten mexikanischen Zentralplateaus.Neues Jahrb., Jg. 1908, Bd. 2, Heft 3, pp. 114-135, 2 pls., 6 figs., February, 1909.

Discusses the origin and structure of the so-called central plateau of Mexico.

128. Ueber eine durch vulkanischen Druck entstandene Faltungszone im Tal von Mexiko.-Neues Jahrb., Jg. 1909, Bd. 1, Heft 1, pp. 28-42, 1909.

Discusses the origin of fault-zones through volcanic forces with particular reference to the valley of Mexico.

Botsford, C. W.

129. Geology of the Guanajuato district, Mexico.-Eng. and Min. Jour., vol. 87, pp. 691-694, 1 fig., April 3, 1909.

Gives a general account of the geology and notes on the ore deposits.

130. The Zacatecas district and its relation to Guanajuato and other camps.-Eng. and Min. Jour., vol. 87, pp. 1227-1228, 2 figs., June 19, 1909.

Gives an account of the geology of the district and its relations to that of Guanajuato and other localities in Mexico.

Bowles, O.

131. Pyromorphite from British Columbia, Canada.-Am. Jour. Sci., 4th ser., vol. 28, pp. 40-44, 1 fig., July, 1909.

Bownocker, John Adams.

132. Geology as applied to the formations in which natural gas is found in the Appalachian regions.-Progressive Age, vol. 27, pp. 541-544, July 1, 1909. 
Bradford, A. H., and Curtis, Roy $\mathrm{P}$.

133. Dredging at Breckenridge, Colorado.--Min, and Sci. Press, vol. 99, pp. 361-366, 4 figs., September 11, 1909.

Includes notes on the local geology and the occurrence of placer gold.

Bradford, Robert $\mathrm{H}$.

134. Some Utah mineral deposits and their metallurgical treatment.-Am. Min. Congress, 11th Ann. Sess., Papers and Addresses, pp. 101-118, 1909.

Bradley, W. M.

135. On the analysis of the mineral neptunite from San Benito County, California.-Am. Jour. Sci., 4th ser., vol. 28, pp. 15-16, July, 1909. Zeitschr. Krystal. und Mineral., Bd. 46, Heft 6, pp. 516-517, 1909.

Branner, John C.

136. Bibliography of the geology of Arkansas.-Arkansas, Geol. Survey, [Rept. on] Slates of Arkansas (Purdue), pp. 97-164, 1909.

137. Some facts and corrections regarding the diamond region of Arkansas.Eng. and Min. Jour., vol. 87, pp. 371-372, February 13, 1909.

Branner, John C., and others.

138. Description of the Santa Cruz quadrangle, California.-U. S. Geol. Survey, Geol. Atlas U. S., Santa Cruz folio (no. 163), 11 pp., 6 pls. (maps, sections, and illustrations), 1909.

Describes the geography, the general character of the rocks, the distribution, character, and relations of Jurassic, Cretaceous, Tertiary, and Quaternary formations, and of igneous rocks, the geologic structure, the geologic history, and the mineral resources.

Branson, E. B.

139. The fauna of the residuary Auburn chert of Lincoln County, Missouri.-St. Louis, Acad. Sci., Trans., vol. 18, no. 4, pp. 39-52, 1 pl., 1909.

Describes new species of Pelecypoda, Gastropoda, and Trilobita from early Ordovician - strata.

140. Notes on some dinichthyids from northern Ohio.-Abstract: Science, new ser., vol. 29, p. 197, January 29, 1909.

Brigham, William $\mathrm{T}$.

141. The volcanoes of Kilauea and Mauna Loa.-Bernice Pauahi Bishop Mus., Mem., vol. 2, no. 4, 222 pp., 28 pls., 143 figs., 1909.

Gives the recorded history of these volcanoes to 1909 .

Brinsmade, Robert B.

142. Lead and zinc fields of southwestern Wisconsin.-Min. Science, vol. 58; pp. 305-307, 324-325, 5 figs., October 15 and 22, 1908.

143. The great iron fields of the Lake Superior district.-Min. Science, vol. 58, pp. 425-427, 444-446, 465-467, 484-485, 505-507, 528-530, 18 figs., 1908; vol. 59, pp. 127-129, 149-151., 304-306, 325-327, 12 figs., 1909.

\section{British Columbia.}

Annual report of the minister of mines for the year ending 31st December, 1908 , being an account of mining operations for gold, coal, etc., in the Province of British Columbia. Victoria, B. C., 1909.-See Robertson, no. 1007.

Brock, Reginald Walter.

144. Summary report of the Geological Survey Branch of the Department of Mines [of Canada] for the calendar year 1908. Ottawa, 1909, $220 \mathrm{pp}$.

Outlines the administrative work and field investigations carried on in 1908. Includes brief reports by various members of the staff. 
Brock, Reginald Walter-Continued.

145. Introduction to a descriptive sketch of the geology and economic minerals of Canada.-Canada, Geol. Survey, Pub. no. 1085, pp. 7-22, 1909.

146. Hugh Fletcher [1848-1909].-Canadian Min. Jour., vol. 30, pp. 677-678, November 15, 1909.

Gives a sketch of his life and a list of his writings on geology.

Brooks, Alfred Hulse.

147. Investigation of mineral resources of Alaska in 1908. Administrative report.U. S. Geol. Survey, Bull. 379, pp. 5-20, 1909.

148. The mining industry in Alaska in 1908.-U. S. Geol. Survey, Bull. 379, pp. 21-62, 1 pl., 1909.

149. Mineral resources of Alaska.--U. S. Geol. Survey, Bull. 394, pp. 172-207, 1 pl., 1.909. Rept. Nat. Conservation Comm. (60th Cong., 2d sess., Sen. Doc. no. 676), vol. 3, pp. 572-603, 1 pl., 1909.

150. Alaska and its mineral resources.-Am. Min. Congress, 11th Ann. Sess., Papers and Proc., pp. 258-268, 1909.

Brooks, Alfred H., and others.

151. Mineral resources of Alaska. Report on progress of investigations in 1908.U. S. Geol. Survey, Bull. 379, 411 pp., 9 pls., 21 figs., 1909.

Brooks, E. W.

152. Geology and mineralogy of London-Arizona mine, Arizona.-Min. Reporter, vol. 56, pp. 117-118, August 8, 1907.

Describes the occurrence and character of copper ores in the Banner mining district, Gila County, A riz.

Brooks, William Keith.

153. Biographical memoir of Alpheus Hyatt, 1838-1902. (Read before the National Academy of Sciences, April 23, 1908.)-Nat. Acad. Sci., Biog. Mem., vol. 6, pp. 311-325, 1 pl. (port.), 1909.

Includes a list of his writings.

Brown, E. Percy.

154. Notes on geological structure at the Richardson mine as shown by the plans and models of the same.-Nova Scotia, Min. Soc., Jour., vol. 13, pp. 17-26, 5 pls., 1909.

Gives notes on the local geology of the Upper Seal Harbour gold district, Guysborough County, Nova Scotia.

Brown, Robert M.

155. The New England geological excursion.-Science, new ser., vol. 30, pp. 591-592, October 29, 1909.

Gives a brief account of the ninth annual intercollegiate geologic excursion. Includes notes upon various geologic features of the region traversed.

Brown, Thomas Clachar.

156. Studies on the morphology and development of certain rugose corals.-New York Acad. Sci., Annals, vol. 19, pt. 1, pp. 45-97, 22 figs., 1909.

Brumell, H. P. H.

157. Occurrence and geology of Canadian graphite.-Min. World, vol. 30, pp. 933-934, May 15, 1909.

Buckley, Ernest Robertson.

158. Geology of the disseminated lead deposits of St. Francois and Washington counties, Missouri.-Missouri Bur. Geology and Mines, vol, 9, pt. 1, 259 pp., 39 pls., 10 figs., pt. 2, pls. 40-121, 1909. 
Buckley, Ernest Robertson-Continued.

159. Discussion of paper by C. R. Keyes, Ozark lead and zinc deposits, their genesis, localization, and migration.-Am. Inst. Min. Eng., Bull., no. 34, pp. 949-954, October, 1909.

160. Lead and zinc mining in the Central States in 1907.-Econ. Geology, vol. 4, no. 2, pp. 175-177, 1909.

Discusses the occurrence of lead and zinc ores in Missouri.

161. Review of The geology and ore deposits of the Cœur d'Alene district, Idaho, - by F. L. Ransome and F. C. Calkins (U. S. Geol. Survey, Prof. Paper 62).-Econ. Geology, vol. 4, no. 2, pp. 178-186, 1909.

Buehler, H. A.

162. Biennial report of the state geologist transmitted by the board of managers of board of geology and mines to the forty-fifth general assembly.-Missouri Bur. Geology and Mines, 59 pp. [1909].

An administrative report, but includes a chapter on the mineral resources of Missouri.

\section{Burchard, Ernest F.}

163. Tonnage estimates of Clinton iron ore in the Chattanooga region of Tennesse€, Georgia, and Alabama.-U. S. Geol. Survey, Bull. 380, pp. 169-187, 1909.

164. Clinton iron ores in the Birmingham district, Alabama.-Abstract: Science, new ser., vol. 29, pp. 557-558, April 2, 1909.

165. Fluorspar in Colorado.-Min. and Sci. Press, vol. 99, pp. 258-261, August 21, 1909.

Mineral resources of the United States, 1908: Fluorspar and cryolite; gypsum; barytes and strontium; mineral paints.-See no. 1170.

Burckhardt, Carlos, and Villarello, J. D.

166. Estudio geológicọ de los alrededores de una parte del Río Nazas en relación con el proyecto de una presa en el cañón de Fernández.-Mexico, Inst. Geol., Parerg., t. 3, no. 2, pp. 117, 135, 9 pls., 1909.

Describes the geology along the river Nazas, in the State of Durango, Mexico.

Burgess, J. A.

167. The geology of the producing part of the Tonopah mining district [Nevada].Econ. Geology, vol. 4, no. 8, pp. 681-712, 11 figs., 1909.

Burling, Leander D.

168. The landslide at Frank, Alberta.-Abstract: Science, new ser., vol. 29, pp. 947-948, June 11, 1909.

Burrows, A. G.

169. The Gowganda and Miller lakes silver area.-Ontario, Bur. Mines, 18th Ann. Rept., 1908, vol. 18, pt. 2, pp. 1-20, 20 figs., 3 maps, 1909. Abstract: Min. World, vol. 31, pp. 181-183, 1 fig., July 17, 1909.

Describes the geology of the area and the mining operations.

170. The South Lorraine silver area.-Ontario Bur. Mines, 18th Ann. Rept., 1908, pt. 2, pp. 21-31, 8 figs., 1909.

Burrows, R. H.

171. Geology of northern Mexico.-Min. and Sci. Press, vol. 99, pp. 290-294, 324-327, 8 figs., 1909.

Bustamante, Miguel.

172. Climas de los tiempos geologicos y la división en eras (trabajo leído el 19 de octubre'de 1906 en la Sociedad Geológica Mexicana). Mexico, 1906. $28 \mathrm{pp}$.

Discusses climate in geologic time and the division into eras.

173. Critica y teorias nuevas sobre el periodo carbonifero.-Mexico, 1909. $39 \mathrm{pp}$. 
Butler, Bert S.

174. The Yakutat Bay region, Alaska; petrographic study of rocks.-U. S. Geol. Survey, Prof. Paper 64, pp. 171-178, 1909.

175. Pyrogenetic epidote.-Am. Jour. Sci., 4th ser., vol. 28, pp. 27-32, July, 1909.

Reviews occurrences previously reported, describes an occurrence in Shasta County, Cal., and the evidence for its primary origin.

Mineral resources of the United States, 1908: Copper.-See no. 1170.

The Yakutat Bay region, Alaska.-See Tarr and Butler, no. 1137.

The Yakutat Bay region, Alaska; areal geology.-See Tarr. and Butler, no. 1138.

Butler, G. Montague.

176. An outline for the examination of mines from a geological standpoint.Min. Science, vol. 60, pp. 461-463, Noviember 18, 1909.

Butts, Charles.

177. Ganister in Blair County, Pennsylvania.-U. S. Geol. Survey, Bull. 380, pp. 337-342, 1909.

Describes the geologic occurrence and relations, methods of exploitation and manufacture, and qualities of the products.

Caine, Thomas A., and others.

178. Soil survey of the Middlebourne area, West Virginia (Marshall, Wetzel, and Tyler counties).-West Virginia Geol. Survey, County Reports, Marshall, Wetzel, and Tyler counties, pp. 599-635, 1 map, 1909.

Cairnes, D. D.

179. Preliminary report on a portion of the Yukon Territory, west of the Lewes River and between the latitudes of Whitehorse and Tantalus.-Canada Geol. Survey, Summ. Rept., 1908, pp. 26-32, 1909: Abstract: Min. and Sci. Press, vol. 99, pp. 29-30, 1909.

Includes notes on the general geology and the occurrence and character of coal deposits and copper and other ores.

Caldwell, M. M.

180. Lead and zinc ores of Virginia.-Mines and Minerals, vol. 30, pp. 269-270, December, 1909.

Calkins, Frank Cathcart.

181. A geological reconnaissance in northern Idaho and northwestern Montana.U. S. Geol. Survey, Bull. 384, pp. 7-91, 2 pls., 3 figs., 1909.

Describes the physiographic features of the region, the occurrence, character, and relations of Algonkian and igneous rocks, and the geologic structure.

182. Geology and ore deposits of the Cœur d'Alene district. Discussion of review by E. R. Buckley.-Econ. Geology, vol. 4, no. 3, pp. 258-261, 1909.

183. Primary scapolite in igneous rocks.-Abstract: Science, new ser., vol. 29, pp. 946-947, June 11, 1909.

Calvert, W: R.

184. The Lewistown coal field, Montana.-U. S. Geol. Survey, Bull. 341, pp. 108122, 1 pl. (map), 1909.

Describes the topography, stratigraphy, and structure of the field, the occurrence and character of the coal beds, the character of the coal, and the mining development.

185. Geology of the Lewistown coal field, Montana.-U. S. Geol. Survey, Bull. 390, 83 pp., 5 pls., 1 fig., 1909.

Describes the geography and geologic structure of the field, the occurrence, character, and relations of Carboniferous, Jurassic, Cretaceous, and Quaternary formations, the distribution and character of the coal beds, and the quality of the coal. 
Calvin, Samuel.

186. Geology and revelation. An address delivered before the members of the Okoboji Lakeside Laboratory on Sunday, the Fourth of July, 1909. Privately printed for the students of the Lakeside Laboratory, 1909. $27 \mathrm{pp}$., $1 \mathrm{pl}$. (port. of the author).

187. Present phase of the Pleistocene problem in Iowa.-Geol. Soc. America, Bull., vol. 20, pp. 133-152, 5 pls., March, 1909.

Describes the various drift sheets and interglacial deposits, and their relations.

188. Aftonian mammalian fauna.-Geol. Soc. America, Bull., vol. 20, pp. 341-356, 12 pls., 1909.

189. Seventeenth annual report of the state geologist, 1908.-Iowa Geol. Survey, vol. 19, pp. xi-xiv, 1 pl. (map), 1909. .

An administrative report. The map shows the progress of detailed mapping in 1908.

Campbell, Marius R.

190. Contributions to economic geology, 1907, Part. II. Coal and lignite. Introduction.-U. S. Geol. Survey, Bull, 341, pp. 5-14, 1 pl. (map), 1909.

Outlines the work in 1907 of the United States Cieological Survey in the investigation of the coal areas of the United States.

Campbell, Marius R., and Parker, Edward W.

191. Coal fields of the United States.-U. S. Geol. Survey, Bull. 394, pp. 7-26, 1 pl., 1 fig., 1909. Rept. Nat. Conservation Comm. (60th Cong., 2d sess., Sen. Doc. no. 676), vol. 3, pp. 426-442, 1 pl., 1 fig., 1909. Am. Inst. Min. Eng., Bull., no. 28, pp. 365-372, A pril, 1909.

Campbell, William.

192. The microstructure of a complex ore from the Frisco mine, Gem, Idaho.Eng. and Min. Jour., vol, 87, pp. 260-261, 8 figs., January 30, 1909.

Camsell, Charles.

193. Osoyoos and Similkameen mining divisions [British Columbia].-Canada Geol. Survey, Summ. Rept., 1908, pp. 61-64, 1909. British Columbia, Ann. Rept. Minister of Mines, for 1908, pp. 135-139, 1909.

Gives notes upon the geology and describes the mining developments.

Canada, Department of Mines, Mines Branch.

194. Annual report on the mineral production of Canada during the calendar year 1906. Ottawa, 1909. $182 \mathrm{pp}$.

\section{Canada, Geological Survey.}

195. Catalogue of publications of the Geological Survey, Canada (Revised to January 1,1909$)$. Ottawa, 1909. $181 \mathrm{pp}$.

Summary report of the Geological Survey Branch of the Department of Mines for the calendar year 1908.-See Brock, R. W., no. 144.

Capps, Stephen R., jr.

196. Pleistocene geology of the Leadville quadrangle, Colorado.-U. S. Geol. Survey, Bull. 386, 99 pp., 8 pls., 13 figs., 1909. Abstract: Science, new ser., vol. 29, p. 946, June 11, 1909.

197. Rock glaciers in Alaska.-Abstract: Science, new ser., vol. 30 , p. 974 , December 31, 1909.

Describes the occurrence and character of rock glaciers and distinguishes them from true glaciers.

Carman, J. Ernest.

198. The Mississippi Valley between Savanna and Davenport.-Illinois State Geol. Survey, Bull. no. 13, 96 pp., 23 pls., 26 figs., 1909.

Gives an account of the bed-rock geology with particular reference to the development of existing physiographic features, and describes these features and their origin. 
Carney, Frank.

199. State geological survey reports on limited areas.-School Science and Mathematics, vol. 8, pp. 475-482, June, 1908.

200. A stratigraphical study of Mary Ann township, Licking County, Ohio.Denison Univ., Sci. Lab., Bull., vol. 14, pp. 127-155, 15 figs., 1909.

201. The development of the idea of glacial erosion in America.-Denison Univ., Sci. Lab., Bull., vol. 14, pp. 199-208, June, 1909.

An historical review of contributions to the subject of glacial erosion made by various writers.

202. The raised beaches of the Berea, Cleveland, and Euclid sheets, Ohio.Denison Univ., Sci. Lab., Bull., vol. 14, pp. 262-287, 5 figs., June, 1909.

203. Pleistocene geology of the Moravia quadrangle, New York.-Denison Univ., Sci. Lab., Bull., vol. 14, pp. 335-442, 27 figs., 1. map, November, 1909.

204. The metamorphism of glacial deposits.-Jour. Geology, vol. 17, no. 5, pp. 473-487, 7 figs., 1909. Abstract: Science, new ser., vol. 29, pp. 750-751, May 7, 1909.

205. Glacial erosion on Kelley's Island, Ohio.-Abstract: Science, new ser., vol. 29, p. 629, April 16, 1909.

Carpenter, M. H.

206. Notes on the mineral zone of Zacualpam in the states of Mexico and Guerrero, Mexico.-Mexican Min. Jour., vol. 9, no. 5, pp. 24-25, November, 1909.

Carpenter, Philip P.

On the Pleistocene fossils collected by Col. E. Jewett at Santa Barbara, Cal., with descriptions of new species (reprinted from Ann. and Mag. Nat. Hist., 3d ser., vol. 17, pp. 274-278, 1866).-U. S. Ceol. Survey, Prof. Paper 59, pp. 189-191, 1909.

Carr, Henry C.

207. Vein structure in the Monument mine.-Min. and Sci. Press, vol. 98, pp. 557-558, 1 fig., April 17, 1909.

Includes notes on the local geology and the character and occurrence of the ores in the Salmon River Mountains, Lemhi County, Idaho.

Carter, Oscar C. S.

208. Earthquakes in the light of the new seismology.-Franklin Inst., Jour., vol. 167, no. 6, pp. 434-472, 11 figs., June, 1909.

209. The interior of the earth in the light of the new seismology.-Franklin Inst., Jour., vol. 168, pp. 303-310, 1. fig., October, 1909.

Case, Ermine C.

210. Notes on a collecting trip in the Permian of Texas, during the summer of 1908.-Abstract: Science, new ser., vol. 29, p. 195, January 29, 1909.

Discusses the stratigraphy and mode of deposition of the red beds.

211. American paleontology and neo-Lamarckism.-Michigan Acad. Sci., 11th Report, pp. 18-23, 1909.

Castro, Carlos.

212. Analisis y estudio de una kaolinita encontrada en un carbon de Villafuente, Estado de Coahuila.-Soc. Geol. Mexicana, Bol., t. 5, pp. 10, 147-150, 1909.

Describes an analysis of kaolin in coal from Villafuente, State of Coahuila, Mexico, and explains its origin.

Chamberlin, Rollin Thomas.

213. The gases in rocks.-Jour. Geology, vol. 17, no. 6, pp. 534-568, 1909. 
Chamberlin, Thomas Chrowder.

214. The former rates of the earth's rotation and their bearings on its deformation. In The tidal and other problems, published by the Carnegie Institution of Washington, pp. 3-59, 6 figs., 1909.

215. Soil wastage.-Proceedings of a conference of governors in the White House, Washington, D. C., May 13-15, 1908, Washington, Government Printing Office, 1909, pp. 75-83.

216. Diastrophism as the ultimate basis of correlation.-Jour. Geology, vol. 17, no. 8 , pp. 685-693, 1909.

217. A geologic forecast of the future opportunities of our race.-Science, new ser., vol. 30, pp. 937-949, December 31, 1909.

Chamberlin, T. C., and others.

218. The tidal and other problems. Contributions to cosmogony and the fundamental problems of geology. Published by the Carnegie Institution of Washington, 1909. $264 \mathrm{pp}$.

Chambers, R. E., and Chambers, A. R.

219. Sinking of Wabana submarine slopes.-Canadian Min. Jour., vol. 30, pp. 110-114, 3 pls., 1 fig., February 15, 1909.

Includes notes on the geologic occurrence of the iron ores and a geological section of the ore-bearing strata of Wabana, Newfoundland.

Chance, H. M.

A new theory of the genesis of brown hematite ores; and a new source of sulphur supply.-Am. Inst. Min. Eng., Trans., vol. 39, pp. 522-539, 2 figs., 1909. See no. 199 of the bibliography for 1908, U. S. Geol. Survey, Bull. 409, p. 23 .

Chase, Edwin E.

220. Ore shoots in Nevada.-Econ. Geology, vol. 4, no. 2, pp. 173-174, 1 fig., 1909.

Chase, Thorington.

221. Concepcion del Oro district, State of Zacatecas, Mexico.-Min. World, vol. 31, p. 1068, November 27, 1909.

Includes notes on the geology of the district and the occurrence of the ores.

222. Theory of volcanic action and ore deposition.-Min. and Sci. Press, vol. 99, p. 794, December 11, 1909.

Cirkel, Fritz.

223. Report on the iron-ore deposits along the Ottawa (Quebec side) and Gatineau rivers.-Canada, Dept. Mines, Mines Branch, 147 pp., 5 pls., 15 figs., 2 maps, 1909.

224. Report on the chrome iron-ore deposits in the eastern townships, Province of Quebec.-Canada, Dept. Mines, Mines Branch, 141 pp., 9 pls., 14 figs., 1909.

Discusses the geologic occurrence of the mineral in Canada and other countries, the shape and structure of the ore bodies, the composition of the ores, and their properties and metallurgy.

225. The Opasatika Lake district, Province of Quebec.-Eng. and Min. Jour., vol. $87,-$ pp. 455-456, 2 figs., February 27, 1909.

Gives notes upon the geology of the district and the occurrence of copper ores.

226. Depth of asbestos deposits.-Canadian Min. Jour., vol. 30, pp. 132-135, 4 figs., March 1, 1909. Min. World, vol. 30, pp. 435-437, 4 figs., March 6, 1909. 
Cist, Jacob.

227. Account of the mines of anthracite in the region about Wilkesbarre, Pennsylvania.-Wyoming Hist. and Geol. Soc., Proc. and Coll., vol. 10, pp. 98-114, 1909.

“From Silliman's American Journal of Science, vol. 4, 1832," pp. 1-16. Includes sections showing the position and relations of anthracite coal seams.

Clapp, Charles H.

228. 'Southeastern portion of Vancouver Island.-Canada Geol. Survey, Summ. Rept., 1908, pp. 52-60, 1909. British Columbia, Ann. Rept. Minister of Mines, for 1908, pp. 158-166, 1909.

Describes the general geology and the mineral occurrences.

Clapp, Charles H., and Ball, W. G.

229. The lead-silver deposits at Newburyport, Massachusetts, and their accompanying contact zones.-Econ. Geology, vol, 4, no. 3, pp. 239-250, 1909.

Describes the history of the discovery and development, the general geology, and the mineralogy of the deposits.

- Clapp, Frederick G.

230. Undergwound waters of southern Maine; with records of deep wells, by W. S. Bayley.-U. S. Geol. Survey, Water-Supply Paper 223, 268 pp., 24 pls., 4 figs., 1909.

231. Studies in the application of the anticlinal theory of oil and gas accumulation.-Econ. Geology, vol. 4, no. 6, pp. 565-570, 1909.

232. Influence of geological structure on the occurrence of oil and gas.-Abstract: Science, new ser., vol. 29, p. 440, March 12, 1909.

233. Underground water in crystalline rocks.-Engineering Record, vol. 60, no. 19, pp. 525-527, 3 figs., November 6, 1909.

A preliminary report on the geology of Florida with special reference to the stratigraphy.-See Matson and Clapp, no. 829.

Clark, B. W.

Laboratory manual in physical geography.-See Hopkins and Clark; no. 590.

Clark, George Archibald.

The Bogoslofs.-See Jordan and Clark, no. 63\%.

Clark, William Bullock.

234. Report on the Maryland geological survey.-Johns Hopkins Univ. Circ., no. 1, 1907, pp. 99-101, 1907.

An administrative report.

235. Report on the Maryland geological survey.-Johns Hopkins Univ. Circ.; no.

1, 1908, pp. 90-92, 1908.

An administrative report.

236. Report on the Maryland geological survey.-Johns Hopkins Univ. Circ., no. 2, 1909, pp. 86-88, 1909.

An administrative report.

237. Some results of an investigation of the coastal plain formations of the area between Massachusetts and North Carolina.-Abstract: Science, new ser., vol. 29, p. 629, April 16, 1909.

Description of the Philadelphia district.-See Bascom and others, no. 74.

Description of the Trenton quadrangle, New Jersey-Pennsylvania.-See Bascom and others, no. 75.

Clark, Wm. Bullock, and Twitchell, M. W.

238. The geological distribution of the Mesozoic and Cenozoic Echinodermata of the United States.-Abstract: Scienco, new ser., vol. 29, p. 635, April 16,1909 . 
Clarke, Frank Wigglesworth.

239. The chemical work of the U. S. Geological Survey.-Science, new ser., vol. 30, pp. 161-171, August 6, 1909.

Clarke, John Mason.

240. Fifth report of the Director of the science division, including the $62 \mathrm{~d}$ report of the State Museum, the 28th report of the State geologist, and the report of the State paleontologist for 1908. Director's report for 1908.-New York State.Mus., Bull. 133, pp. 5-114, 17 pls., 2 figs., 1909.

Outlines the progress of geologic and paleontologic investigation in New York. Includes various data upon the geology and paleontology of the State.

Cleland, Herdman F.

241. Curaçao, a losing colonial venture.-Am. Geog. Soc., Bull., vol. 41, no. 3, pp. 129-138, 6 figs., March, 1909.

Includes a short account of the geology of the island.

242. Some features of the Wisconsin middle Devonic.-Abstract: Science, new ser., vol. 29, p. 637, April 16, 1909.

Cockerell, Theodore Dru Alison.

243. Descriptions and records of bees.-Annals and Mag. Nat. Hist., ser. 8, vol. 1, pp. 337-344, April, 1908.

Includes a description of Protomelecta brevipennis n. sp. from the Miocene shales of Florissant, Colo.

244. The dipterous family Nemestrinidæ.-Am. Entomological Soc., Trans., vol. 34, pp. 247-253, 1 pl., 1908.

Describes insects from the Miocene shales of Florissant, Colo.

245. Another fossil nemestrinid fly.-Am. Entomological Soc., Trans., vol. 34, p. $254,1908$.

Describes Hirmoneura occultator n. sp. from the Miocene shales of Florissant, Colo.

246. A fossil fly of the family Blepharoceridæ.-Entomologist, vol. 41, pp. 262265, 1 fig., November, 1908.

Describes Philorites johannseni n. gen. and n. sp. from the Eocene near Rifle, Colo.

247. Descriptions of Tertiary insects, Part V.-Am. Jour. Sci., 4th ser., vol. 27, pp. 53-58, 1 fig., January, 1909.

Describes new Diptera from the Miocene shales of Florissant, Colo., and the Eocene near Rifle, Colo.

248. Descriptions of Tertiary insects, VI.-Am. Jour. Sci., 4th ser., vol. 27, pp. 381387, 12 figs., May, 1909.

249. Description of Tertiary insects, VII.-Am. Jour. Sci., 4th ser., vol. 28, pp. 283-286, 4 figs., September, 1909.

Describes new genera and species of Orthoptera and Diptera from the Miocene shales of Florissant, Colo.

250. Fossil Diptera from Florissant, Colorado.-Am. Mus. Nat. Hist., Bull., vol. 26, pp. 9-12, 1 pl., 1 fig., 1909.

251. Fossil insects from Flurissant, Colorado.-Am. Mus. Nat. Hist., Bull., vol. 26, pp. 67-76, 1 pl., 1909.

252. Another fossil tsetse fly.-Nature, vol. 80, p. 128, April 1, 1909.

Describes briefly Glossina osborni n. sp. from the Miocene shales of Florissant, Colo.

253. New fossil insects from Florissant, Colorado.-Entomological Soc. America, Annals, vol. 2, pp. 251-256, 1 pl., 1909.

254. Two fossil bees.-Entomological News, vol. 20, pp. 159-161, April, 1909.

Describes Pelandrena n. gen., P. reducta n. sp., and Halictus miocenicus n. sp., from the Miocene shales of Florissant, Colo. 
Cockerell, Theodore Dru Alison-Continued.

255. Fossil insects from Colorado.-Entomologist; vol. 42, pp. 170-174, 3 figs., July, 1909.

Describes insects from Eocene shales near Rifle, Colo., and from the Miocene shales of Florissant, Colo.

256. Two fossil Chrysopidæ.-Canadian Entomologist, vol. 41, no. 7, pp. 218-219, 1 fig., July, 1909.

Describes fossil insects, Palæochrysa concinnula n. sp., and $P$. ferruginea n. sp., from the Miocene shales of Florissant, Colo.

257. New North American bees.-Canadian Entomologist, vol. 41, no. 11, pp. 393-395, November, 1909.

Includes a description of Melitta willardi n. sp., from the Miocene shales of Florissant, Colo.

258. A catalogue of the generic names based on American insects and arachnids from the Tertiary rocks, with indications of the type species.-Am. Mus. Nat. Hist., Bull., vol. 26, pp. 77-86, 1909.

259. Eocene fossils from Green River, Wyoming.-Am. Jour. Sci., 4th ser., vol. 28, pp. 447-448, 2 figs., November, 1.909.

Describes a fruit Firmianites aterrimus new gen. and sp., and an insect Syntomostylus? fortis new sp.

260. A fossil gar-pike from Utah.-Science, new ser., vol. 29, p. 796, May 14, 1909.

261. A fossil ground-sloth in Colorado--Colorado, Univ., Studies, vol. 6, no. 4, pp. 309-312, 2 pls., June, 1909.

262. Fossil Euphorbiaceæ, with a note on Saururaceæ.-Torreya, vol. 9, no. 6, pp. 117-119, 2 figs., June, 1909.

Describes Acalypha myricina n. sp. and Croton furcatulum n. sp. from the Miocene shales of Florissant, Colo., and Tithymalus willistoni $\mathrm{n}$. sp. from the Loup Fork beds of Kansas.

263. Amber in the Laramie Cretaceous.-Torreya, vol. 9, no. 7, pp. 140-142, 1 fig., July, 1909.

Gives notes upon fossil plants from the Cretaceous of Maishall, Boulder County, Colo., and the occurrence of amber. and describes Phragmites laramianus $\mathrm{n}$. $\mathrm{sp}$.

264. Two new fossil plants from Florissant, Colorado.-Torreya, vol. 9, no. 9, pp. 184-185; 2 figs., September, 1909.

Describes Hypolepis coloradensis n. sp. and Bauhinia pseudocotyledon n. sp. from the Miocene shales of Florissant, Colo.

Coffey, George N.

265. Clay dunes.-Jour. Geology, vol. 17, no. 8, pp. 754-755, 1909.

Describes the formation of clay dunes in southern Texas. .

Coleman, Arthur P.

266. Iron ranges of Nipigon district [Ontario].-Ontario, Bur. Mines, 18th Ann. Rept., vol. 18, pt. 1, pp. 141-153, 13 figs., 1909.

Gives notes upon the geology of the district, and the occurrence and character of iron deposits.

267. Black Sturgeon iron region [Ontario].-Ontario, Bur. Mines, 18th Ann. Rept., vol. 18, pt. 1, pp. 163-179, 8 figs., 1 map, 1909.

Gives an account of the geology of the district, and the occurrence and character of iron deposits.

268. Lake Ojibway; last of the great glacial lakes.-Ontario, Bur. Mines, 18th Ann. Rept., vol. 18, pt. 1, pp. 284-293, 1 fig., 1909. Abstract: Science, new ser., vol. 29, p. 628, April 16, 1909.

269. Classification and nomenclature of Ontario drift.-Ontario, Bur. Mines, 18th Ann. Rept., vol. 18, pt. 1, pp. 294-297, 1909. 
Coleman, Arthur P.-Continued.

270. [Clays of Ontario].-Canadian Min. Jour., vol. 30, p. 183, March 15, 1909.

Discusses the nomenclature and source of the clays of Ontario.

271. The bearing of pre-Cambrian geology ' on uniformitarianism.-Abstract: Canadian Min. Jour., vol. 30, pp. 646-647, November 1, 1909.

272. [On the Lower Huronian ice age.]-Canadian Min. Jour., vol. 30, pp. 694-695, November 15, 1909.

Discusses the evidence for the glacial origin of the Lower Huronian conglomerate.

Collier, Arthur J.

273. Classification of low grade coal. Discussion of paper by M. R. Campbell.Econ. Geology, vol. 4, no. 3, pp. 262-264, 1909.

Collier, Arthur J., and Smith, Carl D.

274. The Miles City coal field, Montana.-U. S. Geol. Survey, Bull. 341, pp. 36-61, $1 \mathrm{pl} ., 1909$.

Describes the stratigraphy and structure of the field, the occurrence, character, and relations of the coal beds, the character of the coal, and the mining developments.

Collins, W. F.

275. Occurrence of gold in placers.-Min. and Sci. Press, vol. 98, p. 850, June 19, 1909.

Collins, W. H.

276. Preliminary report on Gowganda mining division, district of Nipissing, Ontario.-Canada, Geol. Survey Branch, Publ. no. 1075, 1909. 47 pp., 7 figs., 1 map. Abstract: Canadian Min. Jour., vol. 30, pp. 369-371, 392-394, 3 figs., 1909.

Describes the general features of the region, the occurrence and relations of pre-Cambrian formations and glacial deposits, and the mineral deposits, particularly silver.

277. A geological reconnaissance of the region traversed by the National Transcontinental Railway between Lake Nipigon and Clay Lake, Ontario.Canada, Geol. Survey Branch, 67 pp., 2 pls., 1 fig., 2 maps, 1909.

278. Report on the region lying north of Lake Superior between the Pic and Nipigon rivers, Ontario.-Canada, Geol. Survey, 24 pp., 1. map, 1909.

279. Montreal River district.-Canada Geol. Survey, Summ. Rept., 1908, pp. 115120, 1909. Abstract: Min. and Sci. Press, vol. 98, p. 895, 1909.

Describes the general geology, the areal distribution of formations, and the occurrence of silver, iron ore, and asbestos.

Condit, D. Dale.

280. The Conemaugh formation in southern Ohio.-Ohio Naturalist, vol. 9, no. 6, pp. 482-488, April, 1909.

Describes the stratigraphy of the formation and gives lists of fossils from the Ames and Cambridge limestones and notes on their occurrence.

Conrad, Timothy A.

Fossil shells from Tertiary deposits on the Columbia River, near Astoria (reprinted from Am. Jour. Sci., 2d ser., vol. 5, pp. 432-433, 1848).U. S. Geol. Survey, Prof. Paper 59, pp. 150-151, 14 figs., 1909.

Notes on shells, with descriptions of new species (reprinted from Acad. Nat. Sci. Philadelphia, Proc., vol. 6, pp. 199-200, 1853).-U. S. Geol. Survey, Prof. Paper 59, p. 158, 1909.

Descriptions of new fossil shells of the United States (reprinted from Acad. Nat. Sci: Philadelphia, Jour., vol. 2, pt. 3, pp. 273-276, 1853).-U. S. Geol. Survey, Prof. Paper 59, pp. 159-161, 1909. 
Conrad, Timothy A.-Continued.

Notes on shells, with descriptions of three recent and one fossil species (reprinted from Acad. Nat. Sci. Philadelphia, Proc., vol. 7, pp. 31-32, 1854).-U. S. Geol. Survey, Prof. Paper 59, p. 162, 1909.

Descriptions of fossil shells from the Eocene and Miocene formations of California (reprinted from Description of the fossils and shells collected in California by William P. Blake [H. Doc. 129], Washington, 1855. Appendix to the preliminary geological report of William P. Blake, Paleontology, pp. 9-20).-U.'S. Geol. Survey, Prof. Paper 59, pp. 163-171, 1909.

Note on the Miocene and post-Pliocene deposits of California, with descriptions of two new fossil corals (reprinted from Acad. Nat. Sci. Philadelphia, Proc., vol. 7, p. 441, 1855).-U. S. Geol. Survey, Prof. Paper 59, p. 172, 1909.

Descriptions of three new genera, twenty-three new species middle Tertiary fossils from California, and one from Texas (reprinted from Acad Nat. Sci. Philadelphia, Proc., vol. 8, pp. 312-316, 1856).-U. S. Geol Survey, Prof. Paper 59, pp. 173-175, 1909.

Description of the Tertiary fossils collected on the survey (reprinted from Pacific R. R. repts., vol. 6, pt. 2, no. 2, pp. 69-73, 1857).-U. S. Geol. Survey, Prof. Paper 59,.pp. 176-179, 1909.

Report on the paleontology of the survey (reprinted from Pacific R. R. repts., vol. 7, pp. 189-196, 1857).-U. S. Geol. Survey, Prof. Paper 59, pp. 180$185,1909$.

Cook, C. W.

Iodyrite from Tonopah, Nevada, and Broken Hill, New South Wales.-See Kraus and Cook, no. 681.

Cook, Harold James.

281. Notice of a new camel from the lower Miocene of Nebraska.-Am. Naturalist, vol. 43, pp. 188-189, March, 1909.

Describes briefly a specimen from the lower Harrison beds, near Agate, Sioux County, Nebr., for which the name Oxydactylus campestris n. sp. is proposed.

282. A new proboscidean from the lower Miocene of Nebraska.-Am. Jour. Sci., 4th ser., vol. 28, pp. 183-184, 1 fig., August, 1909.

Describes Gomphotherium conodon n. sp.

A Pliocene fauna from western Nebraska.-See Matthew and Cook, no. 840.

Cook, John H.

283. Some preglacial valleys in eastern New York and their relation to existing drainage.-Abstract: Science, new ser., vol. 29, p. 750, May 7, 1909.

Cooledge, C. W., and Overspeck, L. S.

284. The iron deposits of the Black Hills, South Dakota.-Min. Science, vol. 60, pp. 31.9-321, October 7, 1909.

Cooper, W. F.

285. Paleozoic geology of Tuscola County, Michigan. With notes on the Marshall. and Grand Rapids formations by Alfred C. Lane and Chas. A. Davis.Michigan Miner, vol. 11, no. 6, pp. 9-20, 1 fig., May, 1909.

Describes the character, occurrence, and relations of Carboniferous formations, and the geologic relations and character of the coal seams.

Corss; Frederic.

286. A study of the glacial rock on Shawnee Mountain. [Pennsylvania].-Wyoming Hist. and Geol. Soc., Proc. and Coll., vol. 10, pp. 11.5-117, 1 pl., 1909.

Describes a rock showing glacial striæ. 
Coste, Eugene.

287. Petroleums and coals compared in their nature, mode of occurrence, and origin.-Canadian Min. Jour., vol. 30, pp. 295-300, May·15, 1909; pp. 330-334, June 1, 1909.

288. The volcanic or organic origin of oil.-Min. Science, vol. 60, pp. 367-368, October 21, 1909.

Cox, G. H.

289. Copper in southwestern Wisconsin.-Min. and Sci. Press, vol. 99, p. 592, 1 fig., October 30, 1909.

Crawford, R. D.

290. Geology and petrography of the Sugarloaf district, Boulder County, Colorado.-Colorado, Univ., Studies, vol. 6, no. 2, pp. 97-131, 3 pls., February, 1909.

291. Notes on the intrusive rocks of Boulder County, Colorado.-Colorado Geol. Survey, Ist Rept., 1908, pp. 23-36, 1909.

The Hahns Peak region, Routt County, Colorado.-See George and Crawford, no. 446.

Croasdale, Stuart:

292. Chart of igneous rocks.-Min. and Sci. Press, vol. 99, pp. 598-599, October $30,1909$.

Arranges in tabular form the characteristics of igneous rocks to aid in their determination.

Crosby, William O.

293. A study of the geology of the Charles River estuary and the formation of Boston Harbor.-Massachusetts, Report of the Committee on Charles River dam, Boston, 1903; Appendix no. 7, pp. 345-369, 2 pls., 1903.

Cross, Whitman.

294. The Laramie formation and the Shoshone group.-Washington Acad. Sci., Proc., vol. 11, no. 1, pp. 27-45, 1909.

Discusses the application of the term Laramie group and proposes the term Shoshone group for the deposits resting unconformably upon the Laramie as restricted.

295. Fluidal gneiss and contemporary pegmatites.-Abstract: Science, new ser., vol. 29, p. 946, June 11, 1909.

296. The Slumgullion mud flow.-Abstract: Science, new ser., vol. 30, pp. 126-127, July 23, 1909.

Curtis, Roy P.

Dredging at Breckenridge, Colorado.-See Bradford and Curtis, no. 133.

Dale, T. Nelson.

297. The granites of Vermont.-U. S. Geol. Survey, Bull. 404, 138 pp., 5 pls., 25 figs., 1909.

Dall, William Healey.

298. Biographical memoir of William More Gabb, 1839-1878. (Read before the National Academy of Sciences, November 18, 1908.) City of Washington, March, 1909.-Nat. Acad. Sci., Biog. Mem., vol. 6, pp. 345-361, 1 pl. (port.), 1909.

Includes a list of his writings.

299. Conditions governing the evolution and distribution of Tertiary faunas.Jour. Geology, vol. 17, no. 6, pp. 493-502, 1909.

56693-Boll. 444-10-3 
Dall, William Healey-Continued.

300. Contributions to the Tertiary paleontology of the Pacific coast. I. The Miocene of Astoria and Coos Bay, Oregon.-U. S. Geol. Survey, Prof. Paper 59, 278 pp., 23 pls., 14 figs., 1909.

Discusses the stratigraphic position of the beds and gives systematic descriptions of the invertebrates. Appendixes contain reprints of rare papers by Conrad, Daua, Shumard, and Carpenter pertaining to the investigation.

301. Material toward a bibliography of publications on the post-Eocene marine molluscs of the northwest coast of America, 1865-1908.-U. S. Geol. Survey, Prof.Paper 59, pp. 192-216, 1909.

Dalton, Leonard V.

302. On the origin of petroleum.-Econ. Geology, vol, 4, no. 7, pp. 603-631, 1909.

Daly, Reginald A.

303. First calcareous fossils and the evolution of the limestones.-Geol. Soc. America, Bull., vol. 20, pp. 153-170, April, 1909.

Discusses the calcium and magnesium content of the ocean in pre-Cambrian and later time and presents data from analyses of river waters for determining this.

Dana, Edward S., and Ford, William E.

304. Second appendix to the sixth edition of Dana's System of Mineralogy. New York, John Wiley \& Sons, 1909. 114 pp., illus.

Dana, James D.

Fossils from northwestern America (reprinted from U. S. Explor. Exped., Geology, Appendix 1, pp. 722-730, 1849).-U. S. Geol. Survey, Prof. Paper 59, pp. 152-157, 1909.

Daneš, Jiři V.

305. Absence de traces glaciaires dans la Californie méridionale-La Géographie, · Paris, t. 19, no. 2, pp. 120-122, 1909.

Notes the absence of evidences of glacial action in the Coast Ranges and Sierra Nevada of southern California.

Darton, Nelson Horatio.

306. Geology and water resources of the northern portion of the Black Hills and adjoining regions in South Dakota and Wyoming.-U. S. Geol. Survey, Prof. Paper 65, 105 pp., 24 pls., 15 figs., 1909.

307. Geology and underground waters of South Dakota.-U. S. Geol. Survey, Water-Supply Paper 227, 156 pp., 15 pls., 7 figs., 1909.

308. Structural materials in parts of Oregon and Washington.-U. S. Geol. Survey, Bull. 387, 33 pp., 9 pls., 1 fig., 1909.

Gives an account of the general geology and the occurrence and quality of various structural materials.

309. Geologic basis for artesian prediction.-American Water Works Assoc., Proc. 28th Ann. Conv., 1908, pp. 280-291, 7 figs., 1909.

310. Discovery of fish remains in Ordovician of the Black Hills, South Dakota.Abstract: Geol. Soc. America, Bull., vol. 19, pp. 567-568, 1909.

Discusses briefly the stratigraphic position of the Whitewood limestone in which the fossils were found.

311. The stream robbery on which the Belle Fourche reclamation project is based.Abstract: Science, new ser., vol. 29, pp. 556-557, April 2, 1909.

Description of the Philadelphia district.-See Bascom and others, no. 74 .

Description of the Trenton quadrangle, New Jersey-Pennsylvania.-See Bascom and others, no. 75. 
Dartion, N. H., and O'Harra, C. C.

312. Description of the Belle Fourche quadrangle, South Dakota.-U. S. Geoi. Survey, Geol. Atlas U. S., Belle Fourche folio (no. 164), library edition, 9 pp., 4 maps, field edition, 67 pp., 5 maps (folded, in pocket), 1909.

Describes the geography, the stratigraphy, including Carboniferous, Triassic, Jurassic, Cretaceous, and Quaternary formations, the geologic structure, the geologic history, the mineral resources, and the underground water conditions.

Darton, N. H., and Siebenthal, C. E.

313. Geology and mineral resources of the Laramie Basin, Wyoming.-U. S. Geol. Survey, Bull. 364, 81 pp., 8 pls., 1 fig., 1909.

Describes the geography and general geology, the occurrence, character, and relations of Carboniferous, Triassic, Jurassic, Cretaceous, and Tertiary formations, the geologic structure, the mineral resources, including coal, gypsum, bentonite, and others, and the underground waters.

Davis, Charles A.

314. Preliminary report of peat deposits in North Carolina.-North Carolina Geol. and Econ. Survey, Econ. Paper no. 15, pp. 147-162, 1908.

315. The possible use of peat fuel in Alaska.-U. S. Geol. Survey, Bull. 379, pp. 63-66, 1909.

316. Peat resources of the United States, exclusive of Alaska.-U. S. Geol. Survey, Bull. 394, pp. 62-69, 1909. Rept. Nat. Conservation Comm. (60th Cong., 2d sess., Sen. Doc. no. 676), vol. 3, pp. 476-482, 1909.

317. On the origin of peat.-Abstract: Science, new ser., vol. 29, p. 947, June 11, 1909.

Peat deposits of Maine.-See Bastin and Davis, no. 83.

Notes on the Marshall sandstone.-See Cooper, no. 285.

Mineral resources of the United States, 1908: Peat.-See no. 1170.

Davis, William Morris.

318. Geographical essays. Boston, Ginn and Company, 1909. vi, 777 pp., 130 figs.

Includes essays on physiographic'subjects reprinted from various journals.

319. Der grosse Cañon des Colorado-Flusses.-Gesellsch. Erdkunde zu Berlin, Zeitsch., no. 3, pp. 164-172, 7 figs., 1909.

Describes the physiographic features and history of the great canyon of the Colorado River in northern Arizona.

320. The Colorado Canyon; some of its lessons.-Geog. Jour., London, vol. 33, no. 5, pp. 535-540, May, 1909.

321. The lessons of the Colorado Canyon.-Am. Geog. Soc., Bull., vol. 41, no. 6, pp. 345-354, 2 figs., June, 1909.

Describes the history of the canyon.

322. The systematic description of land forms.-Geog. Jour., vol. 34, no. 3, pp. 300318, 17 figs., September, 1909.

323. The physiographic subdivisions of the Appalachian Mountain system, and their effects upon settlement and history.-Abstract: British Assoc. Adv. Sci., Rept. 78th Meeting, pp. 761-762, 1909.

324. The Colorado Canyon.-Abstract: British Assoc. Adv. Science, Rept. 78th Meeting, pp. 948-949, 1909.

Day, Arthur L.

325. Diopsid€ and its related minerals.-Abstract: Scieuce, new ser., vol. 30, pp. 125-126, July 23, 1909. 
Day, David T.

326. The petroleum resources of the United States.-U. S. Geol. Survey, Bull. 394, pp. 30-50, 4 pls., 1909. Rept. Nat. Conservation Comm. (60th Cong., 2d sess., Sen. Doc. no. 676), vol. 3, pp. 446-464, 4 pls., 1909.

327. Natural-gas resources of the United States.-U. S. Geol. Survey, Bull. 394, pp. 51-61, 1909. Rept. Nat. Conservation Comm. (60th Cong., 2d sess., Sen. Doc. no. 676), vol. 3, pp. 465-475, 1909.

328. [Map of United States showing] known productive oil and gas fields of the United States in 1908. Second edition.-U. S. Geological Survey, 1909. Scale 110 miles to one inch.

329. The Mexican oil fields, their geology and the character of the oils.-Petroleum Review, vol. 20, p. 323, 4 figs., June 5, 1909.

330. Analyses of crude petroleum from Oklahoma and Kansas.-U.S. Geol. Survey, Bull. 381-D (advance chapter), pp. 22-31, 1909.

Mineral resources of the United States, 1908: Platinum; petroleum.-See no. 1170.

Dean, Bashford.

331. Studies on fossil fishes (sharks, chimæroids, and arthrodires).-Am. Mus. Nat. Hist., Mem., vol. 9, pt. 5, pp. 209-287, 16 pls., 63 figs., February, 1909.

332. The giant of ancient sharks.-Am. Mus. Jour., vol. 9, no. 8, pp. 233-234, 1 pl., December, 1909.

Gives notes upon a restoration of the jaws of Carcharodon megalodon on exhibition in the American Museum of Natural History.

De Kalb, Courtenay.

333. Copper mining at Ely, Nevada.-Min. and Sci. Press, vol. 98, pp. 58-60, 1 fig., January 2, 1909.

Includes notes on the geology and the occurrence of the copper ores.

334. The Utah copper mine.-Min. and Sci. Press, vol. 98, pp. 516-521, 7 figs., April 10, 1909.

Includes notes on the occurrence of the copper ores in Bingham Canyon, Utah.

335. Boston Consolidated, Bingham, Utäh.-Min. and Sci. Press, yol. 98, pp. 553556, 6 figs., April 17, 1909.

Includes notes on the occurrence of copper ores in Bingham Canyon, Utah.

336. Geologic essentials of a mine report.-Min. and Sci. Press, vol. 98, pp. 625628, May 1, 1909.

DeWolf, Frank W.

337. The coal resources of Illinois.-Illinois State Geol. Survey, Bull. no. 14, pp. 189-196, 1909.

Dickinson, H. P.

338. Occurrence, character, and uses of some rare metals.-Min. Science, vol. 57, pp. 123-124, January 30, 1908.

Diller, Joseph Silas.

339. The Rogue River valley coal field, Oregon.-U. S. Geol. Survey, Bull. 341, pp. 401-405, 1 fig., 1909.

Mineral resources of the United States, 1908: Asbestos; talc and soapstone.-See no. 1170.

Diller, Joseph Silas, and Kay, G. F.

340. Mineral resources of the Grants Pass quadrangle and bordering districts, Oregon.-U. S. Geol. Survey, Bull. 380, pp. 48-79, 1 pl. (map), 1909.

Describes the general geology, the occurrence, character, and relations of Paleozoic, Jurassic, Cretaceous, Tertiary, and igneous rocks, the geologic structure, the mineral resources, chiefly quartz- and placer-gold and copper, and the mining developments. 
Dinsmore, Chas. A.

341. The Patagonia district, Arizona.-Min. World, vol. 31, p. 224, July 24, 1909.

342. The Johnson and Dragoon districts, Arizona.-Min. World, vol. 31, pp. 833834, 4 figs., October 23, 1909.

Includes notes on the local geology and the occurrence and character of the copper ores.

343. Quicksilver deposits of Brewster County, Texas.-Min. World, vol. 31, pp. 877-878, 6 figs., October 30, 1909.

344. Development of a Texas tin mine.-Min. World, vol. 31, p. 1120, December 4, 1909.

Includesnotes on the geology of the region and the occurrence of tin ore on Mount Franklin, near El Paso, Tex.

Dole, Richard B., and Stabler, $\dot{\mathrm{H}}$.

345. Denudation.-U. S. Geol. Survey, W.-S. Paper 234, pp. 78-93, 1909. Rept. Nat. Conservation Comm. (60th Cong., 2d sess., Sen. Doc. no. 676), vol. 2, pp. 126-140, 1 pl., 1909.

346. Denudation in the United States.-Abstract: Science, new ser., vol. 29, p. 313 , February 19, 1909.

Presents estimates as to the rate of denudation.

Douglass, Earl.

347. Description of a new species of Procamelus from the upper Miocene of Montana, with notes upon Procamelus madisonius Doùglass.-Carnegie Mus., Annals, vol. 5, pp. 159-165, 3 pls., 2 figs., 1909.

348. A geological reconnaissance in North Dakota, Montana, and Idaho; with notes on Mesozoic and Cenozoic geology:-Carnegie Mus., Annals, vol. 5, pp. 211-288, 7 pls., 1909.

349. Dromomeryx, a new genus of American ruminants.-Carnegie Mus., Annals, vol. 5, pp. 457-479, 5 pls., 3 figs., 1909.

Dowling, D. B.

350. The coal fields of Manitoba, Saskatchewan, Alberta, and eastern British Columbia.-Canada, Geol. Survey, 111 pp., 11 pls., 2 figs., 1 map, 1909.

351. Steam coals of the Cascade basin; lignite areas of Alberta and Saskatchewan; production of coal in Alberta and Saskatchewan.-Canada Geol. Survey, Summ. Rept., 1908, pp. 77-86, 1909.

352. The coal fields of Alberta.-Econ. Geology, vol. 4, no. 1, pp. 1-11, 1 fig., 1909.

353. Report on Bighorn, Brazeau, and Saskatchewan coal lands [Alberta].Canadian Min. Jour., vol. 30, pp. 77-78, February 15, 1909.

354. Pressure in the formation and alteration of coal.-Canadian Min. Jour., vol. 30, pp. 102-104, February 15, 1909.

355. Abstract of report on the Kananaskis coal area [Alberta].-Canadian Min. Jour., vol. 30, p. 141, March 1, 1909.

356. Chemical changes in the formation of coal.-Min. World, vol. 31, pp. 507-510, 7 figs., September 4, 1909.

Dresser, John A.

357. A geological reconnaissance along the National Transcontinental Railway from the St. Lawrence River to the interprovincial boundary between 'Quebec and New Brunswick.-Canada, Geol. Survey, Summ. Rept., 1908, pp. 124-128, 1909.

358. On a rare rock type from the Monteregian Hills, Canada.-Am. Jour. Sci., 4th ser., vol. 28, pp. 71-73, July, 1909.

359. On the asbestos deposits of the eastern townships of Quebec.-Econ. Geology, vol. 4, no. 2, pp. 130-140, 4 figs., 1909. 
Dresser, John A.-Continued.

360. The asbestos industry of eastern Quebec.-Min. World, vol. 30, pp. 593-595, 4 figs., March 27, 1909.

Describes the geology of the district, the character, relations, and origin of the veins, and the character and occurrence of the asbestos.

361. Mineral deposits of the serpentine belt of southern Quebec.-Canadian Min. Jour., vol. 30, pp. 334-339, 365-368, 6 figs., 1909.

Describes the general geology and the occurrence of asbestos, chromite, talc, copper, antimony, and nickel deposits.

Dulieux, E.

362. Report on an exploration in the region of Lakes Chibougamau, Doré, David, and Asinichibastat [Quebec].-Quebec, Dept. of Colonization, Mines, and Fisheries, Mining Operations, 1908, pp. 50-83, 10 pls., 1909.

Includes an account of the geology and the mineral resources of the region.

Dumble, E. T.

363. The Texas Tertiaries-a correction.-Science, new ser., vol. 29, pp. 113-114, January 15, 1909.

Discusses the stratigraphic position of certain beds.

Duncanson, H. B.

364. Observations on the shifting of the channel of the Missouri River since 1883.Science, new ser., vol. 29, pp. 869-871, 1 fig., May 28, 1909.

Eastman, Charles R.

365. A new species of Helodus.-Carnegie Mus., Annals, vol. 5, pp. 488-489, 1909.

Describes Helodus comptus n. sp. from the Meadville upper limestone (base of the Waverly) at Meadville, $\mathrm{Pa}$.

366. Mylostomid dental plates.-Science, new ser., vol. 29, pp. 997-998, June 25, 1909.

367. Mylostomid palatal dental plates.-Harvard Coll., Mus. Comp. Zool., Bull., vol. 52, no. 14, pp. 261-269, 3 figs., December, 1909.

Discusses the position of the palatal dental plates in the Mylostomatidæ.

Eaton, H. N.

368. Notes on the petrography of the granites of Chapel Hill, North Carolina.Elisha Mitchell Sci. Soc., Jour., vol. 25, no. 3, pp. 85-91, November, 1909.

Eberle, Frank.

369. The Arkansas diamond fields.-Min. World, vol. 31, pp. 285-286, 4 figs., July 31, 1909.

Eckel, Edwin C.

Mineral resources of the United States, 1908: Cement industry in the United States in 1908.--See no. 1170.

\section{Ekeley, John B.}

370. The composition of some Colorado tungsten ores.-Colorado, Univ., Studies, vol. 6, no. 2, pp. 93-96, February, 1909. Min. World, vol. 30, p. 280, February 6, 1909.

Ellis, E. E.

371. Ground water in the crystalline rocks of Connecticut.-U. S. Geol. Survey, Water-Supply Paper 232, pp. 54-103, 3 pls., 4 figs., 1909.

Ells, R. W.

372. Notes on mineral fuels of Canada.-Nova Scotia Inst. Sci., Proc. and Trans., vol. 12 , pt. 1, pp. 61-71, 1908. 
Ells, R. W.-Continued.

373. Notes on a proposed new base for the Cambrian rocks of southern New Brunswick.-Roy. Soc. Canada, Proc. and Trans., 3d ser., vol. 2, sect. 4, pp. 113-120, 1908.

Discusses the age and correlation of various beds in the vicinity of St. John, New Brunswick.

374. Bituminous shales of Nova Scotia and New Brunswick, with notes on the geology of the oil-shales of Scotland.-Canada, Geol. Survey, Summ. Rept., 1908, pp. 132-142, 1909.

Emmons, Newton W.

375. Mineral resources of the Lardeau district, British Columbia.-Min. World, vol. 31, pp. 555-559, 1 fig., September 11, 1909.

Includes notes on the occurrence of ores.

Emmons, Samuel Franklin.

376. Economic geology in the United States.-Min. World, vol. 30, pp. 1209-1211, June 26, 1909.

Reviews the progress in the geological investigation of the mineral resources of the United States.

377. Development of modern theories of ore deposition.-Min. and Sci. Press, vol. 99, pp. 400-403, September 18, 1909.

Emmons, William H.

378. Some regionally metamorphosed ore deposits and the so-called segregated veins.-Econ. Geology, vol. 4, no. 8, pp. 755-781, 2 pls., 1909.

Discusses the occurrence and genesis of copper deposits of the "segregated vein" type in eastern North America from Quebec to Georgia and Tennessee, and more particularly in Maine and New Hampshire.

379. Outcrop of ore bodies.-Min. and Sci. Press, vol. 99, pp. 751-754, 782-787, 11 figs., December 4 and 11, 1909.

Estes, A. W.

380. Mineral resources of Arkansas:-Am. Min. Congress, 11th Ann. Sess., Papers and Proc., pp. 146-151, 1909.

Evans, A. W.

381. Lahausage mine, Alabama.-Mines and Minerals, vol. 30, pp. 77-79, 2 figs.; September, 1909.

Includes a short account of the geology of the field and the occurrence and character of the coal.

Evans, Horace F.

382. The correlation of the international strata.-Min. World, vol. 30 , pp. 21-22, $55-56,129,1909$.

Eyerly, T. L.

383. The geology of Hemphill County [Texas]. With a brizf description of its topography, water supply, and soils. [1907.] 16 pp., 2 pls. [Private publication?]

Fairbanks, Harold W.

384. Physiography, an elementary.science course in the High School.-Jour. Geog., vol. 7, no. 10, pp. 217-226, June, 1909.

Fairchild, Herman Le Roy.

385. Glacial waters in central New York.-New York .State Mus., Bull. 127, 66 pp., 42 pls.; 1909.

386. Multiple glaciation in New York.-Abstract:. Science, new ser., vol. 29, p. 626, April 16, 1909. 
Fairchild, Herman Le Roy-Continued.

387. Correlation of the Hudsonian and the Ontarian glacier lobes.-Abstract: Science, new ser., vol. 29, p. 627, April 16, 1909.

388. Glacial waters west and south of the Adirondacks.-Abstract: Science, new ser., vol. 29, p. 627, April 16, 1909.

389. Drainage evolution in central New York.-Abstract: Science, new ser., vol. 29, pp. 632-633, April 16, 1909.

Faribault, E. Rodolphe.

390. Southern part of Kings and eastern part of Lunenburg counties, Nova Scotia.Canada, Geol. Survey, Summ. Rept., 1908, pp. 150-1.58, 1909.

Describes the geologic structure of the area, and the occurrence and relations of goldbearing rocks and tungsten deposits.

Fay, Albert H.

391. The Vermont Copper Company.-Eng. and Min. Jour., vol. 88, pp. 364-365, 3 figs., August 21, 1909.

Includes notes on the occurrence of copper ores in Orange County, Vt.

Fenneman, N. M.

392. Physiography of the St. Louis area.-Illinois State Geol. Survey, Bull. no. 12, 83 pp., 18 pls., 10 figs., 1909.

393. Problems in the teaching of physical geography in secondary schools.--Jour. Geog., vol. 7, no. 7, pp. 145-157, March, 1909.

Ferguson, Edw. G. W.

394. The mineral resources of Haiti, West Indies.-Min. World, vol. 31, pp. 133135, July 10, 1909.

Finch, J. W.

395. A vein and its apex.-Min. and Sci. Press, vol. 99, p. 525, October 16, 1909.

Discusses the definition of the terms vein, apex, vein matter, and ore.

Fisher, Cassius A.

396. Geology of the Great Falls coal field, Montana.-U. S. Geol. Survey, Bull. 356, 85 pp., 12 pls., 2 figs., 1909.

Describes the topography, the occurrence, relations, and character of Carboniferous, Jurassic, Cretaceous, and Tertiary formations, the occurrence and character of coal beds, and the character of the coal.

397. Geology and water resources of the Great Falls region, Montana.-U. S. Geol. Survey, Water-Supply Paper 221, 89 pp., 7 pls., 1909.

398. The Pocket coal district, Virginia, in the Little Black Mountain coal field.U. S. Geol. Survey, Bull. 341, pp. 409-418, 1 fig., 1909.

Describes the topography and structure of the field, the geologic occurrence of the coal, the distribution, relations, and character of the coal beds, and the quality and composition of the coals.

Fleck, Herman.

399. Welfare of Colorado's rare metal industry.-Colorado School of Mines, Bull., vol. 4, no. 4, pp. 234-242, January, 1909.

Includes notes on the occurrence of uranium and vanadium.

400. The uranium and vanadium deposits of Colorado.-Min. World, vol. 30, pp. 596-598, 2 figs., March 27, 1909.

401. Colorado's rare metal industry.-Mines and Minerals, vol. 30 , pp. 63-64, August, 1909.

402. How to recognize pitchblende.-Eng. and Min. Jour., vol. 88, p. 1026, November 20,1909 . 
Fleming, W. L.

403. Notes on the Rainy River district, Ontario.-Eng. and Min. Jour., vol. 88, pp. 1064-1066, 2 figs., November 27, 1909.

Includes notes on the occurrence of the gold ores.

Fletcher, Hugh.

404. Section of rocks from Schulie to Spicer Cove, Cumberland Co., N. S., in descending order.-Nova Scotian Inst. Sci., Proc. and Trans., vol. 11, pt. 3, pp. 500-548, 3 pls. (maps and sections), 1908.

405. Report on a portion of Cumberland County, Nova Scotia.-Canada Geol.

Survey, Summ. Rept., 1908, pp. 143-149, 1909.

Gives various notes on the geology of the area examined.

Flores, Teodoro.

406. El hundimiento del cerro de Sartenejas en los alrededores de Tetecala, Estado de Morelos.-Mexico, Inst. Geol., Parerg., t. 2, no. 9, pp. 363384, 2 pls., 1 map, 1909.

Describes the physiographic features and general geology of the vicinity of Tetecala, State of Morelos, and explains a sinking of the earth which took place suddenly at the locality.

407. Datos para la geologia del Estado de Oaxaca.-Soc. Geol. Mexicana, Bol., t. 5, pp. 107-128, 2 pls., 1909.

Gives data regarding the physiographic features and geology of the State of Oaxaca, Mexico.

408. Los yacimientos de tecali de los alrededores de Tequisistlan, municipalidad del mismo nombre, distrito de Tehuantepec, Estado de Oaxaca.-Soc. Geol. Mexicana, Bol., t. 6, pp. vii-viii, 67-78, 3 pls., 1909.

Gives a brief account of deposits of Mexican onyx near Tequisistlan in the State of Oaxaca, Mexico.

Geologic study of the Sierra of Guanajuato.-See Villarello, Flores, and Robles, no. 1192.

\section{Foerste, August $F$.}

409. Silurian fossils from the Kokomo, West Union, and Alger horizons of Indiana, Ohio, and Kentucky.-Cincinnati Soc. Nat. Hist., Jour., vol. 21, no. 1, pp. 1-41, 2 pls., 1909.

410. The Bedford fauna at Indian Fields and Irvine, Kentucky.-Ohio Naturalist, vol. 9, no. 7, pp. 515-523, 1 pl., May, 1909.

Gives notes upon the stratigraphy of lower Mississippian formations in Kentucky and Ohio, and the faunas, and descriptions of fossils from the Bedford-Berea rocks of Kentucky.

411. Fossils from the Silurian formations of Tennessee, Indiana, and Kentucky.Denison Univ., Sci. Lab., Bull., vol. 14, pp. 61-116, 4 pls., 1909.

412. Preliminary notes on Cincinnatian fossils.-Denison Univ., Sci. Lab., Bull., vol. 14, pp. 208-232, 1 pl., June, 1909.

413. Preliminary notes on Cincinnatian and Lexington fossils.-Denison Univ., Sci. Lab., Bull., vol. 14, pp. 289-334, 5 pls., November, 1909.

The systematic descriptions of fossils are preceded by a discussion upon the correlation and distribution of upper Ordvician formations and horizons.

414. The Brachiopoda of the Richmond group.-Abstract: Science, new ser., vol. 29, p. 635, April 16, 1909.

The Waverly formations of east central Kentucky.-See Morse and Foerste, no. 887 . 
Fohs, F. Julius.

415. Kentucky fluorspar and its value to the iron and steel industries.-Am. Inst. Min. Eng., Bull., no. 28, pp. 411-423, April, 1909. Abstract: Min. World, vol. 30, pp. 1217-1220, June 26, 1909.

Ford, William E.

416. Neptunite crystals from San Benito County, California.-Am. Jour. Sci., 4th ser., vol. 27, pp. 235-240, 11 figs., March, 1909. Zeitschr. Krystal. und Mineral., Bd. 46, Heft 4, pp. 321-325, 11 figs., 1909.

Describes the occurrence and crystallographic characters.

Second appendix to the sixth edition of Dana's System of Mineralogy.-See Dana and Ford, no. 304.

Ford, W. E., and Pogue, J. L.

417. Calcite crystals from Kelly's Island, Lake Erie.-Am. Jour. Sci., 4th ser., vol. 28, pp. 186-187, August, 1909.

418. Crystals of datolite from Bergen Hill, New Jersey.-Am. Jour. Sci., 4th ser., vol. 28, p. 187, August, 1909.

Ford, W. E., and Tillotson, E. W:

Orthoklaszwillinge von ungewöhnlicher Ausbildung [Orthoclase twins of unusual habit].-Zeitschr. Krystall. und Mineral., Bd. 46, Heft 2, pp. 129-134, 6 figs., 1909. See no. 362 (Bibliography for 1908) of Bulletin 409, U. S. Geol. Survey.

Ford, W. E., and Ward, Freeman.

419. Calamine crystals from the Organ Mountains, Donna Anna County, New Mexico.-Am. Jour. Sci., 4th ser., vol. 28, pp. 185-186, 4 figs., August, 1909.

Forstner, William.

420. Oil measures in the Coalinga district [California].--Min. and Sci. Press, vol. 98, pp. 386-387, March 13, 1909.

421. Historical geology of California.-Min. and Sci. Press, vol. 98, pp. 853-858, 891-892; vol. 99, pp. 55-58, 91-92, 7 figs., 1909.

422. Geology of the Coalinga oil district.-Min. and Sci. Press, vol. 99, pp. 566-567, 1 fig., October 23, 1909.

Fraas, Eberhard.

423. Weitere Beiträge zur Fauna des Jura von Nordost-Groenland.-Meddelelser om Grønland, H. 29, pp. 277-285; 4 figs., 1904.

Describes a footprint supposed to have been made by a small dinosaur and a vertebra of ophthalmosaurus (Baptanodon) from the Jurassic of Jameson Land, Greenland.

424. In den Bad Lands von Süd-Dakota.-Aus der Natur, Jg. 2, Heft 17, pp. 513-521, Heft 18, pp. 552-559, 10 figs., 1906.

A general account of the Bad Lands of South Dakota and the noteworthy fossils found in them.

425. Vergleichung der amerikanischen und europäischen Juraformation.-Intern. Amerikanisten-Kongress, Tag. 14, Stuttgart, 1904, pp. 41-45, 1906.

Compares the Jurassic deposits of Württemberg, Germany, with those of the Great Plains.

Frecheville, William, and Marriott, Hugh F:

426. $A$ visit to the mineral districts of Canada.-Inst. Min. and Metal., London, Trans., vol. 18, pp. 158-179, 1 pl. (map), 1909. 
Free, E. E.

427. A possible error in the estimates of the rate of geologic denudation.- Science, new ser., vol. 29, pp. 423-424, March 12, 1909.

Calls attention to eolian action in transporting material to the sea.

428. The phenomena of eolian sand drift.-Abstract: Science, new ser., vol. 29, p. 751 , May 7, 1909 .

Freeman, John R.

429. Report on subsidence of land and harbor bottom.-Massachusetts, Report of the committee on Charles River dam; Boston, 1903; Appendix no. 20, pp. 529-572.

Presents various data to show that Boston, Mass., is slowly sinking into the sea and the harbor bottom tends to slowly become deeper.

Freudenberg, Wilhelm.

430. Geologische Beobachtungen im Gebiete der Sierra Nevada von Mexiko.Deutsch. geol. Gesell., Monatsber., no. 5, pp. 254-274, 6 figs., 1909.

Gives observations upon the physiography and geology of the Sierra Nevada Mountains, of Mexico.

Fuller, John T.

431. Diamond mine in Pike County, Arkansas.-Eng. and Min. Jour., vol. 87, pp. 152-155, 5 figs.; January 16, 1909.

Fuller, Myron L.

432. Artesian waters of the Atlantic Coastal Plain.-American Water Works Assoc., Proc. 28th Ann. Conv., 1908, pp. 294-322, 10 figs., 1909.

Gale, Hoyt S.

433. Coal fields of northwestern Colorado and northeastern Utah.-U. S. Geol. Survey, Bull. 341, pp. 283-315, 5 pls: (maps), 1 fig., 1909.

Describes the general stratigraphy and structure of the region, the occurrence, character, and relations of the coal-bearing formations, and the distribution and character of the coals.

Gannett, Henry.

434. Estimates of future coal production.-U. S., Geol. Survey, Bull. 394, pp. 27-29, 1909. Rept. Nat. Conservation Comm. (60th Cong., 2d sess., Sen. Doc. no. 676), vol. 3, pp. 443-445, 1909.

Ganong, W. F.

435. Notes on the natural history and physiography of New Brunswick. -New Brunswick Nat. Hist. Soc., Bull., no. 27 (vol. 6, pt. 2), pp. 85-109, 1 map, 1909.

Gardner, James H.

436. The coal field between Gallina and Raton Spring, New Mexico, in the San Juan coal region.-U. S. Geol. Survey, Bull. 341, pp. 335-351, 1 pl. (map), 1909.

Describes the geography, topography, and stratigraphy of the field and the occurrence relations, and character of the coal beds.

437. The coal field between Durango, Colorado, and Monero, New Mexico.-U. S. Geol. Survey, Bull. 341, pp. 352-363, 1 pl. (map), 1909.

Describes the stratigraphy and structure of the field, the occurrence, character, and relations of the coal beds, and the composition of the coals.

438. The coal field between Gallup and San Mateo, New Mexico.-U. S. Geol. Survey, Bull. 341, pp. 364-378, 1 pl. (map), 1909.

Describes the topography and geology of the field and the occurrence, character, and relations of the coal beds. 
Garrison, F. Lynwood.

439. Ores formed by magmatic segregation.-Min. and Sci. Press, vol. 98, pp. 451-456, March 27, 1909.

440. Nature of gold in alluvials.-Min. and Sci. Press, vol. 98, pp. 760-762, May 29, 1909.

Geddes, Charles Walter.

441. Calabacillas gold mine [Chihuahua, Mexico].-Min. and Sci. Press, vol. 98, pp. 689-690, 1 fig., May 15, 1909.

Includes a brief account of the local geology and of the occurrence of the gold ores.

Gehrmann, Charles A.

442. The gold camp of Rawhide, Esmeralda County, Nevada.-Min. Science, vol. 57, pp. 305-306, March 19, 1908.

George, R. D.

443. The main tungsten area of Boulder County, Colorado.-Colorado Sci. Soc., Proc., vol. 9, pp. 181-216, 1 pl., 4 figs., 2 maps, 1909.

Describes the general geology of the region, the lithology, the character and occurrence of tungsten ores, and the relations and origin of the ore bodies.

444. First report, 1908, with accompanying papers, Colorado Geol. Survey, Denver, 1909. 243 pp., 22 pls., 4 maps.

445. The main tungsten area of Boulder County, Colorado, with notes on the intrusive rocks by R. D. Crawford.-Colorado Geol. Survey, 1st Rept., 1908, pp. 7-103, 11 pls., 1909.

Describes the general geology and character of the rocks of the area, the occurrence and characters of tungsten minerals, and the occurrence, relations, and mining of tungsten ores in Boulder County, Colo.

George, R. D., and Crawford, R. D.

446. The Hahns Peak region, Routt County, Colorado. An outline survey.-Colorado Geol. Survey, 1st Rept., 1908, pp. 189-229, 1 pl., 1909.

Describes the general features of the region, the occurrence, character, and relations of pre-Cambrian, Carboniferous, Triassic, Cretaceous, and Tertiary formations, and igneous rocks, and the economic geology.

Gibson, Thomas W.

447. Report of the Bureau of Mines, 1909.-Ontario, Bureau of Mines, Eighteenth Ann. Rept., vol. 18, pt. 1, 311 pp., illus., Toronto, 1909.

Gidley, James Williams.

448. Notes on the fossil mammalian genus Ptilodus, with descriptions of new species.-U. S. Nat. Mus., Proc., vol. 36, pp. 611-636, 1 pl., 9 figs., 1909.

Gilbert, Grove Karl.

449. The California earthquake of 1906.-Am. Jour. Sci., 4th ser., vol. 27, pp. 48-52, January, 1909.

A review of the report of the California State Earthquake Investigation Commission published by the Carnegie Institution of Washington.

450. Earthquake forecasts.-Science, new ser., vol. 29, pp. 121-138, January 22, 1909. Min. and Sci. Press, vol. 98, pp. 183-186, January 30, 1909.

451. The convexity of hilltops.-Jour. Geology, vol. 17, no. 4, pp. 344-350, 5 figs., 1909.

Explains the convexity of hilltops as due to the action of creep.

Gill, H. V.

452. On a possible connexion between the eruption of Vesuvius and the earthquake at San Francisco in April, 1906.-Roy. Dublin Soc., Sci. Proc., new ser., vol. 11, no. 11, pp. 107-110, June, 1906. 
Gilmore, Charles W.

453. Osteology of the Jurassic reptile Camptosaurus, with a revision of the species of the genus, and descriptions of two new species.-U. S. Nat. Mus., Proc., vol. 36, pp. 197-332, 15 pls., 47 figs., 1909.

454. A new rhynchocephalian reptile from the Jurassic of Wyoming, with notes on the fauna of "Quarry 9."-U. S. Nat. Mus., Proc., vol. 37, pp. 35-42, 1 pl., 3 figs., 1909.

Describes Opisthias rarus $\mathrm{n}$. gen. and n. sp. from Como Bluff, Albany County, Wyo., and gives a list of vertebrate fossils from the same locality and notes upon some of them.

Girty, George H.

455. Upper Carboniferous.-Jour. Geology, vol. 17, no. 4, pp. 305-319, 1909.

Discusses the relations of upper Carboniferous faunas and the correlations of Carboniferous and so-called Permian formations.

456. The Guadalupian fauna and new stratigraphic evidence.-New York Acad. Sci., Annals, vol. 19, pt. 1, pp. 135-147, 1909.

Discusses the correlation and stratigraphic position of the beds containing the Guadalupian fauna.

457. The fauna of the Caney shale of Oklahoma.-U. S. Geol. Survey, Bull. 377, 106 pp., 13 pls., 1909.

Discusses the stratigraphic relations of the Caney shale and gives systematic descriptions and figures of the invertebrate fauna.

458. Paleontology of the Manzano group of the Rio Grande valley, New Mexico.U. S. Geol. Survey, Bull. 389, pp. 41-136, 7 pls., 1909.

Goldschmidt, V., and Mauritz, B.

459. Ueber Kalomel.-Zeitschr. Krystal. und Mineral., Bd. 44, pp. 393-406, 2 pls., 1908.

Describes the crystallography of calomel from Terlingua, Tex.

Goldthwait, James Walter.

460. Intercision, a peculiar kind of modification of drainage.-School Science and Mathematics, vol. 8, no. 2, pp. 129-139, 3 figs., February, 1908.

461. Physical features of the Des Plaines Valley.-Illinois State Geol. Survey, Bull. no. 11, 103 pp., 9 pls., 21 figs., 1909.

462. Isobases of post-Algonquin elevation across Lakes Michigan and Huron.Abstract: Science, new ser., vol. 29, p. 754, May 7, 1909.

Goldthwait, J. W., and Jacobson, R. C.

463. Preliminary report on measurements of altitude of the Algonquin and Nipissing shorelines in Ontario.-Canada, Geol. Survey, Summ. Rept., 1908, pp. 112-114, 1909.

Gordon, C. E.

464. Some geological problems.-Science, new ser., vol. 29, pp. 901-903, 1 fig., June 4, 1909.

Discusses the age, relations, and occurrence of metamorphosed pre-Cambrian and Cambrian sediments in New York and adjoining States.

Gordon, Charles $\mathrm{H}$.

465. The chalk formations of northeast Texas.-Am. Jour. Sci., 4th ser., vol. 27, pp. 369-373, May, 1909. Abstract: Science, new ser., vol. 29, p. 629, April 16, 1909.

Discusses the occurrence of chalk beds, to which the formation name Annona chalk has been given, in northeast Texas, and considers them to be the equivalent of the upper part of the Austin chalk of central Texas.

466. The red beds of the Wichita-Brazos region of north Texas.-Abstract: Science, new ser., vol. 29, p. 752, May 7, 1909. 
Gould, Charles N.

467. Extent and importance of Oklahoma gypsum deposits.-Min. Science, vol. 56, pp. 542-543, 583-584, December 12 and 19, 1907; vol. 57, pp. 73-74, January 16, 1908.

468. Asphalt in Oklahoma.-Min. Science, vol. 58, p. 427, November 26, 1908.

469. Asphalt deposits of Oklahoma.-Min. World, vol. 30, p. 84, January 16, 1909.

470. The Oklahoma coal fields.-Mines and Minerals, vol. 29, pp. 275-276, January, 1909.

Grabau, Amadeus W.

471. A revised classification of the North American lower Paleozoic.-Science, new ser., vol. 29, pp. 351-356, February 26, 1909.

472. Physical and faunal evolution of North America during Ordovicic, Siluric, and early Devonic time.-Jour. Geology, vol. 17, no. 3, pp. 209-252, 11 figs., 1909.

473. Tertiary drainage problems of eastern North America.-Abstract: Science, new ser., vol. 29, p. 632, April 16, 1909.

474. Some new or little-known geological terms and their application in stratigraphic writing.-Abstract: Science, new ser., vol. 29, p. 750, May 7, 1909.

475. Early developmental stages in recent and fossil corals.-Abstract: Science, new ser., vol. 29, p. 917, June 4, 1909.

476. The Medina and Shawangunk problems in Pennsylvania.-Abstract: Science, new ser., vol. 30, p. 415, September 24, 1909.

Discusses the age and mode of formation of Ordovician and Silurian formations in Pennsylvania.

Nomenclature and subdivision of the upper Siluric strata of Michigan, Ohio, and western New York.-See Lane and others, no. 733.

New upper Siluric fauna from southern Michigan.-See Sherzer and Grabau, no. 1058.

Grabau, Amadeus W., and Shimer, Hervey Woodburn.

477. North American index fossils: Invertebrates. New York, A. G. Seiler \& Company, 1909. Vol. I, Protozoa, Porifera, Hydrozoa, Anthozoa, Bryozoa, Brachiopoda, Pelecypoda, Scaphopoda, and Gastropoda, viii, 853 pp., 1210 figs.

Gives brief descriptions, usually with figures, and geologic horizon and distribution of characteristic fossils. Includes keys to the genera and species and references to the more important literature.

Graham, Richard P. D.

478. Dawsonite, a carbonate of soda and alumina.-Roy. Soc. Canada, Proc. and Trans., 3d ser., vol. 2, sect. 4, pp. 165-177, 4 figs., 1909.

Describes the occurrence, crystallography and optical properties, and the composition.

479. On a preliminary survey of the geology of the British Columbia coast from Kingcome Inlet to Dean Channel, including the adjacent islands.Canada, Geol. Survey, Summ. Rept., 1908, pp. 38-40, 1909. British Columbia, Ann. Rept. Minister of Mines, 1908, pp. 155-157, 1909.

480. On the optical properties of hastingsite from Dungannon, Hastings County, Ontario.-Am. Jour. Sci., 4th ser., 'vol. 28, pp. 540-543, December, 1909.

Grandin, M. V.

481. Notes on the ore deposits of South Cheticamp, Cape Breton Island, N. S.Nova Scotian Inst. Sci., Proc. and Trans., vol. 11, pt. 3; pp. 347-360, 1 pl., 1908.

Deseribes the general geology of the South Cheticamp mining district and the occurrence, relations, and character of copper and other ores. 
Granger, Walter.

482. Faunal horizons of the Washakie formation of southern Wyoming.-Am. Mus.

Nat. Hist., Bull., vol. 26, pp. 13-23, 5 pls., 2 figs., 1909.

Gives an historical review of previous work on the Washakie formations and the views entertained as to its age, relations, and deposition, describes the topography and geology with sections, and indicates the faunal horizons.

Grant, Ulysses Sherman.

483. The eastern limit of glacial Lake Agassiz.-Abstract: Minnesota Acad. Sci., Bull., vol. 4, no. 2, pp. 208-209, 1906.

484. Gold on Prince William Sound, Alaska.-U. S. Geol. Survey, Bull. 379, p. 97, 1909.

Grant, U. S., and Higgins, D: F., jr.

485. Copper mining and prospecting on Prince William Sound, Alaska.-U. S. Geol. Survey, Bull. 379, pp. 87-96, 1 pl. (map), 1909.

486. Notes on the geology and mineral prospects in the vicinity of Seward, Kenai Peninsula, Alaska.-U. S. Geol. Survey, Bull. 379, pp. 98-107, 1 fig., 1909.

Grasty, J. S.

The character and structural relations of the limestones of the Piedmont in Maryland and Virginia.--See Mathews and Grasty, no. 825.

Gratacap, Louis P.

487. Geology of the City of New York. Third edition. New York, Henry Holt and Company, 1909. x, 232 pp., 4 maps, 65 figs.

488. Growth of the Bement collection of minerals.-Min. World, vol. 30, pp. 673675, 1 pl., April 10, 1909.

Gray, F. W.

489. The mining operations of the Dominion Coal Company.-Canadian Min. Jour., vol. 30, pp. 10-16, 117-182, 235-237, 1909.

Includes notes on the geologic relations and occurrence of the coal deposits of Cape Breton Island, Nova Scotia.

Greene, F. C.

490. Caves and cave formations of the Mitchell limestone.-Indiana Acad. Sci., Proc., 1908, pp. 175-184, 1909.

Greger, Darling K.

491. The Devonian of central Missouri.-Am. Jour. Sci., 4th ser., vol. 27, pp. 374-378, May, 1909.

Describes the distribution and gives lists of fossils from the two formations represented.

Gregory, Herbert E.

492. Memoir of Angelo Heilprin [1853-1907].-Geol. Soc. America, Bull., vol. 19, pp. 527-536, 1 pl. (port.), 1909 .

A sketch of his life and a list of his writings.

493. Underground water resources of Connecticut; with a study of the occurrence of water in crystalline rocks, by E. E. Ellis.-U. S. Geol. Survey, WaterSupply Paper 232, 200 pp., 5 pls., 31 figs., 1909.

Gives a general account of the physiographic features and descriptive geology and, in more detail, of the occurrence, character, and recovery of the underground waters.

Gregory, J. W.

494. Catalogue of the fossil Bryozoa in the Department of Geology, British Museum (Natural History). The Cretaceous Bryozoa, vol. 2. London, 1909. $346 \cdot \mathrm{pp} ., 9$ pls.

Includes notes and figures of American forms from various horizons and descriptions of some species from the Cretaceous of New Jersey. 
Griggs, Robert $\mathrm{F}$.

495. Divided lakes in western Minnesota.-Am. Jour. Sci., 4th ser., vol. 27, pp. 388-392, 4 figs., May, 1909.

Explains the formation by ice action of narrow ridges dividing lakes.

Grimsley, G. P.

496. Iron ores, salt, and sandstones.-West Virginia Geol. Survey, vol. 4, 603 pp., 24 pls., 16 figs., 1909.

Grosspietsch, Oskar.

497. Krystallform und optische Orientierung des Albit von Morro Velho und Grönland.-Tschermaks Mineral. und Petrog. Mitt., Bd. 27, pp. 353-376, 8 figs., 1908.

Describes the crystallography of albite from Greenland.

Grout, Frank F.

498. The classification of geologic materials.-Econ. Geology, vol. 4, no. 7, pp. 646-653, 1909.

499. The classification of coal.-Econ. Geology, vol. 4, no. 7, pp. 653-658, 1909.

Gulliver, F. P.

500. Nantucket shore lines, IV.-Abstract: Science, new ser., vol. 29, p. 633, April 16, 1909.

501. The American Association for the Advancement of Science. Section E, Geology and geography.-Science, new ser., vol. 29, pp. 747-757, May 7, 1909 .

Gives an account of the meeting at Baltimore, December, 1908, and abstracts of papers presented.

\section{Gunter, Herman.}

The fuller's earth deposits of Gadsden County, Florida.-See Sellards and Gunter, no. 1050.

Guppy, R. J. Lechmere.

502. The geological connections of the Caribbean region.-Canadian Inst., Trans., vol. 8, pt. 3, pp. 373-391, 1 map, April, 1.909.

Discusses evidence for the pre-Miocene distribution of land in the Caribbean sea.

Haley, D. F.

503. The auriferous antimony ore of West Gore, Nova Scotia.-Eng. and Min. Jour., vol. 88, pp. 723-724, 1 fig., October 9, 1909.

Includes notes on the local geology and the occurrence of the ores.

Hall, Edward Hagaman.

504. The Palisades of the Hudson River, the story of their origin, attempted destruction, and rescue.-11th Ann. Rept., 1906, of the Am. Scenic and Historic Preservation Soc., Albany, 1906, pp. 191-212, 1 pl. (in Documents of the Assembly of the State of New York, 129th sess., 1906, vol. 12, no. 74).

Hamilton, S. Harbert.

505. Notes on some ore deposits of Porto Rico.-Eng. and Min. Jour., vol. 88, pp. 518-519, 2 figs., September 11, 1909.

Includes notes on the geology and the occurrence of iron, copper, and other ores and minerals.

Haney, Marshall.

506. Copper deposits of Greene County, Virginia.-Eng. and Min. Jour., vol. 88, p. 1286, December 25, 1909. 
Hannibal, Harold.

507. A new Carinifex [sanctrelaræe n. sp.] from the Santa Clara lake beds (Pliocene), California.-Nautilus, vol. 23, pp. 40-41., July, 1909.

Hantzsch, Bernhard.

508. Beiträge zur Kenntniss des nordöstlichsten Labradors.-Ver. Erdk., Dresden, Mitt., Heft 8, pp. 168-229, 1909.

A description of northeastern Labrador. Includes notes on the geology and physiographic features.

Harder, Edmund Cecil.

509. The Taylor Peak and Whitepine iron-ore deposits, Colorado.-U. S. Geol. Survey, Bull. 380, pp. 188-198, 4 figs., 1909.

Describes the local geology and the structure of the ore deposits.

510. The iron ores of the Appalachian region in Virginia.-U. S. Geol. Survey, Bull. 380, pp. 215-254, 8 figs., 1909.

Describes the character, composition, geographic distribution, and geologic relations of the various types of iron ore found in Virginia.

511. Manganese deposits of the United States.-U. S. Geol. Survey, Bull. 380, pp. 255-277, 1909.

Mineral resources of the United States, 1908: Iron ores, pig iron, and steel; manganese ores; chromic iron ore.-See no. 1170.

Harris, Gilbert Dennison.

512. The geological occurrence of rock salt in Louisiana and east Texas.-Econ. Geology, vol. 4, no. 1, pp. 12-34, 2.pls., 7 figs., 1909.

513. Magnetic rocks.-Science, new ser., vol. 29, p. 384, March 5, 1909.

Calls attention to the fact that the peridotite eruptives about Murfreesboro, Ark., are magnetic, and to the practical bearing of this fact.

Harris, G. D., Perrine, I., and Hopper, W. E.

514. Oil and gas in northwestern Louisiana with special reference to the Caddo field.-Louisiana Geol. Survey, Bull. no. 8, 52 pp., 6 figs., 1909.

Harrison, Alfred C., and others.

515. Persifor Frazer, 1844-1909.-Franklin Inst., Jour., vol. 168, pp. 75-79, 1 pl. (port.), July, 1909.

A sketch of his life.

Hastings, John B.

516. Meteor Crater [Arizona].-Min. and Sci. Press, vol. 98, pp. 523-525, 2 figs, April 10, 1909.

Primary gold in a Colorado granite.-Am. Inst. Min. Eng., Trans., vol. 39, pp. 97-103, 1 fig., 1909. See no. 441 of the bibliography for 1908, U. S. Geol. Survey, Bull. 409, p. 41.

Origin of pegmatite.-Am. Inst. Min. Eng., Trans., vol. 39, pp. 105-128, 1909.. See no. 442 of the bibliography for 1908, U. S. Geol. Survey, Bull. 409, p. 41.

Volcanic waters.-Am. Inst. Min. Eng., Trans., vol. 39, pp. 129-138, 1909.

See no. 413 of the bibliography for 1908, U. S. Geol. Survey, Bull.409, p. 41.

Haworth, Erasmus; and Bennett, John.

517. History of [geological] fieldwork [in Kansas].-Kansas, Univ. Geol. Survey, vol. 9 , pp. 42-56, 1908.

518. General stratigraphy [of Kansas].-Kansas, Univ. Geol. Survey, vol. 9, pp. 57-121, 1908:

Discusses the nomenclature, synonymy, areal distribution, characters, and relations of the Carboniferous formations of Kansas.

$56693^{\circ}-$ Bull. $444-10-4$ 
Haworth, Erasmus, and others.

519. Special report on oil and gas.-Kansas, Univ. Geol. Survey, vol. 9, 586 pp., 107 pls., 2 maps, 8 figs., 1908.

Includes chapters on discoveries of oil and gas, geographical and historical, detailed geology of oil and gas, life of oil wells and gas wells, commercial conditions of oil and gas, chemical composition of gas, and chemical composition of petroleum.

Hay, Oliver Perry.

520. On the skull and the brain of Triceratops, with notes on the brain cases of Iguanodon and Megalosaurus.-U. S. Nat. Mus., Proc., vol. 36, pp. 95108, 3 pls., 1909. Abstract: Science, new ser., vol. 29, p. 713, April 30, 1909.

521. Description of two species of fossil turtles, Toxochelys stenopora and Chisternon? interpositum, the latter hitherto unknown.-U. S. Nat. Mus., Proc., vol. 36, pp. 191-196, 1 pl., 3 figs., 1909.

522. Dr. Williston on "The fossil turtles of North America."-Science, new ser., vol. 29, pp. 341-342, February 26, 1909.

Gives various notes upon fossil turtles.

523. On the restoration of skeletons of fossil vertebrates.-Science, new ser., vol. 30, pp. 93-95, July 16, 1909.

524. The geological and geographical distribution of some Pleistocene mammals.Science, new ser., vol. 30, pp. 890-893, December17, 1909.

Hayes, Charles Willard.

525. Handbook for field geologists. Second edition, thoroughly revised. New York, John Wiley \& Sons, 1909 . ix, 159 pp., 18 figs.

The first edition bearing title, Handbook for field geologists in the United States Geological Survey, 159 pp., 11 figs., was issued by the Survey in 1908 for official use.

526. The iron-ore supply of the United States.-Am. Inst. Min. Eng., Bull., no. 28, pp. 373-379, April, 1909.

527. Contributions to economic geology, 1908. Part I. Introduction.-U. S. Geol. Survey, Bull. 380, pp. 7-11, 1909.

Contributions to economic geology, 1908. Part I. Metals and nonmetals, except fuels.-See no. 1169.

528. Investigations relating to nonmetallic mineral resources and iron ores.U. S. Geol. Survey, Bull. 380, pp. 12-15, 1909.

Outlines the progress of investigations by the United States Geological Survey during the year 1908 and gives a list of publications issued in 1908 on nonmetallic mineral resources and iron ores.

529. Iron ores of the United States.-U. S. Geol. Survey, Bull. 394, pp. 70-113, 1 fig., 1909. Rept. Nat. Conservation Comm. (60th Cong., $2 \mathrm{~d}$ sess., Sen. Doc. no. 676), vol. 3, pp. 483-520, 1 fig., 1909. Abstract: Min. and Sci. Press, vol. 98, pp. 798-799, June 5, 1909.

Hayes, C. W., and Lindgren, Waldemar.

Contributions to economic geology, 1908. Part I. Metals and nonmetals, except fuels.-U. S. Geol. Survey, Bull. 380,399 pp., 2 pls., 32 figs., 1909.

Hayford, John F.

530. The figure of the earth and isostasy from measurements in the United States.U. S. Coast and Geodetic Survey, Washington, 1909, 178 pp., 6 pls., 11 figs.

531. Results of a geodetic study of the San Francisco earthquake.-Abstract: Science, new ser., vol. 29, p. 199, January 29, 1909. 
Headden, William P.

532. The brown artesian waters of Costilla County, Colorado, their relations to certain deposits of natron or soda, and what they teach.-Am. Jour. Sci., 4th ser., vol. 27, pp. 305-315, April, 1909.

533. Notes on some mineral springs.-Colorado Sci. Soc., Proc., vol. 9, pp. 259272, December, 1909.

Gives analyses and descriptive notes upon springs in Platte Canyon and in Delta County, Colo.

Hedburg, Edward.

534. The Calizona placers, Arizona.-Min. World, vol. 31, p. 138, July 10, 1909.

535. The Greens Valley mining district, Arizona.-Min. World, vol. 31, pp. 12451246, 3 figs., December 25, 1909.

Includes notes on the local geology and the occurrence of gold ores.

Henderson, Junius.

536. The foothills formations of north central Colorado.-Colorado Geol. Survey, 1st Rept., 1908, pp. 145-188, 6 pls., 1909.

Describes the general geologic structure and the distribution and relations of pre-Carboniferous, Carboniferous, Permo-Triassic?, Jurassic, and Cretaceous formations.

Hennen, Ray V.

537. Marshall, Wetzel, and Tyler counties [West Virginia].-West Virginia Geol. Survey, County Reports, Marshall, Wetzel, and Tyler counties, 654 pp., 12 pls., 3 figs., 3 maps (in atlas), 1909.

Describes the history, physiography, and geology of the Marshall-Wetzel-Tyler area of West Virginia, and the mineral resources, including petroleum, natural gas, coal, clays, road materials, and building stones.

\section{Henning, Karl L.}

538. Streifzüge in den Rocky Mountains.-Globus, Bd. 92, pp. 25-29, 46-49, 101107, 10 figs.; 1907; Bd. 93, pp. 312-318, 5 figs., 1908.

Describes excursions in the Rocky Mountains in Colorado. Includes notes on physiographic features and the geology.

539. Streifzüge in den Rocky Mountains. IV. Morrison und die Morrisonformation.-Globus, Bd. 96, Nr. 22, pp. 344-349, 5 figs., December 16, 1909.

Describes the region around Morrison, Colo., the red beds and the Morrison formation.

\section{Henshaw, Fred F.}

540. Mining in the Fairhaven precinct, Alaska.-U. S. Geol. Survey, Bull. 379, pp. 355-369; 1 fig., 1909.

Describes gold deposits and the occurrence of coal.

\section{Hermann, A.}

541. Modern laboratory methods in vertebrate paleontology.-Am. Mus. Nat. Hist., Bull:, vol. 26, pp. 283-331, 6 pls., 18 figs., 1909.

Herrick, R. L.

542. The Alice mine, Colorado's largest ore body, situated in the Fall River district, Colorado.-Mines and Minerals, vol. 29, pp. 294-296, 4 figs., Feb- ruary, 1909.

Includes notes upon the geology of the ore body.

543. El Tigre mine, district of Montezuma, Sonora, Mexico.-Mines and Minerals, vol. 29 , pp. 483-487, 3 figs., June, 1909.

Includes an account of the local geology and the occurrence and character of the gold and silver ores.

544. Ray consolidated mines, a low-grade copper property at Ray, Ariz.-Mines and Minerals, vol. 29; pp. 544-547, 3 figs., July, 1909.

Includes notes on the geology; character, and occurrence of the ores. 
Herrick, R. L.-Continued.

545. The Miami copper mine, Arizona.-Mines and Minerals, vol. 30, pp. 80-84, 7 figs., September, 1909.

Includes an account of the geology of the vicinity of Globe, Ariz., and the occurrence and character of the copper deposits.

\section{Hershey, Oscar H.}

546. The ancient Kobuk glacier of Alaska.-Jour. Geology, vol. 17, no. 1, pp. 83-91, 1909.

547. Black Diamond.-Min. and Sci. Press, vol. 98, p. 147, January 23, 1909. Includes notes on the local geology of a prospect in Del Norte County, Cal.

Herzig, C. S.

548. What is an ore?-Min. and Sci. Press, vol. 99, pp. 117-119, July 24, 1909.

Hess, Frank L.

549. Tin, tungsten, and tantalum deposits of South Dakota.--U. S. Geol. Survey, Bull. 380, pp. 131-161, 1 fig., 1909.

550. Notes on a wolframite deposit in the Whetstone Mountains, Arizona.-U. S. Geol. Survey, Bull. 380, pp. 164-165, 1909.

Describes the occurrence and character.

551. Texas celestite deposits.-Eng. and Min. Jour., vol. 88, p. 117, 1 fig., July 17, 1909.

552. Graphite mining near La Colorado, Sonora, Mexico.--Eng. Mag., vol. 38, no. 1, pp. 36-48, 9 figs., October, 1909.

Describes the general geology and the occurrence, character, and origin of the graphite.

553. The Santa Maria graphite deposits, Mexico.-Min. World, vol. 31, pp. 10781080, November 27, 1909.

554. The Santa Maria graphite mines.-Abstract: Science, new ser., vol. 30, p. 125, July 23, 1909.

Mineral resources of the United States, 1908: Antimony; bismuth; selenium, tellurium; tungsten, nickel, cobalt, vanadium, etc.; tin; arsenic.-See no. 1170 .

Hice; Richard R.

555. The preglacial drainage of western Pennsylvania.-Abstract: Science, new ser., v́ol. 29, p. 40, January 1, 1909.

Higgins, D. E., jr.

Copper mining and prospecting on Prince William Sound, Alaska.--See Grant and Higgins, no. 485.

Notes on the geology and mineral prospects in the vicinity of Seward, Kenai Peninsula, Alaska.-See Grant and Higgins, no. 486.

Higgins, Edwin.

556. Iron operations in the Chattanooga district.-Eng. and Min. Jour., vol. 87, pp. 1-5, 9 figs., January 2, 1909.

Includes notes on the geology and the occurrence and character of the iron ores.

557. Operations in the Cobalt district, Ontario.--Eng. and Min. Jour., yol. 87, pp. 1267-1272, 9 figs., June 26, 1909.

Includes a brief account of the geology of the district and of the occurrence and character of the silver deposits.

Higgins, Will $\mathrm{C}$.

558. The Sevier Consolidated mine of Gold Mountain, Piute County, Utah.-Salt Lake Min. Rev., vol. 11, no. 3, pp. 15-18, 5 figs., May 15, 1909.

Includes a short account of the local geology and the character and occurrence of the gold ores. 
Higgins, Will C.-Continued.

559. Napoleon-Maghera mines in Sierra Madre Mountains, Box Elder County, Utah.-Salt Lake Min. Rev., vol. 11, no. 14, pp. 19-23, 7 figs., October 30, 1909.

Includes notes on the local geology and the ore deposits producing copper, gold, and silver.

560. The Century and the Susannah mines, Golden, Utah.-Salt Lake Min. Rev., vol. 11, no. 16, pp. 19-22, 4 figs., November 30, 1909.

Includes notes on the local geology and the occurrence of the gold ore.

Hijar y Haro, Luis.

561. Apuntes sobre los yacimientos minerales de Campo Morado en el distrito de Aldama, Estado de Guerrero, México.-Soc. cient. "Antonio Alzate," Mem. y Rev., t. 25, nos. 5-8, pp. 245-252, 2 figs., 1908.

Describes pyritiferous deposits yielding chiefly iron, with small amounts of lead, copper, silver, and gold.

Hill, J. M.

562. Notes on the economic geology of southeastern Gunnison County, Colorado.-

U. S. Geol. Survey, Bull. 380, pp. 21-40, 1 pl. (map), 1 fig., 1909.

Describes the general features, the stratigraphy and geologic structure, and the mineral resources, chiefly gold and silver, and mining developments.

Hill, Robert T.

563. The chalk formations of northeast Texas.-Science, new ser., vol. 29 , pp. 972-973, June 18, 1909.

Hille, F.

564. Report on the examination of some iron-ore deposits in the districts of Thunder Bay and Rainy River, Province of Ontario.-The Iron Trade. Review, vol. 45, pp. 497-501, 3 figs., September 16, 1909.

Hillebrand, W. F., and Schaller, W. T.

565. The mercury minerals from Terlingua, Texas.-U. S. Geol. Survey, Bull. 405, 174 pp., 6 pls., 44 figs., 1909.

Describes the occurrence and associations of the minerals and their physical properties, composition, and crystallography.

Hills, B. W.

566. The molybdenite deposits of Tunk Pond, Maine.-Min. World, vol. 31, pp. 323-324, August 7, 1909.

Hills, Victor G.

567. What is an ore?-Min. and Sci. Press, vol. 98, pp. 582-583, April 24, 1909.

Discusses the definition of this term.

568. Tungsten mining and milling.-Colorado Sci Soc., Proc., vol. 9, pp. 135-153, 1 pl., April, 1909. Min. World, vol. 30, pp. 1021-1024, 1 fig., May 29, 1909.

Includes notes on the occurrence of tungsten ores in Colorado.

Hind, Henry Youle.

569. Riviere du Loup goldfields, townships of Jersey and Liniere, Beauce County,

Quebec. Notes and extracts from a special report by. Dr. Henry Youle Hind, published in the year 1864.-Canadian Min. Jour., vol. 30, pp. 618-619, 682-683, 1909.

Hindry, W. E.

570. The Esperanza mine, El Oro, Mexico.-Min. Mag., London, vol. 1, pp. 131138, 6 figs., October, 1909.

Includes notes on the geology and occurrence of the gold ores. 
Hinds, Henry.

571. The coal deposits of Iowa.-Iowa Geol. Survey, vol. 19, pp. 21-396, 9 pls., $1(12$ figs., 1909:

Hitchcock, Charles H.

572. Hawaii and its volcanoes. Honolulu, Hawaii, the Hawaiian Gazette Company, 1909. $314 \mathrm{pp} ., 52 \mathrm{pls}$.

573. The volcano Kilauea.-Am. Geog. Soc., Bull., vol. 41, no. 11, pp. 684-691, 4 figs., November, 1909.

Describes briefly the history of the volcano Kilauea and its recent activity.

Hixon, Hiram W.

574. The relation of magmatic waters to volcanic action.-Franklin Inst., Jour., vol. 165, pp. 297-307, 1 fig., October, 1908.

575. Earthquakes in the light of the new seismology.-Franklin Inst., Jour., vol. 168, pp. 227-234, 3 figs., September, 1909.

576. [Origin of the Sudbury, Ontario, ores.]-Inst. Min. and Metal., London, Trans., vol. 18, pp. 196-198, 1909.

577. A theory of volcanic action and ore deposits, their nature and cause.-Inst. Min. and Metal., London, Trans., vol. 18, pp. 202-219, 231-254, 1 fig., 1909.

Hixson, A. W.

Analyses of Iowa coals.-See Lees and Hixson, no. 754 .

Hawatsch, C.

578. Bemerkungen über den Benitoit.-Zeitschr. Krystal. und Mineral., Bd. 46, Heft 6, pp. 602-603, 1909.

Gives observations upon benitoite.

579. Die Kristallform des Benitoit.-Centralbl. Mineral., Geol., und Paläont., Jg. 1909, no. 10, pp. 293-302, 3 figs., no. 13, p. 410, 1909.

Describes the crystallography of benitoite from California.

580. Bemerkungen über die Krystallklasse des Benitoit.-Tschermaks Mineral. und Petrog. Mitt., N. F., Bd. 28, pp. 178-181, 2 figs., 1909.

Observations upon the class of crystals to which benitoite belongs.

581. Bemerkungen zum Aragonit von Rohitsch, Natrolit, und Neptunit von S. Benito.-Tschermaks Mineral. und Petrogr. Mitt., N. F., Bd. 28, pp. 293-296, 1909.

Gives notes upon natrolite and neptunite from San Benito, Cal.

Hobbs, William Herbert.

582. The evolution and the outlook of seismic geology.-Am. Philos. Soc., Proc., vol. 48, pp. 259-302, 2 pls., 8 figs., 1909. Abstract: Science; new ser., vol. 29, p. 833, May 21, 1909.

Discusses the causes of earthquakes and the possibilities of prognostication.

683. Apparatus for instruction in geography and structural geology.-School Science and Mathematics, vól. 8, pp. 566-570, 662-668, 10 figs., 1908; vol. 9, pp. 644-653, 8 figs., 1909.

584. New laboratory methods for instruction in geography.-Jour. Geog., vol. 7, no. 5, pp. 97-104, 5 figs., January, 1909.

585. Recent earth movements within the basin of the Laurentian lakes.-Abstract: British Assoc. Adv. Sci., Rept. 78th Meeting, p. 707, 1909.

Holland, W. J.

586. Deinosuchus hatcheri, a new genus and species of crocodile from the Judith River beds of Montana.-Carnegie Mus., Annals, vol. 6, no. 1, pp. 281294, 16 figs., August, 1909. 
Hollick, Arthur.

587. A new genus of fossil Fagaceæ from Colorado.-Torreya, vol. 9, no. 1, pp. 1-3,

2 figs., January, 1909.

Proposes the new generic name Fagopsis for the Planera longifolia Lesq., from the Miocene shales of Florissant, Colo.

Hollick, Arthur, and Jeffrey, Edward Charles.

588. Studies of Cretaceous coniferous remains from Kreischerville, New York.New York Bot. Garden, Mem., vol. 3, 138 pp., 29 pls., 1909.

Holway, R. S., and Linsley, Earle G.

589. A syllabus for the study of the physiographic provinces of California.-California Phys. Geog. Club, Bull., vol. 2, no. 2, pp. 11-20, March, 1909.

Hopkins, T. C., and Clark, B. W.

590. Laboratory manual in physical geography. Boston, Benj. H. Sanborn \& Co., 1909. $61 \mathrm{pp}$.

Hopper, W. E.

Oil and gas in northwestern Louisiana with special reference to the Caddo field.-See Harris, Perrine, and Hopper, no. 514.

Hore, R. E.

591. On the origin of cobalt-silver deposits of northern Ontario.-Canadian Min. Jour., vol. 30, pp. 118-120, February 15, 1909.

592. In the Michigan copper country.-Canadian Min. Jour., vol. 30, pp. 421-422, 7 figs., July 15, 1909.

Includes notes on the occurrence of the copper ores.

Hovey, Edmund Otis.

593. Striations and U-shaped valleys produced by other than glacial action.Geol. Soc. America, Bull., vol. 20, pp. 409-416, 5 pls., 1909. Abstract: Science, new ser., vol. 29, p. 633, April 16, 1909.

The discussion and illustrations relate to effects produced by the eruptions of Mont Pelé in Martinique and the Soufrière in St. Vincent in 1902 and 1903.

594. Earthquakes, their causes and effects.-Am. Philos. Soc., Proc., vol. 48, pp. 235-258, 1909. Abstract: Science, new ser., vol. 29, p. 833, May 21, 1909.

595. Proceedings of the twentieth annual meeting of the Geological Society of America, held at Albuquerque, New Mexico, December 30 and 31, including the proceedings of the ninth annual meeting of the Cordilleran section, held at the same place and time.-Geol. Soc. America, Bull., vol. 19, pp. 513-617, 9 pls., 1909.

Includes abstracts of papers and obituary notices.

596. The Geological Society of America.-Science, new ser., vol. 29, pp. 623-639, April 16, 1909.

Gives an account of the twenty-first annual meeting at Baltimore, December, 1908, and abstracts of papers presented.

597. Clearing out of the Wallibu and Rabaka gorges on Saint Vincent Island.Geol. Soc. America, Bull., vol. 20, pp. 417-426, 3 pls., 1909.

598. The Guffey, Colorado, meteorite.-Am. Mus. Jour., vol. 9, no. 8, pp. 237243, 5 figs., December, 1909.

Records the discovery and describes the surface features and composition of this siderite to which the name Guffey is given.

599. Recent additions to the meteorites in the foyer [of the American Museum of Natural History].-Am. Mus. Jour., vol. 9, no. 8, pp. 243-248, 3 figs., December, 1909. 
Hovey, Edmund Otis--Continued.

600. Camping on the Soufrière of St. Vincent.-Am. Geog. Soc., Bull., vol. 41, no. 2, pp. 72-83, 8 figs., February, 1909.

Includes notes on the physiographic features of the island.

601. St. Pierre and Mt. Pelé in 1908.-Am. Mus. Jour., vol. 9, no. 2, pp. 33-40, 5 pls., February; 1909.

602. Some of the latest results of explorations in the Hudson River at New York City.-Abstract: Science, new ser., vol. 29, p. 280, February 12, 1909.

Howe, Ernest.

603. Landslides in the San Juan Mountains, Colorado, including a consideration of their causes and their classification.-U. S. Geol. Survey, Prof. Paper 67, 58 pp., 20 pls., 4 figs., 1909.

Howley, James $\mathbf{P}$.

604. Coal areas of Newfoundland.-Canadian Min. Jour., vol. 30, pp. 455-461, 10 figs., August 1, 1909.

605. Geology and mineral resources of Newfoundland.-Min. World, vol. 31, pp. 701-704, 1 fig. [geol. map], October 2, 1909.

Hudson, George H.

606. Some items concerning a new and an old coast line of Lake Champlain.-New York State Mus., Bull. 133, pp. 159-163, 8 pls., 1909.

Proposes the term cup holes for shore-line excavations and discusses the position of shore lines of Lake Champlain.

Huene, F. v.

607. Skizze zu einer Systematik und Stammesgeschichte der Dinosaurier.Centralbl. Mineral., Geol., und Paläont., Jg. 1909, no. 1, pp. 12-22, 1909. Gives a classification and phylogeny of the Dinosauria. Includes $A$ merican forms.

Humphreys, Edwin W.

608. Recent fresh-water fossils from Bronx Borough, New York City.-Nautilus, vol. 23, pp. 10-11, May, 1909.

Hussakof, L.

609. The systematic relationships of certain American arthrodires.-Am. Mus. Nat. Hist., Bull., vol. 26, pp. 263-272, 1 pl., 8 figs., 1909.

Iddings, Joseph $\mathrm{P}$.

610. Igneous rocks, composition, texture and classification, description and occurrence. In two volumes. Vol. I, 464 pp., 3 pls., 130 figs. New York, John Wiley \& Sons, 1909:

611. The study of igneous rocks.-Science, new ser., vol. 29, pp. 201-217, February $5,1909$.

Thne, F. W.

612. Graphite in the United States.-Min. Science, vol. 60, pp. 297-298, 316-318, 343-346, 4 figs., 1909.

Illinois State Geological Survey.

Year-book for 1908. Bull. no. 14. Urbana, 1909 (1910). 394 pp., 5 pls., 5 figs.

The several papers in this report have been listed under the individual authors.

Ingall, E. D.

613. [Report of] Water and borings branch.-Canada Geol. Survey, Summ. Rept., 1908, pp. 159-161, 1909. 
Ingalls, A. $O$.

614. The geology of Washington, with an attempt to classify the vein system.Northwest Min. Jour., vol. 7, no. 5, pp. 51-53, June, 1909.

Ingalls, W. $R$.

The mineral wealth of the Cordilleras.-See Raymond and Ingalls, no. 986.

The mineral wealth of America.-See Raymond and Ingalls, no. 987.

Inkey, B. de.

615. Des volcans du Méxique.-Abrégé du Bull. de la Soc. Hongroise de Géog., Budapest (Suppl. to Földrajzi Közlemények, vol. 36, livr. 8-10), pp. 151-161, 6 figs., 1908.

Describes some of the volcanoes of Mexico.

Jacobson, R. C.

Preliminary report on measurements of altitude of the Algonquin and Nipissing shorelines in Ontario.-See Goldthwait and Jacobson, no. 463.

Jaggar, Thomas A., jr.

616. Report of the committee on earthquake and volcano observations.-Abstract: Science, new ser., vol. 29, pp. 630-631, April 16, 1909.

Jeffrey, Edward Charles.

617. Araucariopitys, a new genus of Araucarians.-Bot. Gazette, vol. 44, pp. 435444, 3 pls., December, 1907.

Describes A raucariopitys americana from Cretaceous deposits of Staten Islạnd, New York.

618. On the structure of the leaf in Cretaceous pines.-Annals of Botany, vol. 22, pp. 207-220, 2 pls., April, 1908.

Studies of Cretaceous coniferous remains from Kreisherville, New York.-See Hollick and Jeffrey, no. 588.

Jellum, S. P.

619. Central Idaho gold districts.-Northwest Min. News, vol. 3, pp. 83-91, 107-114, 134-139, vol. 4, pp. 2-6, 31-37, 66-73, illus., 1908-9.

Jenks, William.

620. Copper in sandstone.-Min. Science, vol. 58, pp. 150-151, 168-169, August 20 and $27,1908$.

Jenney, Walter P.

621. The Nevada meteorite. -Min. and Sci. Press, vol. 98, pp. 93-94, 2 figs., January 9, 1909 .

Describes the location where found, the general characters, and the fall.

622. The great Nevada meteor of 1894.-Am. Jour. Sci., 4th ser., vol. 28, pp. 431434, 2 figs., November, 1909.

Describes the Quinn Canyon, Nevada, meteorite, and a meteor from which the fall may have been derived.

623. Geology of the Manhattan district, Nevada.-Eng. and Min. Jour., vol. 88, pp. 82-83, July 10, 1909.

Discusses the geology of the district and the deposition of the ores.

624. Geological and physical conditions of Tonopah mines [Nevada].-Min. and Sci. Press, vol. 99, pp. 685-686, I fig., November 20, 1909.

Describes the geology of the district and the character and geologic relations of the ore bodies. 
Jennings, E. P.

625. The copper deposits of Yerington, Nevada.-Am. Min. Cong., 12th Ann. Sess., Rept. of Proc., pp. 423-427, 1909.

626. The localization of values in ore bodies and the occurrence of shoots in metalliferous deposits.-Econ. Geology, vol. 4, no. 3, pp. 255-257, 1909.

Jensen, Adolf Severin.

627. On the fossil Quaternary mollusc-fauna of Greenland.-Meddelelser om Groenland, H. 29, pp. 289-305, 1909.

Discusses climatic changes in Greenland in Quaternary time as evidenced by the distribution of certain mollusks.

Johnson, Alexander T.

628. Mining in the Tonopah district.-Am. Min. Cong., 12th Ann. Sess., Rept. of Proc., pp. 412-417, 1909.

Includes a brief account of the geology and occurrence of the ores.

Johnson, Douglas Wilson.

629. A geological excursion in the Grand Canyon district.-Boston Soc. Nat. Hist., Proc., vol. 34, no. 6, pp. 135-161, 6 pls., 13 figs., May, 1909.

Describes physiographic features and faulting in the Grand Canyon region.

630. Hanging valleys.-Am. Geog. Soc., Bull., vol. 41; no. 11, pp. 665-683, 13 figs., November, 1909.

Discusses the origin of hanging valleys with reference to glacial erosion.

Johnson, H. R.

631. Geology of the McKittrick-Sunset district, California.-Abstract: Science, new ser., vol. 30, pp. 63-64, July 9, 1909.

Describes the stratigraphic formations and the geologic structure of the area.

The earthquake rift in eastern San Luis Obispo County, California.-See Arnold and Johnson, no. 33 .

Sodium sulphate in Soda Lake, Carriso Plain, San Luis Obispo County, California.-See Arnold and Johnson, no. 34.

Johnston, Robt. A. A.

632. [Report of]. Section of mineralogy.-Canada, Geol. Survey, Summ. Rept., 1908, pp. 162-170, 1909.

Johnston, W. A.

633. Simcoe sheet, Ontario.-Canada, Geol. Survey, Summ. Rept., 1908, pp. 97102,1909 .

Discusses the correlation of the Ordovician formations of the area.

Jones, Charles Colcock.

634. An iron deposit in the California desert region.-Eng. and Min. Jour., vol. 87, pp. 785-788, 6 figs., April 17, 1909.

635. Notes on Manhattan placers, Nye County, Nevada.-Eng. and Min. Jour., vol. 88, pp. 101-104, 7 figs., July 17, 1909.

Includes notes on the geology of the district and the occurrence and character of the ore deposits and placer gravels.

Jones, Fayette A.

636. The new camp of Sylvanite, New Mexico.-Min. Science, vol. 58, pp. 489490, 3 figs., December 17, 1908.

Describes the geology and physiography of the Little Hatchet Mountains in Grant County, N. Mex., and the character and occurrence of the gold ores.

637. History and mining of turquoise in the Southwest.-Min. World, vol. 31, pp. 1251-1252, December 25, 1909.

Describes the occurrence of turquoise in New Mexico. 
Jones, S. P.

638. Second report on the gold deposits of Georgia.-Georgia, Geol. Survey, Bull. no. 19,283 pp., 8 pls., 2 maps, 1909.

Jordan, David Starr, and Clark, George Archibald.

639. The Bogoslofs.-Pop. Sci. Monthly, vol. 69, no. 6, pp. 481-489, 7 figs., December, 1906.

Judson, John N.

640. The Vermont Copper Company.-Eng. and Min. Jour., vol. 88, pp. 524-525. Includes notes on the character and composition of the ores.

Kaitz, F. J.

The Fairbanks gold placer region, Alaska.-See Prindle and Katz, no. 970.

Kay, G. F.

Mineral resources of the Grants Pass quadrangle and bordering districts, Oregon.-See Diller and Kay, no. 340 .

Keele, Joseph.

641. Explorations on the Pelly, Ross, and Gravel rivers, in the Yukon and Northwest territories.-Canada, Geol. Survey, Summ. Rept., 1908, pp. 33-37, 1909. Abstract: Min. and Sci. Press, vol. 99, p. 66, 1909.

Keith, Arthur.

642. The status of geologic names.-Abstract: Science, new ser., vol. 30, pp. 974975, December 31, 1909.

Discusses the nomenclature of geologic formations and the work of the committee on geologic names of the U. S. Geological Survey in systematizing existing chaotic conditions.

Kelly, William.

643. Discussion of paper by J. J. Rutledge on The Clinton iron-ore deposits of Stone Valley, Huntingdon County, Pa.-Am. Inst. Min. Eng., Bull., no. 25, pp. 107-108, January, 1909.

Kemp, James Furman.

644. What is an ore?-Min. and Sci. Press, vol. 98, pp. 419-423, March 20, 1909. Canadian Min. Jour., vol. 30, pp. 692-693, 752-754, 1909. Min. World, vol. 30, pp. 1111-1114, June 12, 1909.

Presents and discusses various definitions of the term "ore."

645. Spheroidal weathering of dikes.-Min. and Sci. Press, vol. 98, pp. 443-444, 1 fig., March 27, 1909.

646. Our knowledge of the filled channel of the Hudson in the Highlands and the submerged gorge on the continental shelf.-Abstract: Science, new ser., vol. 29, p. 279, February 12, 1909.

647. Review of The iron ores of the Iron Springs district in southern Utah, by C. K. Leith and E. C. Harder (Bull. 338, U. S. Geol. Survey).-Jour. Geology, vol. 4, no. 8, pp. 782-791, 1909.

Kempton, C. W.

648. Some investigations of Santo Domingo minerals.-Min. World, vol. 30, pp. 637-639, 8 figs., April 3, 1909.

Includes notes on the geology of the island and the occurrence of ores.

649. Mines and minerals in the New England States.-Min. World, vol. 30, pp. 837-838, 3 figs., May 1, 1909.

Gives notes on the occurrence and character of various ore deposits.

Keyes, Charles Rollin.

650. Lineaments of the desert.-Pop. Sci. Monthly, vol. 74, pp. 19-30, 8 figs., January, 1909. 
Keyes, Charles Rollin-Continued.

651. Geologic processes and geographic products of the arid region.-Abstract: Geol. Soc. America, Bull., vol. 19, pp. 570-575, 4 pls., 1 fig., 1909.

652. Erosional origin of the Great Basin ranges.-Jour. Geology, vol. 17, no. 1, pp. 31-37, 1 fig., 1909.

653. Ozark lead and zinc deposits, their genesis, localization, and migration.Am. Inst. Min. Eng., Bull., no. 26, pp. 119-166, 18 figs., February, 1909.

654. Garnet contact deposits of copper and the depths at which they are formed.Econ. Geology, vol. 4, no. 4, pp. 365-372, 3 figs., 1909. Min. World, vol. 31, pp. 465-466, 3 figs., August 28, 1909.

655. Base-level of eolian erosion.-Jour. Geology, vol. 17, no. 7, pp. 659-663, 1 fig., 1909.

656. Borax deposits of the United States.-Am. Inst. Min. Eng., Bull., no. 34, pp. 867-903, 20 figs., October, 1909.

The paper is devoted chiefly to a description of the occurrence and origin of the deposits of borax in the desert regions of southeastern California. The geologic structure of the region is discussed.

657. The genesis of the Ozark lead-zinc deposits.-Min. World, vol. 30, pp. 431433, 481-485, 543-546, 18 figs., March, 1909.

658. Locus of vadose ore deposition.-Eng. and Min. Jour., vol. 87, pp. 857-858, April 24, 1909.

Discusses the occurrence of the lead and zinc deposits of the Ozark region of Missouri.

659. Migrations of the Joplin zinc belt.-Eng. and Min. Jour., vol. 87, p. 1049, 2 figs., May 22, 1909.

660. American borax deposits.-Eng. and Min. Jour., vol. 88, pp. 826-827, 1 fig., October 23, 1909.

Describes the occurrence of borate minerals in the Tertiary clays of southern California and the lithology of the Tertiary terranes.

661. Differential effects of eolian erosion upon rock-belts of varying induration.Abstract: Science, new ser., vol. 29, pp. 752-753, May 7, 1909.

662. Locus of maximum lateral deflation in desert ranges.-Abstract: Science, new ser., vol. 29, p. 753, May 7, 1909.

663. Significance of thrust-planes in the Great Basin ranges.-Abstract: Science, new ser., vol. 29, p. 982, June 18, 1909.

664. Orotaxial correlation of geologic terranes and diastrophism.-Abstract: Science, new ser., vol. 29, p. 982, June 18, 1909.

665. Carbonic column of the Rio Grande region.-Abstract: Science, new ser., vol. 29, p. 982, June 18, 1909.

Genesis of the Lake Valley, New Mexico, silver deposits.-Am. Inst. Min. Eng., Trans., vol. 39, pp. 139-169, 8 figs., 1909. See no. 586 of the bibliography for 1908, U. S. Geol. Survey, Bull. 409, p. 50.

Kindle, Edward $M$.

666. The Devonian fauna of the Ouray limestone.-U. S. Geol. Survey, Bull. 391, 60 pp., 10 pls., 1909.

Discusses the stratigraphic relations of the Ouray limestone of Colorado and New Mexico and the faunas contained therein and gives systematic descriptions and figures of the Devonian forms.

667. Notes on the Point Hope spit, Alaska.-Jour. Geology, vol. 17, no. 2, pp. 178-189, 2 figs., 1909.

668. Diatomaceous dust on the Bering Sea ice floes.-Am. Jour. Sci., 4th ser., vol. 28, pp. 175-179, 1 fig., August, 1909. 
Kindle, Edward M.-Continued.

669. The section at Cape Thompson, Alaska.-Am. Jour. Sci., 4th ser., vol. 28, pp. 520-528, December, 1909.

Describes the general geologic relations of the rocks in the vicinity of Cape Thompson, the occurrence and character of Carboniferous and Mesozoic strata. Includes lists of fossils identified and remarks upon their age by David White, G. H. Girty, and T. W. Stanton.

Description of the Watkins Glen-Catatonk district, New York.-See Williams, Tarr, and Kindle, no. 1255.

Kindle, E. M., and Barnett, V. H.

670. The stratigraphic and faunal relations of the Waldron fauna in southern Indiana.-Indiana, Dept. Geology and Nat. Res., 33d Ann. Rept., pp. 393-416, 1909.

Kirk, Morris P.

671. The Presidio silver mines, Shafter, Texas.-Eng. and Min. Jour., vol. 88, pp. 318-819, 3 figs., October 23, 1909.

Includes notes on the occurrence and nature of the ore.

Klautzsch, A.

672. Das kalifornische Erdbeben vom 18. April 1906.-Gesellsch. Erdkunde, Berlin, Zeitschr., 1909, no. 9, pp. 609-616, 1909.

Describes the San Francisco earthquake with particular reference to its cause in the geologic structure of California.

Knapp, G. N.

Description of the Philadelphia district.--See Bascom and others, no. 74.

Knight, Cyril W.

673. The Winnipeg meeting of the British Association for the Advancement of Science.-Canadian Min. Jour., vol. 30, pp. 644-648, 5 figs., November 1, 1909.

Includes abstracts of papers relating to the geology of North America.

674. [On the Lower Huronian ice age.]-Canadian Min. Jour., vol. 30, pp. 727-728, December 1, 1909.

Discusses the evidences for the glacial origin of the Lower Huronian conglomerate.

Grenville-Hastings unconformity.-See Miller and Knight, no. 866.

Knirk, Carl F.

675. Natural gas in the glacial drift of Champaign County.-Illinois State Geol. Survey, Bull. no. 14, pp. 272-275, 1 fig., 1909.

Knopf, Adolph.

676. Some features of the Alaskan tin deposits.-Econ. Geology, vol. 4, no. 3, pp. 214-223, 1909. Min. World, vol. 30, pp. 969-971, May 22, 1909.

Describes the occurrence, character, geology, and mineralogic associations of tin deposits in Seward Peninsula.

677. Copper-bearing amygdaloids of the White River region, Alaska.-Science, new ser., vol. 29, p. 949, June 11, 1909.

Mineral resources of the Nabesna-White River district, Alaska.-See Moffit and Knopf, no. 874.

Knowlton, Frank Hall.

678. The stratigraphic relations and paleontology of the "Hell Creek beds," "Ceratops beds," and equivalents, and their reference to the Fort Union formation.-Washington Acad. Sci., Proc., vol. 11, no. 3, pp. 179-238, 1909.

Concludes that the beds named should be referred to the Fort Union formation and are Eocene in age. 
Koeberlin, F. R.

679. The Brewster iron-bearing district of New York.-Econ. Geology, vol. 4, no. 8, pp. 713-754, 7 figs., 1909.

Kolderup, C. F.

680. Jordskjælvet i San Francisco.-Naturen, Bergen, Aarg. 30, no. 11, pp. 333-340, 2 figs., November, 1906.

An account of the San Francisco earthquake extracted from the report of the California State Earthquake Commission report.

Kraus, E. H., and Cook, C. W.

681. Iodyrite from Tonopah, Nevada, and Broken Hill, New South Wales.-Am. Jour. Sci., 4th ser., vol. 27, pp. 210-222, 10 figs., March, 1909. Zeitschr. Krystal. und Mineral., Bd. 46, Heft 5, pp. 417-426, 1909.

Describes the occurrence, composition, and crystallography.

Kümmel, Henry B.

682. Geological section of New Jersey.-Jour. Geology, vol. 17, no. 4, pp. 351-379, 1909.

683. Administrative report for the year ending October 31, 1908.-New Jersey Geol. Survey, Ann. Rept. State Geologist for 1908, pp. 3-15, 1909.

684. Further notes on the changes at Manasquan Inlet.-New Jersey Geol. Survey, Ann. Rept. State Geologist for 1908, pp. 17-21, 1 pl, 1909.

685. Notes on the mineral industry, with mineral statistics.-New Jersey Geol. Survey, Ann. Rept. State Geologist for 1908, pp. 125-146, 1909:

686. Copper mining in New Jersey.-Eng. and Min. Jour., vol. 87, p. 808, April 17, 1909.

Includes notes on the occurrence of the ores.

687. Soil surveys as related to geology.-New Jersey State Board Agric., 36th Ann. Rept., pp. 162-169, 1909.

Description of the Philadelphia district.-See Bascom and others, no. 74 .

Description of the Trenton quadrangle, New Jersey-Pennsylvania.-See Bascom and others, no. 75 .

Kunz, George F., and Washington, Henry S.

Diamonds in Arkansas.-Am. Inst. Min. Eng., Trans., vol. 39, pp. 169-176, 1909. See no. 616 of the bibliography for 1908, U. S. Geol. Survey, Bull. 409, p. 52 .

Laflamme, C.

688. Les monțagnes Notre-Dame et les Shickshocks.-Soc. géog. Québec, Bull., pp. 3-13, January, 1909.

Gives a general account of the physiography, geology, and mineral deposits of the Notre Dame and Shickshock Mountains, Quebec.

689. Les Laurentides.--Soc. géog. Québec, Bull., pp. 62-70; January, 1909. Gives a general account of the physiography and geology of the Laurentian Highlands.

Ia Forge, Laurence.

- 690. Correlation of the rocks of the Boston region.-Abstract: Science, new ser., vol. 29; pp. 945-946, June 11, 1909.

Notes on the crystallography of leadhillite.-See Palache and La Forge, no. 930.

Laguerenne, Teodoro L.

691. Descripcion de la zona minera en el mineral de Pregones, municipalidad de Tetipac, Distrito de Alarcon, en el Estado de Guerrero.-Soc. Geol. Mexicana, Bol., t. 5, pp. 25-35, 1 pl., 1909.

Describes the general geology of the mining district of Pregones, State of Guerrero, Mexico, the vein system, the deposits of lead and silver, and the mines. 
Lahee, Fred. H.

692. Theory and hypothesis in geology.-Science, new ser., vol. 30 , pp. 56́2-563, October 22, 1909.

Lakes, Arthur.

693. Cause of fine gold in San Juan River, Utah.-Min. Reporter, vol. 56, pp. 308-309, October 3, 1907.

694. Some interesting experiences with ore-bearing veins; the occurrence and peculiarities of lenticular plication veins in the State of Idaho.-Min. Science, vol. 57, p. 122, 3 figs., January 30, 1908.

695. The general geology of Summit County, Colorado, with special reference to Breckenridge and vicinity.-Min. Science, vol. 57, pp. 243-244, 289291, 6 figs., March 5 and 12, 1908.

696. Prospecting in the oil fields of eastern and western Colorado.-Min. Science, vol. 57, pp. 404-406, 422-424, 2 figs. (maps), April 23 and 30, 1908.

697. Evolution of knowledge of veins and ore deposits.-Min. Science, vol. 58, pp. 5-6, 3 figs., July 2, 1908.

698. Organic matter in mines, veins, and ore deposits.-Min. Science, vol. 58, p. 170, August 27, 1908.

699. Study of geological faults in seashore cliffs.-Min. Science, vol. 58, pp. 525527, 6 figs., December 31, 1908.

700. Why are mining camps centers of mineralization?-Min. Science, vol. 59 , pp. 65-66, 85-87, 104-105, 124-126, 145-148, 168, 184-186, 204-206, 224-225, 14 figs., 1909.

701. Intersection, faulting, and movements in veins.-Min. Science, vol. 59, pp. 247-248, 1 fig., April 1, 1909.

702. The building stones of the Rocky Mountains.-Min. Science, vol. 59,.pp. 344345, 2 figs., May 6, 1909.

703. The origin, character, and distribution of gold in alluvial deposits.-Min. Science, vol. 59, pp. 471-472, 490-491, June 17 and 25, 1909; vol. 60, pp. 8-9, July 1, 1909.

704. The origin of nuggets and metallic masses in veins.-Min. Science, vol. 60 , pp. 27-28, 2 figs., July 8, 1909.

705. The origin of oil.-Min. Science, vol. 60, pp. 124-125, 1 fig., August 12, 1909.

706. Natural gas in Colorado and Wyoming.-Min. Science, vol. 60, p. 225, 1 fig., September 9, 1909.

707. The Hahns Peak mining region, Routt County, Colorado.-Min. Science, vol. 60, pp. 292-296, 6 figs., September 30, 1909.

708. Hydrocarbons in the United States: Asphalt, gilsonite, and other hydrocarbons, their distribution, modes of occurrence, and methods used in mining them.-Min. Science, vol. 60, pp. 340-342, October 14, 1909.

709. The volcanic or organic origin of oil.-Min. Science, vol. 60, pp. 367-368, October 21, 1909.

710. The Wyoming asbestos deposits and.mills.-Min. Science, vol. 60, pp. 388391, 1 fig., October 28, 1909.

711. Precious stones, geological distribution and mode of occurrence in North America.-Min. Science, vol. 60, pp. 414-416, 3 figs., November 4, 1909.

712. Determination of depths to horizontal coal seams.-Min. Science, vol. 60, pp. 508-510, 2 figs., December 2, 1909.

713. The marine organic origin of petroleum.-Min. Sci., vol. 60, pp. 560-562, December 16, 1909.

714. The many varied occurrences of ore in veins.-Min. World, vol. 30 , pp. 351-: 352, 1 fig., February 20, 1909.

715. Ores in volcanic craters and fumarole orifices.-Min. World, vol. $30, \mathrm{pp} .425-$ 427, 1 fig., March 6, 1909. 
Lakes, Arthur-Continued.

716. Modern ancient volcanoes and ore deposits.-Min. World, vol. 30, pp. 583584, 1 fig., March 27, 1909.

717. Occurrence of ore deposits in mineral belts.-Min. World, vol. 30, pp. 669671, 2 figs., April 10, 1909.

718. The ore occurrence and origin of cave mines.-Min. World, vol. $30, \mathrm{pp} .727-$ 729, 4 figs., April 17, 1909.

719. Peculiar crystalline forms of minerals and metals.-Min. World, vol. 30, pp. 831-832, 4 figs., May 1, 1909.

720. Geology of the mineral resources of Colorado.-Min. World, vol. 30, pp. 977978, 1 fig., May 22, 1909.

721. Tin, its history, uses, and occurrence.-Min. World, vol. 30, pp. 1170-1171, 1 fig., June 19, 1909.

722. Interesting little black dikes.-Min. World, vol. 31, p. 218, July 24, 1909.

723. The depth and continuity of fissure veins.-Min. World, vol. 31, pp. 363-364, 1 fig., August 14, 1909.

Lambe, Lawrence $M$.

724. The fish fauna of the Albert shales of New Brunswick.-Am. Jour. Sc̣i., 4th ser., vol. 28, pp. 165-174, 8 figs., August, 1909.

Includes a description of Elonichthys ellsi $\mathrm{n}$. sp.

725. [Report on] vetebrate paleontology.-Canada Geol. Survey, Summ. Rept., 1908, pp. 176-178, 1909.

Lane, Alfred C.

726. Discussion of paper by H. M. Howe: Piping and Segregation in Steel Ingots.Am. Inst. Min. Eng., Trans., vol. 38, pp. 931-934, 1908.

Discusses the application to magmas of facts and conclusions in the paper cited.

727. Tenth annual report of the state geologist [of Michigan] to the Board of Geological Survey for the year 1908.-Michigan Miner, vol. 11, no. 2, pp. 9-17, 1 fig., January, 1909.

728. Mine waters and their field assay.-Geol. Soc. America, Bull., vol. 19, pp. 501-512, 1 fig., 1909.

729. The decomposition of a boulder in the Calumet and Hecla conglomerate, and its bearing on the distribution of copper in the Lake Superior copper lodes as indicating the trend and characters of the waters forming the chute.-Econ. Geology, vol. 4, no. 2, pp. 158-173, 1 fig., 1909.

730. Salt water in the Lake mines.-Michigan Miner, vol. 11, no. 4, pp. 24-26, March, 1909.

731. Geclogy of the Porcupine Mountains, Michigan.-Min. World, vol. 30, pp. 1115-1117, 3 figs., June 12, 1909.

732. Michigan iron mines and their mine waters.-Min. World, vol. 31, pp. 413416, August 21, 1909.

Gives a general account of the geology of the iron regions of Michigan and discusses the origin of the iron ores and analyses of waters from the mines.

Notes on the Marshall and Grand Rapids formations.-See Cooper, no. 285.

Lane, A. C., and others.

733. Nomenclature and subdivision of the upper Siluric strata of Michigan, Ohio, and western New York.-Geol. Soc. America, Bull., vol. 19, pp. 553$556,1909$.

Lane, Louis.

734. Santa Eulalia Camp [Chihuahua, Mexico].-Min. and Sci. Press, vol. 99, p. 16, July 3, 1909.

Includes notes on the local geology. 


\section{Laney, Francis Baker.}

735. The Gold Hill copper district.-North Carolina Geol. and Econ. Survey, Econ. Paper no. 15, pp. 20-54, 6 pls., 1908.

Gives a general description of the rocks and structure of the district, and of the occurrence, character, and relations of the gold-copper ores.

Laney, Francis Baker, and Wood, Katharine Hill.

736. Bibliography of North Carolina geology, mineralogy, and geography, with a list of maps.-North Carolina Geol. and Econ. Survey, Bull. no. 18, 428 pp., 1909.

Langford, D. B.

737. A tour with the Canadian Mining Institute through the chief mining districts of Canada.-Inst. Min. Eng., Trans., vol. 37, pt. 5, pp. 607-622, 2 figs, 1909.

Includes various notes upon the economic geology of Nova Scotia, New Brunswick Quebec, Ontario, Alberta, and British Columbia.

Larsen, Esper S.

Quartz as a geologic thermometer.-See Wright and Larsen, no. 1292.

Larsh, W. S.

738. Mining at Hamilton, Nevada. Geology of the White Pine district.-Mines and Minerals, vol. 29, pp. 521-523, 1 fig., June, 1909.

Describes the local geology and the occurrence and relations of silver, copper, and lead deposits.

Lawson, Andrew C.

739. Slickensides.-Min. and Sci. Press, vol. 98, p. 247, February 13, 1909.

740. Review of A handbook for field geologists, by C. W. Hayes.-Econ. Geology, vol. 4, no. 7, pp. 667-671, 1909.

Lawton, N. Oliver.

741. Makushin sulphur deposits, Unalaska.-Min. and Sci. Press, vol. 98, pp. 259-260, 2 figs., February 13, 1909.

Describes the location, extent, and character of sulphur deposits on Unalaska Island.

Leach, W. W.

742. The Bulkley Valley and vicinity [British Columbia].-Canada, Geol. Survey, Summ. Rept., 1908, pp. 41-45, 1909. Canadian Min. Jour., vol. 30, pp. 372-374, June 15, 1909. British Columbia, Ann. Rept. Minister of Mines for 1908, pp. 168-172, 1909.

Includes an accouut of the geology and occurrence of coal and other mineral resources.

\section{Lee, Willis Thomas.}

743. The Grand Mesa coal field, Colorado.-U. S. Geol. Survey, Bull. 341, pp. 316-334, 1 pl. (map),.1909.

Describes the general surface features, stratigraphy and structure of the field, the geographic distribution and character of the coal beds, and the composition of the coals.

744. Unconformity in the so-called Laramie of the Raton coal field, New Mexico.-

- Geol. Soc. America, Bull., vol. 20, pp. 357-368, 3 pls., 1 fig., November, 1909 .

Describes the rock formations of the region and presents and discusses the evidences of an unconformity previously unknown, the extent of the erosion interval, and the correlations of the formations between which the unconformity exists.

745. Stratigraphy of the Manzano group of the Rio Grande valley, New Mexico.U. S. Geol. Survey, Bull. 389, pp. 5-40, 5 pls., 9 figs., 1909. 
Lee, Willis Thomas-Continued.

746. On an occurrence of coal changed to coke and graphite in the Raton, New Mexico, coal field.-Abstract: Science, new ser., vol. 29, pp. 198-199, January 29, 1909.

747. The correlation of sections lithologically similar.-Abstract: Science, new ser., vol. 29, p. 239, February 5, 1909.

Presents evidence bearing upon the correlation of coal-bearing rocks in the Grand Mesa coal field of Colorado and the Raton coal field of New Mexico.

748. Uncomformity separating the coal-bearing rocks in the Raton field, New Mexico.-Abstract: Science, new ser., vol. 29, p. 624, April 16, 1909.

Lee, Willis T., and Nickles, John M.

749. Classified list of papers dealing with coal, coke, lignite, and peat contained in publications of U. S. Geological Survey, except those on Alaska.U. S. Geol. Survey, Bull. 341, pp. 419-436, 1909. U. S. Geol. Survey, Mineral Resources, 1908, pt. 2, pp. 197-211, 1909.

Lees, James H.

750. History of coal mining in Iowa.-Iowa Geol. Survey, vol. 19, pp. 523-588, 1909.

751. General section of the Des Moines stage of Iowa.-Iowa Geol. Survey, vol. 19, pp. 598-604, $190 \hat{9}$.

752. Bibliography of Iowa coals.-Iowa Geol. Survey, vol. 19, pp. 659-687, 1909.

753. Bibliography of Iowa peat.-Iowa Geol. Survey, vol. 19, pp. 731-733, 1909.

Lees, James H., and Hixson, A. W.

754. Analyses of Iowa coals.-Iowa Geol. Survey, vol. 19, pp. 476-519, 1909.

Leighton, Henry.

755. One hundred years of New York state geological maps, 1809-1909.-New York State Mus., Bull. 133, pp. 115-155, 1 pl., 1909.

Reviews the progress in geological mapping and gives a chronologic list of geologic maps of the State of New York.

Leith, Charles Kenneth.

Pre-Cambrian geology of North America.-See Van Hise and Leith, no. 1178.

Lenher, Victor.

756. Some observations on the tellurides.-Econ. Geology, vol. 4, no. 6, pp. 544564, 1909.

Leonard, A. G.

757. Administrative report [of the Geological Survey of North Dakota for the years 1907 and 1908].-North Dakota Geol. Survey, 5th Bienn. Rept., pp. 17-26, 1908.

758. Geology of southwestern North Dakota, with special reference to the coal..North Dakota Geol. Survey, 5th Bienn. Rept., pp. 27-114, 19 pls., 1908.

759. The geological history of North Dakota.-North Dakota Geol. Survey, 5th Bienn. Rept., pp. 227-243, 1908.

Leonard, A. G., and others.

760. Fifth Biennial Report State Geol. Survey of North Dakota, Bismärck, 1908. $278 \mathrm{pp} ., 30 \mathrm{pls}$.

Leonard, A. G., and Smith, Carl D.

761. The Sentinel Butte lignite field, North Dakota and Montana.-U. S. Geol. Survey, Bull. 341, pp. 15-35, 1 pl., 1 fig., 1909.

Describes the stratigraphy and structure of the field; the occurrence, character, and relations of the lignite beds; the character and uses of the lignite; and the mining operations. 
LeRoy, Osmond E.

762. Phoenix camp and Slocan district [British Columbia].-Canada, Geol. Survey, Summ. Rept., 1908, pp. 65-68, 1909.

Describes the general geology and the occurrence, character, and relations of the goldsilver-copper ores, and the mining developments.

Leverett, Frank.

763. Weathering and erosion as time measures.-Am. Jour. Sci., 4th ser., vol. 27, pp. 349-368, 7 figs., May, 1909.

Discusses the erosion and weathering to which the drift sheets have been subjected as criteria for distinguishing them and determining their chronology and correlation with the drift sheets of Europe.

Lẽvison, Wallace Goold.

764. On the origin and sequences of the minerals of the Newark (Triassic) igneous rocks of New Jersey.-New York Acad. Sci., Annals, vol. 19, pt. 1, pp. 121-134, 3 pls., 1909.

Lewington, Guy A. R.

765. White River copper properties [Alaska].-Min. and Sci. Press, vol. 99, pp. 755-756, 1 fig., December 4, 1909.

Lewis, J. Volney.

766. Building stones of New Jersey.-New Jersey Geol. Survey, Ann. Rept. State Geologist for 1908, pp. 53-124, 20 pls., 1909.

767. Prospecting for ores of the Goldfield type.-Eng. and Min. Jour., vol. 87, pp. 1121-1122, June 5, 1909.

Describes the characters and occurrence of alunite.

Lincoln, Francis Church.

768. The Big Bonanza copper mine, Latouche Island, Alaska.-Econ. Geology, vol. 4, no. 3, pp. 201-213, 5 figs., 1909.

Describes the general geology, the character of the ore deposit, and the paragenesis of the minerals.

Lindgren, Waldemar.

769. The localization of values in ore bodies and the occurrence of shoots in metalliferous deposits.-Econ. Geology, vol. 4, no. 1, pp. 56-61, 1909.

770. Investigations relating to deposits of metalliferous ores.-U. S. Geol. Survey, Bull. 380, pp. 16-20, 1909.

Gives a list of publications relating to deposits of metalliferous ores in the United States, issued by the United States Geological Survey in 1908, and outlines briefly the progress of investigation and the preparation of reports.

771. The Tres Hermanas mining district, New Mexico.-U. S. Geol. Survey, Bull. 380, pp. 123-128, 1909.

Describes the general features and geology, and the occurrence, character, and relations of the zinc and lead ores.

772. Resources of the United States in gold, silver, copper, lead, and zinc.-U.S. Geol. Survey, Bull. 394, pp. 114-156; 6 pls., 1909. Rept. Nat. Conservation Comm. (60th Cong., 2d sess., Sen. Doc. no. 676), vol. 3, pp. 521-557, 6 pls., 1909.

773. Metallogenetic epochs.-Econ. Geology, vol. 4, no. 5, pp. 409-420, 1909. Canadian Min. Inst., Jour., vol. 12, pp. 102-113, 1910. Canadian Min. Jour., vol. 30, pp. 430-434, July 15, 1909. Min. World, vol. 31, pp. 1111-1113, December 4, 1909.

Summarizes the facts known regarding the distribution of ore deposits in the various geologic ages in the continent of North America. 
Lindgren, Waldemar-Continued.

774. [The discovery of a selenium mineral in the gold-quartz ores of the Republic district, Washington.]-Abstract: Science, new ser., vol. 30, p. 972, December 31, 1909.

Mineral resources of the United States, 1908: Gold and silver.-See no. 1170.

Contributions to economic geology, 1908. Part I. Metals and nonmetals, except fuels.-See no. 1169.

Linsley, Earle G.

A syllabus for the study of the physiographic provinces of California.-See Holway and Linsley, no. 589.

Linton, Robert.

775. East Texas iron.-Los Angeles Min. Review, vol. 27, no. 14, p. 12, December $25,1909$.

Loftus, J. P.

776. Round Mountain [Nevada], its mines and its history.-Am. Min. Cong., 12th Ann. Sess., Rept. of Proc., pp. 445-448, 1909.

Includes notes on the local geology and the occurrence of the gold ores.

Logan, William E.

777. Section of the Nova Scotia coal measures, as developed at the Joggins, on the Bay of Fundy, in descending order, from the neighborhood of the West Ragged Reef to Minudie, reduced to vertical thickness (reprinted from Report of Progress of the Geological Survey of Canada for 1843, pp. 92156).-Nova Scotian Inst. Sci., Proc. and Trans., vol. 11, pt. 3, pp. 419$499,1908$.

Logan, William $\mathrm{N}$.

778. The pottery clays of Mississippi.-Mississippi State Geol. Survey, Bull. no. 6, 228 pp., 45 pls. and figs., 1909.

Loomis, F. B.

779. Turtles from the upper Harrison beds [Nebraska].-Am. Jour. Sci., 4th ser., vol. 28, pp. 17-26, 9 figs., July, 1909.

Describes Testudo arenivaga, Hay, Testudo brevisterna n. sp., and Testudo undabuna n. sp.

780. Camels of the lower Miocene.-Abstract: Science, new ser., vol. 29, p. 196, January 29, 1909.

Louderback, George Davis.

781. Benitoite, its paragenesis and mode of occurrence, with chemical analyses by Walter C. Blasdale.-California Univ., Dept. Geol., Bull., vol. 5, no. 23, pp. 331-380, 13 pls.

Describes the general geologic surroundings and mode of occurrence in San Benito County, Cal., the conditions under which the mineral was formed, the general relations of the minerals in the veins, and the crystallography and other features of benitoite, neptunite, natrolite, and other associated minerals.

782. Chief features of the stratigraphy and structure of Mount Diablo, California.Abstract: Geol. Soc. America, Bull., vol. 19, pp. 537-538, 1909.

Loughlin, G. F.

783. Ore deposition at Aspen, Colorado.-Econ. Geology, vol. 4, no. 7, pp. 658-660, 1909.

Ludlow, Edwin.

784. The coal industry in Mexico.--Eng. and Min. Jour., vol. 88, pp. 661-664, 1 fig., October 2, 1909.

Includes notes on the occurrence and composition of coals in the State of Coahuila, Mexico. 
Lull, Richard Swan.

785. Dinosaur societies.-Abstract: Science, new ser., vol. 29, p. 194, January 29, 1909.

The evolution of the elephant.-Smithsonian Inst., Ann. Rept., 1908, pp. 641-675, 2 pls., 29 figs., 1909.

Reprinted, after author's revision, from the American Journal of Science, vol. 25, March, 1908.

Luther, D. Dana.

786. Geology of the Geneva-Ovid quadrangles, New York.-New York State Mus., Mus. Bull. 128, 41 pp., 2 pls. (geologic map and sections) in pocket, 1909.

Describes the occurrence, character, relations, and fossil content of Silurian and Devonian formations.

Lyman, Benjamin Smith.

787. Need of instrumental surveying in practical geology.-Am. Inst. Min. Eng., Bull., no. 32, pp. 667-674, August, 1909.

Lyon, Edward West.

788. The progress of gold mining in North Carolina.-Eng. and Min. Jour., vol. 87, pp. 293-297, 4 figs., February 6, 1909.

Includes notes on the geologic occurrence and mineralogic character of the ore bodies.

MacAlister, D. A.

The geology of ore deposits.-See Thomas and MaicAlister, no. 1144.'

McCallie, S. W.

789. In memoriam, William Smith Yeates, 1856-1908.-Georgia, Geol. Survey, Bull. no. 19, pp. 7-8, 1909.

790. The Pickens County meteorite.-Science, new ser., vol. 30, pp. 772-773, November 26, 1909.

Gives a description, with analysis, of a stone-iron meteorite from Pickens County, Ga.

McCaskey, H. D.

Mineral resources of the United States, 1908: Gold and silver; quicksilver.See no. 1170.

MaConnell, R. G.

791. The Whitehorse copper belt, Yukon Territory.-Canada, Geol. Survey, 63 pp., 2 pls., 2 figs., 8 maps, 1909. Abstract: Canadian Min. Jour., vol. 30, pp. 709-714, 747-752, 3 figs., 1909.

A report on the geology and unineral resources of the Whitehorse district.

792. Northwestern portion of Texada Island.-Canada, Geol. Survey, Summ. Rept. 1908, pp. 46-50, 1909. British Columbia, Ann. Rept. Minister of Mines, for 1908, pp. 150-154, 1 pl. (map), 1909.

Describes the general geology and the mineral deposits, producing chiefly copper, gold, and iron.

McCormick, Clinton P.

793. Mining on Prince William Sound, Alaska.-Min. World, vol. 31, pp. 11991202, 6 figs., December 18, 1909.

Includes notes on the occurrence and character of copper ores.

McCourt, W. E.

794. Diamonds in Arkansas.-Abstract: Science, new ser., vol. 30, p. 127, July 23, 1909.

McDermott, Walter.

785. The Silver Islet vein, Lake Superior.-Canadian Min. Jour., vol. 30, pp. 135138, March 1, 1909.

Describes the occurrence and geologic relations of silver ore mined on Silver Islet, Lake Superior. 
McDermott, Walter-Continued.

796. The Silver Islet vein, Lake Superior--Inst. Min. and Metal., London, Trans., vol. 18, pp. 220-231, 1909.

Reprinted from the Eng. and Min. Jour., vol. 23, pp. 54-55, January 27, 1877.

Describes the character and occurrence of the ore deposits.

MacDonald, Bernard.

797. Discussion of paper by C. R. Keyes, Genesis of the Lake Valley, New Mexico, silver deposits.-Am. Inst. Min. Eng., Bull., no. 26, pp. 211-216, February, 1909.

MacDonald, Donald Francis.

798. Notes on the Bohemia mining district, Oregon.-U. S. Geol. Survey, Bull. 380 , pp. 80-84, 1909.

Gives notes upon the geology, the character, relations, and mineralization of the veins, and the gold mines.

799. Notes on the economic geology of northern Idaho and north western Montana.U. S. Geol. Survey, Bull. 384, pp. 92-108, 1909.

Macdougal, D. T.

800. Origination of self-generating matter and the influence of aridity upon its evolutionary development.-Jour. Geology, vol. 17; no. 7, pp. 603-622, 5 figs., 1909.

McEvoy, James.

801. Abstract of report on the Kananaskis coal lands [Alberta].-Canadian Min. Jour., vol. 30, pp. 141-143, 1 fig., March 1, 1909.

802. Abstract of report on Bighiorn and Brazeau coal lands [Alberta].-Canadian Min. Jour., vol. 30, p. 143, March 1, 1909.

MacFarland, Ira.

803. Development of petroleum in Nevada.-Am. Min. Cong., 12th Ann. Session, Rept. of Proc., pp. 418-422, 1909.

MacFarlane, James.

804. The Ohio Copper Company, Bingham, Utah.-Min. World, vol. 30, pp. 345348, 4.figs., February 20, 1909.

Includes notes on the local geology and the occurrence of the copper ores.

MacFarren, H: W.

805. The story of Bingham Canyon [Utah].-Min. and Sci. Press, vol. 99, pp. 129130, 1 fig., July 24, 1909.

Includes notes on the geology and occurrence of the ores.

806. Ozokerite in Utah.-Min. and Sci. Press, vol. 99, pp. 789-790, 1 fig., December 11, 1909.

McInnes, William.

807. Explorations on the Churchill River and South Indian Lake.-Canada, Geol. Survey, Summ. Rept., 1908, pp. 87-92, 1909.

Includes notes on the geology of the region examined.

Maddren, A. G.

808. Gold placers of the Ruby Creek district, Alaska.-U. S. Geol. Survey, Bull. 379, pp. 229-233, 1 pl. (map), 1909.

809. Placers of the Gold Hill district, Alaska.-U. S. Geol. Survey; Bull. 379, pp. 234-237, 1909.

810. Gold placers of the Innoko district, Alaska.-U. S. Geol. Survey, Bull. 379, pp. 238-266, 1909.

Mineral resources of the Kotsina-Chitina region, Alaska.-See Moffit and Maddren, no. 875 . 


\section{Maine State Survey Commission.}

811. Fifth biennial report, 1907-1908. Waterville, 1909. $11 \mathrm{pp.}$

An administrative report upon the progress of topographic, geologic, and hydrographic work.

Malloch, G.

812. The Big Horn coal basin [Alberta].-Canada, Geol. Survey, Summ. Rept., 1908, pp. 70-76, 1909.

Describes the general geology and occurrence and character of the coal.

Mansfield, George Rogers.

813. Glaciation in the Crazy Mountains of Montana.-Geol. Soc. America, Bull., vol. 19, pp. 558-567, 3 pls., I fig., 1909.

Marbut, Curtis F.

814. The college unit in physical geography.-Jour. Geog., vol. 7, no. 9, pp. 193208, May, 1909.

Marriott, Hugh E.

A visit to the mineral districts of Canada.-See Frecheville and Marriott, no. 426.

Marrs, G. O.

815. The genesis of various types of ore deposits.-Min. Science, vol. 59, pp. 49-51, 10 figs., January 21, 1909.

Martin, Al. H.

816. San Francisco district, Arizona.-Min. World, vol. 31, p. 368, August 14, 1909, Includes notes on the occurrence of gold ores.

817. The Alleghany mining district, California.-Min. World, vol. 31, pp. 589-592, 8 figs., September 18, 1909.

Includes notes on the local geology, and the occurrence and character of the gold deposits.

818. Gold mining at Grass Valley, California.-Min. World, vol. 31, pp. 823-825, 7 figs., October 23, 1909.

Includes notes on the local geology and the occurrence of gold ores.

Martin, George Curtis.

819. The Niobrara limestone of northern Colorado as a possible source of Portland cement material.-U. S. Geol. Survey, Bull. 380, pp. 314-326, 1 fig., 1909.

Describes the general geology of the foothills belt of northern Colorado, and the occurrence, character, and composition of limestones and shales.

Martin, Lawrence.

820. The relation of geology to topography.-Am. Geog. Soc., Bull., vol. 41, no. 3, pp. 138-142, 2 figs., March, 1909.

821. The Malaspina glacier region of Alaska.-Jour. Geology, vol. 17, no. 7, pp. 664-666, 1 fig., 1909.

822. Geography at the University of Wisconsin.-Jour. Geography, vol. 8, no. 2, pp. 39-42, October, 1909 .

Apparatus for topographic field work on models in the laboratory.-See Mead and Martin, no. 843 .

Marvin, C. F.

823. The Kingston earthquake.-Monthly Weather Review, vol. 35, no. 1, pp. 5-6, January, 1907.

Discusses the Kingston earthquake ac recorded in Washington, D. C.

Mather, Kirtley F.

824. The age of the Licking Narrows at Black Hand, Ohio.-Denison Univ., Sci. Lab., Bull., vol. 14, pp. 175-187, 5 figs., April, 1909.

Discusses the time and cause of drainage changes in this region. 
Mathews, Edward B., and Grasty, J. S.

825. The character and structural relations of the limestones of the Piedmont in Maryland and Virginia.-Abstract: Science, new ser., vol. 29, pp. 634635, April 16, 1909.

Mathez, Auguste.

826. Rye Valley gold mines, Oregon.-Min. and Sci. Press, vol. 99, p. 687, 1 fig., November 20, 1909.

Includes notes on the geologic relations of the ore deposits.

Matson, George Charlton.

827. Water resources of the Blue Grass region, Kentucky; with a chapter on the quality of the waters, by Chase Palmer.-U. S. Geol. Survey, WaterSupply Paper 233, 223 pp., 3 pls., 6 figs., 1909.

Includes an account of the stratigraphy of the region.

828. Notes on the clays of Florida.-U. S. Geol. Survey, Bull. 380, pp. 346-357, 1909 .

Describes the location, geologic horizon, and composition.

Matson, George Charlton, and Clapp, Frederick G.

829. A preliminary report on the geology of Florida with special reference to the stratigraphy.-Florida State Geol. Survey, 2d Ann. Rept., pp. 25-173, 8 pls., 2 figs., 1 map, 1909.

Matthes, François E.

830. The glacial character of Yosemite Valley.-Abstract: Science, new ser., vol. 29, p. 240, February 5, 1909; p. 754, May 7, 1909.

831. Débris tracks on the domes of the Yosemite region.-Abstract: Science, new ser., vol. 30, pp. 61-62, July 9, 1909.

Matthew, George F.

832. Geological cycles in the maritime provinces of Canada.-Roy. Soc. Canada, Proc. and Trans., 3d ser., vol. 2, sect. 4, pp. 121-143, 1908.

Outlines the geologic history of the region known as Acadia, citing the various evidences from which this has been determined and discussing the stratigraphic position and correlation of the geologic formations.

833. Phosphate deposits of South Carolina and New Brunswick.-New Brunswick Nat. Hist. Soc., Bull., no. 27 (vol. 6, pt. 2), pp. 121-126, 1909.

Matthew, William Diller.

834. The Carnivora and Insectivora of the Bridger basin, middle Eocene.-Am. Mus. Nat. Hist., Mem., vol. 9, pt. 6, pp. 289-567, 11 pls., 118 figs., 1909.

835. Observations upon the genus Ancodon.-Am. Mus. Nat. Hist., Bull., vol. 26, pp. 1-7, 1909 .

836. Faunal lists of the Tertiary Mammalia of the West. U. S. Geol. Survey, Bull. 361, pp. 91-120, 1909.

837. The oldest land reptiles of North America.-Arn. Mus. Jour., vol. 9, no. 4, pp. 91-95, 5 figs., April, 1909.

Gives some account of reptilian remains collected in the Permian of Texas.

838. Seventh annual meeting of the American Society of Vertebrate Paleontologists.-Science, new ser., vol. 29, pp. 194-198, January 29, 1909.

Gives an account $\mathrm{o}$ ! the meeting and abstracts of the papers read.

839. On a skull of Apternodus and skeleton of a new artiodactyl from the lower Oligocene of Wyoming.-Abstract: Science, new ser., vol. 29, p. 196, January 29, 1909.

Geological correlation through vertebrate paleontology by international cooperation. Correlation Bulletin, No. 1. Plan and scope.-See Osborn and Matthew, no. 918. 
Matthew, W. D., and Cook, Harold J.

840. A Pliocene fauna from western Nebraska.-Am. Mus. Nat. Hist., Bull., vol. 26, pp. 361-414, 27 figs., 1909. Abstract: Science, new ser., vol. 29, pp. 196-197, January 29, 1909.

Describes mammalian fossils from Sioux County, Nebr., and discusses their stratigraphic position.

Mauritz, B.

Ueber Kalomel.-See Goldschmidt and Mauritz, no. 459.

Maury, Carlotta J.

841. A new connecting link in the genesis of Fulgur.-Am. Jour. Sci., 4th ser., vol. 27, p. 335, 1 fig., April, 1909.

Describes Levifusus fulguriparens n. sp., from the Eocene at Montgomery, La.

Mead, Walter J.

842. Relation of density to the specific volume of ore. A graphic method for the determination of the specific volume of ore from its porosity and included moisture.-Min. Science, vol. 58, pp. 89-91, 1 fig., July 30, 1908.

Mead, W.. J., and Martin, Lawrence.

843. Apparatus for topographic field work on models in the laboratory.-Jour. Geography, vol. 7, no. 9, pp. 209-211, May, 1909.

Melsted, V. J.

The geology of northeastern North Dakota with special reference to cement materials.-See Barry and Melsted, no. 70.

Mendenhall, Walter Curran.

844. A phase of ground water problems in the West.-Econ. Geology, vol. 4, no. 1, pp. 35-45, 2 figs., 1909.

845. Some desert watering places in southeastern California and southwestern Nevada.-U. S. Geol. Survey, Water-Supply Paper 224, 98 pp., 4 pls., 1909.

Describes physical features $\varepsilon$ nd water supply of the region.

846. Ground waters of the Indio region, California, with a sketch of the Colorado Desert.-U. S. Geol. Survey, Water-Supply Paper ńo. 225, 56 pp.; 12 pls., 5 figs., 1909.

Describes the geography, the general geologic features, the character of the deposits, and the water resources.

847. Underground waters.-U. S. Geol. Survey, Water-Supply Paper 234, pp. 6877, 1909. Rept. Nat. Conservation Comm. (60th Cong., 2d sess., Sen. Doc. no. 676); vol. 2, pp. 86-94, 1909.

848. The Colorado Desert.-Nat. Geog. Mag., vol. 20, pp. 681-701, 16 figs., August, 1909.

849. A coal prospect on Willow Creek, Morrow County, Oregon.-U. S. Geol. Survey, Bull. 341, pp. 406-408, 1909.

Describes the occurrence, character, and value of the coal.

Merriam, John C.

850. The skull and dentition of an extinct cat closely related to Felis atrox Leidy.California, Univ., Dept. Geology, Bull., vol. 5, no. 20, pp. 291-304, 1 pl., 1909.

Describes Felis atrox var. bebbi from the Quaternary of Rancho La Brea, near Los Angeles, Cal.

851. The occurrence of strepsicerine antelopes in the Tertiary of northwestern Nevada.-California, Univ., Dept. Geol., Bull., vol. 5, no. 22, pp. 319330, December, 1909.

Describes Ilingoceros alexandræ n. gen. and n. sp., and Sphenophalos nevadanus n. gen. and n. sp., from late Tertiary beds near Thousand Creek in northern Humboldt County, Nev. 
Merrill, F. J. H.

852. Santa Eulalia mines, Chihuahua.-Min. and Sci. Press, vol. 98, pp. 37-39, 2 figs., January 2, 1909; vol. 99, p. 119, July 24, 1909.

Includes notes on the local geology and the occurrence of the silver ores.

853. Official definitions of mining terms.-Min. and Sci. Press, vol. 99, pp. 16-18, July 3, 1909.

Merrill, George P.

854. A heretofore undescribed stony meteorite from Thomson, McDuffie County, Georgia.-Smithsonian .Misc. Coll., vol. 52 (Quart. Issue, vol. 5, pt. 4), pp. 473-476, 2 pls., 1909.

855. Coon Butte or Meteor crater.-Abstract: Science, new ser., vol. 29, pp. 239240, February 5, 1909.

856. The composition of stony meteorites compared with that of terrestrial igneous rocks, and considered with reference to their efficacy in world-making.Am. Jour. Sci., 4th ser., vol. 27, pp. 469-474, June, 1909. Abstract: Science, new ser., vol. 29, p. 948, June 11, 1.909.

Merwin, H. E.

Alamosite, a new lead silicate from Mexico.-See Palache and Merwin, no. 931 .

On connellite and chalcophyllite from Bisbee, Arizona.-See Palache and. Merwin, no. 932.

\section{Mexico, Instituto Geologico.}

857. Catálogo de los temblores (macro y microseismos) sentidos en la República Mexicana, durante el primer semestre de 1909.-Mexico, Inst. Geol., Parerg., t. 3, no. 3, pp. 173-199, 1909.

A list of earthquakes and seismic shocks registered at the seismological station at Tacu- . baya, D. F., Mexico, during the first half of 1909.

Catálogo de los temblores (macroseismos) sentidos en la Republica Mexicana durante los años de 1904 a 1908.-See Aguilera, no. 7.

Millar, Austin Q.

858. The Arkansas diamond fields.-Min. and Sci. Press, vol. 99, p. 534, October $16,1909$.

Miller, Arthur M.

859. Evidence that the Appalachian and central coal fields were once connected across central Kentucky.-Abstract: Science, new ser., vol. 29, p. 624, April 16, 1909.

Describes the occurrence of coal measure conglomerate in central Kentucky.

Miller, Benjamin L.

860. Erosion intervals in the Tertiary of North Carolina and Virginia and their bearing upon the distribution of the formations.-Abstract: Science, new ser., vol. 29, p. 634, April 16, 1909.

Description of the Philadelphia district.-See Bascom and others, no. 74.

Description of the Trenton quadrangle, New Jersey-Pennsylvania.-See Bascom and others, no. 75 .

Miller, G. W.

861. The various mining districts of Colorado.-Min. Science, vol. 57, pp. $462-$ $464,507-510,532-534,549-551,10$ figs.; vol. 58, pp. 128-130, 207-208, 228-229, 246-247, 14 figs., 1909.

862. The De Lamar mines, Lincoln County, Nevada.-Min. Science, vol. 58, pp. 347-348, 3 figs., October 29, 1908.

Describes the character and occurrence of the gold deposits and the local geology. 
Miller, Loye Holmes.

863. Pavo californicus, a fossil peacock from the Quaternary asphalt beds of Rancho La Brea.-California, Univ., Dept. Geology, Bull., vol. 5, no. 19, pp. 285289, 1 pl., 1909.

864. Teratornis, a new avian genus from Rancho La Brea.-California, Univ., Dept. Geology, vol. 5, no. 21, pp. 305-317, 11 figs., 1909.

Describes Teratornis merriami n. gen. and n. sp., from the Quaternary asphait beds of Rancho La Brea in southern California.

Miller, Willet G.

865. The pre-Cambrian rocks of Canada.-Abstract: Canadian Min. Jour., vol. 30, p. 647, November 1, 1909.

Miller, Willet G., and Knight, Cyril W.

866. Grenville-Hastings unconformity.-Abstract: Geol. Soc. America, Bull., vol. 19, pp. 539-540, 1909.

Miller, William J. '

867. Geology of the Remsen quadrangle, including Trenton Falls and vicinity in Oneida and Herkimer counties.-New York State Mus., Mus. Bull. 126, 51 pp., 11 pls., 4 figs., 1 geol. map (in pocket), 1909.

Describes the general geologic features, the occurrence, character, and relations of preCambrian and Ordovician strata, the structural features, and the glacial geology.

868. Ice movement and erosion along the southwestern Adirondacks.-Am. Jour. Sci., 4th ser., vol. 27, pp. 289-298, 2 figs., April, 1909.

869. Pleistocene geology of the southwestern slope of the Adirondacks.-Abstract: Science, new ser., vol. 29, p. 627, April 16, 1909.

Millward, William.

870. Fossils from the glacial drift and from the Devonian and Mississippian near Meadville, Pennsylvania.-Carnegie Mus., Annals, vol. 5, pp. 480-487, 1909.

Gives lists of Paleozoic fossils found in limestone and chert pebbles of the Wisconsin drift and in bedded rocks of Carboniferous age and discusses the correlation of the formations of the latter.

\section{Mining and Scientific Press.}

871. Genesis of petroleum.-Min. and Sci. Press., vol. 99, p. 543, October 23, 1909.

872. Outcrop of ore bodies.-Min. and Sci. Press, vol. 99, p. 781, December 11, 1909.

Moffit, Fred H.

873. Mining in the Kotsina-Chitina, Chistochina, and Valdez Creek regions, Alaska.-U. S. Geol. Survey, Bull. 379, pp. 153-160, 2 figs., 1909.

Moffit, Fred H., and Knopf, Adolph.

874. Mineral resources of the Nabesna-White River district, Alaska.-U. S. Geol. Survey, Bull. 379, pp. 161-180, 1 pl., 1909.

Includes an account of the general geology.

Moffit, Fred H., and Maddren, A. G.

875. Mineral resources of the Kotsina-Chitina region, Alaska.-U. S. Geol. Survey, Bull. 374, 103 pp., 9 pls., 9 figis., 1909.

Describes the general geology, the occurrence and relations of Triassic and other rocks of undetermined or doubtful age, and the mineral resources, chiefly copper and placer gold. 
Moodie, Roy L.

876. Vertebrate paleontology: The Lysorophidæ; Stegocephala; The Cotylosauria; The oldest known reptile; The age of the Gaskohle; Bison occidentalis; Nectosaurus; Callibrachion.-Am. Naturalist, vol. 43, pp. 116-124, February, 1909.

Gives various notes upon the forms mentioned.

877. The Carboniferous quadrupeds. Those of Kansas, Ohio, Illinois, and Pennsylvania in their relation to the classification of the so-called Amphibia and Stegocephala.-Kansas Acad. Sci., Trans., vol. 22, pp. 239-247, 3 pls., 1909.

Discusses the occurrence, characters, and classification of Carboniferous Amphibia.

878. A contribution to a monograph of the extinct Amphibia of North America. New forms from the Carboniferous.-Jour. Geology, vol. 17, no. 1, pp. 38-82, 24 figs., 1909.

879. The Microsauria, ancestors of the Reptilia.-Geol. Mag., dec. 5, vol. 6, no. 5, pp. 216-220, 1 fig., May, 1909.

880. New or little-known forms of Carboniferous Amphibia in the American Museum of Natural History.-Am. Mus. Nat. Hist., Bull., vol. 26, pp. 347-357, 8 pls., 2 figs., 1909.

Moore, Elwood S.

881. Iron range north of Round Lake [Ontario].-Ontario, Bur. Mines, 18th Ann. Rept., vol. 18, pt. 1, pp. 154-162, 6 figs., 1909.

Gives an account of the geology of the region and the occurrence and character of iron deposits.

882. Bog iron on English River [Ontario].-Ontario, Bur. Mines, 18th Ann. Rept., vol. 18, pt. 1, pp. 180-195, 7 figs., 1909.

Gives an account of the geology and physiographic features of the region and of the distribution and character of bog iron deposits.

883. Geology of Onaman iron range area.-Ontario, Bur. Mines, 18th Ann: Rept., vol. 18, pt. 1, pp. 196-253, 35 figs., 1909.

Describes the geology of the area, the petrography of the rocks, and the occurrence, character, relations, and origin of the iron deposits.

884. The geology of the Lake Wendigokan region [Ontario].-Canadian Inst., Trans., vol. 8, pt. 3, pp. 341-361, 5 figs., 1 map, April, 1909.

Moore, Phil. H.

885. Leipsigate gold mining district, Nova Scotia.-Min. World, vol. 30, pp. 309-312, 9 figs., February 13, 1909.

Includes notes on the local geology and the occurrence and character of the gold ores.

Moore, Richard B.

Radioactivity of the thermal waters of Yellowstone National Park.-See Schlundt and Moore, no. 1033.

Morsack, Cajetan.

886. Feldspar mining in Ontario.-Eng. and Min. Jour., vol. 87, pp. 759-760, 1 fig., April 10, 1909.

Includes notes on the character and occurrence of the deposits.

Morse, William Clifford, and Foerste, August F.

887. The Waverly formations of east central Kentucky.-Jour. Geology, vol. 17, no. 2, pp. 164-177, 2 figs., 1909. 
Munn, Malcolm J.

888. Studies in the application of the anticlinal theory of oil and gas accumulation.-Econ. Geology, vol. 4, no. 2, pp. 141-157, 2 figs., 1909.

The discussion is based mainly upon structural and stratigraphic features of oil pools in the Sewickley quadrangle, Pennsylvania.

889. The anticlinal and hydraulic theories of oil and gas accumulation.--Econ. Geology, vol. 4, no. 6, pp. 509-529, 3 figs., 1909.

Nason, Frank L.

890. Some phenomena of the folding of rock strata.-Econ. Geology, vol. 4, no. 5, pp. 421-437, 4 figs., 1909.

Describes folds in the Sierra Madre Oriental Mountains in Nuevo Leon, Mexico, and explains their production and relations to ore-bearing fissures.

Nelson, Gaylord.

891. Tripoli deposits at Seneca, Missouri.-Min. World, vol. 31, p. 552, September 11, 1909.

Newland, David H.

892. The Clinton ores of New York State.-Am. Inst. Min. Eng., Bull., no. 27, pp. 265-283, 5 figs., March, 1909.

Describes the distribution of the Clinton formation, the general structure of the beds, the occurrence of the iron ores, and their origın.

893. A peculiar landslip in the Hudson River clays.-New York State Mus., Bull. 133, pp. 156-158, 2 pls., 1 fig., 1909.

894. The mining and quarry industry of New York State: Report of operations and production during 1908.-New York State Mus., Mus. Bull. 152, 99 pp., 1909.

Newsom, J. F.

Description of the Santa Cruz quadrangle, California.-See Branner and others, no. 138.

Nicholas, Francis C.

895. A method for demonstrating ore formations.-Min. World, vol. 30, pp. 349-350, 4 figs., February 20, 1909.

Nickles, John M.

896. Bibliography of North American Geology for 1906 and 1907, with subject index.-U. S. Geol. Survey, Bull. 372, 317 pp., 1909.

897. Bibliography of North American Geology for 1908, with subject index.-U.S. Geol. Survey, Bull. 409, 148 pp., 1909.

Classified list of papers dealing with coal, coke, lignite, and peat contained in publications of the U. S. Geological Survey, except.those on Alaska.See Lee and Nickles, no. 749.

Nicol, John M.

898. Placers of Waldo, South Oregon.-Min. and Sci. Press, vol. 99, pp. 122-1.24, 2 figs., July 24, 1909.

Includes notes on the local geology and the occurrence of placer gold.

Nicolas, Frank J.

899. General index of the reports of the Bureau of Mines of Ontario, Volumes I to XVI (1891-1907). Toronto, 1909. $466 \mathrm{pp}$.

Nordenskjöld, Otto.

800. On the geology and physical geography of east Greenland.-Meddelelser om Grönland, H. 28, pp. 151-284, 6 pls., 33 figs., 1909.

Describes the occurrence, character, and relations of Archean and post-Archean eruptive rocks and of Paleozoic, Triassic, Jurassic, and Tertiary deposits. 


\section{Northwest Mining Journal.}

901. Mineral resources of Washington.-Northwest Min. Jour., vol. 7, no. 5, pp. 54-123, illus., June, 1909.

Nylander, Olof 0 .

902. Fossil and living shells found in Little Mud Lake, Westmanland, Aroostook County, Maine.-Nautilus, vol. 22, pp. 105-106, February, 1909.

Nyström, Erik, and Anrep, S. A.

903. Investigation of the peat bogs and peat industry of Canada during the season 1908-9.-Canada, Dept. Mines, Mines Branch, Bull. no. 1, 25 pp., 5 pls., 1909.

Obalski, J.

904. Mining operations in the Province of Quebec for the year 1908.-Quebec, Dept. of Colonization, Mines and Fisheries, 85 pp., 19 pls., 1909.

Includes notes on the occurrence of various mineral deposits.

Odendall, Leonhard.

805. Die Kupferexzlagerstätten in Nordamerika. Inaugural-dissertation, Rheinischen Friedrich-Wilhelmş-Universität zu Bonn. Köln, 1909. 63 pp.

Describes the occurrence and characters of the principal copper deposits of the United States, Mexico, and Canada, and discusses the various types of deposits.

O'Harra, Cleophas C.

Description of the Belle Fourche quadrangle, South Dakota.-See Darton and O'Harra, no. 312 .

\section{Ohio Geological Survey.}

906. A geological map of Ohio. J. A. Bownocker, state geologist. Based on preceding maps by Newberry and Orton. Richmond-Lorraine boundary by Foerste and Morse; glacial boundary and shore of glacial Lake Erie (Lake Maumee) after Leverett. Scale, 8 miles to 1 inch, 1909.

Olcott, Theodore F.

907. A new species of Teleoceras from the Miocene of Nebraska.-Am. Jour. Sci., 4th ser., vol. 28, pp. 403-404, October, 1909.

Oldham, Richard Dixon.

908. The geological interpretation of the earth movements associated with the Californian earthquake of April 18th, 1906.-Geol. Soc., London, Quart. Jour., vol. 65, pt. 1, pp. 1-16, 5 figs., February, 1909.

\section{Ontario, Bureau of Mines.}

909. Visit [of the British Association for the Advancement of Science, Winnipeg Meeting, 1909] to Cobalt and Sudbury, August 17th to August 20th. Toronto, 1909. $31 \mathrm{pp}$., illus.

Describes the Cobalt and Sudbury (Ontario) mineral areas, giving data upon the geology, and the occurrence, relations, and genesis of the ores.

General index of the reports of the Bureau of Mines of Ontario, Volumes I to XVI (1891-1907).--See Nicolas, F. J., no. 899.

Ordóñez, Ezequiel.

910. Physical and geological features of Mexico mining.-Min. World, vol. 31, p. 15, July 3, 1909.

Gives a general account of the physiography and geology of Mexico and the general mode of occurrence of ore deposits.

911. Le Metlacueyatl, Mexique.-Ann. Géog., Paris, ann. 18, pp. 356-361, July 15, 1909.

Describes the physiographic features and the kinds and disposition of volcanic rocks forming its surface. 
Orton, Edward, jr.

912. The Mills moraine, with some general remarks on the glaciation of the Longs Peak region of Colorado.-Abstract: Science, new ser., vol. 29, pp. 751-752, May 7, 1909.

Osborn, Henry Fairfield.

913. Cenozoic mammal horizons of western North America, with faunal lists of the Tertiary Mammalia of the West.-U. S. Geol. Survey, Bull. 361, 138 pp., 3 pls., 15 figs., 1909.

Describes the general geology and climatic history of the Tertiary and Pleistocene of western North America and the character, origin, distribution, and relations of the various mammalian faunas and discusses their homotaxial relations and correlation.

9.14. The epidermis of an iguanodont dinosaur.-Science, new ser., vol. 29, May $14,1909$.

Describes a specimen of Irachodon annectens from Converse County, Wyo., preserving part of the epidermal covering.

915. On a skeleton of Trachodon.-Abstract: Science, new ser., vol. 29, rp. 197-198, January 29, 1908.

916. Upon a skull of Bison latifrons.-Abstract: Science, new ser., vol. 29, p. 198, January 29, 1909.

817. The upper Cretaceous iguanodont dinosaurs.-Nature, vol. 81, pp. 160-162, 2 figs., August 5, 1909.

Discusses the habits and restorations.

Osborn, Henry Fairfield, and Matthew, W. D.

918. Geological correlation through vertebrate paleontology by international cooperation. Correlation Bulletin, no. 1. Plan and scope.-New York Acad. Sci., Annals, vol. 19, pt. 1, pp. 41-44, 1909.

Explains the organization of the committee, the method of procedure, and the progress of correlation work.

Osgood, Samuel W.

919. The east Tennessee zinc-mining district.-Eng. and Min. Jour., vol. 87, pp. 401-404, 5 figs., February 20, 1909.

Includes notes on the occurrence of the zinc ores.

O'Sullivan, Owen.

920. Survey of the south coast of Hudson Bay from the Severn River to Cape Henrietta Maria.-Canada, Geol. Survey, Summ. Rept., 1908, pp. 93-94, 1909.

Includes notes on geologic features of the country traversed.

Outerbridge, Alexander E., jr.

921. The copper mines of Jamaica, British West Indies.-Eng. Mag., vol. 37, pp. 793-805, 11 figs., August, 1909.

922: The mineral wealth of the islands of Newfoundland and Jamaica.-Franklin Inst., Jour, vol. 168, pp. 457-469, 9 figs., December, 1909.

Overspeck, L. S.

The iron deposits of the Black Hills, South Dakota.-See Cooledge and Overspeck, no. 284.

Pack, R. W.

923. Notes on echinoids from the Tertiary of California.-California, Univ., Dept. Geology, Bull., vol. 5, no. 18, pp. 275-283, 2 pls., July, 1909.

Describes Spatangus? pachecoensis n. sp., Scutella fairbanksi, Scutella9 norrisi $\mathrm{n} . \mathrm{sp}$. , Scutaster n. gen., Scutaster andersoni n. sp., A strodapsis fernandoensis n. sp., Astrodapsis antiselli n. var. arnoldi, Echincrachinus excentricus, and Echinarachinus gibbsii. 
Packard, George A.

924. Jefferson Canyon, Nevada.-Min. and Sci. Press, vol. 99, p. 26, July 3, 1909. Includes notes on the local geology.

925. Copper mines and smelteries of Shasta County, California.-Eng. and Min. Jour., vol. 88, pp. 393-399, 9 figs., August 28, 1909.

Includes notes on the geology, occurrence, character, and genesis of the copper ores of Shasta County, Cal.

Paige, Sidney.

926. The Hanover iron-ore deposits, New Mexico.-U. S. Geol. Survey, Bull. 380, pp. 199-214, 2 figs., 1909.

Describes the geography and topography of the Hanover iron-ore district, the general geology, the occurrence, character, and relations of sedimentary and igneous rocks, the metamorphism produced by intrusions, and the distribution, character, and genesis of iron ores.

927. Marble prospects in the Chiricahua Mountains, Arizona.-U. S. Geol. Survey, Bull. 380, pp. 299-311, 2 figs., 1909.

Describes the general geology, the stratigraphy, and the geologic structure, metamorphism in the region, and the occurrence and character of marble.

928. The "rock wall" of Rockwall, Texas.-Science, new ser., vol. 30, pp. 690-691, November 12, 1909.

Describes sandstone dikes at this locality and discusses thẹir ofigin.

Palache, Charles.

929. Note on a crystal form of benitoite.-Am. Jour. Sci., 4 th ser., vol. 27, p. 398, 1 fig., May, 1909.

Palache, C., and La Forge, L.

930. Notes on the crystallography of leadhillite--Am. Acad. Arts and Sci., Proc., vol. 44, no. 17, pp. 435-463, 3 pls., April, 1909.

Palache, C., and Merwin, H. E.

931. Alamosite, a new lead silicate from Mexico.-Am. Jour. Sci., 4th ser., vol. 27, pp. 399-401, 1 fig., May, 1909. Zeitschr. Krystal. und Mineral., Bd. 46, Heft 6, pp. 513-515, 1909.

Describes the occurrence, crystallographic characters, and chemical composition.

932. On connellite and chalcophyllite from Bisbee, Arizona.-Am. Jour. Sci., 4th ser., vol. 28, pp. 537-540, December, 1909.

Palache, Charles, and Wood, H. 0.

933. Crystallographic notes on minerals from Chester, Mass.-Am. Acad. Arts and Sci., Proc., vol. 44, no. 22, pp. 641-652, 1 pl., May, 1909.

Palmer, Chase.

934. Arizonite, ferric metatitanate.-Am. Jour. Sci., 4th ser., vol. 28, pp. 353-356, 1 fig., October, 1909.

Describes the characters, crystallography, and composition of the mineral obtained from a pegmatite dike near Hackberry, Ariz.

Palmer, George Thomas.

935. The medicinal springs of Illinois.-Illinois State Geol. Survey, Bull. no. 10, pp. 62-75, 1909.

Palmer, William.

936. Description of a new species of leatherback turtle from the Miocene of Maryland.-U. S. Nat. Mus., vol. 36, pp. 369-373, 1 pl., 1909.

Describes Psephophorus calvertensis n. sp. 
Pardee, J. T.

937. Faulting and vein structure in the Cracker Creek gold district, Baker County, Oregon.-U. S. Geol. Survey, Bull. 380, pp. 85-93, 3 figs., 1909.

Describes the genoral features, the stratigraphy, the geologic structure, and the vein system, particularly its faulting.

\section{Paredes, Trinidad.}

938. Apuntes sobre un criadero de cobre en Cerro Secn, E. de Guerrero.-Soc. Geol. Mexicana, Bol., t. 5, pp. 103-106, 1 pl., 1909.

Describes the geology, occurrence, and relations of a copper deposit at Cerro Seco, in the State of Guerrero, Mexico.

939. Estudio hidrológico de la región de Rioverde y Arroyo Seco en los Estados de San Luis Potosi y Querétaro.-Mexico, Inst. Geol., Parerg., t. 2, no. 8, pp. 291-337, 2 pls., 1909.

Describes the hydrology of the region stated. Includes an account of the geology.

940. Estudio hidrologico del Valle de Ixmiquilpan, Estado de Hidalgo.-Inst. Geol. Mexico, Parerg., t. 3, no. 3, pp. 141-172, 8 pls., 1909.

Describes the physiographic features, general geology, the Cretaceous and Tertiary formations, the geologic history, and the hydrology of the Valley of Ixmiquilpan, State of Hidalgo, Mexico.

Parker, Edward W.

Coal fields of the United States.-See Campbell and Parker, no. 191.

Parks, William Arthur.

941. Notes on the ophiurian genus, Protaster, with description of a new species.Canadian Inst., Trans., vol. 8, pt. 3, pp. 363-372, 1 pl., April, 1909.

Discusses the characters of the genus, and the generic position of various species referred to it and describes Protaster whiteavesianus n. sp., from the Trenton of Ontario.

942. Note on the ornamentation of Periglyptocrinus priscus.-Ottawa Naturalist, vol. 23, no. 9, pp. 153-155, 1 pl., December, 1909.

Patton, Horace B.

943. The Montezuma mining district of Summit County, Colorado.-Colorado Geol. Survey, 1st Report,.1908, pp. 105-144, 4 pls., 1 fig., 1909.

Describes the general geology and the rocks of the area, the vein systems, and the occurrence and relations of gold, silver, lead, zinc, and iron ores.

Peale, A. C.

944. On the application of the term Laramie.-Am. Jour. Sci., 4th ser., vol. 28, pp. 45-58, July, 1909.

Peet, C. A.

945. Green River dil fields in Wayne County, Utah.-Salt Lake Min. Rev., vol. 11, no. 18, pp. 19-21, 6 figs., December 30, 1909.

Penck, Albrecht F. K.

946. North America and Europe; a geographical comparison.-Science, new ser., vol. 29, pp. 321-329, February 26, 1909. Jour. Geog., vol. 8, no. 4, pp. 73-83, December, 1909. Scottish Geog. Mag., vol. 25, no. 7, pp. 337346, July, 1909.

947. The antiquity of man.-Abstract: Science, new ser., vol. 29, pp. 359-360, February 26, 1909.

56693ํ-Bull. 444:-10 -6 
Pepperberg, Leon J.

948. Cement material near Havre, Montana.-U. S. Geol. Survey, Bull. 380, pp. 327-336, 1 fig., 1909.

Describes the geology of the district and the occurrence and composition of limestone and shale.

949. The Milk River coal field, Montana.-U. S. Geol. Survey, Bull. 381-A (advance chapter), pp. 78-103, 1 pl. (map), 1 fig., 1909.

Describes the topography and geography, the stratigraphv and structure of the field, the character and distribution of the coal beds, and the properties and composition of the coal.

Peragallo, Oreste.

950. San Ygnacio mill and mine, Chihuahua, Mexico.-Eng. and Min. Jour., vol. 88, pp. 1263-1265, 3 figs., December 25, 1909.

Includes notes on the local geology and the occurrence, character, and origin of the silver-lead-zinc ores.

\section{Perrine, I.}

Oil and gas in northwestern Louisiana, with special reference to the Caddo field.-See Harris, Perrine, and Hopper, no. 514.

Peterson, O. A.

951. A revision of the Entelodontidæ.-Carnegie Mus., Mem., vol. 4, no. 3, pp. 41-156, 9 pls.; 65 figs., 1909.

Includes an account of the Agate Spring fossil quarries in western Nebraska.

952. A new genus of carnivores from the Miocene of western Nebraska.-Science, new ser., vol. 29, pp. 620-621, April 16, 1909.

Proposes the name Daphænodon for the material described as A mphicyon superbus.

Phalen, William Clifton.

Mineral resources of the United States, 1908: Bauxite and aluminum; abrasive materials; salt and bromine; sulphur and pyrite.-See no. 1170.

Phillips, William B.

953. The South Lorraine silver district, Ontario.-Eng. and Min. Jour., vol. 87, pp. 214-215, January 23, 1909.

Includes a brief account of the geology of the district and the occurrence of the silver ore.

954. Condition of the quicksilver industry in Texas.-Eng. and Min. Jour., vol. 88, pp. 1022-1024, November 20, 1909.

Includes notes on the occurrence of the ore.

955. Iron ores of Llano County, Texas.-Manufacturers' Record, vol. 56, no. 1, p. 49, July 15, 1909.

Platt, James M.

956. The turquoise mining ciistrict, Arizona.-Eng. and Min. Jour., vol. 87, p. 213, January 23, 1909.

957. The Zacualpan district, Mexico.-Eng. and Min. Jour., vol. 88, pp. 670-671, October 2, 1909.

Includes notes on the occurrence and character of the silver ores of the Zacualpan district, State of Mexico, Mexico.

Pogue, Joseph E.

958. Crystallographic notes on calcite.-Smithsonian Misc. Coll., vol. 52 (Quart. Issue, vol. 5, pt. 4), pp. 465-468, 2 pls., 1909.

959. On a remarkable cube of pyrite, carrying crystallized gold and galena of unusual habit.-Smithsonian Misc. Coll., vol. 52 (Quart. Issue, vol. 5, pt. 4), pp. 477-483, 1 pl., 5 figs., 1909. 
Pogue, Joseph E.-Continued.

960. Geology and structure of the ancient volcanic rocks of Davidson County, North Carolina.-Am. Jour. Sci., 4th ser., vol. 28, pp. 218-238, 3 figs., September, 1909.

Describes the general geology of the region, the lithology, structural features, and geologie history.

Pogue, J. L.

Calcite crystals from Kellys Island, Lake Erie.-See Ford and Pogue, no. 417.

Crystals of datolite from Bergen Hill, New Jersey.-See Ford and Pogue, no. 418 .

Poole, Henry S.

961. Pre-Cambrian volcanic bombs from near Lake Ainslie, Inverness Co., N. S.-Nova Scotian Inst. Sci., Proc. and Trans., vol. 11, pt. 3, pp. 339-346, 1908 .

962. A section of Carboniferous rocks in Cumberland County, Nova Scotia: (1) Detailed section of rocks from West Ragged Reef to the Joggins mines and Minudie, by Sir William E. Logan (republished); and (2) From Schulie to Spicer Cove, by Hugh Fletcher.-Nova Scotian Inst. Sci., Proc. and Trans., vol. 11, pt. 3, pp. 417-550, 3 pls. (maps and sections), 1908.

Pratt, Joseph Hyde.

963. Biennial report of the state geologist, 1905-1906.-North Carolina Geol. Survey, 60 pp., 1907.

964. The mining industry in North Carolina during 1907, with special report on the mineral waters.-North Carolina Geol. and Econ. Survey, Econ. Paper no. 15, 176 pp., 13 pls., 4 figs., 1908.

965. Biennial report of the state geologist, 1907-1908.-North Carolina Geol. Survey, 60 pp.; 1908 [1909?].

966. New occurrence of monazite in North Carolina.-Elisha Mitchell Sci. Soc., Jour., vol. 25, no. 2, pp. 74-77, June, 1909.

967. The mineral production in North Carolina during 1908.-Elisha Mitchell Sci. Soc., Jour., vol. 25, no. 4, pp. 164-167, December, 1909.

Pratt, Joseph Hyde, and Sterrett, Douglas B.

968. Monazite and monazite mining in the Carolinas.-Am. Inst. Min. Eng., Bull., no. 30, pp. 483-511, 8 figs., June, 1909.

Prindle, Louis M.

969. The Fortymile quadrangle, Yukon-Tanana region, Alaska.-U. S. Geol. Survey, Bull. 375, 52 pp., 5 pls., 2 figs., 1909.

Describes the general physical and geologic features, the occurrence, character, and relations of pre-Ordovician, Devonian, Carboniferous, Tertiary, and Quaternary formations, and the gold deposits.

Prindle, L. M., and Katz, F. J.

970. The Fairbanks gold placer region, Alaska.-U. S. Geol. Survey, Bull. 379, pp. 181-200, 1 pl. (map), 1909.

Prosser, Charles S.

Nomenclature and subdivision of the upper Siluric strata of Michigan, Ohio, and western New York.-See Lane and others, -no. 733.

Prouty, William F.

971. The Coosa coal field of Alabama.-Eng. and Min. Jour., vol, 88, pp. 921-923, 3 figs., November 6, 1909. 
Purdue, A. H.

972. The slates of Arkansas.-Arkansas, Geol. Survey, pp. 1-95, 7 pls., 1909.

973. Structure and stratigraphy of the Ouachita Ordovician area, Arkansas.Abstract: Geol. Soc. America, Bull., vol. 19, pp. 556-557, 1909.

\section{Quackenbush, L. S.}

974. Notes on Alaskan mammoth expeditions of 1907 and 1908.-Am. Mus. Nat. Hist., Bull., vol. 26, pp. 87-130, 9 pls., 10 figs., 1909.

Includes notes on the occurrence of varicus mammals.

Ramsay, J. D.

975. The Maple Mountain mining district [Montreal River mining division] of Ontario.-Canadian Min. Jour., vol. 30, pp. 526-527, 3 figs., September 1, 1909.

Includes notes on the geology of the district and the occurrence of the silver ores.

Rankin, G. S.

The binary systems of alumina with silica, lime, and magnesia.-See Shepherd and Rankin, no. 1056.

Ransome, Frederick Leslie.

976. The geology and ore deposits of Goldfield, Nevada.-U. S. Geol. Survey, Prof. Paper 66, 258 pp., 35 pls., 34 figs., 1909.

Describes the occurrence and relations of pre-Tertiary sedimentary rocks and Tertiary igneous rocks and sedimentary deposits, the geologic structure and history, the mineralogy , and the distribution, geologic relations, and genesis of the ore bodies, and gives a detailed account of the mines.

977. The Hornsilver district, Nevada.-U. S. Geol. Survey, Bull. 380, pp. 41-43, 1909.

Gives notes upon the local geology and the gold and silver ores.

978. Round Mountain, Nevada.-U. S. Geol. Survey, Bull. 380, pp. 44-47, 1. fig., 1909.

Describes briefly the general geology, the occurrence and-character of the ores, yielding principally gold, and the mining developments.

978. The Yerington copper district, Nevada.-U. S. Geol. Survey, Bull. 380, pp. 99-119, 2 figs., 1909.

Describes the general geology, the occurrence, character, and relations of pre-Tertiary and Tertiary rocks, the mines and prospects, and the character of the copper deposits.

980. Notes on some mining districts in Humboldt County, Nevada.-U. S. Geol. Survey, Bull. 414, 75 pp., 1 pl. (map), 7 figs., 1909.

Describes the mining developments of the Humboldt region, the general geology and petrology of the mining districts, the occurrence, relations, and character of the ore deposits, mainly gold, silver, copper, antimony, nickel, and cobalt, and the mineralogy of the ore deposits.

981. Characteristics of some ore deposits of southern Humboldt County, Nevada.-Abstract: Science, new ser., vol. 30, pp. 972-973, December 31, 1909.

[Petrography of the Newark group in the Trenton quadrangle.]-See Bascom and others, no. 74 .

Raymond, Percy E.

982. The fauna of the upper Devonian in Montana. Part I. The fossils of the red shales.-Carnegie Mus., Annals, vol. 5, pp. 141-158, 6 pls., 5 figs., 1909.

983. Some sections of the Conemaugh series between Pittsburgh and Latrobe, Pennsylvania.-Carnegie Mús., Annals, vol. 5, pp. 166-177, 3 pls., 1909.

984. Notice of two new horizons for marine fossils in western Pennsylvania.Science, new ser., vol. 29, pp. 940-941, June 11, 1909. 
Raymond, Rossiter W.

985. Biographical notice of James Duncan Hague.-Am. Inst. Min. Eng., Bull., no. 26, pp. 109-117, 1 pl. (port.), February, 1909.

Dip and pitch.-Am. Inst. Min. Eng., Trans., vol. 39, pp. 326-327, 898-916, 2 figs., 1909. See no. 856 of the bibliography for 1908, U, S. Geol. Survey, Bull. 409, p. 69 .

Raymond, R. W., and Ingalls, W. R.

986. The mineral wealth of the Cordilleras.-Eng. and Min. Jour., vol. 88, pp. 678-680, October 2, 1909.

887. The mineral wealth of America.-Am. Inst. Min. Eng., Bull., no. 27, pp. 249-264, 1909.

Raymond, R. W., and others.

988. Dip and pitch.-Am. Inst. Min. Eng., Bull., no. 26, pp. 197-209, February, 1909.

Discusses the application of these terms to the position of ore bodies.

Reagan, Albert B.

989. Some notes on the Olympic Peninsula, Washington.-Kansas Acad. Sci., Trans., vol. 22, pp. 131-238, 6 pls., 4 figs., 1 map, 1909.

990. A probable origin of the numerous depressions in the mesa south of the arroyo formed by the outlet of Tijeras Canyon in the Sandias near Albuquerque, New Mexico.--Indiana Acad. Sci., Proc., 1908, p. 165, 1909.

Reed, W. J.

The Madill oil pool, Oklahoma.-See Taff and Reed, no. 1132.

\section{Reid, Harry Fielding.}

991. Mr. Manson's theory of geological climates.-Science, new ser., vol. 29, pp. 27-29, January 1, 1909.

992: Geometry of faults.-Geol. Soc. America, Bull., vol. 20, pp. 171-196, 12 figs., May, 1909.

Discusses the nomenclature and classification of faults, the nature of the observations necessary to determine completely the movement at a fault, and how this movement can be worked out from the observations.

993. Seismological notes.-Am. Philos. Soc., Proc., vol. 48, pp. 303-312, 4 figs., 1909. Abstract: Science, new ser., vol. 29, p. 833, May 21, 1909.

Discusses conditions preceding and leading to tectonic earthquakes, and some characteristics of seismologic instruments; and suggests establishing a National Seismological Bureau.

994. The variations of glaciers, XIV.--Jour. Geology, vol. 17, no. 7, pp. 667-671, 1909:

\section{Reynoso, José J.}

995. El mineral de Naica, Estado de Chihuahua.-Soc. Geol. Mexicana, Bol, t. 5, pp. 8-9, 1909.

Gives notes upon the geology and the lead and iron deposits of Naica, State of Chihuahua, Mexico.

Richards, Ralph W.

996. The Dragoon, Arizona, tungsten deposits.-Min. Science, vol. 57, pp. 93-94, January 23, 1908.

997. The central part of the Bull Mountain coal field, Montana.-U. S. Geol. Survey, Bull. 381-A (advance chapter), pp. 56-77, 2 pls. (map), 1909.

Describes the general features of the field, the stratigraphy and the structure, the character and distribution of the coal beds, and the qualities and composition of the coal. 
Richardson, George Burr.

998. Description of the El Paso quadrangle, Texas.-U. S. Geol. Survey, Geol. Atlas U. S., El Paso folio (no. 166), library edition, 11 pp., 3 pls. (maps and illustrations sheet), 8 figs.; field edition, 86 pp., 2 folded maps, 7 pls., 8 figs., 1909.

Describes the geography, the occurrence, character, and relations of pre-Cambrian, Cambrian, Ordovician, Silurian, Carboniferous, Cretaceous, and Quaternary formations, and of igneous rocks, the geologic structure, the geologic history, and the mineral resources.

999. The Harmony, Colob, and Kanab coal fields, southern Utah.-U. S. Geol. Survey, Bull. 341, pp. 379-400, 1 pl. (map), 1909.

Describes the location and topography, the stratigraphy and structure of the field, the occurrence and character of the coal beds, and the quality and composition of the coals.

1000. Reconnaissance of the Book Cliffs coal field between Grand River, Colorado, and Sunnyside, Utah.-U. S. Geol. Survey, Bull. 371, 54 pp., 10 pls., 1 fig., 1909.

Describes the topography, stratigraphy, including Cretaceous and Tertiary formations, and structure of the field, and the occurrence, character, and development of the coal beds and quality of the coal.

Rickard, Forbes.

1001. Gold ore near Newcastle, Colorado.-Min. and Sci. Press, vol. 99, p. 503, 1 fig., October 9, 1909.

Includes notes on the local geology.

Rickard, T. A.

1002. Alaska and the Yukon.-Min. and Sci. Press, vol. 98, pp. 15-22, 7 figs., January 2, 1909.

Describes gold mining and the occurrence of placer gold in Alaska.

Ries, Heinrich.

1003. The geological investigation of clays.-Min. World, vol. 30, p. 1118, June 12 , 1909.

Riggs, Elmer S.

1004. Loup Fork beds of eastern Wyoming.-Abstract: Science, new ser., vol. 29, p. 196, January 29, 1909.

Ritter, Etienne A.

1005. Ore formation in the Wonder district, Nevada.-Eng. and Min. Jour., vol. 87, pp. 289-292, 13 figs., February 6, 1909.

Describes the geology of the district, the veins, and the character and structure of the silver ores.

Roberts, Milnor.

1006. A wonderland of glaciers and snows.-Nat. Geog. Mag., vol. 20, pp. 530538, 9 figs., June, 1909.

Describes features of Mount Rainier National Park, Washington.

Robertson, William Fleet.

1007. Report of [British Columbia] Bureau of Mines.-British Columbia, Ann. Rept: Minister of Mines, for 1908, Victoria, B. C., 1909. 269 pp., pls., and maps.

Includes notes on the geology and occurrence of various ores in British Columbia.

Robles, R.

Geologic study of the Sierra of Guanajuto.-See Villarello, Flores, and Robles, no. 1192. 
Roddy, H. Justin.

1008. The lower Cambrian of Lancaster County, Pa.-Abstract: Science, new ser., vol. 30, p. 415, September 24, 1909.

Notes the discovery of lower Cámbrian fossils.

Roe, A. D.

1009. A mineral resembling meerschaum from the serpentine range of Hampden County, Mass., with descriptions of interesting included crystals.Minnesota Acad. Sci., Bull., vol. 4, no. 2, pp. 268-276, 1 pl., 1906.

Rogers, Austin F.

1010. Pyrite crystals from Bingham, Utah.-Am. Jour. Sci., 4th ser., vol. 27, pp. 467-468, 1 fig., June, 1909.

Coal measures faunal studies: faunal divisions of the Kansas coal measures.-See Beede and Rogers, no. 95.

Rogers, A. P.

1011. The new oil field in Utah.-Eng. and Min. Jour., vol. 87, p. 989, 1 fig., May $15,1909$.

Rogers, R. V.

1012. The geological survey of northeastern Chihuahua, Mexico.-Mexican Min. Jour., vol. 9, no.. 5, p. 24, November, 1909.

Rohwer, S. A.

1013. The fossil Ceropalidæ of Florissant, Colorado.-Psyche, vol. 16, no. 2, pp. 23-28, April, 1909.

1014. Three new fossil insects from Florissant, Colorado.-Am. Jour. Sci., 4th ser., vol. 28, pp. 533-536, December, 1909.

Root, W. A.

1015. The Lida mining district of Nevada.-Min. World, vol. 31, pp. 123-125; 12 figs., July 10, 1909.

Includes notes on the occurrence and character of the ore deposits.

Rowe, Jesse Perry.

1016. The Cœur d'Alene mining district.-Min: World, vol. 30, pp. 11-14, 89-92, 117-120, 318-320, 357-358, 428-430, 18 figs., 1909.

1017. Development of Montana's sapphire mines.-Min. World, vol. 31, pp. 921923, 8 figs., November 6, 1909.

1018. The Roundup coal mines of Montana.-Min. World, vol. 31, pp. 1057-1061, 10 figs,, November 27, 1909.

Includes notes on the occurrence and character of the coals.

Ruedemann, Rudolf.

1018. Types of inliers observed in New York.-New York State Mus., Bull., 133 pp. 164-193, 32 figs., 1909.

Discusses the definition of inlier, and describes various types and their mode of formation with especial reference to occurrences in New York.

1020. Some marine algæ from the Trenton limestone of New York.-New York State Mus., Bull. 133, pp. 194-216, 3 pls., 5 figs., 1909.

1021. Note on Dictyonema websteri ( $=$ D. retiforme).--Nova Scotia Inst. Sci., Proc. and Trans., vol. 11, pt. 4, p. xlvii, 1908.

Ruhl, Otto.

1022. History of southeast Missouri lead district.-Min. World, vol. 30, pp. 721724, 5 figs., April 17, 1909.

Includes notes on the geology and the occurrence of the lead ores. 
Rush, W. W.

1023. Bear River district [British Columbia].-Min. and Sci. Press, vol. 99, p. 152, 1 fig., July 31, 1909.

Includes notes on the local geology and occurrence of the ores.

Salisbury, Rollin D.

1024. Physical geography of the Pleistocene with special reference to Pleistocene conditions.-Jour. Geology, vol. 17, no. 7, pp. 589-599, 1909.

Description of the Philadelphia district.-See Bascom and others, no. 74.

Description of the Trenton quadrangle, New Jersey-Pennsylvania.-See Bascom and others, no. 75 .

Sanford, Samuel.

1025. The topography and geology of southern Florida.-Florida State Geol. Survey, 2d Ann. Rept., pp. 175-231, 2 pls., 1 fig., 1909.

Mineral resources of the United States, 1908: Mineral waters.-See no. 1170.

- Sargent, R. H.

1026. The monarchs of Alaska.-Nat. Geng. Mag., vol. 20, pp. 611-623, 9 figs., July, 1909.

Describes physiographic features of Alaska.

Savage, T. E.

1027. The Ordovician and Silurian formations in Alexander County, Illinois.Am. Jour. Sci., 4th ser., vol. 28, pp. 509-519, December, 1909.

Sayles, Robert W.

1028. Glacial clays of the Maine coast.-Science, new ser., vol. 30 , p. 968 , December $31,1909$.

Notes the discovery of ophiuroids in the "upper clay" near Rockland, Me.

Schaller, Waldemar $\mathrm{T}$.

1029. Some calcite crystals with new forms.-Washington Acad. Sci., Proc., vol. 11, no. 1, pp. 1-16, 8 figs., 1909.

The mercury minerals from Terlingua, Texas.-See Hillebrand and Schaller, no. 565 .

Scharff, R. F.

1030. On the evidences of a former land-bridge, between northern Europe and North America.-Roy. Irish Acad., Proc., vol. 28, sect. B, no. 1, pp. 1-28, 4 figs., 1909.

1031. On an early Tertiary land connection between North and South America.Am. Naturalist, vol. 43, pp. 513-531, September, 1909.

Scheffel, E. R.

1032. Significance of drainage changes near Granville, Ohío.-Denison Univ., Sci. Lab., Bull., vol. 14, pp. 157-174, 2 figs., 1909.

Considers that drainage changes may have been caused by tilting of the land in preglacial time rather than by the advance of glaciers.

Schlundt, Herman, and Moore, Richard B.

1033. Radioactivity of the thermal waters of Yellowstone National Park.-U. S. Geol. Survey, Bull. 395, 35 pp., 4 pls., 7 figs., 1909.

Schrader, Frank Charles.

1034. Mineral deposits of the Cerbat Range, Black Mountains, and Grand Wash Cliffs, Mohave County, Arizona.-U. S. Geol. Survey, Bull. 397, 226 pp., 16 pls., 37 figs., 1909.

Describes the physiographic features and general geology, the occurrence of the ores, gold, silver, lead, copper, and zinc, and the mining developments. 
Schubert, E. A.

1035. The mineral resources of Virginia.-Am. Min. Congress, 11th Ann. Sess., Papers and Addresses, pp. 121-145, 1909.

Schuchert, Charles.

1036. Paleogeography of North America.-Abstract: Science, new ser., vol. 29, pp. 629-630, April 16, 1909.

1037. Obituary: Joseph Frederick Whiteaves.-Am. Jour. Sci., 4th ser., vol. 28, p. 508, November, 1909.

1038. Obituary, Hugh Fletcher.-Am. Jour. Sci., 4th ser., vol. 28, p. 508, November, 1908.

The Silurian section at Arisaig, Nova Scotia: Correlation.-See Twenhofel, no. 1158.

Schultz, A. R.

1039. The northern part of the Rock Springs coal field, Sweetwater County, Wyoming.-U. S. Geol. Survey, Bull. 341, pp. 256-282, 2 pls. (maps), 1909.

Describes the topographic features, stratigraphy, and geologic structure of the field, the quality and composition of the coals, and the mining developments.

Schwarz, E. H. L.

1040. The probability of large meteorites having fallen upon the earth.-Jour. Geology, vol. 17, no. 2, pp. 124-135, 3 figs., 1909.

Scott, J. G.

1041. Coal in Alberta.-Quebec, Soc. Géog., Bull., vol. 3, no. 4, pp. 41-44, May, 1909.

Notes the discovery of bituminous coal in northern Alberta.

Scott, W. A.

1042. Mining on Prince of Wales Island, Alaska.-Min. and Sci. Press, vol. 98, pp. 885-886, 3 figs., June 26, 1909.

Includes notes on the occurrence of the copper ores.

1043. Haines district, Alaska.-Min. and Sci. Press, vol. 99, pp. 198-199, 1 fig., August 7, 1909.

Includes notes on the local geology and the occurrence of placer.gold.

See, T. J. J.

1044. The past history of the earth as inferred from the mode of formation of the solar system.-Am. Philos. Soc., Proc., vol. 48, pp. 119-128, 1909.

Sellards, E. H.

1045. Fossil plants of the upper Paleozoic of Kansas.-Kansas, Univ. Geol. Survey, vol. 9, pp. 386-480, 26 pls., 2 figs., 1908.

Describes fossil plants from the coal measures and Permian formations of Kansas.

1046. Cockroaches of the Kansas coal measures and of the Kansas Permian.Kansas, Univ. Geol. Survey, vol. 9, pp. 501-541, 14 pls., 1908.

1047. Types of Permian insects. Part III.-Am. Jour. Sci., 4th ser., vol. 27, pj. 151-173, 28 figs., February, 1909.

1048. Administrative report.-Florida State Geol. Survey, 2d Ann. Rept., pp. 13-19, 1909.

1049. Mineral industries [of Florida].-Florida State Geol. Survey, 2d Ann. Rept., pp. 233-251, 5 pls., 1909.

Sellards, E. H., and Gunter, Herman.

1050. The fuller's earth deposits of Gadsden County, Florida. With notes on similar deposits found elsewhere in the State.-Florida State Geol. Survey, 2d Ann. Rept., pp. 253-291, 4 pls., 2 figs., 1909. 
Shaler, Nathaniel Southgate.

1051. The autobiography of Nathaniel Southgate Shaler, with a supplementary memoir by his wife. Boston, Houghton Mifflin Company, 1909. 481 pp., illus.

Includes a list of his writings.

Shannon, C. W.

1052. Soil survey of Dubois, Perry, and Crawford counties, Indiana.-Indiana, Dept. Geology and Nat. Res., 33d Ann. Rept., pp. 277-342, 10 pls., 1 fig., 1909.

\section{Shattuck, George B.}

1053. Concentration versus transportation: a need of accurate measurements of stream work.-Jour. Geography, vol. 7, no. 7, pp. 158-163, 4 figs., March, 1909.

Shaw, E. Wesley.

1054. The Glenrock coal field, Wyoming.-U. S. Geol. Survey, Bull. 341, pp.151164, 1 pl. (map), 1 fig., 1909.

Describes the topography and stratigraphy of the field, and the occurrence, character, and mining of the coals.

Shaw, S. F. .

1055. Mining and milling in Tombstone district, Arizona.-Min. World, vol. 30, pp. 589-590, 4 figs., March 27, 1909.

Includes notes on the geology and occurrence of gold and silver ores.

Shepherd, E. S., and Rankin, G. S.

1056. The binary systems of alumina with silica, lime, and magnesia; with optical study, by Fred. Eugene Wright.-Am. Jour. Sci., 4th ser., vol. 28, pp. 293-333, 7 figs., October, 1909.

Sheridan, Jo. E.

1057. The coal mines and plant of the Stag Canon Fuel Co., Dawson, New Mexico.-Am. Inst. Min. Eng., Bull., no. 30, pp. 537-564, 15 figs., June, 1909.

Describes briefly the geology, character, and occurrence of the coal beds.

Sherzer, William Hittell.

Nomenclature and subdivision of the upper Siluric strata of Michigan, Ohio, and western New York.-See Lane and others, no. 733.

Sherzer, W. H., and Grabau, A. W.

1058. New upper Siluric fauna from southern Michigan.-Geol. Soc. America, Bull., vol. 19, pp. 540-553, 1 fig., 1909.

Discusses the relations and correlations of various Silurian-formations and gives lists of fossils from different beds.

Shideler, William.

1059. The Addison Creek exposure.-The Miami Student, Oxford, Ohio, vol. 26, pp. 308-310, 1 pl., June, 1907.

Describes exposures of Richmond strata near Oxford, Ohio, and gives a list of the fossils collected.

Shimek, B.

1060. Aftonian sands and gravels in western Iowa.-Geol. Soc. America, Bull., vol. 20 , pp. 399-408, 5 pls., December, 1909.

Shimer, Hervey Woodburn.

North American index fossils: Invertebrates.-See Grabau and Shimer, no. 477 . 
Shumard, B. F.

Descriptions of new fossils from the Tertiary formation of Oregon and Washington territories and the Cretaceous of Vancouver Island, collected by Dr. John Evans, United States geologist, under instructions from the Department of the Interior (reprinted from St. Louis Acad. Sci., Trans., vol. 1, pp. 120-123, 1858).-U. S. Geol. Survey, Prof. Paper 59, pp. 186-188, 1909.

Shurick, A. T.

1061. The Great Falls coal field in Montana.-Eng. and Min. Jour., vol. 87, pp. 587-590, 3 figs., March 20, 1909.

Includes a brief account of the geology and the character of the coal.

Sibley, R. Roy.

1062. The Copper Creek mining district, Arizona.-Min. World, vol. 30, pp. 477480, 4 figs., March 13, 1909.

Includes notes on the occurrence of the copper deposits.

Siebenthal, Claude E.

Mineral resources of the United States, 1908: Lead; zinc, cadmium.-See no. 1170.

Geology and mineral resources of the Laramie Basin, Wyoming.-See Darton and Siebenthal, no. 313 .

Simmons, Jesse.

1063. Tin in the Black Hills of South Dakota.-Min. World, vol. 30, pp. 925-926, 1 fig., May 15, 1909.

Includes notes upon the geology and occurrence of the tin ores.

1064. The mother lode of the Black Hills [South Dakota].-Min. World, vol. 31, p. 126, July 10, 1909.

Gives notes on the occurrence of the ore deposits.

Sinclair, W. J.

1065. The Washakie, a volcanic ash formation.-Am. Mus. Nat. Hist., Bull., vol. 26, pp. 25-27, 1909.

Describes the materials composing the Washakie formation of southern Wyoming and shows that they differ from those of the Bridger formation; and concludes that the two formations are not contemporaneous.

Singewald, Joseph T., jr.

1066. The iron ores of Maryland.-Econ. Geology, vol. 4, no. 6, pp. 530-543, 1 fig., 1909.-Abstract: Science, new ser., vol. 29, pp. 633-634, April 16, 1909.

Sivyer, Leonard D.

1067. Geology of Globe, Arizona.-Los Angeles Min. Rev., vol. 25, no. 11, pp. 6-7, 1 fig. (sections), March 13, 1909.

Sloan, Earle.

1068. A summary of the mineral resources of South Carolina. Issued by [South Carolina], Dept. Agriculture, Commerce, and Immigration. Columbia, S. C., 1907. 66 pp., illus.

Reprinted with some changes and additions in Handbook of South Carolina, Columbia, 1907. See no. 2218 in Bull. 372, U. S. Geol. Survey.

Slocum, Arthur Ware.

1069. New echinoids from the Ripley group of Mississippi.-Field Mus. Nat. Hist., Geol. Ser., vol. 4, no. 1, pp. 1-16, 3 pls., 2 figs., May 15, 1909. 
Smith, Arthur L.

1070. Delta experiments.-Am. Geog. Soc., Bull., vol. 41, no. 12, pp. 729-742 8 figs., December, 1909.

Discusses the form and mode of formation of several experimental deltas, and the necessary and modifying conditions of delta formation.

Smith, Burnett.

1071. Note on the Miocene drumfish, Pogonias multidentatus Cope.-Am. Jour. Sci., 4th ser., vol. 28, pp. 275-282, 13 figs., September, 1909.

1072. On some Dinichthyid armor plates from the Marcellus shale.-Am. Naturalist, vol. 43, pp. 588-597, 3 figs., October, 1909.

Describes fish remains from the Marcellus shale in the vicinity of Syracuse, N. Y., identified with Dinichthys halmodeus (Clarke).

1073. Dikes in the Hamilton shale near Clintonville, Onondaga County, New York.-Science, new ser., vol. 30, p. 724, November 19, 1909.

Records the discovery of two dikes, which are briefly described, at a locality 12 miles southwest of Syracuse, N. Y.

Smith, Carl D.

1074. The Washburn lignite field, North Dakota.-U. S. Geol. Survey, Lull. 381-A (advance chapter), pp. 15-25, 1 pl. (map), 1 fig., 1909.

Describes the general features of the field, the various exposures of lignite beds, and the character of the lignite.

1075. The Fort Berthold Indian Reservation lignite field, North Dakota.-U. S. Geol. Survey, Bull. 381-A (advance chapter), pp. 26-35, 1 pl. (map), 1909 .

Describes the general features of the field, the stratigraphy and structure, the distribution of the lignite, and its character and uses.

1076. The Fort Peck Indian Reservation lignite field, Montana.-U. S. Geol. Survey, Bull. 381-A (advance chapter), pp. 36-55, 1 pl. (map), 1909.

Describes the topography and stratigraphy of the field, and the character and distribution of the lignite beds.

The Miles City coal field, Montana.-See Collier and Smith, no. 274.

The Sentinel Butte lignite field, North Dakota and Montana.-See Leonard and Smith, no. 761.

Smith, E. Eggleston.

1077. The eastern part of the Great Divide Basin coal field, Wyoming.-U. S. Geol. Survey, Bull. 341, pp. 220-242, 1 pl. (map), 1909.

Describes the general features of the field and the stratigraphy and structure, the occurrence and character of the coal beds, and the quaiity and composition of the coals.

Smith, Ethel M.

1078. A study of volcanic topography.-Jour. Geography, vol. 8, no. 3, pp. 56-61, November, 1909.

Describes the physiographic history of extinct volcanoes of the United States.

Smith, F. C.

1079. What is an ore?-Min. and Sci. Press, vol. 98, p. 614, May 1, 1909.

Presents a definition of the term "ore."

Smith, George L.

1080. The Carboniferous section of southwestern Iowa.-Iowa Geol. Survey, vol. 19, pp. 605-657, 4 pls., 1 fig., 1909.

Describes the coal measures stratigraphy of southwestern Iowa and gives notes upon the range of certain fossils. 
Smith, George Otis.

1081. Geology of the Kennebec River basin [Maine].-U. S. Geol. Survey, WaterSupply and Irrig. Paper no. 198, pp. 4-9, 1907.

1082. Thirtieth annual report of the Director of the United States Geological Survey to the Secretary of the Interior for the fiscal year ended June 30, 1909. Washington, 1909.128 pp., 2 pls. (maps).

A summary of the work of the year, by branches and divisions, with notes on special features, brief descriptions of the publications, and maps showing areas covered by geologic and topographic surveys.

1083. Distribution of the nation's mineral wealth.-Am. Min. Congress, 11th Ann. Sess., Papers and Proc., pp. 247-250, 1909.

\section{Smith, James Perrin.}

1084. Salient events in the geologic history of California.-Science, new ser., vol. 30, pp. 346-350, September 10, 1909.

Outlines the geologic history of California from the Cambrian to the present. Includes a synopsis of Quaternary history in tabular form.

Smith, Philip S.

1085. Recent developments in southern Seward Peninsula, Alaska.-U. S. Geol. Survey, Bull. 379, pp. 267-301, 2 figs., 1909.

Describes development of placer and lode gold deposits. Includes notes on the geology of the region.

1086. The Iron Creek region, Alaska.-U. S. Geol. Survey, Bull. 379, pp. 302-354, 1 pl. (map), 1 fig., 1909.

Describes the general geology, the gravels, and the placer and lode gold deposits.

Snider, L. C.

1087. Soil survey of Daviess County, Indiana.-Indiana, Dept. Geology and Nat. Res., 33d Ann. Rept., pp. 343-357, 3 pls., 1909.

Spalding, W. A.

1088. Mine explosions as related to earthquakes.-Eng. and Min. Jour., vol. 87, pp. 411-413, February 20, 1909; p. 899, May 1, 1909; vol. 88, pp. 562-563, September 18, 1909.

Spencer, Arthur Coe.

1089. The Mine Hill and Sterling Hill zinc deposits of Sussex County; New Jersey.-New Jersey Geol. Survey, Ann. Rept. State Geologist for 1908, pp. 23-52, 6 figs., 1909.

Describes the mining developments, the constitution of the ore, and the characteristics, relations, and origin of the deposits.

Springer, Frank.

1090. A new American Jurassic crinoid.-U. S. Nat. Mus., Proc., vol. 36, pp. 179190, 1 pl., 1909.

Spurr, Josiah Edward.

1091. Scapolite rocks of America.-Am. Jour. Sci., 4th ser., vol. 25, p. 154, February, 1909.

Questions the correctness of his former determination of scapolite rocks in Alaska.

1092. Ore deposition at Aspen, Colorado.-Econ. Geology, vol. 4, no. 4, pp. 301320, 1909.-Min. World, vol. 31, pp. 749-752, October 9, 1909.

Squire, George Hull.

1093. Peculiar local deposits on bluffs adjacent to the Mississippi.-Wisconsin Acad. Sci., Arts, and Letters, vol. 16, pt. 1, no. 3, pp. 258-274, 1 pl., 2 figs., 1908.

Describes the deposits and discusses their origin and mode of formation, 
Stabler, H.

Denudation.-See Dole and Stabler, no. 345.

Denudation in the United States.-See Dole and Stabler, no. 346.

Stanton, Timothy W.

1094. Succession and distribution of later Mesozoic invertebrate faunas in North America.-Jour. Geology, vol: 17, no. 5, pp. 410-423, 1909.

1095. The age and stratigraphic relations of the "Ceratops beds" of Wyoming and Montana.-Washington Acad. Sci., Proc., vol. 11, no. 3, pp. 239-293, August 14, 1909.

Describes the distribution, relations, and faunal character of the "Ceratops beds," and considers them to be of Cretaceous age, while the Fort Union formation, properly restricted, is of early Eocene age.

Stauffer, Clinton R.

1096. The middle Devonian of Ohio.-Ohio Geol. Survey, 4th ser., Bull. 10, 204 pp., 17 pls., November, 1909.

Gives a general discussion of the middle Devonian of Ohio and adjoining States, describes sections and their faunas at various localities in Ohio, discusses the relationship of the middle Devonian faunas of Ohio, and gives notes on and descriptions and figures of species.

Stearns, Jane.

1097. A physiography laboratory.-Jour. Geography, vol. 8, no. 4, pp. 84-89, 7 figs., December, 1909.

Stephenson, L. W.

1098. Cretaceous geology of the Carolinas and Georgia.-Abstract: Science, new ser., vol. 30, pp. 124-125, July 23, 1909.

Sternberg, Charles H.

1099. The life of a fossil hunter. New York, Henry Holt and Company, 1909. $286 \mathrm{pp} ., 1 \mathrm{pl}$. (port.), and 46 figs.

An autobiographical sketch. Includes numerous figures of fossils and restorations.

1100. Expedition to the Laramie beds of Converse County, Wyoming.-Kansas Acad. Sci., Trans., vol. 22, pp. 113-116, 1909.

Describes the beds and gives notes upon the fossils collected from them.

1101. An armored dinosaur from the Kansas chalk.-Kansas Acad. Sci., Trans., . vol. 22 , pp. $257-261 ., 3$ pls., 1909

Describes the discovery and occurrence of dinosaurian plates in western Kansas.

1102. A new trachodon from the Laramie beds of Converse County, Wyoming.Abstract: Science, new ser., vol. 29, pp. 753-754, May 7, 1909.

Sterrett, Douglas B.

1103. Mica deposits of South Dakota.-U. S. Geol. Survey, Bull. 380, pp. 382397, 4 figs., 1909.

Describes the location and general geology, the occurrence, and the mining of mica deposits in the vicinity of Custer, S. Dak., and explains the origin of the pegmatite.

Mineral resources of the United States, 1908: Mica; monazite and zircon; precious stones.-See no. 1170.

Monazite and monazite mining in the Carolinas.-See Pratt and Sterrett, no. 968 .

Stevens, Blamey.

-1104. The laws of fissures.-Am. Inst. Min. Eng., Bull., no. 32, pp. 722-739, 5 figs., August, 1909.

1105. Prince William Sound, Alaska; its geology and mineralogy.-Northwest Min. Jour., vol. 8, no. 1, pp. 3-6, 4 figs., September, 1.909. 
Stevenson, John James.

1106. Darwin and geology.-Pop. Sci. Monthly, vol. 74, pp. 349-354, April, 1909. 1107. Memoir of James Merrill Safford [1822-1907]:-Geol. Soc. America, Bull., vol. 19, pp. 522-527, 1 pl. (port.), 1909.

A sketch of his life and a list of his writings.

Stewart, C. A.

1108. The definition of marl.-Econ. Geology, vol. 4, no. 5, pp. 485-489, 1909.

Stieglitz, Julius.

1109. The relations of equilibrium between the carbon dioxide of the atmosphere and the calcium sulphate, calcium carbonate, and calcium bicarbonate of water solutions in contact with it. In The tidal and other problems, published by the Carnegie Institution of Washington, pp. 233-264, 1909.

Stoek, H. H.

1110. Coal fields of West Virginia.-Mines and Minerals, vol. 29, pp. 219-222, 283-287, 303-307, 6 figs., 1909.

1111. Marquette Range caving method.-Mines and Minerals, vol. 30, pp. 193200, 24 figs., November, 1909.

Includes notes on the geology, occurrence, and character of the iron ores of the Marquette Range, Michigan.

1112. Upper Potomac coal-fields.-Mines and Minerals, vol. 30, pp. 201-204, 6 figs., November, 1909.

1113. Coal fields of central West Virginia.-Mines and Minerals, vol. 30, pp. 188192, 7 figs., October, 1909.

Stone, C. A.

1114. Milling and mining Florida phosphates.-Eng. and Min. Jour., vol. 87, pp. 490-492, 11 figs., March 6, 1909.

Stone, Ralph W.

1115. Coal near the Crazy Mountains, Montana.-U. S. Geol. Survey, Bull. 341, pp. 78-91, 1 pl. (map), 1909.

Describes the geography, the general geology, and the structure of the area examined, the occurrence, character, and relations of the coal beds, and the quality of the coal.

Storms, William H.

1116. Geology of the Yellow Aster mine, Kern County, California.-Eng. and Min. Jour.; vol. 87, pp. 1277-1280, 3 figs., June 26, 1909.

1117. Great gold belt in Amador County, California.-Min. World, vol. 31, pp. 263-266, 4 figs., July 31, 1909.

1118. Consolidation of Mother Lode mines [California].-Min. and Sci. Press, vol. 99, pp. 597-598, 2 figs., October 30, 1909.

Includes notes on the local geology.

Stose, George W.

1119. Description of the Mercersburg-Chambersburg district, Pennsylvania.U. S. Geol. Survey, Geol. Atlas U. S., Mercersburg-Chambersburg folio (no. 170), library edition, 19 pp., 8 pls. (maps, sections, and illustrations sheets), 5 figs., 1909; field edition, 144 pp., 6 folded maps, 10 pls., 4 figs., 1910.

Describes the topographic features, the general geology, the occurrence, character, and relations of pre-Cambrian volcanic rocks, and of Cambrian. Ordovician, Silurian, and Devonian formations, the geologic structure, the geologic history, and the economic resources.

Stow, Audley H.

1120. Seismic disturbances and coal-mine explosions.-Eng. and Min. Jour., vol. 88, pp. 449-450, September 4, 1909. 
Stutzer, 0 .

1121. Die Kontaktmetamorphen Kupfererzlagerstätten von White Horse in Yukon, Canada.-Zeitschr. prakt. Geologie, Jg. 17, Heft 3, pp. 116-121, 1 fig., March, 1909.

Describes the contact-metamorphic copper-ore deposits of Whitehorse, Yukon Territory.

Surr, Gordon.

1122. Tungsten deposits and surface enrichment.-Min. World, vol. 30, pp. 1920, January 2, 1909.

1123. Distribution of metals and minerals in ore shoots.-Min. World, vol. 30; pp: 385-386, February 27, 1909.

1124. The association of ores and country rock.-Min. World, vol. 30, pp. 471-473, March 13, 1909.

1125. Granites.-Min. and Sci. Press, vol. 99, pp. 712-714, 1 fig., November 27, 1909.

Describes composition, characters, probable origin, etc., of granite.

Swartz, Charles K.

1126. Proposed classification of crystals based on the recognition of seven fundamental types of symmetry.-Geol. Soc. America, Bull., vol. 20, pp. 369-398, 2 pls., 28 figs., December, 1909. Abstract: Science, new ser., vol. 29, p. 631, April 16, 1909.

1127. Recurrence of the Tropidoleptus fauna and the geographic range of certain species in the Chemung of Maryland.-Abstract: Science, new ser., vol. 29, p. 635, April 16, 1909.

Symons, Brenton.

1128. Mineral resources of Newfoundland.-Min. Jour., London, vol. 87, pp. 167169, October 30, 1909.

Taff, Joseph A.

1129. The Sheridan coal field, Wyoming.-U. S. Geol. Survey, Bull. 341, pp. 123-150, 1 pl. (map), 1 fig., 1910.

Describes briefly the general features of the field and the stratigraphy of the coal-bearing rocks, and in more detail the occurrence, character, and mining of the coals.

1130. Grahamite deposits of southeastern Oklahoma.-U. S. Geol. Survey, Bull. 380, pp. 286-297, 1 fig., 1909.

1131. Ice-borne bowlder deposits in mid-Carboniferous marine shales.-Abstract: Science, new ser., vol. 29, p. 637, April 16, 1909.

Mineral resources of the United States, 1908: Asphalt, related bitumens, and bituminous rock.-See no. 1170.

Taff, J. A., and Reed, W. J.

1132. The Madill oil pool, Oklahoma.-U. S. Geol. Survey, Bull. 381-D (advance chapter), pp. 32-41, 1 pl. (map), 1 fig., 1909.

Describes the stratigraphy and the structure of the field, and the physical properties, occurrence development, and source of the oil.

Tallman, Clay.

1133. The Bullfrog district [Nevada].-Am. Min. Cong., 12th Ann. Sess., Rept. of Proc., pp. 428-437, 1909.

Includes an account of the geology of the district.

Tarr, R. P.

1134. The coal resources of Washington.-Mines and Minerals, vol. 30, pp. 17-19, 108-110, 135-138, 311-314, 12 figs., 1907. 
Tarr, Ralph S.

1135. The physiographic history of Watkins Glen, New York.-11th Ann. Rept., 1906, of the Am. Scenic and Historic Preservation Soc., Albany, 1906, pp. 113-141, 2 pls. (in Documents of the Assembly of the State of New York, 129th sess., 1906, vol. 12, no. 74).

1136. The Yakutat Bay region, Alaska; physiography and glacial geology.U. S. Geol. Survey, Prof. Paper 64, pp. 11-144, 36 pls., 10 figs., 1909.

Description of the Watkins Glen-Catatonk district, New York.-See Williams, Tarr, and Kindle, no. 1255.

Tarr, Ralph S., and Butler, Bert S.

1137. The Yakutat Bay region, Alaska.-U. S. Geol. Survey, Prof. Paper 64, 183 pp., 37 pls., 10 figs., 1909.

1138. The Yakutat Bay region, Alaska; areal geology.-U. S. Geol. Survey, Prof. Paper 64, pp. 145-170, 1 pl. (map), 1909.

Taylor, Arthur E.

1139. Indiana peat, its origin and value.-Am. Peat Soc., Jour., vol. 2, no. 1, pp. 30-33, no. 2, pp. 64-67, 1909.

Taylor, Frank Bursley.

1140. Field work on the Pleistocene deposits of southwestern Ontario.-Canada, Geol. Survey, Summ. Rept., 1908, pp. 103-111, 1909.

1141. The bearing of the Tertiary mountain belt upon the origin of the earth's plan.-Abstract: Science, new ser., vol. 29, pp. 624-625, April 16, 1909.

Tays, E. A. H.

1142. Mining in northern Sinaloa, Mexico.-Min. and Sci. Press, vol. 99, pp. 120121, July 24, 1909.

Includes notes on the geology of the region.

1143. San José de Gracia, a great Mexican gold camp.-Eng. and Min. Jour., vol. 88, pp. 640-645, 5 figs., October 2, 1909.

Includes notes on the local geology and the occurrence of the gold ores in the San Jose de Gracia district in the State of Sinaloa, Mexico.

Thomas, H. H., and MacAlister, D. A.

1144. The geology of ore deposits. London, Edward Arnold, 1909. 416 pp., 65 figs.

Thomas, Kirby.

1145. District of El Chico, State of Hidalgo, Mexico.-Mexican Min. Jour., vol. 8, no. 1, pp. 15-17, 2 figs., January, 1909.

Includes a short account of the local geology and the occurrence of gold and silver ores.

Tillotson, E. W.

Orthoklaszwillinge von ungewöhnlicher Ausbildung.-See Ford and Tillotson.

Todd, James E.

1146. Description of the Aberdeen-Redfield district, South Dakota.-U. S. Geol. Survey, Geol. Atlas U. S., Aberdeen-Redfield folio (no: 165), library edition, 13 pp., field edition, 99 pp., 12 pls. (maps), 14 figs., 1909.

Describes the geography, the general geology, the occurrence and relations of pre-Cambrian and Cretaceous strata and Quaternary deposits, the geologic history, and the economic resources, particularly the underground waters.

1147. Drainage of the Kansas ice sheet.-Kansas Acad. Sci., Trans., vol. 22, pp. 107-112, 1909.

Discusses the probable margin of the Kansas ice sheet in the State of Kansas, the line of the master drainage stream, and the extent of erosion in Pleistocene and more recent times.

56693ํ-Bull. $444-10-7$. 
Tolman, C. F.

1148. The geology of the vicinity of the Tumamoc Hills, Arizona.-In Spalding, Distribution and Movements of Desert Plants (Carnegie Inst., Washington, Publ. no. 113), pp. 67-82, 3 pls. (incl. maps), 1 fig., 1909.

1149. Erosion and deposition in the southern Arizona bolson region.-Jour. Geology, vol. 17, no. 2, pp. 136-163, 3 figs., 1909.

1150. The southern Arizona copper fields.-Min. and Sci. Press, vol. 99, pp. 356360, 390-393, 9 figs., September, 1909.

Describes the geology, and the occurrence and character of the copper ores.

1151. Disseminated chalcocite deposits at Ray, Arizona.-Min. and Sci. Press., vol. 99, pp. 622-624, 3 figs., November 6, 1909.

Describes the geologic relations, character, and occurrence of the copper ores.

1152. The Miami-Inspiration ore zone [Globe district, Arizona].-Min. and Sci. Press, vol. 99, pp. 646-658, 7 figs., November 13, 1909.

Describes the general geology of the district, and the occurrence, character, geologic relations, and genesis of the copper-ore deposits.

1153. Copper deposits of Silverbell, Arizona.-Min. and Sci. Press, vol. 99, pp. 710-712, 4 figs., November 27, 1909.

Describes the geology of the district, and the relations and characters of the copper-ore bodies.

True, Frederick W.

1154. A further account of the fossil sea lion Pontolis magnus, from the Miocene of Oregon.-U. S. Geol. Survey, Prof. Paper 59, pp. 143-148, 3 pls., 1909.

Truesdell, William H.

1155. Ray copper district, Arizona.-Min. and Sci. Press, vol. 98, pp. 794-797, 3 figs., June 5, 1909.

Describes the geology of the district, and the occurrence and character of the copper ores.

Turner, H. W.

1156. Contribution to the geology of the Silver Peak quadrangle, Nevada.-Geol. Soc. America, Bull., vol. 20, pp. 223-264, 4 pls., 1 fig., 1909.

Describes the geographic features, the occurrence, relations, and petrologic characters of pre-Cambrian, Cambrian, Ordovician, Tertiary, and Quaternary deposits, and of igneous and volcanic rocks, and structural features.

1157. Mining on the Mother Lode [California].-Min. and Sci. Press, vol. 98, pp. 40-41, 2 figs., January 2, 1909.

Includes notes on the local geology and the occurrence of the gold ores.

Twenhofel, W. H.

1158. The Silurian section at Arisaig, Nova Scotia. With a correlation note by Charles Schuchert.-Am. Jour. Sci., 4th ser., vol. 28, pp. 143-164, August, 1909.

Reviews previous work on the section describes the location, structure, petrology, mode of deposition, and subdivisions, and gives a detailed account of the various horizons, with lists of fossils.

Twitchell, M. W.

The geological distribution of the Mesozoic and Cenozoic Echinodermata of the United States.-See Clark and Twitchell, no. 238.

Tyrrell, J. B.

1159. Mineral veins in the Montreal district [Ontario].-Canadian Min. Jour., vol. 30, pp. 149-150, March 1, 1909. 
Tyssowski, John.

1160. Gypsum on Cape Breton Island, Nova Scotia.-Eng. and Min. Jour., 1 l. 88, pp. 569-570, 1. fig., September 18, 1909.

Udden, Johan August.

1161. Geological classification of the waters of Illinois.-Illinois State Geol. Survey, Bull. no. 10, pp. 8-21, 1 fig., 1909.

Discusses the occurrence of underground waters with respect to their geologic horizon.

Udden, Jon Andreas.

1162. Coal deposits and possible oil field near Duquoin, Illinois.-Illinois State Geol. Survey, Bull. no. 14, pp. 254-262, 1909.

Describes the stratigraphy and the coal beds, and the structure, pointing out the possible occurrence of oil.

1163. Coal deposits and oil field near Duquoin, Illinois.-Min. World, vol. 30 pp. 487-489, 1 fig., March 13, 1909.

Describes the stratigraphy and geologic structure of the region, and the occurrence, altitude, and character of the coal beds.

Uhlig, Tohannes.

1164. Untersuchung einiger Gesteine aus dem nordöstlichsten Labrador.-Ver. Erdk., Dresden, Mitt., Heft 8, pp. 230-236, 1909.

Describes rocks collected in northeastern Labrador (see Hantzsch, no. 508).

Ulrich, Edward Oscar.

1165. Ordovician paleogeography.-Abstract: Science, new ser., vol. 29, pp. 199200, January 29, 1909.

Discusses the criteria to be used in paleogeography.

1166. Revision of the Paleozoic systems in North America.-Abstract: Science, new ser., vol. 29, p. 630, April 16, 1909.

1167. Paleozoic erosion channels.-Abstract: Science, new ser., vol. 30, pp. 973974, December 31, 1909.

Gives a classification of erosion channels and describes examples from Ordovician and later Paleozoic deposits.

\section{United States Geological Survey.}

1168. The publications of the United States Geological Survey. Washington, 1909. $86 \mathrm{pp}$.

1169. Contributions to economic geology, 1908. Part I. Metals and nonmetals, except fuels.-U. S. Geol. Survey, Bull. 380, 406 pp., 2 pls., 32 figs., 1909.

The papers in this bulletin have been entered under the individual authors. Interspersed are lists of the Survey publications on various economic products.

1170. Mineral resources of the United States. Calendar year, 1908. Part I. Metallic products, $816 \mathrm{pp}$., 2 pls. (maps, in pocket), 3 figs., 1909. Part II. Nonmetallic products, 899 pp., 1 pl. (map, in pocket), 6 figs., 1909.

Contains the following papers, mainly statistical in character, relating to the production, condition of the industry, etc., but also in some cases including notes on the geology and occurrence of the products treated:

PART I.

Summary of mineral production in the United States in 1908, compiled by W. T. Thom, pp. 7-59.

Iron ores, pig iron, and steel, by E. C. Harder, pp. 61-134.

Manganese ores, by E. C. Harder, pp. 135-156.

Gold and silver, by .Waldemar Lindgren and H. D. McCaskey, pp. 157-183.

Copper, by B. S. Butler, pp. 185-226.

Lead, by C. E. Siebenthal, pp. 227-243. 


\section{United States Geological Survey-Continued.}

Zinc, by C. E. Siebenthal, pp. 245-273.

Gold, silver, copper, lead, and zine in the United States, pp. 275-276.

Gold, silver, copper, lead, and zinc in the Western States, pp. 277-586.

Silver, copper, lead, and zinc in the Central States, pp. 587-643.

Gold, silver, copper, lead, and zinc in the Eastern States, by H. D. McCaskey, pp. 645-681.

Quicksilver, by H. D. McCaskey, pp. 683-695.

Bauxite and aluminum, by W. C. Phalen, pp. 697-708.

Antimony, by Frank L. Hess, pp. 709-711.

Bismuth, by Frank L. Hess, pp. 713-714.

Selenium, by Frank L. Hess, pp. 715-717.

Tellurium, by Frank $\mathrm{C}$. Hess, pp. 719-720.

Tungsten, nickel, cobalt, vanadium, etc., by Frank L. Hess, pp. 721-749.

Chromic iron ore, by E. C. Harder, pp. 751-770.

Tin, by Frank I. Hess, pp. 771-779.

Platinum, by David T. Day, pp. 781-791.

Cadmium, by C. E. Siebenthal, pp. 793-803.

\section{PART II.}

FUELS.

Coal, by E. W. Parker, pp. 5-211.

Coal, briquetting, by E. W. Parker, pp. 213-221.

Coke, by E. W. Parker, pp. 223-283.

Gas, coke, tar, and ammonia, by E. W. Parker, pp. 285-316.

Natural gas, by B. Hill, pp. 317-344.

Petroleum, by David T. Day, pp. 345-440.

\section{STRUCTURAL MATERIALS.}

Cement industry in the United States in 19n8, by E. C. Eckel, pp. 441-453. Clay-working industries, by Jefferson Middleton, pp. 455-504.

Glass sand, other sand, and gravel, by A. T. Coons, pp. 505-510.

Lime, by A. T. Coons, pp. 511-515.

Sand-lime brick, pp. 517-519.

Slate, by A. T. Coons, pp. 521-532.

Stone, by $A$. T. Coons, pp. 533-579.

\section{ABRASIVES.}

Abrasive materials, by W. C. Phalen, pp. 581-598.

CHEMiCal MATERIALS.

Arsenic, by F. i. Hess, pp. 599-601.

Borax, by C. C. Yale, pp. 603-605.

Fluorspar and cryolite, by E. F. Burchard, pp. 607-620.

Gypsum, by E. F. Burchard, pp. 621-628.

Phosphate rock, by F. B. Van Horn, pp. 629-642.

Salt and bromine, by W. C. Phalen, pp. 643-657.

Sulphur and pyrite, by W. C. Phalen, pp. 659-668.

\section{PIGMENTS.}

Barytes and strontium, by E. F. Burchard, pp. 669-673.

Mineral paints, by E. F. Burchard, pp. 675-696.

\section{MISCELLANEOUS.}

Asbestos, by J. S. Diller, pp. 697-706.

Asphalt, related bitumens, and bituminous rock, by J. A. Taff, pp. 707-715.

Graphite, by E. S. Bastin, pp. 717-738.

Magnesite, by C. G. Yale, pp. 739-741.

Mica, by D. B. Sterrett, pp. 743-754.

Mineral waters, by S. Sanford, pp. 755-790.

Monazite and zircon, by D. B. Sterrett, pp. 791-794.

Peat, by Charles $A$. Davis, pp. 795-804.

Precious stones, by D. B. Sterrett, pp. 805-859.

Quartz and feldspar, by E. S. Bastin, pp. 861-868.

Talc and soapstone, by J. S. Diller, pp. 869-878. 
Upham, Warren.

1171. Glacial and modified drift of the Mississippi Valley from Lake Itasca to Lake Pepin.-Minnesota Acad. Sci., Bull., vol. 4, no. 2, pp. 299-305, 2 pls., 1906.

1172. The glacial Lake Agassiz.-Abstract: Canadian Min. Jour., vol. 30, p. 646, November 1, 1909.

Urbina, Fernando.

1173. Algunas observaciones acerca de la geografia fisica del Estado de Yucatan.Soc. Geol. Mexicana, Bol., t. 5, pp. 91-101, 11 pls., 1909.

Describes physical features of the State of Yucatan, Mexico. Includes notes on the geology.

1174. Notas sobre la caverna de Cacahuamilpa, Distrito de Alarcon, Estado de Guerrero.-Soc. Geol. Mexicana, Bol., t. 5, pp. 11-12, 151-155, 3 pls., 1909 .

Describes a cavern situated near Cacahuamilpa, District of Alarcon, State of Guerrero, Mexico.

1175. Nota acerca de unos supuestos yacimientos de cobre y de yeso en el partido . de Champoton (Estado de Campeche).-Soc. Geol. Mexicana, Bol., t. 6, pp. viii, 15-16, 1 pl., 1909.

$A$ brief note regarding supposed deposits of copper and of gypsum near Champoton, State of Campeche, Mexico.

Valiquette, J. H.

1176. Report on an exploration journey to Shining Mountain in the Labrador Peninsula.-Quebec, Dept. of Colonization, Mines, and Fisheries, Mining Operations, 1908, pp. 32-49, 7 pls., 1909.

Includes an account of the geology and mineral resources of the region visited.

Van Hise, Charles Richard.

1177. Principles of classification and correlation of the pre-Cambrian rocks.Jour. Geology, vol. 17, no. 2, pp. 97-104, 1909.

Van Hise, Charles Richard, and Leith, Charles Kenneth.

1178. Pre-Cambrian geology of North America.-U. S. Geol. Survey, Bull. 360, 939 pp., 2 maps, 1909.

Gives a general account of the pre-Cambrian rocks of North America and a summary of the literature relating to them, and a detailed account of their occurrence, relations, and characters in the several areas in which they are found.

Van Horn, F. B.

1179. The phosphate deposits of the United States.-U. S. Geol. Survey, Bull. 394, pp. 157-171, 1909. Rept. Nat. Conservation Comm. (60th Cong., 2d sess., Sen. Doc. no. 676), vol. 3, pp. 558-570, 1909. Abstract: Min. and Sci. Press, vol. 99, pp. 88-90, 2 figs., July 17, 1909.

Mineral resources of the United States, 1908: Phosphate rock.-See no. 1170.

Van Horn, Frank R.

1180. A recent landslide in a shale bank near Cleveland accompanied by buckling.-Abstract: Science, new ser., vol. 29, p. 626, April 16, 1909.

Van Ingen, Gilbert.

1181. The stratigraphic position of the oolitic iron ore at Bloomsburg, $\mathrm{Pa}$.Abstract: Science, new ser., vol. 29, p. 830, May 21, 1909.

The so-called Clinton ores are considered to be of Salina age. 
Vaughan, T. Wayland.

1182. Geology of the Florida Keys and the marine bottom deposits and recent corals of southern Florida.-Carnegie Inst. of Washington, Yearbook no. 7,1908 , pp. 131-138, 1909.

Gives notes upon the character of the deposits forming the Keys.

1183. The geologic work of mangroves in southern Florida.-Smithsonian Misc. Coll., vol. 52 (Quart. Issue, vol. 5, pt. 4), pp. 461-464, 7 pls., 2 figs., 1909.

Veatch, Otto.

1184. Second report on the clay deposits of Georgia.-Georgia, Geol. Survey, ,Bull. no. 18, 453 pp., 32 pls., 15 figs., 3 maps, 1909.

Villarello, Juan D.

1185. Hidrologia subterranea de los alrededores de Montenegro (Estado de Queretaro).-Soc. Geol. Mexicana, Bol., t. 5, pp. 37-65, 1 pì., 1909.

Describes the physiographic features, the geology, and the underground waters in the vicinity of Montenegro, State of Queretaro, Mexico.

1186. Los granitos de las canteras "Leahy," "Red Stone," (New Hampshire) y "Bienvenue," (Maine) E. U. A.-Soc. Geol. Mexicana, Bol., t. 6, pp. ixxi, 37-66, 18 pls., 1909.

Describes the granites quarried in the Leahy and Red Stone quarries near Conway, New Hampshire, and the Bienvenue quarry on Deer Island, Maine.

1187. Hidrologia subterranea de los alrededores de Patzcuaro, Michoacan, Mexico.Mexico, Inst. Geol., Parerg., t. 2, no. 9, pp. 341-362, 1 fig., 1909.

Describes the underground water resources of the vicinity of Patzcuaro, Michoacan. Includes a brief account of the geology of the region.

1188. El pozo de petroleo de Dos Bocas.-Mexico, Inst. Geol., Parerg., t. 3, no. 1, pp. 5-112, 27 pls., 1909.

Describes the petroleum well of Dos Bocas, State of Vera Cruz, Mexico.

1189. Some petroleum-bearing regions of Mexico.-Min. Jour., London, vol. 85, p. 609, May 15, 1909.

1190. Principal petroleum-bearing regions of Mexico.-Min. World, vol. 31, pp. 28-31, July 3, 1909.

1191. The mode of filling of some Mexican ore deposits.-Min. Jour., London, vol. 87, pp. 169-170, 208-209, October 30 and November 6, 1909.

Villarello, J. D., Flores, T., and Robles, R.

1192. Geologic study of the Sierra of Guanajuato.-Eng. and Min. Jour., vol. 88. pp. 672-677, 4 figs., October 2, 1909.

Includes an account of the ore deposits of Guanajuato district, in the State of Guanajuato, Mexico.

Villars, J. R.

1193. Spheroidal weathering of dikes.-Min. and Sci. Press, vol. 98, p. 443, 1 fig., March 27, 1909.

Wade, W. Rogers.

1194. The gem-bearing pegmatites of western Maine.-Eng. and Min. Jour., vol. 87, pp. 1127-1129, June 5, 1909.

Describes the occurrence and geologic relations of tourmaline.

Warlsworth, M. Edward.

1195. Crystallography, an elementary manual for the laboratory. Philadelphia, John Joseph McVey, 1909. 299 pp., 25 pls.

Wainewright, Wilfrid $B$.

1196. Borate deposits of California.-Manchester Geol. and Min. Soc., Trans., vol. 31, pt. 4, pp. 60-66, 1909; Inst. Min. Eng., Trans., vol. 37, pt. 1, pp. 156-162, 1909. 
Waitz, Pablo.

1197. Principios de clasificacion y comparacion de rocas macizas (igneas).-Soc.

Geol. Mexicana, Bol., t. 6, pp. xi-xii, 17-36, 3 pls., 1909.

Discusses the classification of igneous rocks.

Walcott, Charles D.

1198. Evolution of early Paleozoic faunas in relation to their environment.-Jour. Geology, vol. 17, no. 3, pp. 193-202, 1909.

Walker, T. L.

1199. Report on the tungsten ores of Canada.-Canada, Dept. Mines, Mines Branch, 56 pp., 10 pls., 1 fig., 1909.

1200. Tungsten ores in Canada.-Min. World, vol. 30, p. 747, 2 figs., April 17, 1909.

Ward, Freeman.

1201. On the Lighthouse granite near New Haven, Connecticut.-Am. Jour. Sci., 4th ser., vol. 28, pp. 131-142, 3 figs., August, 1909.

Describes the character and extent of the formation, and its petrographic characters and structure.

Calamine crystals from the Organ Mountains, Donna Anna County, New Mexico.-See Ford and Ward, no. 419.

Waring, Gerald A.

1202. Geology and water resources of the Harney Basin region, Oregon.-U. S. Geol. Survey, Water-Supply Paper 231, 93 pp., 5 pls., 1909.

Warren, C. H.

1203. Note on the occurrence of an interesting pegmatite in the granite of Quincy, Massachusetts.-Am. Jour. Sci., 4th ser., vol. 28, pp. 449-452, November, 1909.

Washburne, Chester W.

1204. Coal fields of the northeast side of the Bighorn Basin, Wyoming, and of Bridger, Montana.-U. S. Geol. Survey, Bull. 341, pp. 165-199, 1 pl. (map), 1910.

Describes the general features of the field, the stratigraphy of the coal beds, and the distribution, relations, and character of the coals.

1205. Development in the Boulder oil field, Colorado.-U. S. Geol. Survey, Bull. 381-D (advance chapter), pp. 42-44, 1909.

1206. The Florence oil field, Colorado.-U. S. Geol. Survey, Bull. 381-D (advance chapter), pp. 45-72, 2 pls., 2 figs., 1909.

Describes the general geology, stratigraphy, and structure of the field, the mode of occurrence and character of the oil, and the development and production of the field.

1207. Some observations on Rocky Mountain faults.-Abstract: Science, new ser., vol. 29, pp. 555-556, April 2, 1909.

Washington, Henry S.

The distribution of the elements in igneous rocks.-Am. Inst. Min. Eng., Trans., vol. 39 , pp. 735-764, 1909 . See no. 1111 of the bibliography for 1908, U. S. Geol.Survey, Bull. 409, p. 87.

Diamonds in Arkansas.-See Kunż and Washington.

Watson, C. B.

1208. Prehistoric Siskiyou Island and Marble Halls of Oregon. Copyright January 4,1909 , by C. B. Watson. $147 \mathrm{pp}$.

Watson, Thomas Leonard.

1209. Annual report on the mineral production of Virginia during the calendar year 1908.-Virginia Geol. Survey, Bull. no. I-A, 141 pp., 1 pl. (map), 25 figs., 1909. 
Watson, Thomas Leonard-Continued.

1210. The manganese ore deposits of Georgia.-Econ. Geology, vol. 4, no. 1, pp. 46-55, 1909. Min. World, vol. 30, pp. 643-644, April 3, 1909.

1211. Petrology of the South Carolina granites.-Jour. Geology, vol. 17, no. 8, pp. 730-751, 5 figs., 1909.

Weaver, Charles E.

1212. Stratigraphy and paleontology of the San Pablo formation in middle California.-California, Univ., Dept. Geology, Bull., vol. 5, no. 16, pp. 243-269, 1909.

Reviews previous work on the San Pablo formation, describes its geographic distribution, stratigraphic relations, and correlation, and gives a list of species occurring in it by horizons. Considers the San Pablo to be lower Pliocene.

Weeks, Fred B., and Nickles, John M.

1213. Bibliography of North American geology for 1906 and 1907, with subject index.-U. S. Geol. Survey, Bull. 372, 317 pp., 1909.

Wegemann, Carroll H.

1214. Some notes on river development in the vicinity of Danville, Illinois.-Univ. Illinois Bull., vol. 6, no. 17, The University Studies, vol. 3, no. 2, pp. 21-42, 3 pls., January, 1909.

Gives a detailed account of geologic and physiographic features of the vicinity of Danville, III., and discusses the development of the drainage of the area.

1215. Notes on the coals of the Custer National Forest, Montana.-U. S. Geol. Survey, Bull. 381-A (advance chapter), pp. 104-110, 1 pl. (map and sections), 1909.

Describes the topography and geology of the field, and the distribution and character of the coal beds.

Welch, R. Kemp.

1216. The placer mining industry of North Carolina.-Min. World, vol. 30, pp. 965-967, 8 figs., May 22, 1909.

Includes notes upon the occurrence and source of placer gold in North Carolina.

Weld, C. M.

1217. The residual brown iron ores of Cuba.-Am. Inst. Min. Eng., Bull., no. 32, pp. 749-762, 3 figs., August, 1909.

Weller, Stuart.

1218. Kinderhook faunal studies. $V$, The fauna of the Fern Glen formation.Geol. Soc. America, Bull., vol. 20, pp. 265-332, 6 pls., July, 1909.

Describes fossils from the Fern Glen formation in Missouri and Illinois, and discusses the correlation of the Fern Glen formation and its fauna.

1219. Correlation of the middle and upper Devonian and the Mississippian faunas of North America.-Jour. Geology, vol. 17, no. 3, pp. 257-285, 1909.

1220. Description of a Permian crinoid fauna from Texas.-Jour. Geology, vol. 17 , no. 7, pp. 623-635, 1 pl.,. 1909.

1221. The fauna of the Fern Glen formation.-Abstract: Science, new ser., vol. 29, p. 636, April 16, 1909.

West, H. E.

1222. Impressions of a new Ontario camp, Gowganda.-Eng. and Min. Jour., vol. 87, pp. 900-902, May 1, 1909.

Includes notes on the occurrence and geologic relations of the silver ores in the Gowganda district.

1223. Features of a vein formation in Nicaragua.-Eng. and Min. Jour., vol. 87, pp. 1130-1133, 4 figs., June 5, 1909.

Describes the local geology and the occurrence and geologic relations cf gold and silver bearing manganese deposits in the Matagalpa district of Nicaragua. 
Wheeler, H. A.

1224. Oil and gas in the St. Louis district.-Assoc. Eng. Soc., Jour., vol. 42, pp. 188-199, 2 figs., April, 1909.

Wheeler, H. E.

1225. A week at Claiborne, Alabama.-Nautilus, vol. 22, pp. 97-98, February, 1909.

Includes notes on the occurrence of fossils in the Eocene deposits of this locality.

Wheeler, Joseph $\mathrm{T}$.

1226. The zonal-belt hypothesis; a new explanation of the cause of the ice ages.

Philadelphia, J. B. Lippincott Company, 1908, 401 pp.

Wherry, Edgar T.

1227. A new occurrence of carnotite.-Abstract: Science, new ser., vol. 29, p. 751, May 7, 1909.

1228. Second annual spring conference of the geologists of the northeastern United States.-Science, new ser., vol. 30, pp. 414-416, September 24, 1909.

Gives an account of the meeting and abstracts of the papers presented.

1229. The early Paleozoic of the Lehigh Valley district, Pennsylvania.-Abstract: Science, new ser., vol. 30, p. 416, September 24; 1909.

Characterizes the formations of Cambrian and Ordovician age.

White, David.

1230. The effect of oxygen in coal.-U. S. Geol. Survey, Bull. 382, 74 pp., 3 pls., 1909.

1231. The upper Paleozoic floras, their succession and range.--Jour. Geology, vol. 17, no. 4, pp. 320-341, 2 figs., 1909.

1232. Paleobotanical work in Illinois in 1908.-Illinois State Geol. Survey, Bull. no. 14, pp. 293-295, 1909.

Includes notes on the correlation of the coal beds.

1233. Occurrence of resin in Paleozoic coals.-Abstract: Science, new ser., vol. 29, p. 945, June 11, 1909.

1234. Graphic methods of representing the regional metamorphism of coals.Abstract: Science, new ser., vol. 30, p. 62, July 9, 1909.

White, Douglas.

1235. The zinc mines of southern Nevada. Am. Min. Cong., 12th Ann. Sess., Rept. of Proc., pp. 401-411, 1909.

Describes briefly the geologic occurrence of the zinc ores.

White, I. C.

1236. Shortage of coal in the northern Appalachian coal field.-Geol. Soc. America, Bull., vol. 20, pp. 333-340, 1909.

Discusses the distribution of workable beds, the method of deposition of the coal, and the duration of the field under present methods of mining and use.

1237. The barren zone of the northern Appalachian coal field and its relations to Pittsburg's industries. Address of Dr. I. C. White, state geologist of West Virginia, before the Am. Min. Congress, Pittsburg, Pennsylvania, on Friday, the 5th day of December, 1908. $20 \mathrm{pp}$. Also in Am. Min. Congress, 11th Ann. Sess., Papers and Addresses, pp. 166-176, 1909.

1238. West Virginia Geological Survey, Coal Report. Discussion of review by M. R. Campbell.-Econ. Geology, vol. 4, no. 3, pp. 261-262, 1909.

White, W. P.

Diopside and its relations to calcium and magnesium metasilicates.-See Allen and White, no. 20. 
Whiteaves, J. F.

1239. [Report on] paleontology and zoology.-Canada Geol. Survey, Summ. Rept., 1908, pp. 171-175, 1909.

1240. Notes on some fossils from the Cambro-Silurian and Silurian rocks of the Albany River drainage system in northwestern Ontario.-Canada, Geol. Survey, Report on a portion of Algoma and Thunder Bay districts, Ontario, by W. J. Wilson, pp. 34-41, 1909.

1241. Description of a new species of ammonite, of the genus Stepheoceras, from some rocks of presumably Jurassic age in the Nicola Valley, B. C.Ottawa Naturalist, vol. 23, no. 2, pp. 21-23, 1 pl., May, 1909.

Whitlock, H. P.

1242. Some parallel groupings of calcite crystals from the New Jersey trap region.New York State Mus., Bull., 133, pp. 217-221, 2 figs., 1909.

Whitney, Milton.

1243. Soils of the United States, based upon the work of the Bureau of Soils to January 1, 1908.-U. S. Dept. Agric., Bur. Soils, Bull. no. 55, 243 pp., 2 pls., 7 figs., 1909.

Whitney, Milton, and others.

1244. Field operations of the Bureau of Soils, 1907.-U. S. Dept. Agric., Bureau of Soils, Ninth Report, Washington, 1909. 1062 pp., 4 pls., 36 figs., and 35 soil maps (in separate case).

Contains soil surveys of the following areas:

Alabama, Butler County, pp. 437-465.

Marion County, pp. 381-400.

Talladega County, pp. 401-436.

Arkansas, Conway County, pp. 753-771.

California, Colusa area, pp. 927-972.

Redding area, pp. 973-999.

Siskiyou County, Butte Valley, pp. 1001-1014.

Florida, Jefferson County, pp. 345-379.

Idaho, Minidoka area, pp. 909-926.

Indiana, Marion County, pp. 793-812.

Louisiana, Winn Parish, pp. 557-589.

Maryland, Easton area, pp. 121-163.

Mississippi, Jasper County, pp. 525-556.

Oktibbeha County, pp. 467-502.

Prentiss County, pp. 503-523.

Nebraska, North Platte area, pp. 813-836.

New York, Dutchess County, pp. 31-79.

North Carolina, Edgecombe County, pp. 249-269.

Henderson County, pp. 227-247.

North Dakota, McKenzie area, pp. 859-879.

Morton area, pp. 837-858.

Pennsylvania, Johnston area, pp. 81-120.

South Carolina, Lee County, pp. 323-343.

Oconee County, pp. 271-298.

Sumter County, pp. 299-321.

South Dakota, Bellefourche area, pp. 881-906.

Tennessee, Giles County, pp. 773-791.

Texas, Bastrop County, pp. 663-704.

Brownsville area, pp. 705-732.

Cooper area, pp. 733-752.

Robertson County, pp. 591-640.

Wilson County, pp. 641-662.

Virginia, Montgomery County, pp. 193-225.

Washington, Bellingham area, pp. 1015-1049.

West Virginia, Middlebourne area, pp. 165-192.

Whytock, P. R.

1245. The Rawhide district, Nevada.-Min. World, vol. 31, p. 266, July 31, 1909.

Describes the occurrence of the gold ores. 
Wiard, Edward S.

1246. Ore dressing in the Cour d'Alene district, Idaho.-Eng. and Min. Jour., vol. 88, pp. 1055-1060, 7 figs., November 27, 1909.

. Includes notes on the geology of the region and the character and occurrence of the silverlead ores.

Wickham, H. F.

1247. New fossil Coleoptera from Florissant.-Am. Jour. Sci., 4th ser., vol. 28, pp. 126-130, August, 1909.

Wiechert, E.

1248. Our present knowledge of the earth.-Smithsonian Inst., Ann. Rept. for 1908, pp. 431-449, 1909.

Wieland, G. R.

1249. Revision of the Protostegidæ.-Am. Jour. Sci., 4th ser., vol. 27, pp. 101-130, 3 pls., 12 figs., February, 1909.

1250. A new armored saurian from the Niobrara.-Am. Jour. Sci., 4th ser., vol. 27, pp. 250-252, 10 figs., March, 1909.

Describes Hierosaurus sternbergii from the Niobrara chalk of western Kansas.

1251. The Williamsonias of the Mixteca Alta, Mexico.-Bot. Gazette, vol. 48, pp. 427-441, 10 figs., December, 1909.

Describes the occurrence of cycads of Triassic or Jurassic age in Oaxaca, Mexico, and gives notes upon the fossils.

Wilder, F. A.

1252. Fuel values of Iowa coals.-Iowa Geol. Survey, vol. 19, pp. 397-475, 8 pls., 1 fig., 1909.

Willard, Daniel E.

1253. Description of the Jamestown-Tower district, North Dakota.-U. S. Geol. Surveÿ, Geol. Atlas U. S:, Jamestown-Tower folio (no. 168), library edition, 10 pp., 9 pls. (maps), 6 figs., field edition, 76 pp., 9 folded maps, 2 pls., 4 figs., 1909 :

Describes the general features, the Cretaceous and Quaternary deposits, the geologic history, the water supply, and the soils.

\section{Williams, Henry S.}

1254. On the age of the Gaspé sandstone.-Abstract: Science, new ser., vol. 29, p. 635, April 16, 1909.

Williams, H. S., Tari, R. S., and Kindle, E. M.

1255. Description of the Watkins Glen-Catatonk district, New York.-U. S. Geol. Survey, Geol. Atlas U. S., Watkins Glen-Catatonk folio (no. 169), library edition, 33 pp., 8 pls. (maps and illustrations sheets), 13 figs., field edition, 242 pp., 6 folded maps, 24 pls., 13 figs., '1909.

Describes the topographic features, the occurrence, character, relations, faunal characteristics, boundaries, and correlations of Devonian formations, the occurrence and character of igneous rocks, geologic structures in the Devonian rocks, the Quaternary deposits, the geologic history and physiographic record, and the economic resources.

Willis, Bailey.

1256. Paleogeographic maps of North America.-Jour. Geology, vol. 17, pp. 203$208,253-256,286-288,342-343,403-405,406-407$, 408-409, 424-425, 426-428, 503-505, 506-508, 600-602, 15 figs. (paleogeographic maps), 1909.

Gives paleogeographic maps of North America in lower Cambrian, late middle and upper Cambrian, middle Ordovician, Silurian, Middle Devonian, Mississippian, Pennsylvanian, latest Paleozoic, Triassic, late Jurassic, Lower Cretaceous, Upper Cretaceous, Eocene-Oligocene, Miocene, and Quaternary time.

1257. [Report on symposium on correlation].-Science, new ser., vol. 29, pp. 748-750, May 7, 1909. 
Williston, Samuel W.

1258. The skull and extremities of Diplocaulus.-Kansas Acad. Sci., Trans., vol. 22, pp. 122-131, 6 pls., 1909.

1259. The faunal relations of the early vertebrates.-Jour. Geology, vol. 17, no. 5, pp. 389-402, 1909.

1260. New or little-known Permian vertebrates: Trematops, new gen.-Jour. Geology, vol. 17, no. 7, pp. 636-658, 7 figs., 1909.

1261. Discussion of paper by R. S. Lull, Dinosaur societies.-Abstract: Science, new ser., vol. 29, p. 194, January 29, 1909.

Wilson, Alfred W. G.

1262. Trap sheets of the Lake Nipigon basin [Ontario].-Geol. Soc. America, Bull., vol. 20, pp. 197-222, 4 figs., June, 1909.' Abstract: Science, new ser., vol. 2@, pp. 635-636, April 16, 1909 .

Presents and discusses evidence to determine whether the capping trap sheets are surface flows or intrusions.

1263. The region in the vicinity of Lake Nipigon, Thunder Bay district, Ontario.Canada, Geol. Survey, Summ. Rept., 1908, pp. 95-96, 1909.

Includes notes on the geology of the area examined.

Wilson, E. B.

1264. Geological nomenclature.-Min. Science, vol. 57, pp. 460-461, 2 figs., Máy 14, 1908.

Discusses the application of the terms dip, pitch, and hade.

1265. Boron.-Mines and Minerals, vol. 30, pp. 168-170, October, 1909.

Includes notes on the minerals containing boron and their occurrence.

Wilson, Morley E.

1266. Lake Opasatika and the Height of Land.-Canada, Geol. Survey, Summ. Rept., 1908, pp. 121-123, 1909.

Describes briefly the physiographic features, the general geology, and the occurrence and character of the formations of the area examined in the western part of the Province of Quebec, Canada.

Wilson, W. J.

1267. Geological reconnaissance of a portion of Algoma and Thunder Bay districts, Ontario.-Canada, Geol. Survey, 49 pp., 6 pls., 1909.

1268. Summary report dealing with the field work in connexion with the collection of paleontological material from the Devonian and lower Carboniferous of New Brunswick.-Canada, Geol. Survey, Summ. Rept., 1908, pp. 183$185,1909$.

Winchell, Alexander N.

Elements of optical mineralogy.-See Winchell and Winchell, no. 1273.

Winchell, Newton Horatio.

1269. Some features in the geology of northeastern Minnesota.-Abstract: Minne-: sota Acad. Sci., Bull., vol. 4, no. 2, p. 201, 1906 (Printed in full in the Amer. Geologist, July, 1897).

1270. Glacial lakes of St. Louis and Nemadji.-Abstract: Minnesota Acad. Sci., Bull., vol. 4, no. 2, p. 208, 1906.

1271. Deep wells as a source of water for Minneapolis.-Abstract: Minnesota Acad. Sci., Bull., vol. 4, no. 2, p. 266, 1906.

1272. A diamond drill core section of the Mesabi rocks.-Lake Superior Min. Inst., Proc., vol. 14, pp. 156-178, 1909.

Describes the megascopic characters of specimens taken from a drilling in the Mesabi Range, Minnesota. 
Winchell, N. H., and Winchell, Alexander N.

1273. Elements of optical mineralogy: an introduction to microscopic petrography, with description of all minerals whose optical elements are known and tables arranged for their determination microscopically. New York, B. Van Nostrand Company, 1909. 502 pp., 4 pls., 350 figs.

Winston, W. B.

1274. Arteaga district, Chihuahua, Mexico.-Min. and Sci. Press., vol. 98, pp. 829830, 4 figs., June 12, 1909.

Includes notes on the geologic occurrence of the gold ores.

\section{Wisconsin Geological and Natural History, Survey.}

1275. Sixth biennial report of the commissioners of the Geological and Natural History Survey covering the period from July 1, 1906, to June 30, 1908. Madison, Wisconsin, 1908. $45 \mathrm{pp}$.

An administrative report.

Wittich, Ernesto.

1276. Contribuciones a la geologia de la region meridional de la Baja California.Soc. Geol. Mexicana, t. 6, pp. xii-xiii, 5-14, 1 pl., 1909.

Describes the general features of the southern part of I.ower California, the occurrence, character, and relations of igneous rocks, and Tertiary, Quaternary, and recent deposits and the geologic structure.

Wolcott, G. E.

1277. Mining and milling at Rawhide, Nevada.-Eng. and Min. Jour., vol. 87, pp. 345-348, 7 figs., February 13, 1909.

Describes the local geology and the occurrence of gold ores.

Wolff, J. Fred.

1278. Open-pit iron mining on the Mesabi Range of northern Minnesota.-Mines ' and Minerals, vol. 29, pp. 291-293, 4 figs., February, 1909.

Includes notes on the geologic occurrence of the iron ores.

Wolff, John E.

1279. Notes on the Crazy Mountains, Montana.-Abstract: Geol. Soc. America, Bull., vol. 19, pp. 557-558, 1909.

Wood, Elvira.

1280. A critical summary of Troost's unpublished manuscript on the crinoids of Tennessee.-U. S. Nat. Mus., Bull. 64, 150 pp., 16 pls., 1 fig., 1909.

Wood, George McLane.

1281. Suggestions to authors of papers submitted for publication by the United States Geological Survey, with directions to typewriters.-U. S. Geol. Survey, 1909. $50 \mathrm{pp}$.

States the practice of the Survey in the preparation of its publications. Includes definitions of geologic terms.

Wood, H. O.

Crystallographic notes on minerals from Chester, Mass.-See Palache and Wood, no. 933 .

Wood, Katharine Hill.

Bibliography of North Carolina geology, mineralogy, and geography, with a list of maps.-See Laney and Wood, no. 736.

Woodman, J. Edmund.

1282. Report on the iron ore deposits of Nova Scotia (Part I).-Canada, Dept. Mines, Mines Branch, 226 pp., 63 pls., 1909. Canadian Min. Jour., - vol. 30, pp. 496-498, 550-556, 621-627, 6 figs., 1909. 
Woodruff, Elmer Grant.

1283. The Red Lodge coal field, Montana.-U. S. Geol. Survey, Bull. 341, pp. 921.07, 1 pl., 1 fig., 1909.

Describes the surface features, the stratigraphy and structure of the field, the occurrence and character of the coal beds, and the character of the coal.

1284. Coal fields of the southwest side of the Bighorn Basin, Wyoming.-U. S. Geol. Survey, Bull. 341, pp. 200-219, 1 pl. (map), 1909.

Describes the stratigraphy and structure of the field and the geologic occurrence, mining, and character of the coals.

1285. Sulphur deposits near Thermopolis, Wyo.-U. S. Geol. Survey, Bull. 380, pp. 373-380, 1 fig., 1909.

Describes the location, geologic relations and structure, and the occurrence and origin of the sulphur ore.

Woodward, A. Smith.

1286. Address of the president to the geological section of the British Association for the Advancement of Science.-Science, new ser., vol. 30, pp. 321-331, September 10, 1909.

Discusses evolution among the vertebrates and the problems which this study has raised.

Woodworth, Jay B.

1287. Report on the Harvard seismographic station.-Harvard Univ., Mus. Comp. Zool., Ann. Rept. of the Curator, 1908-09, pp. 28-32, 1 pl., 1909.

Woolsey, Lester H.

1288. The Bull Mountain coal field, Montana.-U. S. Geol. Survey, Bull. 341, pp. 62-77, 1 pl. (map), 1909.

Describes the general geology, the occurrence and character of the coal beds, the character of the coal, and the development.

Wright, C. T.

1289. The laboratories for physical geography in two California high schools.Jour. Geography, vol. 8, no. 1, pp. 10-14, 3 figs., September, 1909.

Wright, Charles W.

1290. Mining in southeastern Alaska.-U. S. Geol. Survey, Bull. 379, pp. 67-86, 2 pls., 1909.

Includes notes on the geology of 'Kasaan Peninsula and other districts of southeastern Mlaska.

Wright, Fred. Eugene.

1291. Über Enstatit und Klinoenstatit.-Zeitschr. Krystal. und Mineral., Bd. 46, Heft 6, pp. 599-600, 1909.

Gives optical measurements of clinoenstatite crystals and calls attention to distinctions between enstatite and clinoenstatite.

The binary systems of alumina with silica, lime, and magnesia; optical study.-See Shepherd and Rankin, no. 1056.

Wright, Fred. Eugene, and Larsen, Esper S.

1292. Quartz as a geologic thermometer.-Am. Jour. Sci., 4th ser., vol. 27, pp. 421'447, June, 1909. Abstract: Science, new ser., vol. 29, p. 556, April 2, 1909; p. 634, April 16, 1909.

Wright, George Frederick.

1293. Geological facts bearing on the place of the origin of the human race.Abstract: Science, new ser., vol. 29, p. 512, March 26, 1909. 
Wright, J. W.

1294. The Black Range mining district, New Mexico.-Min. World, vol. 31, pp. 979-981, 4 figs., November 13, 1909.

Includes notes on the local geology and the occurrence of the ores yielding gold, silver, and copper.

Yates, J. A.

1295. Study of certain features of the Lawrence shales.-Kansas Acad. Sci., Trans., vol. 22, pp. 117-121, 1909.

Yeandle, W. H.

1296. Notes on the effect of earthquakes on deep underground water circulation.Eng. and Min. Jour., vol. 88, p. 871, October 30, 1909.

\section{Young, George A.}

1297. A descriptive sketch of the geology and economic minerals of Canada.Canada, Geol. Survey, 151 pp., 82 pls., 2 maps, 1909. Abstract: Canadian Min. Jour., vol. 30, pp. 684-685, November 15, 1909.

1298. Summary report on a district near Bathurst, N. B., and on the reported occurrence of gold in the Tobique country, Victoria Co., N. B.-Canada, Geol. Survey, Summ. Rept., 1908, pp. 129-131, 1909.

Describes the general geology and the occurrence and relations of an iron-ore deposit, and gives general notes on the Tobique country.

Zalinski, Edward R.

1299. Amatrice, a new gem stone of Utah.-Eng. and Min. Jour., vol. 87, pp. 10381039, 2 figs., May 22, 1909.

Describes the gem material, and its geological occurrence in Tooele County, Utah.

1300. Some notes on pitchblende.-Salt Lake Min. Rev., vol. 11, no. 14, pp. 2527, 2 figs., October 30, 1909.

Zambonini, F.

1301. Über Enstatit und Klinoenstatit.-Zeitschr. Krystal. und Mineral., Bd. 46, Heft 6, pp. 601-602, 1.909.

A discussion in regard to the distinctions between enstatite and clinoenstatite.

Zehring, W. S.

1302. The Nevada-Douglas copper properties, Nevada.-Min. World, vol. 30, pp. 736-738, 2 figs., April 17, 1909.

Includes notes on the geology and occurrence of the copper ores.

\section{Anonymous.}

1303. Earthquakes and firedamp.-Mines and Minerals, vol. 30, pp. 252-253, November, 1909.

1304. Geologic note on Liberty Bell.-Min. and Sci. Press, vol. 98, p. 793, June 5, 1909.

Describes the geologic conditions and occurrence of the ores in the Liberty Bell mine, at Telluride, Colorado.

1305. Rutile deposits of Virginia.-Min. and Sci. Press, vol. 98, p. 896, June 26, 1909. 


\section{CLASSIFIED SCHEME OF SUBJECT HEADINGS.}

\section{GENERAL.}

Associations, meetings; Addresses; History; Philosophy; Biography; Bibliography; Educational; Text-books.

Classification; Nomenclature; Cartography; Technique; Fieldwork; Surveys; Borings.

Geochemistry; Chemical analyses (list); Atmosphere.

Miscellaneous.

\section{REGIONAL.}

The States of the Union, Alabama, etc.; the Provinces of Canada, Alberta, etc.; Greenland; Mexico; the countries of Central America; the West Indies, and the single islands; the Hawaiian Islands.

3. ECONOMIC.

Ore deposits, origin; Contact phenomena.

Gold; Placers; Black sands; Silver; Quicksilver; Nickel; Cobalt; Copper; Lead; Zinc; Iron; Magnetite; Manganese; Tin; Aluminum; Bauxite; Antimony; Bismuth; Tungsten; Wolframite; Vanadium; Uranium; Carnotite ores; Molybdenum; Molybdenite; Titanium; Rutile; Platinum; Monazite; Rare earths; Tantalum; Selenium; Tellurium; Zircon.

Coal; Anthracite; Coke; Peat; Lignite; Bituminous rock; Natural gas; Petroleum; Oil shales; Asphalt; Albertite; Gilsonite; Grahamite; Ozokerite.

Stone; Building stone; Granite; Bluestone; Limestone; Lime; Marble; Onyx; Sandstone; Clay; Kaolin; Bentonite; Fire clay; Ganister; Slate; Shale; Marl; Sand; Glass sand; Sand-lime brick; Gravel; Cement and cement materials; Concrete materials; Road materials; Trap; Steatite; Soapstone; Talc.

Precious stones; Diamonds; Sapphires; Turquoise; Tourmaline.

Abrasive materials; Corundum; Emery; Garnet; Diatomaceous earth; Tripoli; Volcanic ash; Millstones; Novaculite.

Asbestos; Feldspar; Mica; Quartz; Gypsum; Graphite; Fuller's earth; Infusorial earth; Magnesite; Mineral paint; Chromium; Chromite; Chromic iron ore; Fluorspar; Barite; Barytes; Strontium; Arsenic; Pyrite; Sulphur; Sulphate of soda; Cryolite; Phosphorus; Phosphate; Apatite; Glauconite; Borax; Bromine; Salt; Natron deposits.

\section{DYNAMIC AND STRUCTURAL.}

. Earth, genesis of; Earth, age of; Earth, interior of; Earth, temperature of.

Volcanoes; Earthquakes; Seismographs.

Isostasy; Orogeny; Changes of level.

Magmas; Intrusions; Dikes; Laccoliths; Metamorphism; Contact phenomena.

Deformation; Folding; Faulting; Unconformities.

Conglomerates; Concretions; Stalactites; Jointing; Cleavage.

Sedimentation; Denudation; Erosion; Caves; Sink holes; Erratic bowlders; Weathering; Wind work; Dunes; Loess; Landslides.

Glaciers; Glacial erosion; Eskers; Kames; Moraines; Kettle holes.

Drainage changes. 


\section{PHYSIOGRAPHIC.}

Geomorphy; Relief maps.

Valleys; Cirques; Deserts; Dunes; Deltas; Alluvial fans; Eskers; Kames; Mounds, natural; Natural bridges; Sink holes; Karsts.

Lakes; Swamps; Marshes; Everglades; Terraces; Shore lines; Rivers; Meanders; Falls; Springs.

6. HISTORICAL OR STRATIGRAPHIC.

Geologic history; Geologic time; Paleogeography; Paleogeographic maps; Paleoclimatology.

Geologic maps; Geologic formations described (list).

Pre-Cambrian, Cambrian; Ordovician; Silurian; Devonian; Carboniferous; Triassic; Jurassic; Cretaceous; Tertiary; Quaternary; Recent; Glacial geology; Glaciation; Glacial lakes; Ice ages.

\section{PALEONTOLOGY.}

Geographic distribution.

Vertebrata; Man, fossil; Mammalia; Aves; Reptilia; Amphibia; Pisces; Footprints, fossil.

Invertebrata; Arthropoda; Trilobita; Ostracoda; Insecta; Arachnida; Myriapoda. Mollusca; Cephalopoda; Gastropoda; Pelecypoda.

Molluscoidea; Brachiopoda; Bryozoa; Vermes.

Echinodermata; Echinoidea; Asteroidea; Crinoidea; Crystoidea.

Coelenterata; Anthozoa; Hydrozoa; Graptolites.

Protozoa; Spongida; Foraminifera.

Paleobotany; Diatoms.

Problematica.

\section{PETROLOGY.}

Rocks, origin; Rocks described (list); Igneous and volcanic rocks; Rock-forming minerals.

\section{MINERALOGY.}

Minerals described (list); Crystallography; Pseudomorphism; Paragenesis of minerals; Rock-forming minerals; Meteorites.

\section{UNDERGROUND WATER.}

Mine waters; Thermal waters; Geysers; Springs; Mineral waters.

11. SOILS.

$56693^{\circ}-$ Bull. $444-10 \longrightarrow 8$ 



\section{INDEX.}

[The numbers refer to entries in the bibliography.]

Aberdeen-Redfield district, Sonth Dakota: Todd 1146.

\section{Abrasive materials.}

North Carolina: Pratt, 964.

United States (general): U. S. G. S., 1170.

\section{Addresses.}

Antiquity of man: Penck, 947.

Darwin and geology: Stevenson, 1106.

Distribution of nation's mineral wealth: Sinith, 1083.

Earthquake forecasts: Gilhert, 450.

Geologic basis for artesian prediction: Darton, 309.

Geologic essentials of a mine report: De Kalb, 330 .

Geologic forecast of the future opportunities of our race: Chamberlin, 217.

Geology and revelation: Calvin, 186.

Igneous rocks, study of: Iddings, 611.

North America and Europe: Penck, 946.

Pleistocene problem in Iowa: Calvin, 187.

Aftonian mammalian fauna: Calvin, 188.

\section{Alabama.}

Economic.

Chattanooga district, iron: Higgins, 556 .

Clinton iron ores in the Birmingham district: Burchard, 163.

Clinton iron ore in Chattanooga region: Burchard, 164.

Coal, Lahausage mine: Evans, 381.

Coosa coal field: Prouty; 971.

Palcontology.

Claiborne fossils: Wheeler, 1225.

\section{Alaska.}

General.

Prince William Sound: Stevens, 1105.

Yakutat Bay region: Tarr and Butler, 1137.

Economic.

Big bonanza copper mine, Latouche Island: Lincoln, 768 .

Fairhaven precinct: Henshaw, 540 .

Fairbanks gold placer region: Prindle and Katz, 970.

Fortymile quadrangle: Prindle, 969

Gold: Rickard, 1002.

Gold Fill district placers: Maddren, 809.

Haines district, gold: Scott, 1043.

Innoko district placers: Maddren, 810 .

Iron Creek region: Smith, 1086.
Alaska-Continued.

Economic-Continued.

Kenai Peninsula: Grant and Higgins, 486.

Kotsina-Chitina, Chistochina, and Valdez Creek regions: Moffit, 873 .

Kotsina-Chitina region, mineral resources: Moffit and Maddren, 875.

Makushin sulphur deposits, Unalaska: Lawton 741.

Mineral resources: Brooks, 149, 150.

Mineral resources, 1908: Brooks et al:; 151.

Mining industry, 1908: Brooks, 148.

Nabesna-White River district: Moffit and Knopf, 874

Peat: Davis, 315

Prince of Wales Island, copper: Scott, 1042.

Prince William Sound: Stevens, 1105.

copper: Grant and Figgins, 485; McCormick 793.

gold: Grant, 484

Ruby Creek district: Maddren, 808 .

Seward Peninsula: Smith, 1085.

Southwestern Alaska: Atwood, 41; Wright 1290

Tin deposits, Seward Peninsula: Knopf, 676.

White River, copper: Lewington, 765 .

Dynamic and structural.

Glaciers: Reid, 994.

Kobuk glacier: Hershey, 546 .

Rock glaciers: Capps, 197.

Yakutat coastal plain formation: Blackwelder, 118 .

Physiographic.

General: Sargent, 1026.

Bogoslofs: Jordan and Clark, 639.

Malaspina glacier region: Martin, 821.

Point Hope spit: Kindle, 667.

Yakutat Bay region: Tarr, 1136.

Stratigraphic.

Balboa-Herendeen Bay district: Atwood, 42.

Cape Thompson section: Kindle, 669 .

Fortymile quadrangle: Prindle, 969.

Kotsina-Chitina region: Moffit and Maddren 875.

White River region, copper-bearing amygdaloids: Knopf, 676.

Yakutat Bay region: Tarr, 1136; Tarr and Butler, 1138.

Paleontology.

Mammoth expeditions: Quackenbush, 974. 
Alaska-Continued.

Petrology.

Scapolite rocks: Spurr, 1091.

Yakutat Bay region: Butler, 174.

Mineralogy.

Pyrite with gold and galena: Pogue, 959.

\section{Alberta.}

Economic.

Bighorn and Brazeau coal lands: Mclevoy, 802 .

Bighorn, Brazeau, and Saskatchewan coal lands: Dowling, 353 .

Big Horn coal basin: Malloch, 812 .

Coal: Scott, 1041.

Coal fields: Dowling, 350, 352 .

Kananaskis coal area: Dowling, 355; McEvoy, 801.

Lignite areas: Dowling, 351.

Mining districts: Langford, 737.

Dynamic and structural.

Landslide at Frank: Burling, 168.

Algae from Trenton limestone of New York: Ruedemann, 1020 .

Algonkian. See Pre-Cambrian.

Algonquin and Nipissing shore lines in Ontario: Goldthwait and Jacobson, 463.

Aluminum.

United States (general): U. S. G. S., 1170.

Ammonites. See Cephalopoda.

Amphibia.

General: Moodie, 876 .

Carboniferous: Moodie, 878 .

classification, etc.: Moodie, 877.

in $A$ merican Miseum of Natural History: Moodie, 880

Diplocaulus: Williston, 1258.

Lysorophida: Moodie, 876.

Microsauria: Moodie, 879.

Stegocephala: Moodie, 876 .

Trematops from the Permian: Williston, 1260.

Amphibolites of the Laurentian area: Adams, 2.

Analyses, chemical. See list, p. 158.

Animikie. See Pre-Cambrian.

Anthozoa (corals).

Cincinnatian: Foerste, 412.

Developmental stages: Grabau; 475.

Rugose corals, morphology and development: Brown, 156.

Silurian fossils from Ohio, Indiana, and Kentucky: Foerste, 409.

\section{Anthracite.}

Pennsylvania, Wilkesbarre: Cist, 227.

Anticlinal and hydraulic theories of oil and gas accumulation: Munn, 889 .

Anticlinal theory of oil and gas accumulation: Clapp, 231.

Antimony.

Canada: Young, 1297.

Nova Scotia, West Gore: 1.Taley, 503.

Quebec: Dresser, 361 .

United States (general): U. S. G. S., 1170.

Apatite.

Canada: Young, 1297.

Archean. Sec Pre-Cambrian.
Arizona.

General.

T'ucson: Blake, 120.

$\because 1 ;$

Economic.

Banner mining district, Gila County: Brooks, 152.

Calizona placers: Hedburg, 534.

Copper Creek mining district: Sibley, 1062.

Copper fields of southern Arizona: Tolman, 1150 .

Dragoon tungsten deposits: Richards, 996 .

Globe, copper: Sivyer, 1067.

Greens Valley district: Hedburg, $\mathbf{5 3 5 .}$

Johnson and Dragoon districts, copper: Dinsmore, 342 .

Marble prospects in Chiricahua Mountains: Paige, 927 .

Miami copper mine: Herrick, 545 .

Miami-Inspiration copper-ore zone: Tolman, 1152.

Mohave County, mineral deposits: Schrader, 1034 .

Patagonia district: Dinsmore, 341 .

Ray chalcocite deposits: Tolman, 1151.

Ray copper district: Truesdell, $115 \overline{5}$.

Ray copper mines: Herrick, 544 .

San Francisco district: Martin, 816 .

Silverbell copper deposits: Tolman, 1153.

Tombstone district: Shaw, 1055.

Turquoise mining district: Platt, 956.

Wolframite in Whetstone Mountains: Hess, 550.

Dynamic and structural.

Erosion and deposition in bolson region: Tolman, 1149.

Physiographic.

Bolson region: Tolman, 1150.

Colorado Canyon: Davis, 319-321.

Grand Canyon district: Johnson, 629.

Grand Canyon of Colorado: Davis, 319.

Meteor Crater: Hastings, 516.

Stratigraphic.

Ray copper district: Truesdell, 1155.

Tumamoc Hills: Tolman, 1148.

Petrology.

Tumamoc Hills: Tolman, 1148.

Mincralogy.

General: Blake, 119.

Arizonite: Palmer, 934 .

Connellite and chalcophyllite from Bisbee: $\mathrm{Pa}$ lache and Merwin, 932.

\section{Arkansas.}

General.

Bibliography of geology of Arkansas: Branner, 136.

Economic.

Diamond field, Pike County: Arkansas Diamond Company, 29; Branner, 137; Eberle, 369; Fuller, 431; McCount, 794.

Mineral resources: Estes, 380.

Murfreesboro eruptives magnetic: Harris, 513.

Slate: Purdue, 972 .

Stratigraphic.

Ouachita Ordovician area: Purdue, 973.

Arsenic.

United States (general): U. S. G. S., 1170.

Artesian waters and wells. See Underground water 
Arthropoda. See also Crustacea, Arachnida, and Insecta.

Asbestos.

General.

Depth of deposits: Cirkel, 226 .

Canada: Young, 1297.

Ontario, Gowganda district: Collins, 276.

Ontario, Montreal River district: Collins, 279.

Quebec: Dresser, 359-361.

United States (general): U. S. G. S., 1170.

Wyoming: Lakes, 710 .

Asphalt. See also Asphaltite and Grahamite. General.

Distribution and mode of occurrence: Lakes, 708.

Nevada, northeastern: Anderson, 27.

Oklahoma: Gould, 468, 469; Taff, 1130.

United States (general): U. S. G. S., 1170.

Associations, meetings.

American Association for the Advancement of Science, Section E, Baltimore meeting, 1908: Gulliver, 501.

American : Society of Vertebrate Paleontologists, seventh annual meeting: Matthew, 838.

British $\Lambda$ ssociation for the Advancement of Science, Winnipeg meeting: Knight, 673.

Geological Society of $A$ merica, meeting, December, 1908: Hovey, 596.

Geological Society of America, 29th meeting, at Albuquerque: Hovey, 595.

Geologists of northeastern United States, second annual spring conference: Wherry, 1228.

New England intercollegiate geological excursion: Brown, 155.

\section{Asteroldea.}

Protaster: Parks, 941.

\section{Atmosphere.}

Equilibrium between carbon dioxide of atmosphere and calcium compounds of water: Stieglitz, 1109.

Aves (birds).

Peacock from Quaternary asphalt beds, California: Miller, 863.

Teratornis from Rancho La Brea: Miller, 864 .

Barite. See also Barytes.

Canada: Young, 1297.

Missouri, St. Francois and Washington counties: Buckley, 158.

Pennsylvania, Mercersburg-Chambersiburg district: Stose, 1119.

Barytes. See also Barite.

United States (general): U. S. G. S., 1170.

Base level of eolian erosion: Keyes, 655 .

Batrachia. See Amphibia.

Bauxite.

United States (general): U. S. G. S., 1170.

Beaches. See also Shore lines; Terraces.

Ohio, Berea, Cleveland, and Euclid sheets: Carney, 202.

Ontario, southwestern: Taylor, 1140.

Belle Fourche quadrangle: Darton and O'Harra, 312.
Benitoite: Baumhauer, 85; Hlawatsch, 578-580; Londerback, 781 .

Bentonite.

Wyoming, Black Hills region: Darton, 306 .

Wyoming, Laramie Basin: Darton and Siebenthal, 313.

\section{Bibliography.}

Abrasive materials: U. S. G. S., 1169.

Alaska, Pleistocene mammals: Quackenbush, 974 .

Yakutat Bay region: Tarr, 1136.

Alberta, coal fields: Dowling, 350 .

Aluminum: U. S. G. S., $1169,1170$.

Antimony: U. S. G. S., 1169.

Arkansas geology: Branner, 130.

Asbestos: U. S. G. S., 1169.

Asphalt: U. S. G. S., 1170.

Barite: U. S. G. S., 1169.

Barytes: U. S. G. S., 1170.

Bauxite: U. S. G. S., 1170 .

Beaches, raised, of Ohio: Carney, 202.

British Columbia, coal fields: Dowling, 350 .

Building stone: U. S. G. S., 1169.

Canada Geological Survey publications: Canada G. S., 195.

Cement materials: U. S. G. S., 1169.

Cement, Virginia: Bassler, 78.

Cenozoic mammal horizons: Osborn, 913.

Chromium: U. S. G. S., 1169.

Clays: U. S. G. S., 1169.

Coal, Iowa: Lees, 752.

United States Geological Survey publications on: Lee and Nickles, 749.

Colorado, Hahns Peak region: George and Crawford, 446 .

north central: Henderson, 536 .

Copper: Odendall, 905; U. S. G. S., 1169.

Corals, rugose, morphology and development: Brown, 156.

Cryolite: U. S. G. S., 1170.

Deltas: Smith, 599 .

Entelodontidix: Peterson, 951.

Fletcher, Hugh, writings: Brock, 146.

Florissant fossils: Bather, 84 .

Fluorspar: U. S. G. S., 1169, 1170

Fuller's earth: U.S. G. S., 1169.

Gabb, W. M., writings: Dall, 298.

Glass sand: U. S. G. S., h169, 1170.

Gold: U. S. G. S., 1169.

Granite, economic geology of: Dale, 297.

Graphite: U.S. G. S., 1169, 1170.

Gypsum: U.S. G. S., 1169, 1170.

Eeilprin, Angelo, writings: Gregory, 492.

Hyatt, Alpheus, writings: Brooks, 153.

Iron: U. S. G. S., 1169, 1170.

Brewster district, New York: Koeberlin, 679.

Lead: U. S. G. S., 1169.

Lime: U. S. G. S., 1169.

Magnesite: U. S. G. S., 1169.

Mammalia, Pleistocene, of Alaska: Quackenbush, 974 .

Manganese: U. S. G. S., 1169.

Manitoba, coal fields: Dowling, 350 .

Mexico, Cretaceous coal fields: Aguilera, 10.

Mica: U. S. G. S., 1169.

Mineral paints: U. S. G. S., 1169, 1170. 
Bibliography-Continued.

Mollusca, post-Eocene marine, of northwest coast of America: Dall, 301.

Montana, Great Falls region: Fisher, 396, 397.

Nevada, Goldfield district: Ransome, 976 .

Humboldt County: Ransome, 980.

New York, geological maps: Leighton, 755 . Pleistocene: Fairchild, 385.

Nickel: U. S. G. S., 1169.

North American geology for 1906-7, 1908: Nickles, $896,897$.

North Carolina, geology, mineralogy, and geography: Laney and Wood, 736.

Nova Scotia, Arisaig section: Twenhofel, 1158.

Peat: Bastin and Davis, 83.

Iowa: Lees, 753.

Petroleum: U. S. G. S., 1170.

Phosphates: U. S. G. S., 1169.

Platinum: U. S. G. S., 1169.

Pleistocene mammals of A laska: Quackenbush, 974.

Pleistocene of New York: Fairchild, 385.

Pre-Cambrian: Van Hise and Leith, 1178.

Pyrite: U. S. G. S., 1169.

Quicksilver: U. S. G. S., 1169, 1170

Road materials: U. S. G. S., 1169.

Safford, James Merrill, writings: Stevenson, 1107.

Salines: U. S. G. S., 1169.

Salt: U. S. G. S., 1170.

Sand: U. S. G. S., 1170.

Saskatchewan, coal fields: Dowling, 350.

Shaler, Nathaniel Southgate, writings: 1051.

Silurian, Arisaig section, Nova Scotia: Twenhofel, 1158.

Silver: U. S. C. S., 1169.

Sulphur: U. S. G. S., 1169.

Tantalum: Hess, 549 .

Tertiary land connection between North and South America: Scharff, 1030, 1031

Texas, El Paso quadrangle: Richardson, 998.

Tin: Hess, 549; U. S. G. S., 1169, 1170.

Tungsten: George, 445; U. S. G. S., 1169, 1170; Walker, 1199

Turtles, Protostegidæ: Wieland, 1249.

United States Geological Survey publications: U. S. G. S., 1168 .

Uranium: U S. G. S., 1169.

Vanadium: U. S. G. S., 1169.

Virginia, cement resources: Bassler, 78.

Zinc: U. S. G. S., 1169

\section{Biography.}

Fletcher, Hugh: Brock, 146; Schuchert, 1038.

Frazer, Persifor: Harrison, 515.

Gabb, William More: Dall, 298.

Hague, James Duncan: Raymond, 985.

Heilprin, Angelo: Gregory, 492.

Hyatt, Alpheus: Brooks, 153.

Lesley, Peter: Ames, 21.

Nettleroth, Henry: Bassler, 80 .

Safford, James Merrill: Stevenson, 1107.

Shaler, Nathaniel Southgate, autobiography: 1051.

Sternberg, Charles H., autoblography: 1099.

Whiteaves, Joseph Frederick: Schuchert, 1037.

Yates, William Smith: McCallie, 789.
Bismuth.

United States (genera1): U. S. G. S., 1170.

Bison occidentalis: Moodie, 876 .

Bivalves. Sce Pelecypoda.

Black Hills region, geology and water resources: Darton, 306.

Bluestone.

New York: Newland, 894

United States (general): U. S. C. S., 1170.

Bogoslofs: Jordan and Clark, 639.

Bolson region of Arizona: Tolman, 1149.

Borate deposits: Wainewright, 1196.

Boron: Wilson, 1265.

Borax.

General: Wilson, 1265

California: Keyes, 660; Wainewright, 1196. United States (general): U. S. G. S., 1170.

Borings.

Canada: Ingall, 613.

Illinois: Udden, 1162

Louisiana, north western: Harris et al., 514.

Maine, southern: Bayley, 87.

Minnesota, Mesabi rocks: Winchell, 1272

Nevada, Lyon County: $\Lambda$ nderson, 26.

Reno region: Anderson, 25.

New York, Manhattan Island: Berkey, 101.

South Dakota: Darton, 307.

Botany, fossil. Sce Paleobotany.

Brachlopoda.

Caney shale fauna, Oklahoma: Girty, 457.

Cincinnatian: Foerste, 412.

Devonian, Montana: Raymond, 982.

Richmond group: Foerste, 414.

Silurian,Indiana, Ohio, and Kentucky: Foerste, 409.

Tennessee, Indiana, and Kentucky: Foerste, 411.

British Columbia.

General.

British Columbia coast: Graham, 479.

Bulkley Valley: Leach, $\mathbf{7 4 2}$.

Texada Island: McConnell, 792 .

Vancouver Island: Clapp, 228.

Economic.

Bear River district: Rush, 1023.

Bulkley Valley: Leach, 742 .

Coal fields: Dowling, 350 .

Lardeau district: Emmons, 375.

Mining districts: Langford, 737.

Mother Lode mine, copper: Allen, 18.

Osoyoos and Similkameen districts: Camseli, 193.

Phoenix, Granby Consolidated, copper: Allen, 19.

Phoenix camp and Slocan district: LeRoy, 762 .

Report Bureau of Mines: Robertson, 1007.

Texada Island: McConnell, 792.

Vancouver Island: Clapp, 228.

Stratigraphic.

Correlation of the international strata: Evans, 382.

Paleontology.

Stepheoceras from Nicola valley: Whiteaves, 1241. 
British Columbia-Continued. Mineralogy.

Pyromorphite: Bowles, 131.

Bromine.

United States (general): U. S. G. S., 1170.

Bryozoa.

Cretaceous, New Jersey: Gregory, 494.

Building stone. See also, Granite, Limestone, and Sandstone.

Florida: Sellards, 1049.

New Jersey: Lewis, 766 .

New York: Newland, 894.

North Carolina: Pratt, 964 .

Oregon, Portland region: Darton, 308.

Pennsylvania, Philadelphia district: Bascom et al., 74 .

Rocky Mountains: Lakes, 702.

United States (general): U. S. G. S., 1170.

Washington: Darton, 308.

West Virginia: Grimsley, 490.

Marshall, Wetzel, and Tyler counties: Hennen, 537 .

Calcite: Whitlock, 1242.

Calcite, crystallographic notes on: Pogue, 958.

Calcite crystals with new forms: Schaller, 1029.

Caliche: Blake, 120.

California.

General.

Del Norte County, Black Diamond: Hershey, 547.

Santa Cruz quadrangle: Branner ct al., 138.

Economic.

Alleghany gold district: Martin, 817 .

Amador County gold belt: Storms, 1117.

Borate deposits: Wainewright, 1196.

Borax deposits: Keyes, 656, 660 .

Coalinga oil district: Forstner, 422 .

Kreyenhagen field: Forstner, 420 :

Grass Valley, gold mining: Martin, 818 .

Kern County, Yellow Aster mine: Storms, 1116.

Los Angeles oil industry: Barbour, 63.

Mother lode mines: Storms, 1118; Turner, 1157.

San Bernardino County, iron: Jones, 634.

Santa Cruz quadrangle: Branner et al., 138.

Shasta County: Packard, 925.

Sodium sulphate, San Luis Obispo County: . Arnold and Johnson, 34.

Dynamic and structural.

Earthquake rift in eastern San Luis Obispo County: Arnold and Johnson, 33.

San Francisco earthquake: Bogdanovich, 123; Gilbert, 449; Hovey, 594; Klautsch, 672; Kolderup, 680.

earth movements: Oldham: 908.

geodetic study of: Hayford, 531 .

Physiographic.

Physiographic provinces, study of: Holway and Linsley, 589.

San Luis Obispo County: Arnold and Johnson, 33.

Southeastern California: Mendenhall, 845.

Southern California: Danes, 305.

Yosemite region, débris tracks on domes: Matthes, 831.
California-Continued.

Physiographic-Continued.

Yosemite Valley, glacial character of: Matthes, 830.

Stratigraphic.

Coalinga district: Arnold, 31.

Furnace Canyon: Keyes, 656.

Geologic history: Smith, 1084.

Historical geology of California: Forstner, 421. McKittrick-Sunset district: Johnson, 631.

Mount Diablo: Louderback, 782 . .

San Pablo formation: Weaver, 1212.

Santa Cruz quadrangle: Branner et al., 138.

Tertiary: Arnold, 31,32 .

Palcontology.

Carinifex from the Santa Clara lake beds: Hannibal, 507.

Cat allied to Felis atrox: Merriam, 850 .

Coalinga district: Arnold, 30, 31.

Echinoids from the Tertiary: Pack, 923.

Peacock from Quaternary ásphalt beds: Miller, 863.

Santa Cruz quadrangle: Branner ct al., 138.

Teratornis from Rancho La Brea: Miller, 864.

Petrology.

Epidote, pyrogenetic: Butler, 175.

Mineralogy.

Benitoite: Baumhaver, 85; Hlawatsch, 578580.

paragenesis and occurrence: Louderback, 781 .

Calcite crystals: Schaller, 1029.

Natrolite and neptunite from San Benito: Hlawatsch, 581 .

Neptunite from San Benito County: Bradley, 135; Ford, 416.

Underground water.

Ground water problems: Mendenhall, 844 .

Indio region, ground waters: Mendenhall, 846 . Southeastern California: Mendenhall, 845.

Callibrachion: Moodie, 876 .

Cambrian.

General.

Classification: Grabau, $\mathbf{4 7 1}$.

Paleogeographic map: Willis, 1256.

Stratigraphy.

British Columbia: Evans, 382.

Canada, maritime provinces: Matthew, 832 .

Georgia: Veatch, 1184.

Massachusetts, Boston region: La Forge, 690.

Missouri, southeastern: Buckley, 158.

Nevada, Goldfield district: Ransome, 976 .

Silver Peak quadrangle: Turner, 11 б6.

New Brunswick, Saint John: Ells, 373.

New Jersey: Kümmel, 682.

Trenton quadrangle: Bascom et al., 75 .

New York and adjoining States: Gordon, 464.

Pennsylvania, Lancaster County: Roddy, 1008.

Lehigh Valley: Wherry, 1229.

Mercersburg-Chambersburg district: Stose, 1119.

Philadelphia district: Bascom et al., 74 .

Trenton quadrangle: Bascom tt al., 75.

South Dakota, Black Hills region: Darton, 306, 307.

Texas, El Paso quadrangle: Richardson, 998.

Virginia, western: Bassler, 78.

Wyoming, Black Hills region: Darton, 306. 
Cambrian-Continued.

Paleontology.

Early Paleozoic faunas, evolution of: Walcott, 1198.

Pennsylvania, Lancaster County: Roddy, 1008.

Camel from Miocene of Nebraska: Cook, 281.

Camptosaurus, osteology of: Gilmore, 453.

Canada (general). See also the various provinces. General.

Canada Geological Survey publications, 195.

Geology and economic minerals: Young, 1297.

Summary report of Geological Survey for 1908:

Economic. Brock, 144.

Asbestos deposits, depth of: Cirkel, 226.

Economic minerals: Young, 1297.

Mineral districts: Frecheville and Marriott, 426.

Mineral fuels: Ells, 372 .

Mineral production, 1906: Canada, M. B., 194.

Mining districts: Langford, 737.

Peat industry: Nyström and Anrep, 903.

Tungsten: Walker, 1199, 1200.

Stratigraphic.

Geological cycles in the maritime provinces:

Matthew, 832.

Pre-Cambrian rocks: Miller, 865 .

Paleontólogy.

Report on invertebrate paleontology: Ami, 22. Report on paleontology: Whiteaves, 1239.

Report on vertebrate paleontology: Lambe, 724.

Mineralogy.

Report on mineralogy: Johnston, 632.

Underground water.

Report of water and borings branch: Ingall, 613 .

\section{Carboniferous.}

\section{General.}

Paleogeographic map: Willis, 1256.

Theories, new, regarding the Carboniferous period: Bustamante, 173 .

\section{Correlation.}

Fern Glen formation: Weller, 1218.

Stratigraphy.

Alabama: Prouty, 971.

Alaska, Cape Thompson: Kindle, 669 .

Fortymile quadrangle: Prindle, 969.

Arkansas: Purdue, 972.

British Columbia: Evans, 382.

Canada: Dowling, 350.

maritime provinces: Matthew, 832 .

Colorado, Hahns Peak region, Routt County: George and Crawford, 446.

north central: Henderson, 536 .

Conemaugh sections in Pennsylvania: Raymond, 983.

Fern Glen formation: Weller, 1218, 1221.

Georgia: Veatch, 1184.

Guadalupian stratigraphy: Girty, 456 .

Illinois: DeWolf, 337; White, 1232.

Danville region: Wegemann, 1214.

Duquoin: Udden, 1163.

northwestern: Carman, 198.

Indiana: Ashley, 36 .

Iowa, Des Moines stage, general section of: Lees, 751.

eastern: Carman, 198.

southwestern: Smith, 1080 .
Carboniferous-Continued.

Stratigraphy-Continued.

Kansas: Haworth and Bennett, 518. anthracolithic rocks: Beede. 91 . coal measures: Beede and Rogers, 95. Lawrence shales: Yates, 1295.

Permian: Beede 90.

upper Paleozoic plants: Sellards, 1045.

Kentucky: Miller, 859 .

Bedford formation: Foerste, 410 .

Blue Grass region: Matson, 827 .

Waverly formations: Morse and Foerste, 887.

Little Black Mountain region: Fisher, 398.

Massachusetts, Boston region: La Forge, 690.

Michigan, Tuscola County: Cooper, 285.

Montana, Great Falls region: Fisher, 396, 397.

Lewistown field: Calvert, 185 .

New Brunswick: Wilson, 1268.

New Mexico, Hanover district: Paige, 926.

Manzano group: Lee, 745 .

Nova Scotia, Cumberland: Poole, 962.

Joggins section: Logan, 777.

Northumberland County: Fletcher, 404.

Ohio, Conemaugh formation: Condit, 280 .

Licking County: Carney, 200.

Oklahoma, anthracolithic rocks: Beede, 91 .

Permian: Beede, 90.

Pennsylvania, Conemaugh sections: Raymond, 983.

marine fossils, new horizons for: Raymond, 984.

Meadville: Millward, 870 .

Permian rocks of the Mississippi valley: Beede, 94.

Rio Grande region: Keyes, 665 .

South Dakota, Belle Fourche quadrangle: Darton and O'Harra, 312.

Black Hills region: Darton, 306, 307.

Texas, El Paso quadrangle: Richardson, 998.

Permian red beds: Case, 210.

Wichita-Brazos red beds: Gordon, 466 .

Upper Carboniferous: Girty, 455.

West Virginia, Marshall, Wetzel, and Tyler counties: Hennen, 537.

W yoming, Black Hills region: Darton, 306 .

Laramie Basin: Darton and Siebentha), 313.

Paleontology.

Amphibia: Moodie, 878, 880 .

classification, etc.: Moodie, 877.

Crinoid fauna from Texas Permian: Weller, 1220.

Devonian and Mississippian faunas: Weller, 1219.

Early vertebrate faunas: Williston, 1259.

Fern Glen fauna: Weller, 1218, 1221.

Fish fauna of Albert shales of New Brunswick: Lambe, 724.

Guadalupian fauna: Girty, 456; (review): Beede, 92.

Illinois, Foraminifera: Bagg, 46.

Iowa, southwestern: Smith, 1080.

Kansas, coal measures faunas: Beede and Rogers, 95.

cockroaches from,coal measures and Permian: . Sellards, 1046.

Kansas and Oklahoma: Beede, 91.

Kentucky,Bedford fauna: Foerste, 410. 
Carboniferous-Continued.

Paleontology-Continued.

New Mexico, Manzano group: Girty, 458.

Ohio, Conemaugh formation: Condit, 280 .

Oklahoma, Caney shale fauna: Girty, 457

Paleozoic floras: White, 1231.

Pennsylvania, Devonian and Carboniferous: Millward, 870.

Helodus, n. sp.: Eastman, 365.

Pennsylvanian and Permian faunas of Kansas: Beede, 93 .

Permian insects: Sellards, 1047.

Permian land reptiles: Matthew, 837 .

Trematops from the Permian: Williston, 1260.

Upper Carboniferous: Girty, 455.

Carcharodon: Dean, 332.

Carinifex from Santa Clara lake beds: Hannibal, 507.

Cartography. See also Maps.

New York, geological maps: Leighton, 755.

Cascade basin, coals: Dowling, 351.

Caverns. See Caves.

Caves.

Indiana: Greene, 490.

Mexico, Cacahuamilpa: Urbina, 1174.

\section{Celestite.}

Texas: Hess, 551.

Cement and cement materials.

Colorado: Martin, 819 .

Montana, Havre: Pepperberg, 948.

New York: Newland, 894.

North Dakota, northeastern: Barry and Melsted, 70.

Oregon: Darton, 308.

United States (general): U. S. G. S., 1170.

Virginia, western: Bassler, 78.

Washington: Darton, 308:

Cenozoic mammal horizons of western North America: Osborn, 913.

Central America. See also Costa Rica, Guatemala. etc.

Cephalopoda. See also Mollusca.

Caney shale fauna, Oklahoma: Girty, 457.

Stepheoceras from the British Columbia Jurassic: Whiteaves, 1241.

\section{Changes of level.}

General: Carter, 208.

Florida, southern: Sanford, 1025.

Isobases of post-Algonquin elevation: Goldthwait, 462.

Laurentian lakes basin, recent earth movements: Hobbs, 585.

Massachusetts, Boston and vicinity: Freeman, 429.

Chemical analyses. See list $p .158$.

\section{Chromic iron ore.}

United States (general); U.S. G. S., 1170.

Chromite.

Quebec: Dresser, 361.

Chrowaium.

Canada: Young, 1297.

United States (general): U. S. G. S., 1170.

Cincinnatian fossils: Foerste, 412.
Cirques.

Montana, Crazy Mountains: Mansfield, 813.

\section{Classification.}

Coal: Grout, 499.

Crystals: Swartz, 1120 .

Geologic materials: Grout, 498.

Ontario drift deposits: Coleman, 269.

Pre-Cambrian rocks: Van Hise, 1177.

Clay dunes: Coffey, 265.

Clay. See also Fire clay.

\section{General.}

Colloid matter of clay: Ashley, 38 .

Geological investigation of clay: Ries, 1003. Florida: Matson, 828; Sellards, 1049.

Georgia: Veatch, 1184.

Minnesota: Berkey, 100.

Mississippi, pottery clays: Logan, 778.

New Jersey, Philadelphia district: Bascom $e t$ al., 74.

New York: Newland, 894.

Ontario: Baker, 53, 54; Coleman, 270.

Oregon, Portland: Darton, 308.

United States (general): U. S. G. S., 1170.

West Virginia, Marshall, Wetzel, and Tyler counties: Hennen, $\mathbf{5 3 7}$.

Climate, geologic. See Paleoclimatology.

Ciinton iron ore: Ball, 58.

Maryland: Singewald, 1066.

Pennsylvania: Kelly, 643.

Coal. See also Lignite.

General: Campbell, 190.

Barren zone of northern Appalachian field: White, 1237.

Chemical changes in the formation of coal: Dowling, 356.

Classification of: Collier, 273; Grout, 499.

Determination of depths to horizontal coal seams: Lakes, 712 .

Effect of oxygen in coal: White, 1230 .

Future production: Gannett, 434.

Metamorphism of coals, regional, representation of: White, 1234 .

Origin: Coste, 287.

Oxygen, effect in coal: White, 1230 .

Pressure in the formation and alteration of coal: Dowling, 354.

Rate of deposition: Ashley, 37 .

Resin in Paleozoic coals: White, 1233.

Shortage of coal in northern Appalachian field: White, 1230 .

United States Geological Survey publications on coal: Lee and Nickles, 749.

Alabama, Coosa field: Prouty, 971 .

Lahausage mine: Evans, 381.

Alaska, Fairhaven precinct: Henshaw, 540.

southwestern: Atwood, 41.

Yakutat Bay region: Tarr and Butler, 1138.

Alberta: Dowling, 350, 352; Scott, 1041.

Big Horn basin: Malloch, 812 .

Bighorn and Brazeau coal lands: McEvoy, 802.

Bighorn, Brazeau, and Saskatchewan lands: Dowling, 353 .

Cascade basin: Dowling, 351. 
Coal-Continued.

Alberta-Continued.

Kananaskis area: Dowling, 355; McEvoy, 802. British Columbia: Dowling, 350.

Bulkley Valley: Leach, 742.

Canada: Ells, 372; Young, 1297.

Colorado, Book Cliffs field: Richardson, 1000.

Durango-Monero field: Gardner, 437.

Grand Mesa field: Lee, 743 .

northwestern: Gale, 433.

Illinois: Bain et al., 50; DeWolf, 337.

Duquoin district: Udden, 1162, 1163.

Indiana: Ashley, 35,36 .

Iowa: Beyer, 111; Hinds, 571; Lees, 750; Wilder, 1252.

analyses of coal: Lees and Hixson, 754 .

bibliography of coal: Lees, 752 .

Manitoba: Dowling, 350 .

Maryland, upper Potomac fields: Stoek, 1112.

Mexico, Coahuila: Ludlow, 784.

Coahuila, northern: Aguilera, 10.

Michigan, Tuscola County: Cooper, 285.

Montana, Bridger field: Washburne, 1204.

Bull Mountain field: Richards, 997; Woolsey, 1288.

Crazy Mountains: Stone, 1115.

Custer National Forest: Wegemann, 1215.

Great Falls field: Fisher, 396; Shurick, 1061.

Lewistown field: Calvert, 184, 185.

Miles City coal field: Collier and Smith, 274.

Milk River field: Pepperberg, 949.

Red Lodge field: Woodruff, 1283.

Roundup mines: Rowe, 1018.

Sentinel Butte lignite field: Leonard and Smith, 761.

Newfoundland: Howley, 604 .

New Mexico, Dawson: Sheridan, 1057.

Durango-Monero field: Gardner, 437.

Gallina-Raton Spring field: Gardner, 436.

Gallup-San Mateo field: Gardner, 438.

North Dakota, Sentinel Butte field: Leonard and Smith, 761.

southwestern: Leonard, 758.

Oklahoma: Gould, 470.

Oregon, Morrow County: Mendenhall, 849.

Rogue River valley: Diller, 339.

Saskatchewan: Dowling, 350 .

Cascade basin: Dowling, 351 .

United States (general): U. S. G. S., 1170

coal fields: Campbell and Parker, 191.

Utah, Book Cliffs field: Richardson, 1000. northeastern: Gale, 433.

southern: Richardson, 999

Virginia, Pocket coal district in Little Black Mountain field: Fisher, 398 .

Washington: Tarr, 1134.

Olympic Peninsula: Reagan, 989.

West Virginia: Stoek, 1110; White, 1231.

central: Stoek, 1113.

Marshall, Wetzel, and Tyler counties: Hennen, 537.

upper Potomac fields: Stoek, 1112.

Wyoming, Bighorn Basin: Washburne, 1204; Woodruff, 1284 .

Black Hills'region: Darton, 306.

Glenrock field: Shaw, 1054.

Great Divide Basin field: Smith, 1077.
Coal-Continued.

Wyoming, Bighorn Basin-Continued.

Laramie Basin: Darton and Siebenthal, 313.

Little Snake River field: Ball, 57.

Rock Springs field, Sweetwater County: Schultz, 1039.

Sheridan field: Taff, 1129.

Yukon: Cairnes, 179.

Coal Measures. See Carboniferous.

Cobalt.

Canada: Young, 1297.

Ontario: Hore, 591.

Cobalt district: Higgins, 557; Ontario D. M., 909.

United States (general): U. S. G. S., 11\%0.

Colenterata. See Anthozoa and Hydrozoa.

Coke.

United States (general): U. S. G. S., 1170.

Colloid matter of clay: Ashley, 38 .

\section{Colorado.}

General.

Geological survey, report: George, 444.

\section{Economic.}

Aspen, ore deposition: Spurr, 1092.

Book Cliffs coal field: Richardson, 1000 .

Boulder County tungsten area: George, 445.

Boulder oil field: Washburne, 1025.

Cement materials: Martin, 819 .

Dredging at Breckenridge: Bradford and Curtis, 133.

Durango-Monero coal field: Gardner, 437.

Fall River district, Alice mine: Herrick, 542.

Florence oil field: Washburne, 1206.

Fluorspar: Burchard, 165.

Grand Mesa coal field: Lee, 743 .

Gunnison County: Hill, 562.

Hahns Peak region, Routt County: George and Crawford, 446; Lakes, 707.

Liberty Bell, Telluride: 1304.

Mining districts: Miller, 861 .

Montezuma mining district, Summit County: Patton, 943.

Mineral resources: Lakes, 720 .

Natural gas: Lakes, 706.

Newcastle, gold: Rickard, 1001.

Northwestern coal fields: Gale, 433.

Oil fields: Lakes, 696.

Ore deposition at Aspen: Loughlin, 783.

Rare metals: Fleck, 399, 401.

Summit County: Lakes, 695 .

Taylor Peak and Whitepine iron deposits: Harder, 509.

Tungsten: Ekeley, 370; Hills, 568; Walker, 1199. Boulder County: George, 443 .

Uranium and vanadium deposits: Fleck, 400. Dynamic and structural.

Landslides in San Juan Mountains: Howe, 603. Slumgullion mud flow: Cross, 296.

Physiographic.

Mills moraine, Longs Peak region: Orton, 912. Stratigraphic.

Book Cliffs soal field: Richardson, 1000.

Boulder County, 'Sugarloaf district: Crawiord, 290.

Fluidal gneiss and contemporary pegmatites: Cross, 295. 
Colorado-Continued.

Stratigraphic-Continued.,$\therefore$,

Foothills formations of north central Colorado: Henderson, 536.

Grand Mesa coal field: Lee, 747 .

Gunnison County: Hill, 562.

Hahns Peak region, Routt County: George and Crawford, 446 .

Leadville quadrangle, Pleistocene geology of: Capps, 196.

Morrison formation: Henning, 537.

Sugarloaf district, Boulder County: Crawford, 290.

\section{Paleontology.}

Amber in Laramie: Cockerell, 263.

Ceropalidæ from Florissant: Rohwer, 1013.

Coleoptera from Florissant: Wickham, 1247.

Devonian fauna of the Ouray limestone: Kindle, 666 .

Diptera from Florissant: Cockerell, 250.

Eocene insects: Cockerell, 246, 255.

Euphorbiaceæ: Cockerell, 262.

Fagaceæ: Hollick, 587.

Florissant fossils: Bather, 84 .

Florissant insects: Cockerell, 243-245, 247-257; Rohwer, 1013, 1014; Wickham, 1247.

Florissant plants: Cockerell, 264.

Ground-sloth: Cockerell, 261.

Nemestrinidæ: Cockerell, 244, 245.

Tsetse fly from Florissant: Cockerell, 252.

Petrology.

Boulder County, intrusive rocks: Craw ford, 291.

Sugarloaf district: Crawford, 290 .

Crystalline slates from Las Animas Canyon: Berg, 96.

Sugarloaf district: Crawford, 290.

Mineralogy.

Bald Mountain, minerals with uranium ore: Becke, 88 .

Guffey meteorite: Hovey, 598.

Underground water.

Artesian waters of Costilla County: Headden, 532.

Mineral springs: Headden, 533 .

Colorado Canyon: Davis, 319-321, 324.

Colorado desert: Mendenhall, 846, 848 .

Concentration versus transportation: Shattuck, 1053.

\section{Conglomerates.}

Marine and terrestrial: Barrell, 68.

Congresses. See Associations.

\section{Connecticut.}

Stratigraphic.

General: Gregory, 493.

Lighthouse granite: Ward, 1201.

Petrology.

Lighthouse granite: Ward, 1201.

Underground water.

General: Gregory, 493.

Ground water in the crystalline rocks: Ellis, 371.

Contact phenomena.

Granodiorite of Concepcion del Oro, Zacatecas, Mexico: Bergeat, 97.

Idaho, Cœur d'Alene district: Calkins, 182.
Contact phenomena-Continued.

Massachusetts, Newburyport: Clapp and Ball, 229.

Nevada, Silver Peak quadrangle: Turner, 1156. Convexity of hilltops: Gilbert, 451.

Coon Butte: Merrill, 855 .

\section{Copper.}

General: Emmons, 378.

Copper in sandstone: Jenks, 620.

Garnet contact deposits, depths at which formed: Keyes, 654

$\Lambda$ laska, Kenai Peninsula: Grant and Higgins, 480.

Kotsina-Chitina region: Moffit and Maddren, 875.

Kotsina-Chitina, Chistochina, and Valdez Creek regions: Moffit, 873 .

Latouche Island: Lincoln, 768.

Nabesna-White River district: Moffit and Knopf, 874.

Prince of Wales Island: Scott, 1042.

Prince William Sound: Grant and Higgins, 485; McCormick, 793.

southeastern: Wright, 1290.

White River district: Lewington, 765.

Arizona, Banner mining district: Brooks, 152.

Copper Creek district: Sibley, 1062.

Globe: Sivyer, 1067.

Johnson and Dragoon districts: Dinsmore, 342 .

Miami mine: Herrick, 545.

Miami-Inspiration ore zone: Tolman, 1152.

Mohave County: Schrader, 1034.

Ray chalcocite deposits: Tolman, 1151.

Ray copper district: Truesdell, 1155.

Ray mines: Herrick, 544 .

Silverbell deposits: Tolman, 1153.

southern: Tolman, 1150.

British Columbia, Mother Lode mine: Allen, 18.

Osoyoos and Similkameen districts: Camsell, 193.

Phoenix, Granby Consolidated: Allen, 19.

Slocan district: Le Roy, 762 .

Texada Island: McConnell, 792

Vancouver Island: Clapp, 228.

California, Shasta County: Packard, 925.

Canada: Young, 1297.

Colorado, Montezuma district, Summit County: Patton, 943.

Idaho, Cœur d'Alene district: Rowe, 1016 .

Jamaica: Outerbridge, 921, 922.

Mexico: Balarezo, 55.

Chihuahua, Terrazas: Baron, 67.

Guerrero, Cerro Seco: Paredes, 938.

Jalisco, Magistral district: Babb, 44.

Michoacan: Bigot, 114.

Zacatecas, Concepcion del Oro district: Chase, 221.

Michigan: Hore, 592; Lane, 729.

Nevada, Humboldt County: Ransome, 980, 981.

Ely: De Kalb, 333.

Lida district: Root, 1015.

Mason mining district, Lyon County: Zehring, 1302.

White Pine district: Larsh, 738.

Yerington: Jennings, 625; Ransome, 979. 
Copper-Continued.

New Jersey: Kümmel, 686.

New Mexico, Black Range mining district: Wright, 1294.

North Carolina: Pratt, 964.

Gold Hill district: Laney, 735 .

Nova Scotia, Cape Breton Island, South Cheticamp: Grandin, 481.

Oregon, Grants Pass: Diller and Kay, 340.

Porto Rico: Hamilton, 505.

Quebec: Dresser, 361 .

Opasatika Lake district: Cirkel, 225.

United States: Lindgren, 772; Odendall, 905; U. S. G. S., 1170.

Utah, Bingham district: De Kalb, 335; MacFarlane, 804 .

Box Elder County: Higgins, 559.

Utah copper mine: De Kalb, 334.

Vermont, Orange County: Fay, 391; Judson, 640.

Virginia, Greene County: Haney, 506.

Wisconsin, southwestern: Cox, 289.

Yukon: Cairnes, 179.

Whitehorse belt: McConnell, 791; Stutzer, 1121.

Corals. See Anthozoa.

Correlation. See Stratigraphic.

Corundum.

Canada: Young, 1297.

Cotylosauria: Moodie, 876.

Crazy Mountains, glaciation: Mansfield, 813.

\section{Cretaceous.}

General.

Paleogeographic map: Willis, 1256.'

Stratigraphy.

Alaska, Kotsina-Chitina region: Moffit and Maddren, 875.

Albérta: Dowling, 352.

British Columbia, Vancouver Island: Clapp, 228.

California, Coalinga district: Arnold, 31.

McKittrick-Sunset district: Johnson, 631.

Santa Cruz quadrangle: Branner et al., 138.

Canada: Dowling, 350 .

Ceratops beds: Stanton, 1094.

Colorado: Martin, 819.

Book Cliffs region: Richardson, 1000.

Florence oil field: Washburne, 1206.

Grand Mesa coal field: Lee, 743 .

Hahns Peak region, Routt County: George and Crawford, 446.

north central: Henderson, 536 .

northwestern: Gale, 433.

southern: Gardner, 437.

Georgia: Veatch, 1184.

Laramie formation and Shoshone group: Cross, 294.

Louisiana, northwestern: Harris et al., 514 .

Magothy formation on the Atlantic islands: Bibbins, 113.

Mesozoic invertebrate faunas: Stanton, 1094.

Mexico, Chihuahua, Ias Plomosas: Burrows, 171.

Coahuila: Aguilera, 10.

Guanajuato district: Botsford, 129.

Ixmiquilpan Valley, Hidalgo: Paredes, 940.

\section{Cretaceous-Continued.}

Stratigraphy-Continued.

Mexico, Chihuahua, etc.-Continued.

Rio Nazas region: Burckhardt and Villarello, 166.

Montana: Pepperberg, 948.

Bull Mountain coal field: Richards, 997.

- Crazy Mountains: Stone, 1115.

Fort Peck Indian Reservation lignite field: Smith, 1076.

Great Falls region: Fisher, 396, 397.

Lewiston field: Calvert, 185.

Milk River coal field: Pepperberg, 949.

Sweetgrass County: Douglass, 348.

New Jersey: Kümmel, 682.

Philadelphin district: Bascom et al:, 74.

Trenton quadrangle: Bascom et al., 75 .

New Mexico, Gallina-Raton Spring coal field: Gardner, 436.

Gallup-San Mateo field: Gardner, 438.

northern: Gardner, 437 .

Raton field: Lee, 744.

North Carolina: Stephenson, 1098.

North Dakota, northeastern: Barry and Melsted, 70 .

Oklahoma, Madill oil pool: Taff and Reed, 1132.

South Dakota: Dartan, 307.

Aberdeen-Redfield district: 'Todd, 114e.

Black Hills region: Darion, 306.

Belle Fourche quadrangle: Darton and O'Harra, 312.

Texas: Harris, 512.

chalk formations: Gordon, 465; Hill, 563.

El Paso quadrangle: Richardson, 998.

Utah, Book Cliffs region: Richardson, 1000. northeastern: Gale, 433 .

southern: Richardson, 999.

Washington, Olympic Peninsula: Reagan, 989.

Wyoming, Bighorn Basin: Washburne, 1204; Woodruff, 1284.

Black Hills region: Darton, 306

Glenrock coal field: Shaw, 1054.

Great Divide Basin coal field: Smith, 1077.

Laramie Bंasin: Darton and Siebenthal, 313.

Iittle Snake River coal field: Ball, 57.

Sweetwater County: Schultz, 1039.

\section{Palcontology.}

Araucariopitys: Jeffrey, 617.

California, Coalinga district: Arnold, 31.

Colorado, amber in Laramie: Cockerell, 263.

Echinoids from .Ripley group of Mississippi: Slocom, 1069.

Flora of A tlantic coastal plain: Berry, 105.

Floras of Virginia. and North Carolina: Berry, 109.

Mesozoic invertebrate launas: Stanton, 1094.

Mexico: Aguilera, 8.

Montana, crocorlile from Judith River beds: Holland, 586 .

New York, Cretaceous coniferous remains from Kreischerville: Hollick and Jeffrey, 588.

Pines, leaf structure of: Jeffrey, 618.

Saurian from the Niobrara: Wieland, 1250.

Crinoldea. See also Echinodermata.

Jurassic: Springer, 1090.

Periglyptocrinus priscus, ornamentation of: Parks, 942. 
Crinoidea-Continued.

Permian crinoid fauna, Texas: Weller, 1220. Troost's crinoids of Tennessee: Wood, 1280 .

Uintacrinus socialis: Bassler, 81 .

\section{Cryolite.}

United States (general): U.S. G.'S., 1170.

Cryptograms. See Paleobotany.

\section{Crystallography.}

General: Wadsworth, 1195 .

Alamosite, Mexico: Palache and Merwin, 931. Albite: Grosspietsch, 497 .

Arizonite: Palmer, 934.

Benitoite: Baumhauer, 85; Hlawatsch, 578-580; Louderback, 781; Palache, 929.

Calamine crystals from Organ Mountains, New Mexico: Ford and Ward, 419.

Calcite: Pogue, 958.

from Kelly's Island: Ford and Pogue, 417.

from New Jersey trap region: Whitlock, 1242.

Calomel from Texas: Goldschmidt and Mauritz, 459.

Chalcophyllite: Palache and Merwin, 932.

Classification of crystals: Swartz, 1126.

Connellite: Palache and Merwin, 932.

Crystals, classification of: Swartz, 1126.

Datolite, New Jersey: Ford and Pogue, 418.

Greenland minerals: Böggild, 124.

Hastingsite from Ontario: Graham, 480.

Todyrite: Kraus and Cook, $6 S 1$.

Leadhillite: Palache and La Forge, 930.

Mercury minerals from Tcrlingua, Texas: Hillebrand and Schaller, 56.5 .

Minerals from Chester, Mass.: Palache and Wood, 933.

Neptunite: Ford, 41 ic.

Optical mineralogy, elements of: Winchell and Winchell, 1273.

Pyrite carrying gold and galena of unusual habit: Pogue, 959.

Pyrite from Utah: Rogers, 1010.

Pyromorphite: Bowles, 131.

Cuba. See also West Indies.

Economic.

Iron ores, residual brown: Weld, 1217.

Curaçao: Cleland, 241.

Cycads, fossil: Wieland, 1251.

Dæmonelix, origin: Riggs, 1004.

Dawsonite: Graham, 478 .

Definitions. See Nomenclature.

\section{Deformation.}

Earth's rotation, bearing on deformation: Chamberlin, 214.

Deinosuchus hatcheri: Holland, 586.

\section{Delaware.}

General.

Philadelphia district: Bascom et al., 74 .

Deltas.

Experiments in delta formation: Smith, 1070.

Denudation. See also Erosion.

Rate of, error in estimating: Free, 427.

Deposition. Sce Sedimentation.

Deposition of ores. See Ore deposits, origin.

Desert, lineaments of: Keyes, 661 .
Desert varnish: Surr, 1125; Turner, 1150.

Deserts.

Colorado Desert: Mendenhall, 848.

Devonian.

Gencral.

Evolution of North America: Grabau, 472.

Paleogeographic map: Willis, 1256.

Corrclation.

New York, Watkins Glen-Catatonk district: Williams et al., 1255.

\section{Stratigraphy.}

Alaska, Fortymile quadrangle: Prindle, 969 .

British Columbia, Vancouver Island: Clapp, 228.

Canada: Dowling, 350 .

maritime provinces: Matthew, 832 .

Colorado, Ouray limestone: Kindle, 666.

Gaspe sandstone, age of: Williams, 1254.

Georgia: Veatch, 11.84.

Illinois, northwestern: Carman, 198.

Iowa, eastern: Carman, 198.

Kentucky, Blue Grass region: Matson, 827.

Louisville region: Bassler, 80 .

Missouri, central: Greger, 491.

New Brunswick: Wilson, 1208.

New Jersey: Kümmel, 682 .

New York, Watkins Glen-Catatonk district: Williams et al., 1255.

Ohio: Stauffer, 1096

Pennsylvania, Mercersburg-Chambersburg district: Stose, 1119.

Wisconsin: Cleland, 242

Paleontology.

Colorado, Ouray limestone: Kindle, 666 .

Devonian and Mississippian faunas: Weller, 1219.

Dinichthyid armor plates from Marcellus shale of New York: Smith, 1072.

Missouri, central: Greger, 491 .

Montana, red shales fauna: Raymond, 982.

Nettleroth collection: Bassler, 80.

New York, Watkins Glen-Catatonk district: Williams et a?., 1255.

Ohio: Stauffer, 1096.

Paleozoic floras: White, 1231 .

Diamonds.

Arkansas: Arkansas D. Co., 29; Branner, 137; Eberle, 369; Fuller, 431; McCourt, 794; Millar, 858:

Diastrophism as the ultimate basis of correlation: Chamberlin, 216.

\section{Diatomaceous earth.}

Florida: Sellards, 1049

Nevado, Reno region: Anderson, 25.

Diatoms.

Diatomaceous dust on the Bering Sea ice floes: Kindle, 668 .

Dikes.

Black dikes: Lakes, 722 .

California, Santa Cruz quadrangle: Branner et al., 138.

Colorado, Sugarloaf district, Boulder County: Crawford, 290.

New York, Brewster iron district: Koeberlin, 679.

in the Hamilton shale: Smith, 1073. 
Dikes-Continued.

North Carolina, Gold Hill district: Laney, 735. Sandstone, Rockwall, Texas: Paige, 928.

Spheroidal weathering of dikes: Kemp, 645; Villars, 1193.

Dinichthyid armor plates from the Marcellus shale: Smith, 1072.

Dinichthyids from northern Ohio: Branson, 140.

Dinosauria, classification and phylogeny: Huene, 607.

Dinosaurs, Cretaceous iguanadont: Osborn, 917.

Dioposide and its relations to calcium and magnesium metasilicates: Allen and White, 20.

Diopside and related minerals: Day, 325 .

Dip and pitch: Raymond et al., 988.

Diplocaulus: Williston, 1258 .

Dislocations. See Faulting.

Distribution. See Geographic distribution.

Domes, origin: Harris, 512.

Drainage changes.

General: Scheffel, 1032.

Intercision, a drainage modification: Goldthwait, 460 .

Illinois, Danyille region: Wegemann, 1214

northwestern: Carman, 198.

Iowa, eastern: Carman, 198.

Kansas: Todd, 1147.

New York, central: Fairchild, 385, 389.

eastern: Cook, 283.

south and west of the Adirondacks: Fairchild, 388.

Watkins Glen-Catatonk district: Williams $e t$ al., 1255.

North America, eastern: Grabau, 473.

North Dakota, Jamestown-Tower district: Willard, 1253.

Ohio, Licking County: Camey, 200; Mather, 824; Scheffel, 1032.

Ontario, southwestern: Taylor, 1140.

Pennsylvania, western: Hice, $\mathbf{5 5 5}$.

Drift. See Glacial geology.

Dromomeryx: Douglass, 349 .

Dunes.

General: Carman, 198.

Clay dunes: Coffey, 265.

Dynamic and structural (general). For regional, see the various States. See also Caves, Changes of level, Concretions, Deformation, Deltas, Domes, Drumlins, Dunes, Earth, genesis of, Earthquakes, Erosion, Eskers, Faulting, Folding, Geysers, Glaciers, Isostasy, Karsts, Landslides, Magmas and intrusions, Marshes, Metamorphism, Mounds, natural, Naiural bridges, Orogeny, Pebbles, Sedimentaticn, Shore lines, Sink holes, Temperature, Terraces, Thermal waters, Uncomformity, Valleys, Volcanoes, W eathering.

Coal, rate of deposition: Ashley, 37 .

Delta experiments: Smith, 1070.
Dynamic and structural-Continued.

Equilibrium between carbon dioxide of atmosphere and calcium compounds of water: Stieglitz, 1109.

Flow of rocks: Adams, 1 :

Gases in rocks: Chamberlin, 213. '

Ice ramparts: Griggs, 495.

Mangroves in southern Florida, geologic work of: Vaughan, 1183.

Slickensides: Lawson, 739

Unconformities, valuation of: Blackwelder, 116 .

Earth, genests of. See also Dynamic and structural (general).

Earth's rate of rotation and bearing on deformation: Chamberlin, 214

History of the earth: See, 1044.

Meteorites, composition of: Merrill, 856 .

Earth, interior of.

General: Carter, 208; Wiechert, 1248.

Earthquakes.

General: Carter, 208, 209; Gill, 452; Hixon, 575; Reid, 993.

Earthquakes and firedamp: 1303.

Effect of earthquakes on deep underground water circulation: Yeandle, 1296.

Harvard seismographic station report: Jaggar, 616; Woodworth, 1287.

Mine explosions and earthquakes: Spalding, 1088.

Records, Albany, New York: Clarke, 240.

Seismic disturbances and coal mine explosions: Stow, 1120.

Seismic geology, evolution and outlook: Hobbs, 582.

Seismological notes: Reid, 993.

Causes, Hobbs, 582; Hovey, 594.

Causes and effects: Hovey, 594.

Charleston: Hovey, 594.

Forecasting: Gilbert, 450 .

Hawaii: Hitchcock, 572 .

Jamaica, Kingston earthquake: Hovey, 594; Marvin, 823.

Mexico, catalog of earthquakes, 1904-1908: Aguilera, 7 .

in 1909: Mexico, I. G., 857.

San Francisco: Bogdanovich, 123; Hovey, 594; Klautsch, 672; Kolderup, 680.

cause: Reid, 993.

earth movements associated with: Oldham, 908.

Echinodermata. See also Asteroidea, Blastoidea, Crinoidea, Cystoidea, and Echinoidea.

Mesozoic and Cenozoic distribution: Clark and Twitchell, 238.

\section{Echinoldea.}

Mississippi, Ripley group: Slocom, 1069.

Tertiary, from California: Pack, 923.

Economic (general). For regional, see the various States. Sce also Ore deposits, origin, and the particular products.

Black dikes: Lakes, 722.

Contributions to economic geology, 1908, part I: Hayes, 527 .

Demonstrating ore formations, new method for: Nicholas, 895 . 
Economic-Continued.

Depth and continuity of fissure veins: Lakes, 723. $\because$. :

Folding of rock strata: Nason, 890 .

History of economic geology in the United States: Emmons, 377 .

Investigations of metalliferous ores in 1908: Lindgren, 770.

Investigations of nonmetalliferous mineral resources and iron ores, 1908: Hayes, 528 .

Mineral production, 1908: U. S. G. S., 1170.

Mineral wealth of the Cordilleras: Raymond and Ingalls, 986 .

Minerals of New England States: Kempton, 648.

Mining terms, definitions: Merrill, 853 .

Ore, definition of: Adams, 5; Herzig, 548; Hills, 567; Kemp, 644; Smith, 1079.

Ore deposition, development of theories of: Emmons, 377 .

Ore deposits connected with placers: Alderson, 15.

Ore shoots: Jennings, 626; Lindgren, 769 .

Organic matter in mines, veins, and ore deposits: Lakes, 698.

Specific volume of ore: Mead, 842 .

Vein and its apex: Finch, 395.

Educational. See also Textbooks.

A pparatus for instruction in geography and structural geology: Hobbs, 583 .

College unit in physical geography: Marbut, 814

Geography at the University of Wisconsin: Martin, 822.

Laboratories for physical geography: Wright, 1289.

Laboratory for physiography: Stearns, 1097.

Laboratory for topographic work: Mead and Martin, 843.

Laboratory manual in physical geography: Hopkins and Clark, 590.

Laboratory methods for geography: Hobbs, 584.

Physical geography in the secondary school: Fenneman, 393.

Physiography in the high school: Fairbanks, 384.

Elevation and subsidence. See Changes of level.

EI Paso quadrangle, Texas: Richardson, 998.

Emery.

New York: Newland, 894.

Enstatite and clinoenstatite: Wright, 1291.

Entelodontidæ, revision of: Peterson, 951 .

Eocene. See Tertiary.

Eolian erosion, base level of: Keyes, 655 .

Erosion. See also Sedimentation and Clacial erosion.

Arizona, southern bolson region: Tolman, 1150 .

Concentration versus transportation: Shattuck, 1053.

Convexity of hilltops: Gilbert, 451

Denudation in the United States: Dole and Stabler, 345, 346 .

Erosion channels, Paleozoic: Ulrich, 1167.

Glacial erosion in America: Carney, 201.
Erosion-Continued.

Great Basin ranges, erosional origin of: Keyes, $652 . ;$

Illinois, northwestern: Carman, 198

Iowa, eastern: Carman, 198.

Missouri River shifting: Duncanson, 364.

Nantucket shorelines: Gulliver, 500 .

Physiographic processes: Fenneman, 392.

St. Vincent Island, Wallibu and Rabaka gorges: Hovey, 597

Valleys, formation of: Hovey, 593.

Weathering and erosion as time measures: Leverett, 763 .

Erratic bowlders.

Bowlder deposits in mid-Carboniferous marine shales: Taff, 1131.

Eruptive rocks. See Igneous and volcanic rocks.

Essays. See Addresses.

Eskers.

New York, Watkins Glen-Catatonk district: Williams et $a l ., 1255$

Eurypterida: Clarke, 240.

Everglades.

Florida, southern: Sanford, 1025.

Faulting.

General.

Faulting, experimental demonstration: Reid. 993.

Fissures, laws of: Stevens, 1104

Geometry of faults: Reid, 992.

Nomenclature: Reid, 992.

Arizona, Grand Canyon district: Johnson, 629.

California, Santa Cruz quadrangle: Branner et al., 138.

Colorado, Aspen: Spurr, 1092

Earth movements associated with San Francisco earthquake: Oldham, 908 .

Faults in seashore cliffs: Lakes, 699.

Great Basin ranges: Keyes, 663 .

Idaho, northern: Calkins, 181.

Maryland, Piedmont region: Mathews and Grasty, 825 .

Mexico, fault zones: Böse, 128 .

Missouri, southeastern: Buckley, 158.

Montana, northwestern: Calkins, 181.

Nevada, Tonopah district: Burgess, 167.

New Jersey, Trenton quadrangle: Bascom $\ell$ al., 75 .

New York, Trenton Falls: Miller, 867.

Oregon, Cracker Creek district: Pardee, 937.

Pennsylvania, Mercersburg-Chambersburg district: Stose, 1119.

Trenton quadrangle: Bascom et al., 75 .

Rocky Mountain faults: Washburne, 1207.

Texas, El Paso quadrangle: Richardson, 998.

Virginia, Piedmont region: Mathews and Grasty, 825 .

southwestern: Bassler, 78 .

Feldspar.

New York: Newland, 894.

Ontario: Morsack, 886:

United States (general): U. S. G. S., 1170.

Fern Glen fauna: Weller, 1218, 1221.

Field work.

Handbook for field geologists: Hayes, 525 . 
Fishes. See Pisces.

\section{Florida.}

General.

Keys, geology of: Vaughan, 1182.

State geologist's report: Sellards, 1048. Economic.

Clays: Matson, 828

Fuller's earth deposits of Gadsden County: Sellards and Gunter, 1050.

Mineral industries: Sellards, 1049.

Phosphate deposits: Van Horn, 1179; Stone, 1114.

Physiographic.

General: Matson and Clapp, 829.

Southern Florida: Sanford, 1025.

Stratigraphic.

Southern Florida: Sanford, 1025.

Stratigraphy: Matson and Clapp, 829.

Flow of rocks' Adams, 1.

\section{Fluorspar.}

Colorado: Burchard, 165 .

Kentucky: Fohs, 415

United States (general): U.S. G. S., 1170

Folded strata, Trenton Falls: Miller, 867.

Folding.

General: Nason, 890.

Mexico: Nason, 890.

Pennsylvania, Mercersburg-Chambersburg district: Stose, 1119

\section{Foraminifera.}

Carboniferous, Illinois: Bagg, 46.

Fossils. See Paleontology.

Fuller's earth.

Florida, Gadsden County: Sellards and Gunter, 1050.

Ganister.

Pennsylvania, Blair County: Butts, 177.

Garnet.

New York: Newland, 894.

Gas. See Natural gas.

Gases in rocks: Chamberlin, 213.

Gastropoda. See also Mollusca.

Auburn chert fauna, Missouri: Branson, 139.

California, Coalinga district, Cretaceous and Tertiary: Arnold, 31 .

Carinifex from Santa Clara lake beds, California: Hannibal, 507.

Fulgur, genesis of: Maury, 841 .

Gems. See.Precious stones.

Genesis of ores. See Ore deposits, origin.

Geochemistry.

Chemical work of U. S. Geological Survey: Clarke, 239 .

Geogenesis. See Earth, genesis of.

\section{Geographic distribution.}

Pacific Coast Tertiary faunas: Arnold, 32 .

Pleistocene Mammalia: Hay, 524.

Tertiary land connection between North and South America: Scharff, 1030.

Tertiary faunas: Dall, 299.

Geologic formations, nomenclature: Keith, 642 .

Geologic formations described. ' See list p. 160.
Geologic formations, tables. See Stratigraphic, Tables of formations.

Geologic history. See also Paleoclimatology and Paleogeography.

Paleozoic.

Ordovicic, Siluric, and Devonic: Grabau, 472.

Post-Paleozoic.

Tertiary, Pacific coast: Arnold, 32 .

of western North America: Osborn, 913.

Regional.

Alaska, Fortymile quadrangle: Prindle, 969.

Arkansas, Ouachita Mountains: Purdue, 972.

California: Forstner, 421; Smith, 1084.

Santa Cruz quadrangle: Branner ct al., 138.

Canada: Young, 1297.

Colorado, north central: Fenderson, 536 .

Florida: Matson and Clapp, 829.

Illinois, northwestern: Carman, 198.

St. Louis area: Fenneman, 392.

Iowa, eastern: Carman, 198.

Kansas, Carboniferous: Beede, 91.

Maine, southern: Clapp, 230.

Massachusetts, Boston and vicinity: Crosby, 293.

Mexico, Ixmiquilpan Valley, Hidalgo: Paredes, 940.

Missouri, St. Louis area: Fenneman, 392.

southeastern: Buckley, 158.

Montana, Cretaceous and Tertiary: Stanton, 1094.

Nevada, Goldfield district: Ransome, 976.

Tonopah district: Burgess, 167.

New Brunswick: Matthew, 832.

New Jersey, Philadelphia district: Bascom et al., 74.

Trenton quadrangle: Bascom et al., 74 .

New Mexico, Rio Grande region: Lee, 745 .

New York, Watkins Glen-Catatonk-district: Williams et al., 1255.

North Carolina, Davidson County: Pogue, 960.

North Dakota: Leonard, 759.

Nova Scotia: Matthew, 832.

Oklahoma, Carboniferous: Beede, 91.

Ontario, Lake Nipigon region: Wilson, 1262:

Lake Wendigokan region: Moore, 884.

Pleistocene: Coleman, 269.

Pacific Coast, Tertiary: Arnold, 32.

Pennsylvania, Mercersburg-Chambersburg district: Stose, 1119

Philadelphia district: Bascom et al., 74 .

Trenton quadrangle: Bascom et al, 75 .

South Dakota, Aberdeen-Redfield district: Todd, 1146.

Black Hills region: Darton, 306.

Belle Fourche quadrangle: Darton and O'Harra, 312.

Texas, El Paso quadrangle: Richardson, 998.

Wyoming, Black Hills region: Darton, 306 .

Cretaceous and Tertiary: Stanton, 1094.

Laramie region, Cenozoic: Blackwelder, 117

Geologic maps.

A laska, Chignik Bay coal field: Atwood, 41.

Cook Inlet region: A twood, 41.

Copper Mountain region: Wright, 1290

Fairbanks region: Prindle and Katz, 970.

Fortymile quadrangle: Prindle, 969. 
Geologic maps-Continued.

Alaska-Continued.

Herendeen Bay coal field: Atwood, 41.

Prince of Wales Island, Kasaan Peninsula: Wright, 1290.

Yakutat Bay region: Tarr and Butler, 1138.

Alberta: Dowling, 352.

coal areas: Dowling, 350 .

Arizona, Tumamoc Hills: Tolman, 1148.

western: Schrader, 1034 .

Arkansas: Purdue, 972.

Ouachita Mountains: Purdue, 973.

California, Santa Cruz quadrangle: Branner et al., 138.

southern, artesian basins: Mendenhall, 844 .

Canada, occurrence of economic minerals: Young, 1297.

Cenozoic mammal horizons of western North America: Osborn, 913.

Coal fields of United States: Campbell, 190.

Colorado, Book Cliffs coal field: Richardson, 1000.

Boulder County: George, 445 .

Boulder County, Sugarloaf district: Crawford 290.

Canyon City embayment: Washburne, 1206 .

Grand Mesa coal field: Lee, 743 .

Gunnison County, southeastern: Hill, $\mathbf{5 6 2}$.

Leadville quadrangle, Pleistocene geology: Capps, 196.

Montezuma district, Summit County: Patton, 943.

north central: Henderson, 536 .

northwestern: Gale, 433.

southern: Gardner, 437 .

Sugarloaf district, Boulder County: Crawford, 290.

Taylor Peak district: Harder, 509.

Whitepine district: Harder, 509.

Connecticut, Lighthouse granite: Ward, 1201.

Florida: Matson and Clapp, 829.

Georgia: Veatch, 1184.

fossil iron ores: Ball, 58 .

northwestern: Ball, 58 .

Greenland, east: Nordenskjöld, 900.

Idaho, northern: Calkins, 181.

Illinois, Cordova quadrangle: Carman, 198.

St. Louis area: Fenneman, 392.

Savanna quadrangle: Carman, 198.

Iowa, Cordova quadrangle: Carman, 198.

Savanna quadrangle: Carman, 198.

Kansas: Haworth et al., 519 .

Kentucky, Blue Grass region: Matson, 827.

Lake Superior region: Brinsmade, 143.

Louisiana-Texas salines: Harris, 512.

Maine; southern: Clapp, 230.

Manitoba, coal areas: Dowling, 35\%.

Massachusetts, Boston Harbor and Charles River estuary: Crosby, 293.

Mexico, Guanajuato district: Villarello et al., 1192.

Queretaro: Paredes, 939.

Missouri, St. Lou is area: Fenneman, 392. southeastern: Buckley, 158.

$$
56693^{\circ}-\text { Bull. } 444-10-9
$$

Geologic maps-Continued.

Montana, Bull Mountain coal field: Richards, 997; Woolsey, 1288.

Crazy Mountains: Stone, 1115.

Custer National Forest: Wegemann, 1215.

Fort Peck Indian Reservation lignite field: Smith, 1076.

Great Falls region: Fisher, 396, 397.

Lewistown coal field: Calvert, 184, 185.

Miles City coal field: Collier and Smith, 274.

Milk River coal field: Pepperberg, 949.

northwestern: Calkins, 181.

Red Lodge coal field: Woodruff, 1283.

Sentinel Butte lignite field: Leonard and Smith, 761 .

Nevada, De Lamar district: Miller, $86 i 2$.

Goldfield district: Ransome, 976 .

Tonopah district: Burgess, 167.

White Pine mining district: Larsh, 738.

Newfoundland: Howley, 604.

New Jersey, Philadelphia district: Bascom $c t$ al., 74 .

New Mexico, Gallina-Raton Spring coal field: Gardner, 436.

Hanover iron district: Paige, 926.

northern: Gardner, 437.

New York: Leighton, 755 .

Brewster district: Koeberlin, 679 .

Geneva-Ovid quadrangles: Luther, 786 .

glacial lake succession: Fairchild, 385.

New York City: Berkey, 101; Gratacap, 487.

Remsen quadrangle: Miller, 867.

Watkins Glen-Catatonk district: Williams et al., 1255 .

North Carolina, Davidson County, Cid mining district: Pogue, 960.

North Dakota, Fort Berthold Indian Reservation lignite field: Smith, 1075.

Sentinel Butte lignite field: Leonard and Smith, 761 .

Washburn lignite field: Smith, 1074

Ohio: Ohio G. S., 906.

Oil and gas fields, 1908: Day, 328.

Oklahoma, Madill oil pool: Taff and Reed, 1132 .

Ontario, Algoma and Thunder Bay districts: Wilson, 1267.

Black Sturgeon Lake region: Coleman, 267.

eastern: Adams and Barlow, 4.

Gowganda district: Collins, 276 .

Gowganda and Miller lakes area: Burrows, 169.

Lake Nipigon-Clay Lake region: Collins, 277.

Lake Wendigokan region: Moore, 884

Oregon, Cracker Creek mining district: Pardee, 937.

Harney Basin region: Waring, 1202.

Portland: Darton, 308.

Pennsylvania, Mercersburg-Chambersburg district: Stose, 1119.

Philadelphia district: Bascom ct al., 74 .

pre-Cambrian, Lake Superior region: Van Hise and Leith, 1178 .

of North America: Van Hise and Leith, 1178. Quebec, iron ore deposits: CirkeJ, 223. 
Geologic maps-Continued.

Saskatchewan, coal areas: Dowling, 350 .

South Dakota: Darton, 307.

$\Lambda$ berdeen-Redfield district: Todd, 1146 .

Black Hills region: Darton, 306.

Belle Fourche quadrangle: Darton and

O'Harra, 31.2.

'T'exas, EI Paso quadrangle: Richardson, 998.

Utah, Book Cliffs cool field: Richardson, 1000 .

northeastern: Gale, 433.

Salt Lake quadrangle: Atwood, 40.

southern, coal fields: Richardson, 999 .

Uinta Mountains, glacial: $\Lambda$ twood, 40 .

Washington, coal areas: 'Tarr, 1134 .

Olympic Peninsula: Reagan, 989.

West Virginia, Marshall, Wetzel, and 'Tyler counties: Hennen, 537.

Wyoming, Bighorn Basin coal field: Washburne, 1204; Woodruff, 1284.

Black Hills region: Darton, 306 .

Glenrock coal field: Shaw, 1054.

Great Divide Basin coal field: Smith, 1077.

Laramie Basin: Darton and Sicbentbal, 313.

Little Snake River coal field: Ball, 57 .

Rock Springs coal field: Schultz, 1039 .

Sheridan coal field: Taff, 1129.

Geologic materials, classification of: Grout, 498.

\section{Geologic time.}

Glacial time: Upham, 1171.

Geological surveys. See Surveys.

-Geometry of faults: Reid, 992.

Geomorphogeny. See Physiographic.

Geomorphology. See Physiographic.

\section{Geomorphy.}

Earth's plan: Taylor, 1141.

\section{Georgia.}

Economic.

Chattanooga district, iron: Higgins, 556.

Clay deposits: Veatch, 1184.

Clinton iron ore in Chattanooga region: Burchard, 164.

Fossil iron ore deposits: Ball, 58.

Gold deposits: Jones, 638.

Manganese deposits: Watson, 1210.

Mincralogy.

Pickens County meteorite: McCallie, 790.

Thomson meteorite: Merrill, 854 .

Gilsonite.

Distribution and mode of occurrence: Isakes, 708.

Glacial deposits, metamorphism or: Carney, 200.

Glacial erosion.

Gencral: Carney, 201.

A laska, Yakutat Bay region: Tarr, 1136.

Hanging valleys: Johnson, 630 .

New York, southwestern Adirondacks: Miller, 868.

Watkins Clen-Catatonk district: Williams et. al., 1255.

Ohio, Kelley's Island: Carney, 205.

Glacial geology. See also Quatemary.

Generai.

Discrimination of glacial drift sheets: Alden, $12,13$.
Glacial geology-Continued.

General-Continued.

Glacial drift sheets discriminated: Alden, 12,13 .

Huronian ice age: Coleman, 271, 272; Knight, 674.

Lake Agassiz: Upham, 1172.

Metamorphism of glacial deposits: Carney, 200.

Pleistocene physical geography: Salisbury, 1024.

Weathering and erosion as time measures: Leverett, 763 .

Alaska, Yakutat Bay region: Tarr, 1136.

Colorado, Leadville quadrangle: Capps, 196.

Illinois, Des Plaines Valley: Goldthwait, 461. northwestern: Carman, 198.

Iowa, eastern: Carman, 198.

Pleistocene problem in Iowa: Calvin, 187.

western, Aftonian sands and gravels: Shimek, 1060.

Kansas, drainage of Kansas ice sheet: Todd, 1147.

Minnesota: Upham, 1171.

Montana, Crazy Mountains: Mansfield, 813.

New Jersey: Kümmel, 682.

New York, $\Lambda$ dirondacks: Miller, 869.

central: Fairchild, 385.

Hudsonian and Ontarian glacier lobes: Fairchild, 387 .

Moravia quadrangle: Carney, 203.

multiple glaciation: Fairchild, 386 .

Remsen quadrangle: Miller, 867 .

southwestern Adirondacks: Miller, 868 .

Watkins Glen-Catatonk district: Williams et al., 1255.

North Dakota, Jamestown-'Tower district: Willard; 1253.

Ohio, Kelley's Island: Carney, 205.

Licking, County: Carney, 200; Mather, 824; Scheffel, 1032.

Ontario, Algonquin and Nipissing shore lines: Goldthwait and Jacobson, 463.

drift deposits: Coleman, 269.

glacial Lake Ojibway: Coleman, 268.

Lake Wendigokan region: Moore, 884 .

Onaman iron range: Moore, 883 .

southwestern: Taylor, 1140.

Pennsylvania, fossils in glacial drift: Millward, 870.

South Dakota, $\Lambda$ berdeen-Redfield district: Todd, 1146.

Wisconsin, deposits on bluffs of Mississippi: Squire, 1093.

southeastern: Alden, 13, 14.

Glacial lakes.

Agassiz: Grant, 483; Upham, 1172; Willard, 1253.

New York: Fairchild, 385.

Watkins Glen-Catatonk district: Williams $e t$ al., 1255.

Ojibway: Coleman, 2 (i8.

Ohio: Carney, 202.

Ontario, Lake Ojibway: Coleman, 268.

St. Lou is and Nemadji Lakes: Winchell, 1270.

Sargent, North Dakota: Willard, 1253.

Shawmut, Massachusetts: Crosby, 293. 
Glacial period, cause: Scharff, 1030.

Glaciated rock: Corss, 286 .

\section{Glaciation.}

Crazy Mountains of Montana: Mansfield, 813. Pre-Cambrian: Coleman, 271, 272; Knight, 674. Uinta and Wasatch Mountains: Atwood, 40.

\section{Glaciers.}

Alaska, Kobuk glacier: Flershey, 546.

Malaspina glacier region: Martin, 821 .

- Yakutat Bay region: Tarr, 1136.

Colorado, Mills moraine, Longs Peak region: Orton, 912 .

Greenland: Nordenskjöld, 900.

Montana, Crazy Mountains: Mansfield, 813.

Variations of: Reid, 994.

Washington, Mount Rainier National, Park: Roberts, 1006 .

Glass sand.

United States (general): U. S. G.: S., 1170.

West Virginia: Grimsley, 496.

Glauconite: Bagg, 46 .

Gold.

General.

Alluvial deposits, origin, character, and dis tribution: Lakes, 703.

Alluvial gold: Garrison, 440 .

Nuggets, origin: Lakes, 704.

Placers: Collins, 275.

Alaska: Brooks, 148; Rickard, 1002.

Fairbanks placer region: Prindle and Katz, 970.

Fairhaven precinct: Henshaw, $\mathbf{5 4 0 .}$

Fortymile quadrangle: Prindle, 969.

Gold Hill district: Maddren, 809.

Haines district: Scott, 1043.

Innoko district: Maddren, 810 .

Iron Creek region: Smith, 1086.

Kenai Peninsula: Grant and Higgins, 486.

Kotsina-Chitina, Chistochina, and Valdez Creek regions: Moffit, 873 .

Nabesna-White River district: Moffit and Knopf, 874

Nizina placer district: Moffit and Maddren, 875.

Prince William Sound: Grant, 483.

Ruby Creek district: Maddren, 808 .

Seward Peninsula: Smith, 1085.

southeastern: Wright, 1290 .

southwestern: $\Lambda$ twood, 41 .

Yakutat Bay region: 'Tarr and Butler, 1138.

Arizona, Calizona placers: Hedburg, 534.

Greens Valley district: Hedburg, 535.

Mohave County: Schrader, 1034.

San Francisco district: Martin, 816.

Tombstone: Shaw, 1055.

British Columbia, Osoyoos and Similkameen districts: Camsell, 193.

Slocan district: LeRoy, 7 (i2.

Texada Island: McConnell, 792 .

Vanconver Island: Clapp, 228.

California, Alleghany district: Martin, 817.

Amador County: Storms, 1117.

Grass Valley: Martin, 818.

Kern County, Yellow Aster mine: Storms, 1116.

Mother Lode: Storms, 1118; Turner, 115it.
Gold-Continued.

Canada: Young, 1297.

Colorado, Breckenridge: Bradford and Curtis, 133.

Fall River district, Alice mine: Herrick, 542 .

Gunnison County: Hill, 562.

Montezuma district, Summit County: Patton, 943.

Newcastle: Rickard, 1002.

Routt County, Hahns Peak region: Cieorge and Crawford, 446

Georgia: Jones, 638.

Idaho, central: Jellum, 619.

Mexico, Arteaga district, Chihuahua: Winston, 1274.

Chihuahua, Calabacillas: Geddes, 441:

El Chico district, Hidalgo: Thomas, 1145. .

El Oro, Esperanza mine: Hindry, 570.

Guanajuato district: Botsford, 129.

Montezuma district, El Tigre mine: Herrick, 543.

Sinaloa, San José de Gracia: Tays, 1143.

Zacatecas, Concepcion del Oro district: Chase, 221.

Nevada, De Lamar mines, Lincoln County: Miller, 862.

Goldfield district: Ransome, 976 .

Hornsilver district: Ransome, 977.

Humboldt County: Ransome, 980, 981.

Lida district: Root, 1015.

Nye County, Manhattan placers: Jones, 635.

Rawhide district: Gehrmann, 442; Whytock, 1245.

Round Mountain, Nye County: Ransome, 978; Loftus, 776 .

Tonopah: Jenney, 624; Johnson, 628. . .

New Mexico, Black Range mining district: Wright, 1294:

Sylvanite: Jones, 636 .

Nicaragua, Matagalpa district: West, 1223.

North Carolina: Lyon; 788; Pratt, 964; Welch, 1216.

- Gold Hill district: Laney, 735 .

Nova Scotia, Kings and Lunenburg counties: Faribault, 385.

Leipsigate district: Moore, 885 .

West Gore: Haley, 503.

Ontario, Lake $A$ bitibi area: Baker, 52 .

Lake Nipigon-Clay Lake règion: Collins, 277.

Rainy River district: Fleming, 403.

Oregon, Bohemia mining district: MacDonald, 798.

Cracker Creek district: Pardee, 937.

Grants Pass: Diller and Kay, 340 .

Rye Valley: Mathez, 826 .

Waldo placers: Nicol, 898 .

Quebec, Riviere Du Loup gold fields: Flind, 569.

United States (general): U. S. G. S., 1170; Lindgren, 772 .

Utah, Box Elder County: Higgins, 559.

Century and Susannah mines, Golden: Higgins, 560 .

Piute County: Higgins, 558.

San Juan River: Lakes, 693.

Washington, Olympic Peninsula: Reagan, 989.

\section{Grahamite.}

Oklahoma: 'Taft, 1130. 
Grand Canyon: Davis, 319 .

Granite.

General: Surr, 1125.

Structural features: Dale, 297.

Maine: Villarello, 1186.

New Hampshire: Villarello, 1181;.

New York: Newland, 894.

North Carolina: Pratt, 964.

South Carolina: Watson, 1211.

United States (general): U. S. G. S., 1170. .

Vermont: Dale, 297.

\section{Graphite.}

Canada: Young, 1297.

Mexico, Santa Maria mines: Hess, $5 \tilde{5} 4$.

Sonora, La Colorado: Hess, 552.

New York: Newland, 894.

Quebec: Brumell, 157 .

United States (general): U. S. G. S., 1170; 1hne, 612.

\section{Graptolites.}

Dendroid graptolites from Hamilton, Ontario: Bassler, 79.

Dictyonema websteri: Ruedemann, 1021.

Gravel.

New York: Newland, 894.

Oregon, Portland: Darton, 308.

United States (general): U. S. G. S., 1170.

Washington, Seattle-Tacoma region: Darton, 308.

Great Falls region, Montana: Fisher, 397.

\section{Greenland.}

General.

Geology and physical geography of east Gireenland: Nordenskjöld, 900 .

Paleontology.

Jurassic fauna: Fraas, 423.

Quaternary Mollusca: Jensen, $62 \bar{i}$.

\section{Mineralogy.}

Albite: Grosspietsch, 497 .

Minerals from basalt of east fireenland: Böggild, 124.

Grenville-Eastings unconformity: Miller and Knight, 860

\section{Guatemala.}

Dynamic and structural.

Volcanoes: Anderson, 27.

Gypsum.

Canada: Young, 1297.

New York: Newland, 894.

Nova Scotia, Cape Breton: 'Jyssowski, 1160.

Oklahoma: Gould, 467.

South Dakota, Belle Fourche quadrangle: Jarton and O'Harra, 312.

Black Hills region: Darton, 306.

United States (general): U. S. G. S., 1170.

Wyoming, Black Hills region: Darton, 306 .

Laramie Basin: Darton and Siebenthal, 313.

\section{Haiti.}

Mineral resources: Ferguson, 394.

Hanging valleys: Johnson, 630 .

\section{Hawaiian Islands.}

Dynamic and structural.

Volcanoes: Hitchcock, 572.

Kilauea: Hitchcock, 573 .
Hawalian Islands-Continued.

Dynamic and structural-Continued.

Volcanoes-Conti nued.

Kilauea and Mauna Loa: Brigham, 141.

Helodus, new species: Eastman, 365 .

History, phllosophy, etc.

Economic geology in the United States: Em. mons, 377 .

Huronian. See Pre-Cambrian.

Ice Age. Ser Glacial geology.

Ice ages.

Huronian, lower: Coleman, 271, 272.

Zonal belt, hypothesis: Wheeler, 1220.

Jcebergs: Tarr, 1136.

Idaho.

Economic.

Central Idaho gold districts: Jellunı, 619 .

Cœur d'Alene district: Calkins, 182; Rowe, 1016; Wiard, 1246; (review) Burkley, 161.

Microstructure of ore from Frisco nine: Campbell, 192.

Northern Idaho: MacDonald, 799.

Phosphate deposits: Van Horn, 1179.

Plicated veins: Lakes, 694.

Vein structure in Monument mine, Lemhi County: Carr, 207.

Stratigraphic.

Northern Idaho: Calkins, 181.

I'etrology.

Northern Idaho: Calkins, 181.

Igneous and volcanic rocks.

ieneral.

Chart of igneous rocks: Croasdale, 292.

Classification, principles of: Waitz, 1197.

Solidification of alloys and magmas: Aston, 39.

Study of: Iddings, 611.

Text-book: Iddings, 610.

A laska, Fortyınile quadrangle: Prindle, 969.

Iron Creek region: Smith, 1086.

Kotsina-Chitina region: Mollit and Maddren, 875.

Arizona, Mohave County: Schrader, 1034

'Tumamoc Hills: 'Tolman, 1148.

California, Santa Cruz quadrangle: Branner $c t$ al., 138.

Colorado, Aspen: Spurr, 1092.

Boulder County: Crawford, 290, 291.

Hahns Peak region, Routt County: George and Crawford, 446.

Montezuma district, Summit County: Patton, 943.

southwestern: Cross, 295.

Connecticut: Gregory, 493.

Lighthouse granite: Ward, 1201.

Georgia: Veatch, 1184

Greenland: Nordenskjöld, 900 .

Idaho, northern: Calkins, 181.

Massachusetts, Boston region: La Forge, (690.

Newburyport: Clapp and Ball, 229.

Mexico: Aguilera, 9.

Baja California: Wittich, 1276 .

Montana, Cra\%y Mountains: Stone, 1115.

Lewistown field: Calvert, 185.

northwestern: Calkins, 181 
gneous and volcanlc rocks-Continued.

Nevada, Goldfield district: Ransome, $\mathbf{9 7 6 .}$

Humboldt County: Ransome, 980.

Silver Peak quadrangle: Turner, 1156.

New Jersey, Highlands: Bayley, 86 .

Trenton quadrangle: Bascom et al., 75 .

New Mexico, Hanover district: Paige, 926.

New York, Brewster iron district: Koeberlin, 679.

Watkins Glen-Catatonk district: Williams $e t$ al., 1255.

North Carolina, Davidson County: Pogue, 960 .

Nova Scotia, A risaig section: T'wenhofel, 1158. volcanic bombs: Poole, 961 .

Ontario, Gowganda district: Collins, 276.

Lake Nipigon region: Wilson, 1262.

Lake Superior region: Collins, 278.

Oregon, : Grants Pass region: Diller and Kay, 340.

Harney Basin region: Waring, 1202.

Portland region: Darton, 308 .

Pennsylvania, Mercersburg-Chambersburg district: Stose, 1119 .

Philadelphia district: Bascom et al., 74 .

pre-Cambrian gneisses of Piedmont plateau: Bascom, 73 .

Trenton quadrangle: Bascom et al., 75.

South Dakota, Black Hills region: Darton, 306.

''exas, F.l Paso quadrangle: Richardson, 998.

Washington, Sawtooth Range of Olympic Mountains: Arnold, 30.

Wyoming, Black Hills region: Darton, 306 .

Sweetwater County: Schultz, 1039.

Yukon, Whitehorse belt: McConnell, 791 .

Iguanodon: Hay, 520.

Iguanodont dinosaurs: Osborn, 917.

Illinois.

General.

Administrative report, 1908: Bain, 49 .

Geological survey, work of: Bain, 47.

Economic.

Coal: Bain et al., 50 .

Coal near Duquoin: Udden, 1162, 1163.

Coal resources: De Wolf, 337 .

Mineral production, 1908: Blatchley, 121.

Natural gas in glacial drift of Champaign County: Knirk, 675 .

Oil and gas in St. Louis district: Wheeler, 1224.

Oil in eastern Illinois: Blatchley, 122.

Petroleum fields: Bain, 48.

Physiographic.

Danville region: Wegemann, 1214.

Des Plaines Valley: Goldthwait, 461.

Mississippi Valley, Savanna-Davenport: CarInan, 198.

St. Louis area: Fenneman, 392.

Stratigraphic.

Danville region: Wegemann, 1214.

Discrimination of drift sheets: Alden, 12.

General notes: White, 1232 .

Glacial drift sheets discriminated: Alden, 12.

Mississippi Valley, Savanna-Davenport: Carman, 198.

Ordovician and Silurian formations in Alexander County: Savage, 1027.

Paleontology.

Fern Glen fauna: Weller, 1218, 1221.
Illinois-Continued.

Palcontology-Continued.

Foraminifera in the Carboniferous: Bagg, 46 .

Mastodon, distribution: Bagg, 45.

Silurian fossils: Foerste, 411 .

Inderground water.

Classification of mineral waters: Bartow, 71 .

Geological classification of the waters of Illinois: Edden, 1161.

Mineral content of Illinois waters: Bartow $c l$ al., 72.

Mineral springs: Palmer, 935.

Indiana.

Economic.

Coal deposits, supplementary -renort: Ashley, 35 .

Coal field, stratigraphy: $\Lambda$ shley, 36 .

Soil survey of Daviess Connty: Snider, 1087 .

of Dubois, Perry, and Crawford counties: Shannon, 1052.

Teat: Taylor, 1139.

Dynamic and structural.

Caves and cave formations of the Mitchell limestone: Greene, 490.

Stratigraphic.

Waldron formation: Kindle and Barnett, 670. Palcontology.

Cincinnatian fossils: Foerste, 412

Silurian fossils: Foerste, $409,411$.

Waldron fauna: Kindle and Barnett, 670 .

Inliers, types of: Ruedemann, 1019.

Insecta.

Cerupalide from Florissant: Rohwer, 1013.

Cockroaches of the Kansas coal measures and Permian:. Sellards, 1046.

Coleoptera from Florissant: Wickham, 1247.

Diptera from Florissant: Cockerell, 250.

Eocene from Colorado: Cockerell, 246, 255.

Florissant, Colorado: Cockerell, 243-245, 247257.

Generic names based on American types: Cockerell, 258 .

Nemestrinidr: Cockerell, 244, 245.

Permian, types of: Sellards, 1047.

Syntomostylus? fortis: Cockerell, 259.

'I'setse fly from Florissant: Cockerell, 252.

Intercision, a drainage modification: Goldthwait, 460.

Intrusions. See also Igneous rocks, Laccoliths, and Magmas.

Lake Nipigon diabase sheets: Wilson, 1262.

New York, Brewster iron district: Koeberlin, 679.

Ontario, Lake Nipigon trap sheets: Wilson, 1262.

Invertebrata (general). See also Anthozoa, Brachlopoda, Bryozoa, Crustacea, Echinodermata, Foraminifera, Insecta, Mollusca, Problematica, Spongida, and Vermes.

California, Coalinga district: Arnold, 30, 31 .

Colorado, Devonian fauna of Ouray limestone: Kindle, 666.

Devonian fauna of Ouray limestone, Colorado: Kindle, 666.

Devonian of Ohio: Stauffer, 1096.

Fern Glen fauna: Weller, 1218. 
Invertebrata-Continued.

Index fossils of North America: Grabau and Shimer, 477.

Mesozoic invertebrate faunas: Stanton, 1094

Miocene of Astoria and Coos Bay, Oregon: Dall, 300 .

National Museum collections: Bassler, 81 .

Nettleroth collection: Bassler, 80.

New Mexico, Manzano group: Girty, 458.

Oklahoma, Caney shale: Girty, 457.

Silurian fossils from Tennessee, Indiana, and Kentucky: Foerste, 411.

Washington, Olympic Peninsula: Reagan, 989. Iodyrite from Tonopah: Kraus and Cook, 681.

\section{Iowa.}

General.

State geologist's seventeenth report: Calvin, 189.

Economic.

Coal deposits: Hinds, 571 .

Coal analyses: Lees and Hixșon, 754

Coal, bibliography of: Lees, 752 .

Coals, fuel values: Wilder, 1252 .

Coal mining, history of: Lees, 750 .

Coal statistics: Beyer, 111.

Mineral production in 1908: Beyer, 110.

Peat: Beyer, 112 .

Peat, bibliography of: Lees, 753.

Physiographic.

Mississippi Valley, Savanna, Davenport: Carman, 198.

\section{Stratigraphic.}

Aftonian sands and gravels in western Jowa: Shimek, 1060.

Carboniferous section of southwestern lowa: Smith, 1080.

Des Moines stage, general section of: Lees, 751 .

Mississippi Valley, Savanna-Davenport: Carman, 158.

Pleistocene problem: Calvin, 187.

Paleontology.

Aftonian mammalian fauna: Calvin, 188.

Iron.

Alabama, Birmingham district: Burchard, 1(i3.

Chattanooga district: Higgins, 556 .

Chattanooga region, Clinton ore: Burchard, 164.

British Columbia, Texada Island: MeConnell, 792.

California, desert region: Jones, 634.

Canada: Young, 1297.

Colorado, Montezuma district, Summit County: Patton, 943.

Taylor Peak and Whitepine deposits: Harder, 509.

Cuba: Weld, 1217.

Georgia: Watson, 1210.

Chattanooga district: Higgins, 550.

Chattanooga region, Clinton ore: Burchard 164.

fossil ore deposits: Ball, 58 .

Maryland: Singewald, 1066.

Mexico: Aguilera, 9.

Chihuahua, Naica district: Reynoso, 995.

Guerrero, Aldama district: Hijar y Haro, 561 .
Iron-Continued.

Michigan mines: Iane, 732 .

Lake Superior district: Brinsmade, 143.

Marquette Range: Stoek, 1111.

Minnesota, Lake Superior region: Brinsmade, 143.

Mesabi Range: Wolff, 1278 .

New Brunswick, Bathurst: Young, 1298.

Newfoundland: Chambers and Chambers, 219; Outerbridge, 922 .

New Mexico, Hanover district: Jaige, 926.

New York: Newland, 894.

Brewster district: Koeberlin, 679 .

Clinton ores: Newland, 892 .

North Carolina: Pratt, 964 .

Nova Scotia: Woodman, 1282.

Ontario, Black Sturgeon region: Coleman, 267. bog ore on English River: Moore, 882 .

Lake Nipigon-Clay Lake region: Collins, 277 .

Lake Superior region: Brinsmade, 143.

Lake Wendigokan region: Moore, 884 .

Montreal River district: Collins, 279.

Nipigon district: Coleman, 266.

north of Round Lake: Moore, 881 .

Onaman Range: Moore, 881.

Thunder Bay and Rainy River districts: Hille, 564 .

Woman River area: Allen, 17.

Pennsylvania, Bloomsburg ore: Van Ingen, 1181.

Clinton ores, Stone Valley: Kelly, 643.

Mercersburg-Chambersburg district: Stose, 1119.

Porto Rico: Hamilton, 505.

Quebec: Cirkel, 223.

chrome ore: Cirkel, 224.

South Dakota, Black Hills: Cooledge and Overspeck, 284.

Tennessee, Chattanooga district: Higgins, 556 .

Chattanooga region, Clinton ore: Burchard, 164.

Texas: Linton, 775.

Llano County: Phillips, 955.

United States (general): U. S. G. S., 1170; Hayes, 529.

iron-ore supply: Hayes, 526.

Virginia, Appalachian region: Harder, 510

West Virginia: Grimsley, 496.

Wisconsin, Lake Superior district: I3rinsmade, 143.

Spring Valley, brown ores: Allen, 16.

\section{Isostasy.}

Figure of the earth: Hayford, 530.

\section{Jamaica.}

General.

Caribbean region, geological connections: Guppy, 502 .

Economic.

Copper mines: Outerbridge, 921 .

Mineral resources: Outerbridge, 922 .

Dynamic and structural.

Kingston earthquake: Hovey, 594; Marvin,823.

Jamestown-Tower district, North Dakota: Willard, 1253.

Jointing.

General: Buckley, 158. 
Juglandaceæ from Pleistocene of Maryland: Berry, 100 .

\section{Jurassic.}

General: Fraas, 425.

Mesozoic invertebrate faunas: Stanton, 1094.

Paleogeographic map: Willis, 1256.

Stratigraphy.

Alaska, Kotsina-Chitina region: Moflit and Maddren, 875 .

California, Coalinga district: Arnold, 31.

Santa Cruz quadrangle: Branner et al., 138 .

Canada: Dowling, 350.

Colorado, north central: Henderson, 536 .

Greenland: Nordenskjöld, 900.

Montana, Great Falls region: Fisher, 396, 397.

Lewistown field: Calvert, 185.

Sweetgrass County: Douglass, 348.

South Dakota: Darton, 307.

Belle Fourche quadrangle: Darton and O'Harra, 312.

Black Hills region: Darton, 306.

Utah, southern: Richardson, 999.

Wyoming, Black Hills region: Darton, 306 .

Laramie Basin: Darton and Siebenthal, 313.

\section{Paleontology.}

Camptosaurus, osteology of: Gilmore, 453.

Crinoid, new: Springer, 1090.

Greenland: Fraas, 423.

Mesozoic invertebrate faunas: Stanton, 1094.

Rhynchocephalian reptile from Wyoming: Gilmore, 454 .

Stepheoceras from British Columbia: Whiteaves, 1241 .

\section{Kansas.}

General.

Fieldwork, history of: Baworth and Bennett, 51.7.

Economic.

Oil and gas: Haworth et al., 519.

Petroleum analyses: Day, 330.

Stratigraphic.

General: Haworth and Bennett, 518.

Anthracolithic rocks of Kansas and Oklahoma: Beede, 91.

Coal measures faunal divisions: Beede and Rogers, 95.

Kansas ice sheet, drainage of: Todd, 1147.

Lawrence shales: Yates, 1295.

Marion stage formations: Beede, 90.

Paleontology.

Bison latifrons skull: Osborn, $91 \mathrm{f}$.

Coal measures faunas: Beede and Rogers, 95 .

Cockroaches from coal measures and Permian: Sellards, 1046.

Dinosaur, armored, from the chalk: Sternberg, 1101.

Euphorbiaceæ: Cockerell, 262.

Paleozoic plants: Sellards, 1045.

Pennsylvanian and Permian faunas: Beede, 93. Saurian from the Niobrara: Wieland, 1249.

Toxochelys stenopora: Hay, 521

Uintacrinus socialis: Bassler, 81.

Kaolin.

Georgia: Veatch, 1184

Mexico, Coahuila: Castro, 212.
Kentucky.

Economic.

Fluorspar: Fohs, 415.

Stratigraphic.

Bedford fauna at Indian Fields and Irvine: Foerste, 410.

Blue Grass region: Matson, 827 .

Connection of coal fields: Miller, 859 .

Kentucky, Louisville region: Bassler, 80.

Waverly formations: Morse and Foerste, 887.

Paleontology.

Bedford fauna at Indian Fields and Irvine; Foerste, 410.

Cincinnatian and Lexington fossils: Foerste; 413.

Cincinnatian fossils: Foerste, 412.

Silurian fossils: Foerste, 409, 411

Underground water.

Blue Grass region: Matson, 827 .

Kilauea: Brigham, 141.

Kinderhook faunal studies: Weller, 1218.

Knightite: Hills, 566 .

Labrador.

General.

Northeastern Labrador: Hantzsch, 508; Uhlig. 1164.

Laccoliths.

Black Hilis region: Darton, 306.

New Mexico: Keyes, 654.

Lakes. See also Glacial lakes.

Divided lakes in western Minnesota: Griggs, 495.

Lakes, glacial. See Glacial lakes.

Lamellibranchiata. Sec Pelecypoda.

Land bridge between northern Europe and North America: Scharff, 1030, 1031.

Landslides.

Alberta, Frank: Burling, 168.

Colorado, San Juan Mountains: Howe, 603.

Slumgullion mud flow: Cross, 296.

New York, landslip in Hudson clays: Newland, 893.

Ohio, near Cleveland: Van Horn, 1180.

Laramie formation and Shoshone group: Cross, 294. Laurentia: Adams, 3.

Lavas, Hawaiian: Brigham, 141.

Lead.

Arizona, Mohave County: Schrader, 1034.

British Columbia, Bear River district: Rush, 1023.

Canada: Young, 1297.

Colorado, Aspen: Spurr, 1092.

Montezuma district, SummitCounty: Patton, 943.

Idaho, Cœur d'Alene district: Rowe, 1016; Wiard, 1246.

Massachusetts, Newburyport: Clapp and Ball, 229.

Mexico, Chihuahua, Las Plomosas: Burrows, 171.

Chihuahua, Naica district: Reynoso, 995.

San Ygnacio: Peragallo, 950.

Guerrero, Pregones district: Laguerenne, 691, 
Lead-Continued.

Missouri: Buck!ey, 160; Keyes, 658 .

Ozark region: Buckley, 159; Keyes, 653 .

Ozark deposits, genesis of: Keyes, 657.

St. Francois and Washington counties: Buckley, 158.

southeast: Ruhl, 1022 .

Nevada, Lida district: Root, 1015.

White Pine district: Larsh, 738.

New Mexico, Tres Hermanas district: Lindgren, 771 .

United States (general): U. S. G. S., 1170; Lindgren, 772 .

Virginia: Caldwell, 180.

Wisconsin: Brinsmade, 142 .

Leadhillite, crystallography of: Palache and La Forge, 930.

Lignite. See also Coal.

Alberta, Cascade basin: Dowling, 351 .

Montana, Fort Peck Indian Reservation field: Smith, 1076.

Sentinel Butte field: Leonard and Smith, 761.

North Dakota, Fort Berthold Indian Reservation field: Smith, 1075.

Sentinel Butte field: Leonard and Smith, 761 . southwestern: Leonard, 758.

Washburn field: Smith, 1074

Saskatchewan, Cascade basin: Dowling, 351.

Lime.

United States (general): U.S. G. S., 1170.

\section{Limestone.}

Colorado: Martin, 819.

New York: Newland, 894.

Oregon: Darton, 308.

United States (general): U. S. G. S., 1170.

Washington: Darton, 308.

Limestones, evolution of: Daly, 303.

Locus of vadose ore deposition: Keyes, 658 .

Loess.

Illinois, northwestern: Carman, 198.

Iowa, eastern: Carman, 198.

Origin: Carman, 198.

St. Louis area: Fenneman, 392.

Louisiana.

Economic.

Oil and gas in northwestern Louisiana: Harris et al., 514 .

Rock salt: Harris, 512 .

Paleontology.

Fulgur, genesis of: Maury, 841 .

Lower Silurian. See Ordovician.

Lymnæa: Baker, 51.

Lysorophidæ: Moodie, 876.

Magmas. See also Intrusions.

General: Lane, 726.

Magmatic waters and volcanic action: Hixon, 574.

Solidification of alloys and magmas: $\Lambda$ ston, 39.

\section{Magnesite.}

United States (general): U. S. G. S., 1170.

Magnetic disturbances and the genesis of petroleum: Becker, 89 .

Magnetic rocks: Harris, 513 .

\section{Magnetite.}

New Jersey: Bayley, 86

Maine.

General.

Kennebec River basin, geology of: Smith, 1081 . Survey Commission, fifth report: $\mathbf{8 1 1}$.

Economic.

Blue Hill copper deposits: Emmons, 378

Deer Isle mine: Emmons, 378.

Granites: Villarello, 1186.

Molybdenite deposits of Tunk Pond: Hills, 566.

Peat deposits: Bastin and Davis, 83 .

Tourmaline deposits: Wade, 1194.

Physiographic.

Kennebec River basin: Smith, 1081

Paleontology.

Ophiuroids in glacial clay: Sayles, 1028.

Shells, fossil and living, in Little Mud Lake: Nylander, 902.

Underground water.

Southern Maine: Clapp, 230.

deep wells: Bayley, 87 .

\section{Mammalia.}

Alaska: Quackenbush, 974 .

Ancodon: Matthew, 835 .

Apternodus and artiodactyl from Wyoming Oligocene: Matthew, 839.

Bison latifrons skull: Osborn, 916.

Camel from lower Miocene of Nebraska: Cook, 281.

Camels of lower Miocene: Loomis; 780.

Carnivores from the Miocene of western $\mathrm{Ne}$ braska: Peterson, 952.

Cat allied to Felis atrox: Merriam, 850.

Cenozolc mammal horizons of western North America: Osborn, 913.

Distribution of Pleistocene Mammalia: Hay, 524.

Dromomeryx: Douglass, 349 .

Entelodontidæ, revision of: Peterson, 951 .

Faunal lists of Tertiary Mammalia of the West: Matthew, 836.

Ground-sloth from Colorado: Cockerell, 248.

Mammoth expeditions to Alaska: Quackenbush, 974 .

Pliocene of western Nebraska: Matthew and Cook, 840 .

Procamelus from Miocene of Montana: Douglass, 347.

Ptilodus: Gidley, 448.

Sea lion from Oregon Miocene: True, 1154.

Strepsicerine antelopes: Merriam, 851 .

Teleoceras from Nebraska Miocene: Olcott, 907.

Man, fossil.

Human race, origin: Wright, 1293.

Man, antiquity of: Penck, 946.

\section{Manganese.}

Canada: Young, 1297.

Georgia: Watson, 1210.

Nicaragua, Matagalpa district: West, 1223.

United States (general): U. S. G. S., 1170; Harder, 511.

Virginia: Ball, 58 .

Mangroves in southern Florida: Vaughan, 1183. 
Manitoba.

Economic.

Coal fields: Dowling, 350 .

Marble.

Arizona, Chiricahua Mountains: Paige, 927.

New York: Newland, 894.

United States (general): U. S. G. S., 1170.

Maps. See Geologic maps.

Marl.

Definition of: Stewart, 1108 .

New Jersey, Philadelphia district: Bascom et al., 74.

Marshes.

Maine: Bastin and Davis, 83 .

Martiniqus.

St. Pierre and Mont Pelé in 1908: Hovey, 601.

Striations and $U$-shaped valleys: Hovey, 593.

\section{Maryland.}

General.

Geological survey report: Clark, 23í-236.

Economic.

Coal, upper Potomac fields: Stoek, 1112.

Iron deposits: Singewald, 1066.

Stratigraphic.

Piedmont limestones: Mathews and Grasty, 825.

Paleontology.

Juglandace from the Pleistocene: Berry, 106.

Miocene drumfish: Smith, 1071.

Tropidoleptus fauna, recurrence of: Swartz, 1127.

Turtle from Miocene: Palmer, 936.

\section{Massachusetts.}

General.

Charles River estuary and Boston Harbor: Crosby, 293.

Economic.

Lead-silver deposits at Newburyport: Clapp and Ball, 229.

Dynamic and siructural.

Subsidence of Boston Harbor: Freeman, 429.

Physiographic.

Nantucket shore lines: Gulliver, 500.

Stratigraphic.

Boston region: La Forge, 690 .

Petrology.

Pegmatite in granite: Warren, 1203.

Mineralogy.

Hampden County minerals: Roe, 1009 .

Minerals from Chester: Palache and Wood, 933.

Mastodon, distribution in Illinois: Bagg, 45.

Mauna Loa: Brigham, 141.

\section{Meandering.}

General: Fenneman, 392.

Missouri River shifting: Duncanson, 364.

Megalosaurus: Hay, $\mathbf{5 2 0 .}$

Meetings. See Associations.

Mercersburg-Chambersburg district, Pennsylvania: Stose, 1119.

Mercury. See Quicksilver.

Mercury minerals from Terlingua, Texas: Hillebrand and schaller, 565 .
Metamorphism.

Chemical composition for identifying metamorphosed sediments: Bastin, 82 .

Glacial deposits: Carney, 200.

Metamorphosed ore deposits: Emmons, 378.

\section{Meteorites.}

General.

Composition of stony meteorites: Merrill, 856 .

Probability of large meteorites having fallen upon the earth: Schwarz, 1040.

Georgia, Pickens County: McCallie, 790.

Guffey, Colorado: Hovey, 598.

Mexico, State of Durango: Agraz, (i.

Modoc: Hovey, 599.

Nevada: Jenney, 621.

Quinn Canyon, Nevada: Jenney, 622.

Thomson, Georgia: Merrill, 854.

\section{Mexico.}

General.

Baja California: Wittich, 1270.

Chihuahua, northeastern: Rogers, 1012.

Coahuila, kaolin in a coal: Castro, 212.

Geology of northern Mexico: Burrows, 171.

Guanajuato district: Villarello et al., 1192.

Instituto Geologico de Mexico: Aguilera, 11.

Ixmiquilpan Valley, Hidalgo: Paredes, 940.

Oaxaca, geology of: Flores, 407 .

Metlacueyatl: Ord6ñez, 911.

Sierra Nevada: Freudenberg, 430.

Economic.

Aldama district, Guerrero: Hijar y Haro, 561 .

Arteaga district: Winston, 1274.

Campeche, Champoton: Urbina, 1175.

Chihuahua, Calabacillas gold mine: Geddes, 441.

Naica mineral district: Reynoso, 995.

Santa Eulalia: Lane, 734; Merrill, 852.

San Ygnacio mine: Peragallo, 950.

Terrazas, copper: Baron, 67 .

Coahuila, carboniferous deposits: $\Lambda$ guilera, 10.

coal: Ludlow, 784 .

Copper deposit in Cerro Seco, Guerrero: $\mathrm{Pa}$ redes, 938.

Copper in Michoacan: Bigot, 114.

El Chico district, Hidalgo: Thomas, 1145.

El Dorado mineral deposits: Balarezo, 56.

Esperanza mine, El Oro: Hindry, 570.

Guanajuato district: Botsford, 129.

Guerrero, Pregones district: Laguerenne, 691.

Iron deposits: Aguilera, 9.

Jalisco, Magistral copper district: Babb, 44 .

Mexico, Zacualpan district: Platt, 957.

Mode of filling of some Mexican ore deposits: villarello, 1191.

Oaxaca, Tehuantepec district: Flores, 408.

Oil fields: Day, 329.

Petroleum of Dos Bocas: Villarello, 1188.

- Petroleum regions: Villarello, 1189, 1190.

Physical and geological features of Mexico mining: Ord6ñez, 910.

Rio Plata mine, Chihuahua: Baron, 66.

- San Luis Potosi, Dulces Nombres quicksilver deposit: Babb, 43.

Santa Maria graphite mines: Hess, 554.

Silver and copper deposits: Balarezo, 55. 
Mexico-Continued.

Economic-Continued.

Silver mines, geological formation of: Bordeaux, 125.

Sinaloa, northern: Tays, 1142.

San José de Gracia: Tays, 1143.

Sonora, El Tigre mine: Herrick, 543

La Colorado, graphite: Hess, 552.

Zacatecas district: Botsford, 130 .

Concepcion del Oro district: Chase, 221.

Zacualpam district, Mexico-Guerrero: Carpenter, 206.

Dynamic and structural.

Central plateau, origin of: Böse, 127.

Earthquakes, catalog of, 1904-1908: Aguilera, 7. in 1909: Mexico I. G., 857.

Effect of earthquakes on deep underground water circulation: Yeandle, 1296.

Fault zone in Valley of Mexico: Böse, 128.

Folding of rock strata: Nason, 890 .

Guerrero, cave of Cacahuamilpa: Urbina, 1174.

Physiographic.

Volcanoes: Inkey, 615.

Yucatan, physiographic features: Urbina, 1173.

Stratigraphic.

Guanajuato district: Botsford, 129.

Rio Nazas region: Burckhardt and Villarello, 166.

Rioverde y Arroyo Seco region: Paredes, 939.

Paleontology.

Cretaceous fossils: Aguilera, 8 .

Pliocene fauna of Tuxtepec: Böse, 127.

Williamsonias of Mixteca alta: Wieland, 1251.

Petrology.

Goneral: Aguilera, 9 .

Granodiorite of Concepcion del Oro, Zacatecas:

Mineralogy. Bergeat, 97.

Alamosite, a new lead silicate: Palache and Merwin, 931 .

Meteorite from Durango: $\Lambda \mathrm{graz}, 6$.

Underground water.

Ixmiquilpan Valley, Hidalgo: Paredes, 940.

Michoacan, Patzcuaro: Villarello, 1187.

Queretaro. Montenegro: Villarello, 1185.

Mica.

Canada: Young, 1297.

North Carolina: Pratt, 964.

South Dakota: Sterrett, 1103.

United States (general) U. S. G. S., 1170.

\section{Michigan.}

General.

Salt water in Lake mines: Lane, 730.

State geologist's report: Lane, 727 .

Economic.

Copper: Hore, 592; Odendall, 905.

Iron fields of Lake Superior region: Brinsmade, 143.

Iron mines and their mine waters: Lane, 732.

Marquette Range: Stoek; .1111.

Mine waters: Lane, 728, 729, 732.

Tuscola County, coal: Cooper; 285.

Stratigraphic.

Porcupine Mountains: Lane, 731.

Silurian formations in southern Michigan: Sherzer and Grabau, 1058.
Michigan-Continued.

Stratigraphic-Continued.

Silurian strata, nomenclature and subdivision: Lane et al., 733.

Tuscola County: Cooper, 285.

Paleontology.

Silurian faunas in southern Michigan: Sherzer and Grabau, 1058.

Underground water.

Iron mines and their mine waters: Lane, 732.

Microsauria, ancestors of the Reptilia: Moodie, 879 .

Mullstones.

New York: Newland, 894.

\section{Mine waters.}

General: Lane, 729 .

Mine waters, field assay: Lane, 728.

Michigan, salt water in Lake mines: Lane, 730

Mine explosions and earthquakes: Spalding, 1088.

\section{Mineral paints.}

New York: Newland, 894.

United States (general): U. S. G. S., 1170.

Mineral resources, 1908: U. S. G. S., 1170.

\section{Mineral waters.}

Classification: Bartow, 71:

Colorado: Headden, 533 .

Kentucky, Blue Grass region: Matson, 827.

New York: Newland, 894.

North Carolina, Pratt, 964

United States (general): U. S. G. S., 1170.

Mineralogy. (general). Sce also Meteorites and Technique. For regional see the various States. For particular minerals see list $p$. 15.9 .

Bement collection of minerals: Gratacap, 488

Benitoite: Hlawatsch, 578-580.

paragenesis and occurrence: Louderback, 781. Binary systems of alumina with silica, lime, and magnesia: Shepherd and Rankin, 1056.

Calcite crystals with new forms: Schaller, 1029.

Crystallography: Wadsworth, 1195.

Crystals, classification of: Swartz, 1126.

Diopside and its relations to calcium and magnesiumm etasilicates: Allen and White, 20 .

Enstatite and clinoenstatite: Wright, 1291; Zambonini, 1301.

Nevada, Humboldt County: Ransome, 980.

New Jersey, Newark igneous rocks: Levison, 764.

Optical mineralogy, elements of: Winchell and Winchell, 1273.

Pyrite carrying gold and galena of unusual habit: Pogue, 959.

Minerals described. See list $p .159$.

\section{Minnesota.}

General.

Franconia, geology of: Berkey, 99.

Economic.

Clays: Berkey, 100.

Iron fields of Lake Superior region: Brinsmade, 143.

Mesabi Range: Wolff, 1278.

Physiographic.

Divided lakes: Griggs' 495 
Minnesota-Continued.

Stratigraphic.

Glacial drift in Mississippl Valley: Upham, 1171.

Mesabi rocks: Winchell, 1272.

Northeastern Minnesota: Winchell, 1269.

Underground water.

Minneapolis, deep wells: Winchell, 1271.

Miocene. See Tertiary.

\section{Miscellaneous.}

First calcareous fossils: Daly, 303 .

Geologic essentials of a mine report: De Kalb, 336.

Instituto Geologico de Mexico: Aguilera, 11.

Instrumental surveying needed in practical geology: Lyman, 787.

Mining terms, definitions: Merrill, 853.

Quartz as a geologic thermometer: Wright and Larsen, 1292.

State geological survey reports on limited areas: Carney, 199.

Theory and hypothesis in geology: Lahee, 692 .

\section{Mississippl.}

Economic.

Pottery clays: Logan, 778.

Palcontology.

Echinoids from Kipley group: Slocum, 1069.

Mississippi Valley between Savanna and Davenport: Carman, 198.

Mississippian. See Carboniferous.

Missouri.

General.

State geologist's report, 1907-8: Buehler, 162.

Economic.

Joplin zine beit, migrations of: Keyes, 659 .

Lead and zinc: Buckley, 160.

Lead deposits of St. Francois and Washington counties: Buckley, 158.

Lead ores: Keyes, 658.

Mineral resources: Buehler, 162.

Ozark lead and zinc deposits: Buckley, 159; Keyes, 653.

genesis of: Keyes, 657.

Southeast Missonri lead district: Ruhl, 1022.

Tripoli deposits at Seneca: Nelson, 891.

Zinc ores: Keyes, 658.

Physiographic.

St. Francois and Washington counties: Buckley, 158.

St. Louis area: Fenneman, 392.

\section{Stratigraphic.}

Devonian of central Missouri: Greger, 491.

St. Francois and Washington counties: Buck-

Palcontology. ley, 158.

Auburn chert fauna: Branson, 139.

Fern Glen fauna: Weller, 1218, 1221.

Mineralogy.

Calcite from Joplin: Pogue, 958.

Mollusca. See also Cephalopoda, Gastropoda, and Pelecypoda.

Bibliography of post-Eocene marine of northwest coast of A merica: Dall, 301.

Caney shale fauna, Oklahoma: Girty, 457.
Mollusca-Continued.

Devonian, Montana: Raymond, 982.

Eocene deposits of Claiborne, Ala.: Wheeler, 1225 .

Lymnæa: Baker, 51 .

Maine, shells in Mud Lake: Nylander, 902.

New York, Bronx Borough, fresh-water fossils: . Humphreys, 608 .

Pliocene from Tuxtepec, Mexico: Böse, 126.

Quaternary from Greenland:.Jensen, 627.

Washington, Olympic Peninsula: Reagan, 989.

Molluscoldea. See Brachiopoda and Bryozoa.

Molybdenite.

Maine, Tunk Pond: Hills, 566.

Molybdenum.

United States (general): U. S. G. S., 1170.

Monazite.

North Carolina: Pratt, 964, 966; Pratt and Sterrett, 968 .

South Carolina: Pratt and Sterrett, 968.

United States (genera!): U. S. G. S., 1170.

\section{Montana.}

General.

Crazy Mountains: Wolff, 1279.

Geological reconnaissance: Douglass, 348 .

Economic.

Bridger coal field: Washburne, 1204.

Bull Mountain coal field: Richards, 997; Woolsey, 1288

Cement material near Havre: Pepperberg, 948.

Crazy Mountains, coal: Stone, 1115.

Custer National Forest, coal: Wegemann, 1215.

Fort Peck Indian Reservation lignite field: Smith, 1076 .

Great Falls coal field: Fisher, 396; Shurick, 1061.

Lewistown coal field: Calvert; $184,185$.

Miles City coal field: Collier and Smitn, 274.

Milk River coal field: Pepperberg, 949.

Northwestern Montana: MacDonald, 799.

Red Lodge coal field: Woodruff, 1283.

Roundup coal mines: Rowe, 1018.

Sapphire mines: Rowe, 1017.

Sentinel Butte lignite field: Leonard and Smith, 761 .

Stratigraphic.

Ceratops beds: Stanton, 1094.

Crazy Mountains, glaciation: Mansfield, 813 .

Great Falls region: Fisher, 396, 397.

Hell Creek and Ceratops beds: Knowiton, 678 .

Lewistown coal field: Calvert, 185.

Northwestern Montana: Calkins, 181.

Paleontology.

Chisternon? interpositum: Hay, 521.

Crocodile from Judith River beds: Holland, 586 .

Devonian fauna: Raymond, 982.

Procamelus from Miocene: Douglass, 347.

Ptilodus: Gidley, 448.

Petrology.

Northwestern Montana: Calkins, 181.

Philipsburg quadrangle: Calkins, 183.

Underground watcr.

Great Falls region: Fisher, 397.

Mont Pelé, condition in 1908: Hovey, 601. 


\section{Moraines.}

Alaska, Yakutat Bay region: 'Tarr, 1136.

New York, Watkins Glen-Catatonk clistrict: Williams et al., 1255.

Mount Diablo, California: Louderback, 782.

Mylostomid palatal dental plates: Eastman, 367 .

\section{Natron deposits.}

Colorado, Costilla County: Headden, 532.

Nantucket shore-lines: Gulliver, 500 .

\section{Natural gas.}

General.

Anticlinal theory of accumulation: Clapp, 231 .

Anticlinal and hydraulic theories of accumulation: Munn, 888, 889.

Geology of, in Appalachian regions: 'Bownocker, 132.

Map of productive fields, 1908: Day, 328.

Occurrence, mode of: Clapp, 232.

Canada: Ells, 372; Young, 1297.

Colorado: Lakes, 706

Illinois, Champaign County, in glacial drift: Knirk, 675.

Kansas: Haworth et al., 519 .

Louisiana, northwestern: Harris el al., 514 .

New York: Newland, 894.

North Dakota, Bottineau field: Barry, 69.

United States (genera!): U.S. G. S., 1170; Day, 327.

West Virginia, Marshall, Wetzel, and 'Tyler counties: Hennen, 537

W yoming: Lakes, 706 .

\section{Nebraska.}

Stratigraphic.

Pliocene of western Nebraska: Mathew and Cook, 840 .

Paleontology.

Agate Spring fossil quarries: Peterson, 951 .

Camel from lower Miocene: Cook, 281.

Carnivores from the Miocene: Peterson, 952.

Pliocene fauna: Matthew and Cook, 840 .

Proboscidean from the Miocene: Cook, 28 ?

Teleoceras from Miocene: Olcott, 907.

Turtles from Harrison beds: Loomis, 779 .

Nectosaurus: Moodie, 876.

Nepheline syenite of Ontario: Adams and Barlow, 4 .

Neptunite crystals from San Benito County, California: Ford, 416

Nevada.

General.

Jefferson Canyon: Packard, 924.

Economic.

Asphaltite: Anderson, 24

Bullfrog district: Tallman, 1133.

De Lamar mines, Lincoln County: Miller, 862

Ely, copper: De Kalb, 333 .

Goldfield district: Ransome, 976 .

Goldfield type of ores: Lewis, 766

Hornsilver district: Ransome, 977.

Humboldt County: Ransome, 980, 981.

Lida mining district: Root, 1015.

Lyon County, oil prospecting: Anderson, 26.

Manhattan district: Jenney, 623.

Manhattan placers, Nye County: Jones, fi35.
Nevada-Continued.

Economic-Continued.

Mason mining district, Lyon County, copper: Zehring, 1302.

Ore shoots: Chase, 220.

Petroleum: MacFarland, 80:3.

Rawhide district, Esmeralda County: Gehrmann 442; Whytock, 1245; Wolcott, 1277.

Reno region, oil prospecting: Anderson, 25

Round Mountain, Nye County: Loftus, 776; Ransome, 978.

T'onopah district: Burgess, 167; Jenney, (i?4; Johnson, 628

White Pine district: Larsh, 738

Wonder district: Ritter, 1005.

Yerington copper district: Jennings, 625; Ransome, 979 .

Zinc mines of southern Nevada: White, 1235

Physiographic.

Southwestern: Mendenhall, 845.

Stratigraphic.

Goldfield district: Ransome, 976 .

Silver Peak quadrangle: Turner, 1156.

Tonopah district: Burgess, 167.

Palcontology.

Strepsicerine antelopes: Merriam, 851.

Petrology.

Goldfield district: Ransome, 976 .

Silver Peak quadrangle: Turner, 1156.

Mineralogy.

Goldfield district: Ransome, $\mathbf{9 7 6 .}$

Humboldt County: Ransome, 980 .

Iodyrite from Tonopah: Kraus and Cook, 681 .

Leadhillite: Palache and La Forge, 930.

Meteor of 1894: Jenney, 622.

Meteorite: Jenney, 621.

Underground water.

Southwestern Nevada: Mendenhall, 845.

New Brunswick.

General.

Bathurst iron ore: Young, 1298.

Tobique County: Young, 1298.

Economic.

Bituminous shales: Ells, 374

Mining districts: Langford, 737 .

Oil shaies: Baskerville, 76 .

Phosphate deposits: Matthew, 833 .

Physiographic.

Natural history and physiography: Ganong, 435.

Stratigraphic.

Cambrian rocks, new base for: Ells, 373 .

Devonian and lower Carboniferous: Wilson, 1268.

Geological cycles in the maritime provinces: Matthew, 832 .

Paleontology.

Fish fauna of Albert shales: Lambe, 724 .

\section{Newfoundland.}

General.

Geology and mineral resources. Howley, 605 .

Economic.

Coal: Howley, 604.

Mineral resources: Howley, 605; Outerbridge, 922; Symons, 1128

Wabana submarine slopes: Chambers and Chambers, 219. 


\section{New Hampshire.}

Economic.

Copper deposits: Emmons, 378.

Granites: Villarello, 1186.

\section{New Jersey.}

General.

Administrative report, 1908: Kümmel, 683.

Philadelphia district: Bascom et al., 74 .

Trenton quadrangle: Bascom et al., 75 .

Economic.

Building stones: Lewis, 766 .

Copper: Kümmel, 686 .

Mineral industry: Kümmel, 685 .

Philadelphia district: Bascom et al., 74 .

Trenton quadrangle: Bascom et al., 75 .

Zinc deposits of Sussex County: Spencer, 1089.

Physiographic.

Manasquan Inlet changes: Kümmel, 684 .

Stratigraphic.

Geological section: Kümmel, 682 .

Highlands, geology of: Bayley, 86.

Philadelphia district: Bascom et al., 74 .

Trenton quadrangle: Bascom et al., 75.

Paleontology.

Cretaceous Bryozoa: Gregory, 494.

Mesozoic flora: Berry, 105.

Petrology.

Minerals of the Newark igneous rocks: Levison, 704.

Mineralogy.

Calcite crystals from the trap region: Whitlock, 1242.

Datolite from Bergen Hill: Ford and Pogue, 418.

Minerals of Newark igneous rocks: Levison, 764 .

Underground water.

Philadelphia district: Bascom et al, $\mathbf{7 4}$.

\section{New Mexico.}

\section{Economic.}

Black Range mining district: Wright, 1294 .

Coal mines at Dawson: Sheridan, 1057.

Copper deposits, depths at which formed: Keyes, 654.

Durango-Monero coal field: Gardner, 437.

Gallina-Raton Spring coal field: Gardner, 436.

Gallup-San Mateo coal field: Gardner, $43 \mathrm{~S}$.

Hanover iron deposits: Paige, 926.

Lake Valley silver deposits: MacDonald, 797.

Sylvanite: Jones, 636 .

Tres Hermanas district: Lindgren, 771.

Turquoise: Jones, 637.

Dynamic and structural.

Arid regions, geologic processes: Keyes, 651.

Raton coal field, metamorphosed coal: Lee, 746 .

Origin of certain depressions in the Sandias: Reagan, 990.

Physiographic.

Arid region, formations of: Keyes, 651.0

Base-level of eolian erosion: Keyes, 655 .

Stratigraphic.

Manzano group of the Rio Grande Valley: Lee, 745 .

Ortiz Mountains: Keyes, 654.

Raton coal field: Lee, 747 .

Raton coal field, unconformity in: Lee, 744,748 .

Tuertos Mountains: Keyes, 654 .
New Mexico-Continued.

Paleontology.

Manzano group of Rio Grande valley: Girty, 458.

Mineralogy.

Calamine crystals from the Organ Mountains: Ford and Ward, 419.

Calcite crystals: Schaller, 1029.

\section{New York.}

General.

Director's report, 1908: Clarke, 240.

Geological maps: Leighton, 755 .

Inliers, types of: Ruedemann, 1019.

New York City: Cratacap, 487.

Watkins Glen-Catatonk district: Williams et al., 1255

Economic.

Brewster iron-bearing district: Koeberlin, (i79.

Clinton ores: Newland, 892.

Mining and quarry industry, 1908: Newland, 894.

Watkins Glen-Catatonk district: Williams $e$ al., 1255.

Dynamic and structural.

Dikes in the Hamilton shale near Clintonville: Smith, 1073

Landslip in Hudson River clays: Newland, 893.

Physiographic.

Champlain coast lines: Hudson, 606 .

Drainage evolution in central New York: Fairchild, 389.

Hudson River channel: Hovey, 602; Kemp, 646.

Manhattan Island and East River channel: Berkey, 102.

Moravia quadrangle: Carney, 203.

Palisades of the Hudson: Hall, 504

Preglacial valleys in eastern New York: Cook, 283.

Tertiary drainage problems: Grabau, $\mathbf{4 7 3}$

Watkins Glen: Tarr, 1135.

Watkins Glen-Catatonk district: Williams $e t$ al., 1255 .

Stratigraphic.

A dirondacks, ice movement and erosion: Miller, 868

Pleistocene geology: Miller, 869 .

Brewster iron-bearing district: Koeberlin, 679.

Crystallines of southeastern New York: Berkey, 103.

Dutchess County: Gordon, 464

Geneva-Ovid quadrangles: Luther, 786.

Glacial waters west and south of the Adirondacks: Fairchild, 388.

Glaciation, multiple: Fairchild, $3 \mathbf{s i}$.

Hudsonian and Ontarian glacier lobes: Fairchild, 387

Manhattan Island: Berkey, 101.

Moravia quadrangle, Pleistocene geology: Carney, 203.

New York City, geology: Gratacap, 487.

Remsen quadrangle: Miller, 867.

Silurian strata, nomenclature and subdivision: Lane et al., 733 .

Watkins Glen-Catatonk district: Williams et al., 1255. 
New York-Continued.

Paleontology.

Algæ from Trenton limestone: Ruedemann, 1020.

Araucariopitys: Jeffrey, 617 .

Cretaceous coniferous remains from Kreischerville: Hollick and Jeffrey, 588 .

Dinichthyid armor plates from Marcellus shale: Smith, 1072.

Fresh-water fossils from Bronx Borough, New York City: Humphreys, 608.

Watkins Glen-Catatonk district: Williams al., 1255.

New York City, geology of: Berkey, 101.

\section{Nicaragua.}

Economic.

Matagalpa district: West, 1223.

Nickel.

Canada: Young, 1297.

Ontario, Sudbury: Ontario B. M., 909.

Quebec: Dresser, 361 .

United States (general): U. S. G. S., 1170.

Nomenclature. See also Stratigraphic.

Dip, pitch, hade: Wilson, 1264.

Geologic names, status of: Keith, 642 .

Geologic terms, definitions: Wood, 1281.

Geological terms: Grabau, 474.

Nontronite: Bergeat, 98.

\section{North Carolina.}

General.

Bibliography of geology, mineralogy, and geography: Laney and Wood, 736.

State geologist's biennial report: Pratt, 963,965 .

Economic.

Gold Hill copper district: Laney, 735.

Gold mining: Lyon, 788.

Mineral production in 1908: Pratt, 967.

Mineral waters: Pratt, 904.

Mining industry in 1907: Pratt, 964.

Monazite: Pratt, 966; Pratt and Sterrett, 968.

Peat deposits: Davis, 314.

Placer mining industry: Welch, 1216.

Tin deposits: Ball, 59

Stratigraphic.

Cretaceous geology: Stephenson, 1098.

Davidson County: Pogue, 960.

Tertiary erosion intervals: Miller, 860 .

Palcontology.

Cretaceous floras: Berry, 109.

Pleistocene flora: Berry, 107.

Pelrology.

Granites of Chapel Hill: Eaton, 368 .

Volcanic .rocks of Davidson County: Pogue, 960 .

\section{North Dakota.}

General.

Geological reconnaissance: Douglass, 348 .

Geological survey report: L,eonard, 757, 760 .

Jamestown-Tower district: Willard, 1253.

Economic.

Bottineau gas field: Barry, 69 .

Cement materials of northeastern North Dakota: Barry and Melsted, 70.

Fort Berthold Indian Reservation lignite field: Smith, 1075
North Dakota - Continued.

Economic-Continued.

Sentinel Butte lignite field: Leonard and Smith, 761 .

Southwestern North Dakota: Leonard, 758.

Washburn lignite field: Smith, 1074.

Physiographic.

Northeastern North Dakota: Barry and Melsted, 70 .

Southwestern North Dakota: Leonard, 758.

Stratigraphic.

Geological history: Leonard, 759 .

Hell Creek and Ceratops beds: Knowlton, 678 .

Jamestown-Tower district: Willard, 1253.

Northeastern North Dakota: Barry and Melsted, 70 .

Southwestern North Dakota: Leonard, 758.

Underground water.

Jamestown-Tower district: Willard, 1253.

Northeastern North Dakota: Barry and Melsted, 70 .

Northwest Territories.

General.

Hudson Bay coast: O'Sullivan, 920 .

Pelly River basin: Keele, 641 .

\section{Nova Scotia.}

General.

Cumberland County: Fletcher, 405.

Volcanic bombs from near Lake Ainslie: Poole, 961.

Economic.

Auriferous antimony ore of West Gore: Haley, 503.

Bituminous shales: Ells, 374.

Guysborough County, Richardson mine: Brown, 154

Gypsum on Cape Breton Island: Tyssowski, 1160.

Iron ore deposits: Woodman, 1282.

Kings and Lunenburg counties: Faribault, 390 .

Leipsigate gold mining district: Moore, 885 .

Mining districts: I,angford, 737.

South Cheticamp, Cape Breton Island, ore deposits: Grandin, 481.

Stratigraphic.

Carboniferous, Northumberland County: Fletcher, 404.

Cumberland County: Poole, 962.

Geological cycles in the maritime provinces:

Matthew, 832 .

Joggins section: Logan, 777 .

Silurian section at Arisaig: 'Twenholel, 1158.

Paleontology.

Dictyonema websteri: Ruedemann, 1021.

Silurian section at $A$ risaig: Twenhofel, $115 \mathrm{~S}$.

Nunataks: Tarr, 1136.

Ohio.

Dynamic and structural.

Landslide accompanied by buckling: Van Horn, 1180 .

Physiographic.

Ohio, Licking County: Scheffel, 1032.

Licking County, Mary Ann township: Carney, 200.

bicking Narrows at Black Hand: Mather, $\$ 24$.

Raised beaches of Berea, Cleveland, and Euclid sheets: Carney, 202. 
Ohlo-Continued.

\section{Stratigraphic.}

Conemaugh formation: Condit, 280 .

Devonian, middle: Stauffer, 1096.

Kelleys Island, glacial erosion on: Carney, 205

Licking County, Mary Ann township: Carney, 200.

Richmond near Oxford: Shideler, 1059.

Silurian strata, nomenclature and subdivision:

Paleontology. Lane et al., 733

Cincinnatian and Lexington fossils: Foerste, 413.

Cincinnatian fossils: Foerste, 412.

Dinichthyids from northern Obio: Branson, 140.

Richmond near Oxford: Shideler, 1059.

Silurian fossils: Foerste, 409.

Mineralogy.

Calcite crystals from Kelleys Island: Ford and Pogue, 417.

Oil. See Petroleum.

oil shales.

Canada: Young, 1297.

New Brunswick: Baskerville, 77.

Nova Scotia and New Brunswick: Ells, 373.

\section{Oklahoma.}

\section{Economic.}

Asphalt deposits: Gould, 468,469 .

Coal: Gould, 470.

Grahamite: Taff, 1130.

Gypsum deposits: Gould, 467.

Madill oil pool: Taff and Reed, 1132.

Petroleum analyses: Day, 330 .

Stratigraphic.

Anthracolithic rocks of Kansas and Oklahoma: Beede, 91.

Bowlder deposits in mid-Carboniferous marine shales: Taff, 1131.

Caney shale: Girty, 457.

Marion stage formations: Beede, 90 .

Paleontology.

Caney shale fauna: Girty, 457.

Oligocene. See Tertiary.

Ontario.

General.

Algoma and Thunder Bay districts: Wilson, 1267.

Index to reports of Bureau of Mines: Nicolas, 899.

Lake $\Lambda$ bitibi area: Baker, 52 .

Lake Nipigon region, Thunder Bay district: Wilson, 1263.

Lake Nipigon-Clay Lake region: Collins, 277.

Lake Superior region: Collins, 278.

Onaman iron range: Moore, 883 .

Simcoe sheet: Johnston, 633 .

Economic.

Black Sturgeon iron region: Coleman, 267.

Bog iron on English River: Moore, 882.

Bureau of Mines, eighteenth report: Gibson, 447.

Clays: Baker, 53, 54; Coleman, 270.

Cobalt district: Anderson, 23; Higgins, 557 .

Cobalt and Sudbury: Ontario B. M., 909.

Cobalt-silver deposits, origin: Hore, 591 ,
Ontario-Continued.

Economic-Continued.

Feldspar: Morsack, 886.

Gowganda district: Collins, 276; West, 1222 .

Gowganda and Miller lakes silver area: Burrows, 169

Iron fields of Lake Superior region: Brinsmade, 143.

Iron formation of Woman River area: Allen, 17. Iron range north of Round Lake: Moore, 881 .

Lake Abitibi area: Baker, 52 .

Lake Wendigokan region: Moore, 884 .

Maple Mountain district: Ramsay, 975.

Mining districts: I.angford, 737 .

Montreal River district: Barlow, 64; Collins, 279; Tyrrell, 1159.

Nipigon iron ranges: Coleman, 266.

Onaman iron range: Moore, 883 .

Rainy River district: Fleming, 403.

Silver Islet, Lake Superior: McDermott, 795 , 796.

South Lorraine silver area: Burrows, 170; Phillips, 953 .

Sudbury ores: Hixon, 576 .

Thunder Bay and Rainy River districts: Hille, 564.

Physiographic.

Lake Huron region: Goldthwait, 462.

Lake Ojibway, last of glacial lakes: Coleman, 268.

Stratigraphic.

Algonquin and Ninissing shore lines: Goldthwait and Jacobson, 463.

Drift deposits, classification, and nomenclature: Coleman, 269.

Glacial Lake Ojibway: Coleman, 268.

Gowganda district: Collins, 276.

Grenville-Hastings unconformity: Miller and Knight, 866

Lake Nipigon region: Wilson, 1262.

Lake Nipigon-Clay Lake region: Collins, 277.

Lake Wendigokan region: Moore, 884 .

Montreal River district: Collins, 279.

Pleistocene deposits of -southwestern Ontario: Taylor, 1140.

Simcoe sheet: Johnston, 633.

\section{Paleontology.}

Cambro-Silurian and Silurian fossils from Albany River region: Whiteaves, 1240 .

Graptolites of the Niagaran dolomite: Bassler, 79.

Periglyptocrinus priscus: Parks, 942.

Protaster: Parks, 941.

Petrology.

A mphibolites of the Laurentian area: Adams, 2.

Gowganda district: Collins, 276.

Lake Nipigon-Clay Lake region: .Collins, 277.

Nepheline and associated syenites: Adams and Barlow, 4.

Onaman iron range: Moore, 883.

Mineralogy.

Hastingsite from Dungannon: Graham, 480.

Onyz.

Mexico, Oaxaca, Tehuantepec district: Flores, 408.

Opisthias rarus: Gilmore, 454. 


\section{Ordovician.}

General.

Classification of: Grabau, $\mathbf{4 7 1 .}$

Evolution of North America: Grabau, 472.

Paleogeographic map: Willis, 1256.

Paleogeography: Ulrich, 1165.

Stratigraphy.

Arkansas: Purdue, 972.

Ouachita area: Purdue, 973 .

Canada, maritime provinces: Matthew, 832 .

Georgia: Veatch, 1184.

Illinois, Alexander County: Savage, 1027.

northwestern: Carman, 198.

Iowa, eastern: Carman, 198.

Kentucky, Blue Grass region: Matson, 827 .

Missouri, Auburn chert fauna: Branson, 139. southeastern: Buckley, 158.

Nevada, Silver Peak quarlrangle: Turner, 1156.

New Jersey, Kümmel, 682.

Ohio, Richmond near Oxford: Shideler, 1059.

Ontario, Albany River region: Whiteaves, 1240.

Simcoe sheet: Johnston, 633.

Pennsylvania, Lehigh Valley: Wherry, 1229.

Medina: Grabau, 476.

Mercersburg-Chambersburg district: Stose, 1119.

Philadelphia district: Bascom et al., 74 .

South Dakota: Darton, 307.

Black Hills region: Darton, $306,310$.

'T'exas, El Paso quadrangle: Richardson, 998.

Virginia, western: Bassler, 78.

Wyoming, Black Fills region: Darton, 306 .

Paleontology.

Alga from Trenton of New York: Ruedemann, 1020 .

Brachiopoda of Richmond group: Foerste, 414.

Cincinnatian and Lexington fossils: Foerste, 413.

Cincinnatian fossils: Foerste, 412.

Fish remains in Ordovician of Black Hills: Darton, 310

Nettleroth collection: Bassler, 80 .

Ohio, Richmond near Oxford: Shideler, 1059.

Periglyptocrinus priscus: Parks, 942.

Protaster: Parks, 941.

Virginia, western: Bassler, 78.

Ore deposits, origin. For ore deposits in general, see Economic (general).

General: Butler, 176; Marrs, 815; Thomas and MacAlister, 1144.

Association of ores and country rock: Surr, 1124.

Cave ores: Lakes, 718 .

Centers of mineralization: Iakes, 700 .

Distribution of metals and minerals in ore shoots: Surr, 1123.

Formation and enrichment of ore-bearing veins: Bancroft, 61,62 .

Intersection, faulting, and movements in veins: Lakes, 701.

Locus of vadose ore deposition: Keyes, (i.58.

Magmatic waters and volcanic action: Hixon, 574.

Metallogenetic epochs: Lindgren, 773.

Metamorphosed ore deposits: Emmons, 378.

Modern ancient volcanoes and ore deposits: Lakes, 716.
Ore deposits, origin-Continued.

General-Continued.

Nuggets, origin: Lakes, 704.

Occurrence of ore deposits in mineral belts: Lakes, 717.

Occurrences of ore in veins: Lakes, 714.

Ore deposition, development of theories of: Emmons, 377.

Ore shoots: Lindgren, 769 .

Ores formed by magmatic segregation: Garrison, 439.

Ores in volcanic craters and fumarole orifices: Lakes, 715.

Outerop of ore bodies: Emmons, 379; Min. and Sci. Press, 871

Volcanic action and ore deposition: Chase, 222; Hixon, 577.

Cobalt-silver deposits of northern Ontario: Hore, 591.

Colorado, Aspen ore deposits: I.oughlin, 783; Spurr, 1092.

Copper, garnet contact deposits, depths at which formed: Keyes, 654 .

Michigan: Lane, 729.

New England: Emmons, 379.

Gold, alluvial: Lakes, 703 .

Georgia: Jones, 638.

Goldfield district, Nevada: Ransome, 976.

Iron: Grimsley, 496 .

bog ore, Ontario: Moore, 882.

Clinton ore, New York: Newland, 892.

Clinton ores, Pennsylvania: Kelly, 643 .

Georgia, manganese ore: Watson, 1210.

Michigan: Lane, 732 .

Ontario, Onaman range: Moore, 883 .

Woman River area: Allen, 17.

New York, Brewster district: Koeberlin, 679.

Residual brown ores of Cuba: Weld, 1217.

Lead and zinc of Ozark region: Buckley, 159; Keyes, 653.

Lead, Missouri, southeastern: Buckley, 158.

Manganese ores: West, 1223.

Massachusetts, Newburyport, silver-lead deposits: Clapp and Ball, 229.

Nevada, ore shoots: Chase, 220.

Ozark lead-zinc deposits: Keyes, 657.

Salt deposits, West Virginia: Grimsley, 496.

Silver, Colorado, Aspen: Spurr, 1092.

Lake Valley, New Mexico: MacDonald, 797.

Silver Islet vein, Lake Superior: McDermott, 796 .

Sudbury ores: Hixon, 576 .

Tungsten, Colorado: George, 443.

Tungsten deposits and surface enrichment: Surr, 1122.

Wisconsin, brown ores: Allen, 16.

Oregon.

General.

Prehistoric Siskiyou Island and Marble Halls: Watson, 1208.

Economic.

Bohemia mining district: MacDonald, 798 .

Cracker Creek district, Baker County: Pärdee, 937.

Grants Pass: Diller and Kay, 340 .

Rogue River valley coal field: Diller, 339 .

Rye Valley gold mines: Mathez, 826 . 
Oregon-Continued.

Economic-Continued.

Structural materials: Darton, 308.

Waldo, placers: Nicol. 898.

Willow Creek, Morrow County, coal prospect: Mendenhall, 849

Dynamic and structural.

Cracker Creek gold district, Baker County, faulting and vein structure: Pardee, 937.

Physiographic.

Harney Basin region: Waring, 1202.

Stratigraphic.

Applegate region: Diller and Kay, 340 .

Grants Pass region: Diller and Kay, 340.

Harney Basin region: Waring, 1202.

Miocene of Astoria and Coos Bay: Dall, 300.

Tertiary: Arnold, 32.

Paleontology.

Miocene of Astoria and Coos Bay: Dall, 300.

Sea lion from Miocene: True, 1154 .

Underground water.

Harney Basin region: Waring, 1202.

Origination of self-generating matter and the influence of aridity upon its evolutionary development: Macdougal, 800 .

Orogeny.

Great Basin ranges, erosional origin of: Keyes 652 .

Oscillation. See Changes of level.

Ostracoda. See also Crustacea.

Caney shale fauna, Oklahoma: Girty, 457.

Silurian fossils from Indiana, Ohio, and Kentucky: Foerste, 409.

Oxydactylus campestris: Cook, 281.

Ozokerite.

Utah: MacFarren, 806.

Pacific Coast Tertiary faunas: Arnold, 32.

Paints. See Mineral paints.

\section{Paleobotany.}

Algæ from Trenton limestone of New York: Ruedemann, 1020.

Amber in Laramie Cretaceous: Cockerell, 263.

Araucariopitys: Jeffrey, 617.

Colorado, Fagopsis from Florissant: Hollick, 587.

Cretaceous floras of Virginia and North Carolina: Berry, 109.

Cretaceous coniferous remains from New York: Hollick and Jeffrey, 588.

Euphorbiaceæ: Cockerell, 262.

Firmianites aterrimus: Cockerell, 259.

Florissant plants: Cockerell, 264.

Kansas, upper Paleozoic plants: Sellards; 1045.

Mesozoic flora of A tlantic coastal plain: Berry, 105.

North Carolina, Pleistocene flora: Berry, 107.

Paleozoic floras: White, 1231.

Structure of leaf in Cretaceous pines: Jeffrey, 618.

Virginia, Miocene flora: Berry, 104.

Pleistocene swamp deposits: Berry, 108.

Williamsonias of Mixteca alta, Mexico: Wieland, 1251.
Paleoclimatology.

General: Bustamante, 172

Greenland: Jensen, 627.

Manson's theory of geological climates: Reid, 991.

Paleozoic: White, 1231.

Pleistocene conditions: Salisbury, 1024.

Paleogeographic maps.

Arizona and southern California in post-Pliocene: Blake, 1201.

Devonian, Columbus time: Stauffer, 1096.

Delaware-Olentangy time: Stauffer, 1096.

North America, Cambrian to Quaternary: Willis, 1256 .

Ordovicic, Siluric, and Devonic: Grabau, 472 .

Pacific Coast Tertiary: Arnold, 32.

Paleogeography. See also Geologic history, Paleoclimatology, and Paleogeographic maps.

Cambrian faunas, evolution of: Walcott, 1198.

Carboniferous: Girty, 455.

Devonian and Mississippian faunas: Weller, 1219.

Early vertebrate faunas: Williston, 1259 .

Mesozoic of North America: Stanton, 1094.

New York: Clarke, 240.

North America: Schuchert, 1036.

Ordovician: Ulrich, 1165.

Ordovicic, Siluric, and early Devonic: Grabau, 472.

Principles controlling restorations: Willis, 1256.

Richmond group: Foerste, 414.

Paleontology (general). See also the classes of animals and Paleobotany. For stratigraphic see the different systems. For regional see the various States.

General: Woodward, 1286.

American paleontology and Neo-Lamarckism: Case, 211.

Cambrian faunas, evolution of: Walcott, 1198.

Devonian and Mississippian faunas: Weller, 1219.

First calcareous fossils: Daly, 303.

Laboratory methods in vertebrate paleontology: Hermann, 541.

Ordovicic, Siluric, and Devonic faunas: Grabau, 472 .

Paleozoic, revised classification of: Grabau, 471.

Paragenesis of minerals.

Copper deposits, Latouche Island, Alaska: Lincoln, 768 .

Peat.

General.

Origin: Davis, 317

Alaska: Davis, 315.

Canada: Nyström and Anrep, 903.

Florida: Sellards, 1049.

Indiana: Taylor, 1139 .

Iowa: Beyer, 112.

bibliography of peat: Lees, 753 .

Maine: Bastin and Davis, 83.

New York: Newland, 894.

North Carolina: Davis, 314.

United States: Davis, 316; U. S. G. S., 1170.

Pegmatite in granite of Massachusetts: Warren, $\cdot 1203$.

$56693^{\circ}-$ Bull. $444-10-10$ 
Pelecypoda. See also Mollusca.

Auburn chert fauna, Missouri: Branson, 139.

California, Coalinga district, Cretaceous and Tertiary: Arnold, 31.

Silurian of Tennessee, Indiana, and Kentucky: Foerste, 411.

\section{Pennsylvania.}

General.

Mercersburg-Chambersburg district: Stose, 1119 .

Philadelphia district: Bascom et al., 74.

Trenton quadrangle: Bascoin et al., 75 .

Economic.

Anthracite at Wilkesbarre: Cist, 227.

Clinton iron-ore deposits of Stone Valley: Kelly, 643.

Ganister in Blair County: Butts, 177.

Oil and gas accumulation: Clapp, 231; Munn, 888.

Mercersburg-Chambersburg district: Stose, 1119.

Philadelphia district: Bascom et al., 74 .

Trenton quadrangle: Bascom et al., 75 .

Physiographic.

Drainage evolution: Fairchild, 389 .

Mercersburg-Chambersburg district: Stose,1119.

Preglacial drainage of western Texas: Hice, 555 .

Stratigraphic.

Bloomsburg iron ore, stratigraphic position of: Van Ingen, 1181.

Cambrian of Lancaster County: Roddy, 1008

Conemaugh sections: Raymond, 983.

LehighrValley district, early Paleozoic: Wherry, 1229.

Medina and Shawangunk: Grabau, 476 .

Mercersburg-Chambersburg district: Stose, 1119 .

Philadelphia district: Bascom et al., 74.

Pre-Cambrian gneisses of Piedmont plateau: Bascom, 73.

Shawnee Mountain, glaciated rock: Corss, 286.

Trenton quadrangle: Bascom et al., 75 .

Paleontology.

Cambrian of Lancaster County: Roddy, 1008.

Devonian and Mississippian fossils near Meadville: Millward, 870

Glacial drift fossils: Millward, 870.

Helodus, n. sp., Eastman, 365.

Marine fossils, new horizons for: Raymond, 984 .

Mineralogy.

Carnotite: Wherry, 1227 .

Underground water.

Philadelphia district: Bascom et al., 74 .

Pennsylvanian. See Carboniferous.

Pentremites. See Blastoidea.

Permian. See Carboniferous.

\section{Petroleum.}

General: Wheeler, 1224.

Anticlinal and hydraulic theories of accumulation: Munn, 888, 889.

Anticlinal theory of accumulation: Clapp, 231. Genesis: Coste, 287,288; Dalton, 302; Lakes, 705, 709, 713; Min. and Sci. Press, 871.

Magnetic disturbances and the genesis of petroleum: Becker, 89 .

Map of productive fields, 1908: Day, 328 .

Occurrence, mode of: Clapp, 232.

California, Coalinga district: Forstner, 420,422.

Los Angeles: Barbour, 63.
. Petroleum-Continued.

Canada: Ells, 372; Young, 1297.

Colorado: Lakes, 696 . -

Boulder field: Washburne, 1205.

Florence field: Washburne, 1206 .

Illinois: Bain, 48; Wheeler, 1224.

eastern: Blatchley, 122 .

Kansas: Haworth et al, 519 .

analyses: Day, 330 .

Louisiana, northwestern: Harris et al., 514 .

Mexico: Day, 329; Villarello, 1189,1190.

Dos Bocas: Villarello, 1188.

Nevada: MacFarland, 803.

Lyon County, prospecting: Anderson, 26.

Reno region, prospecting: Anderson, 25.

New York: Newland, 894

Oklahoma, analyses: Day, 330 .

Madill pool: Taff and Reed, 1132.

United States (general): U.S. G. S., 1170; Day, 326.

Utah: Rogers, 1011.

Green River fields in Wayne County: Peet, 945.

West Virginia, Marshall, Wetzel, and Tỷer counties: Hennen, 537.

Petrology (general). See also Igneous and volcanic rocks, and Technique. For regional, see the various States. For rocks described see $p .160$.

Chemical composition as a criterion in identifying metamorphosed sediments: Bastin, 82.

Igneous rocks, general: Iddings, 611.

classification: Waitz, 1197.

Magnetic rocks: Harris, 513 .

Microstructure of ore from Frisco mine, Idaho: Campbell, 192.

Scapolite, primary, in igneous rocks: Calkins, 183.

Philadelphia folio: Bascom et al., 74 .

Philosophy. See also History.

Meteorites with reference to world-making: Merrill, 856.

\section{Phosphate.}

Florida: Sellards, 1049; Stone, 1114; Van Horn, 1179 .

New Brunswick: Matthew, 833 .

South Carolina: Matthew, 833; Van Horn, 1179 Tennessee: Van Horn, 1179.

United States (general): U. S. G. S., 1170; Van Horn, 1179

Utah: Van Horn, 1179.

Wyoming: Van Horn, 1179.

Physiographic (general). For regional, see the various States. See also Drainage changes.

A ppalachian Mountain system, physiographic subdivisions: Davis, 323 .

College unit in physical geography; Marbut, 814 .

Colorado Canyon: Davis, 324 .

Convexity of hilltops: Gilbert, 451 .

Description of land forms: Davis, 322.

Desert, lineaments of: Keyes, 661:

Desert ranges, wind action on; Keyes, 654 .

Earth's plan: Taylor, 1141.

Geographical essays: Davis, 318. 
Physiographic-Continued.

Geography at the University of Wisconsin: Martin, 822 .

- Hanging valleys: Johnson, 630 .

High-school course in physiography: Fairbanks, 384.

Intercision, a drainage modification: Goldthwait, 460.

Laboratories for physical geography: Wright, 1289.

Laboratory for physiography: Stearns, 1097.

Laboratory for topographic work: Mead and Martin, 843.

Laboratory manual in physical geography: Hopkins and Clark, 590.

Laboratory methods for geography: Hobbs, 584 .

Laramie region: Blackwelder, 117 .

North $\Lambda$ merica and Europe: Penck, 946 .

Physical geography in the secondary school: Fenneman, 393.

Physiography: Fairbanks, 384.

Relation of geology to topography: Martin, 820 .

Striations and $U$-shaped valleys not produced by glacial action: Hovey, 593 .

Volcanic topography: Smith, 1078.

Pisces.

Arthrodira: Hussakof, 609 .

Carcharodon: Dean, 332 .

Devonian of Ohio: Stauffer, 1096.

Dinichthyid armor plates from Marcellus shale of New York: Smith, 1072.

Dinichthyids from northern Ohio: Branson, 140.

Fish remains in Black Hills Ordovician: Darton, 310 .

Gar-pike from Utah: Cockerell, 260.

Giant of ancient sharks: Dean, 332.

Helodus, 'new species, from Pennsylvania: Eastman, 365.

Miocene drumfish, Pogonias multidentatus: Smith, 1071.

Mylostomid dental plates: Eastman, 366,367 .

New Brunswick, Albert shales: Lambe, 724.

Sharks, chimæroids, and arthrodires: Dean, 331.

Pitchblende: Fleck, 402; Zalinski, 1300.

Placers. See also Gold.

Alaska: Brooks, 148

Fortymile quadrangle: Prindle, 969 .

Alluvial deposits, origin, character, and distribution: Lakes, 703 .

Alluvial gold: Garrison, 440 .

Arizona, Calizona: Hedburg, 534.

Occurrence of gold in placers: Collins, 275.

Plants. See Paleobotany.

Platinum.

United States (general): U. S. G. S., 1170.

Pleistocene. See Quaternary and Glacial geology.

Pliocene. See Tertiary.

Polyzoa. See Bryozoa.

Portland cement. See Cement.

Porto Rico.

Tron and copper deposits: Hamilton, 505.
Pre-Cambrian.

General: Van Hise and Leith, 1178.

Grenville-Hastings unconformity: Miller and Knight, 866.

\section{Correlation.}

Basis of pre-Cambrian correlation: Adams, 3.

Classification and correlation: Van Hise, 1177.

Stratigraphy.

Canada: Miller, 865 .

maritime provinces: Matthew, 832 .

Colorado, Hahns Peak region, Routt County George and Crawford, 446.

north central: Henderson, 536 .

Greenland: Nordenskjöld, 900.

Idaho, northern: Calkins, 181.

Missouri, southeastern: Buckley, 158.

Montana, north western: Calkins, 181 .

Nevada, Silver Peak quadrangle: Turner, 1156.

New Brunswick, Saint John: Ells, 373.

New Jersey: Kümmel, 682 .

Trenton quadrangle: Bascom et al., 75.

New York and adjoining States: Gordon, 464.

New York, Remsen quadrangle: Miller, 867.

North America: Van Hise and Leith, 1178.

Ontario, Algoma and Thunder Bay districts: Wilson, 1267.

Gowganda and Miller lakes area: Burrows, 169.

Gowganda district: Collins, 276 .

Lake Abitibi area: Baker, 52 .

Lake Nipigon-Clay Lake region: Collins, 277.

Lake Superior region: Collins, 278.

Lake Wendigokan region: Moore, 884.

Montreal River district: Collins, 279.

Onaman area: Moore, 883.

South Lorraine area: Burrows, 170.

Pennsylvania, Mercersburg-Chambersburg district: Stose, 1119.

Philadelphia district: Bascom et al., 74 .

Trenton quadrangle: Bascom ct al., 75 .

South Dakota: Darton, 307:

A berdeen-Redfield district: Todd, 1146.

Black Hills region: Darton, 306.

Texas, El Paso quadrangle: Richardson, 998.

Wyoming, Black Hills region; Darton, 306 .

Pre-Cambrian glaciation: Knight, 674 .

Precious stones. See alsa Diamonds, Sapphires, and Turquoise.

Geological distribution and mode of occurrence in North America: Lakes, 711

North Carolina: Pratt, 964.

United States (general): U. S. G. S., 1170.

Primates. See Mammalia.

Protaster: Parks, 941.

Protostegidæ: Wieland, 1249:

Pseudomorphism.

Massachusetts, Hampden County: Roe, 1009.

Nontronite after wollastonite: Bergeat, 98 .

Pyrite.

New York: Newland, 894.

Ontario, Lake Nipigon-Clay Lake region: Collins, 277.

United States (general): U. S. G. S., 1170.

Quartz.

North Carolina: Pratt, 964.

United States (general): U. S. G. S., 1170. 
Quartz as a geologic thermometer: Wright and Larsen, 1292.

Quaternary. See also Glacial geology. General.

Paleogeographic map: Willis, 1256.

Pleistocene physical geography: Salisbury, 1024.

Stratigraphy.

Alaska, Fortymile quadrangle: Prindle, 969.

California: Arnold, 31 .

McKittrick-Sunset district: Johnson, 631.

Santa Cruz quadrangle: Branner et al., 138.

Colorado, Hahns Peak region, Routt County: George and Crawford, 446.

Leadville quadrangle: Capps, 196.

Delaware, Philadelphia district: Bascom et al., 74.

Florida: Matson and Clapp, 829.

southern: Sanford, 1025.

Georgia: Veatch, 1184.

Illinois, northwestern: Carman, 198.

Iowa, eastern: Carman, 198.

Kentucky, Blue Grass region: Matson, 827.

Mexico, Baja California: Wittich, 1276.

Montana, Great Falls region: Fisher, 396, 397.

Lewistown field: Calvert, 185.

Nevada, Silver Peak quadrangle: Turner, 1156.

New Jersey, Philadelphia district: Bascom $c t$ al., 74 .

Trenton quadrangle: Bascom et ot., 75 .

Pennsylvania, Philadelphia district: Bascom et al., 74 .

Trenton quadrangle: Bascom et al., 75.

South Dakota, Aberdeen-Redfield district: Todd, 1146.

Belle Fourche quadrangle: Darton and O'Harra, 312.

Texas, El Paso quadrangle: Richardson, 998.

Utah, Uinta and Wasatch Mountains: Atwood, 40.

Paleontology.

Aftonian mammalian fauna: Calvin, 1.88 .

California, cat allied to Felis atrox: Merriam, 850.

peacock from Quaternary asphalt beds: Miller, 863.

Teratornis from Rancho La Brea: Miller, 864.

Distribution of Pleistocene Mammalia: Hay, 524.

Greenland, Mollusca: Jensen, 627.

Mammal horizons of western North America: Osborn, 913.

Maryland, Juglandaceæ from Pleistocene: Berry, 106.

North Carolina, Pleistocene flora: Berry, 107.

Ophiuroids in glacial clay of Maine coast: Sayles, 1028.

Quebec.

General.

Geological reconnaissance: Dresser, 357.

Labrador Peninsula: Valiquette, 1176.

Lake Chibougamau region: Dulieux, 362 .

Lake Opasatika and the Height of Land: Wilson, 1266.

Laurentian Highlands: Laflamme, 689.

Notre Dame and Shickshock Mountains: Laflamme, 688 .
Quebec-Continued.

Economic.

Asbestos deposits: Dresser, 359, 360 .

Chrome iron deposits: Cirkel, 224.

Graphite: Brumell, 157.

Iron ore deposits along Ottawa and Gatineau rivers: Cirkel, 223.

Mineral deposits of serpentine belt: Dresser, 361 .

Mining districts: Langford, 737.

Mining operations for 1908: Obalski, 904.

Opasatika Lake district: Cirkel, 225.

Riviere Du Loup gold fields: Hind, 569.

Petrology.

Monteregian Hills, rock type from: Dresser, 358 .

Quicksilver.

Canada: Young, 1297.

Mexico, San Luis Potosi, Dulces Nombres deposit: $\mathrm{Babb}, 43$.

Texas: Phillips, 954.

Brewster County: Dinsmore, 343.

United States (general): U. S. G. S., 1170.

Radioactivity of the thermal waters of Yellowstone National Park: Schlundt and Moore, 1033.

Rare earths.

Colorado: Fleck, 401

Rare metals: Dickinson, 338.

United States (general): U. S. G. S., 1170.

Recent.

Paleontology.

Fresh-water fossils from Bronx Borough, New York City: Humphreys, 608.

I.ymnæa, new species: Baker, 51 .

Shells, fossil and living, in Little Mud Lake: Nylander, 902.

Rolief maps.

A laska: Brooks, 148.

Malaspina glacier region: Martin, 821.

Reptilla.

General: Moodie, 876 .

Camptosaurus from Jurassic, osteology of: Giimore, 453.

Cotylosauria and Nectosaurus: Moodie, 876.

Crocodile from Judith River beds of Montana: Holland, 586.

Dinosaur from Kansas chalk: Sternberg, 1101.

Dinosaur societies: Lull, 785; Williston, 1261.

Dinosauria, classification and phylogeny: Huene, 607.

Dinosaurs from Jurassic of Greenland: Fraas, 423.

Iguanodont dinosaur, epidermis of: Osborn, 914.

Iguanodont dinosaurs from upper Cretaceous: Osborn, 917.

Leatherback turtle from Miocene of Maryland: Palmer, 936.

Microsauria, ancestors of Reptilia: Moodie, 879 .

Oldest land reptiles: Matthew, 837.

Protostegidæ, revision of: Wieland, 1249.

R hynchocephalian reptile from Jurassic of $\mathrm{W}_{\mathrm{yo}}$ ming: Gilmore, 454.

Saurian from the Niobrara: Wieland, 1250.

Toxochelys and Chisternon: Hay, 521.

Trachodon from the Laramie beds of W yoming, Sternberg, 1099. 
Reptilia-Continued

Trachodon skeleton: Osborn, 915 .

Triceratops, Iguanodon, and Megalosaurus: Hay, 520.

Turtles, from Harrison beds: Loomis, 779 .

of North America: Hay, 522.

Resin in Paleozoic coals: White, 1233.

Rhode Island.

Mineralogy.

Calcite crystals: Schaller, 1029

Rivers.

Illinois, Des Plaines Valley: Goldthwait, 461.

River waters, analyses of: Daly, 303.

Road materials.

New Jersey, Philadelphia district: Bascom et al., 74 .

Pennsylvania, Philadelphia district: Bascom et al., 74.

West Virginia, Marshall, Wetzel, and Tyler counties: Hennen, 537.

Rock glaciers: Capps, 197.

Rock slides. See Landslides.

Rock streams: Howe, 603.

Rocks described. See list, p. 160.

Rutile.

Virginia: 1305.

St. Vincent.

Soufrière: Anderson, 28; Hovey, 600.

Striations and U-shaped valleys: Hovey, 593.

Wallibu and Rabaka gorges: Hovey, 597.

Salt.

General.

Salt deposits, origin: Harris, 512

Louisiana: Harris, 512.

New York: Newland, 894.

Texas: Harris, 512.

United States (general): U. S. G. S., 1170.

West Virginia: Grimsley, 496.

Sand. See also Glass sand and Silica.

New York: Newland, 894.

Oregon, Portland: Darton, 308.

United States (general): U. S. G. S., 1170.

Sand-lime brick.

New York: Newland, 894

United States (general): U. S. G. S., 1170.

Sandstone. See also Building stone.

New York: Newland, 894.

United States (general): U. S. G. S., 1170.

West Virginia: Grimsley, 496.

Santa Cruz quadrangle: Branner et al., 138.

Santo Domingo.

Mineral resources: Kempton, 648.

\section{Sapphires.}

Montana: Rowe, 1017.

\section{Saskatchewan.}

General.

Churchill River and South Indian Lake: McInnes, 807 .

Economic.

Coal fields: Dowling, 350 .

Lignite areas: Dowling, 351 .

Scapolite rocks: Spurr, 1091
Sedimentation. See also Erosion.

Arizona, southern bolson region: Tolman, 1149 .

Carboniferous of Licking County, Ohio: Carney, 200.

Chemical composition for identifying metamorphosed sediments: Bastin, 82.

Coal, rate of deposition: Ashley, 37 .

Conglomerates, marine and terrestrial: Barrell, 68.

Continental formations of Tertiary: Matthew, 834.

Diatomaceous dust on Bering Sea ice floes: Kindle, 668.

Land deposits: Tolman, 1148.

Physiographic processes: Fenneman, 392.

St. Vincent Island: Hovey, 597.

Yakutat coastal plain of Alaska, formation of: Blackwelder, 118

Seismograms: Carter, 208

Selsmographs.

Kingston: Marvin, 823.

Seismological instruments: Reid, 993.

Seismology. See Earthquakes.

Selentum.

United States (general): U. S. G. S., 1170.

Shore lines. See also Beaches and Terraces.

Lakes Michigan and Huron: Goldthwait, 462. New York, Champlain coast lines: Hudson, 606. Ontario, Algonquin and Nipissing shore lines: Goldthwait and Jacobson, 46i3.

Sink holes.

Florida: Matson and Clapp, 829.

Silurian. For Lower Silurian see Ordovician.

General.

Classification of: Grabau, 471.

Evolution of North Amer:ca: Grabau, 472.

Nomenclature and subdivision of upper Siluric strata of Michigan, Ohio, and western New York: Lane et al., 733.

Paleogeographic map: Willis, 1256.

Stratigraphy:

Canada, maritime provinces: Matthew, 832 .

Georgia: Veatch, 1184

Illinois, Alexander County: Savage, 1027.

northwestern: Carman, 198.

Indiana, Waldron formation: Kindle and Barnett, 670 .

Iowa, eastern: Carman, 198.

Kentucky, Louisville region: Bassler, 80 .

Michigan, southern: Sherzer and Grabau, 1058. New Jersey: Kümmel, 682

Nova Scotia, Arisaig section: 'Twenhofel, 1158. Pennsylvania, Mercersburg-Chambersburg district: Stose, 1119.

Shawangunk: Grabau, 476.

Texas, El Paso quadrangle: Richardson, 998. Paleontology.

Graptolites from Niagaran dolomites of Hamilton, Ontario: Bassler, 80.

Indiana: Foerste, 409, 411.

Waldron fauna: Kindle and Barnett, 670 .

Kentucky: Foerste, 409, 411.

Nettleroth collection: Bassler, 80.

Nova Scotia, Arisaig section: Twenhofel, 1158. 
Silurian-Continued.

Paleontology-Continued.

Ohio: Foerste, 409.

Ontario, Albany River region: Whiteaves, 1240.

Tennessee: Foerste, 411.

Silver.

Arizona, Mohave County: Schrader, 1034.

Tombstone district: Shaw, 1055.

British Columbia, Bear River district: Rush, 1023.

Slocan district: LeRoy, 762 .

Canada: Young, 1297.

Colorado, A spen: Spurr, 1092.

Fall River district, Alice mine: Herrick, 542.

Gunnison County: Hill, 562 .

Montezuma district, Summit County: Patton, 943.

Idaho, Cœur d'Alene district: Rowe, 1016; Wiard, 1246 .

northern: MacDonald, 799 .

Massachusetts, Newburyport: Clapp and Ball, 229.

Mexico: Balarezo, 55: Bordeaux, 125.

Chihuahua, Rio Plata mine: Baron, 66.

Santa Eulalia mines: Merrill, 852.

San Ygnacio mine: Peragallo, 950.

El Chico district, Hidalgo: Thomas, 1145.

Guanajuato district: Botsford, 129.

Guerrero, Pregones district: Laguerenne, 691.

Montezuma district, EI Tigre mine: Herrick, 543.

Sinaloa, northern: Tays, 1142.

State of Mexico, Zacualpan district: Platt, 957.

Zacatecas, Concepcion del Oro district: Chase, 221.

Zacualpan district: Carpenter, 206

Montana, northwestern: MacDonald, 799.

Nevada, Hornsilver district: Ransome, 977.

Fumboldt County: Ransome, 980, 981.

Lida district: Root, 1015.

'Tonopah district: Jenney, 624; Johnson, 628 .

White Pine district: Larsh, 738.

Wonder district: Ritter, 1005.

New Mexico, Black Range mining district: Wright, 1294.

Lake Valley: MacDonald, 797.

Nicaragua, Matagalpa district: West, 1223.

North Carolina: Pratt, 964.

Ontario: Hore, 591.

Cobalt district: Higgins, 557; Ontario B. M., 909.

Gowganda and Miller lakes area: Burrows, 169.

Gowganda district: Collins, 276; West, 1222.

Maple Mountain district: Ramsay, 975 .

Montreal River district: Barlow, 64; Collins, 279.

Silver Islet vein, Lake Superior: McDermott, $795,796$.

South Lorraine area: Burrows, 170; Phillips, 953.

Texas, Presidio mines at Shafter: Kirk, 671.

United States (general): U. S. G. S., 1170: Lindgren, 772 .

Utah, Box Elder County: Higgins, 559.

Slate.

General.

Origin of: l'urdue, 972 .

Arkansas: Purdue, 972.

New York: Newland, 894.

United States (general): U. S. G. S.; 1170.

West Virginia: Grimsley, 496. .

Slickensides: Lawson, 739.

Soapstone.

North Carolina: Pratt, 964.

United States (general): U.S. G.S., 1170.

Solls.

General: Whitney ct al. 1244.

Soil surveys as related to geology: Kümmel, 687.

Soil wastage: Chamberlin, 215.

Indiana, Davièss County: Suider, 1087.

Dubois, Perry, and Crawford counties: Shannon, 1052 .

North Dakota, Jamestown-T'ower district: Willard, 1253.

South Dakota, Bellefourche quadrangle: Darton and $\mathrm{O}^{\prime} \mathrm{H}$ - 1 rra, 312 .

United States: Whitney, 1243.

West Virginia, Middlebourne area: Caine et al., 178.

Solidification of alloys and magmas: Aston, 39 .

South Carolina.

Economic.

Mineral resources: Sloane, 1068

Monazite: Pratt and Sterrett, 968.

Phosphate deposits: Matthew, 833; Van Horn, 1179.

Tin deposits: Ball, 59 .

Dynamic and structural.

Charleston earthquake: Hovey, 594.

Petrology.

Granites: Watson, 1211.

South Dakota.

General.

Aberdeen-Redfield district: Todd, 1146 .

Bad Lands: Fraas, 424.

Belle Fourche quadrangle: Darton and O'Harra, 31 .

Economic.

Belle Fourche quadrangle: Darton and O'Harra, 312.

Black Hills mother lode: Simmons, 1064.

Iron deposits of the Black Hills: Cooledge and Overspeck, 284.

Mica: Sterrett, 1103.

Tin in the Black Hills: Simmons, 10:3.

Tin, tungsten, and tantalum deposits: Hess, 549.

Physiographic.

Stream robbery in Belle Fourche district: Darton, 311.

Stratigraphic.

$A$ berdeen-Redfield district: Todd, 1146.

Belle Fourche quadrangle: Darton and O'Harra, 312.

Black Hills region: Darton, 306,310 .

Geology: Darton, 307

“.ell Creek and Cerators lieds: Knowlton, 678 .

Paleontology.

Ancodon: Matthew, 835 . 
South Dakota-Continued.

Underground watcr.

General: Darton, 307.

Aberdeen-Redfield district: Todd, 1146.

Artesian water, prediction of: Darton, 309.

Belle Fourche quadrangle: Darton and O'Har$\mathrm{ra}, 312$.

Black Fills region: Darton, 306.

Spheroidal weathering of dikes: Kemp, 645.,

Stalactites: Brigham, 141.

Stegocephala: Moodie, 876.

Stone. See Building stone.

Stratigraphic (general). For regional, see under the various States. See also the various systems.

General.

Early vertebrate faunas: Williston, 1259.

Mesozoic invertebrate faunas: Stanton, 1094.

Paleozoic floras: White, 1231.

Correlation.

Carboniferous, upper: Girty, 455 .

Ceratops beds: Stanton, 1095.

Devonian and Mississippian faunas: Weller, 1219.

Diastrophism as the ultimate basis of correlation: Chamberlin, 216.

Early vertebrate faunas: Williston, 1259 .

Glacial drift sheets: Alden, 12.

Laramie formation and Shoshone group: Cross, 294.

Mesozoic invertebrate faunas: Stanton, 1094.

Ontario, Simcoe sheet: Johnston, 633.

Ordovician, Silurian, and Devonian: Grabau, 472.

Orotaxial correlation: Keyes, 664.

Pacific Coast: Arnold, 32.

Paleozoic formations, upper: White, 1231 .

Paleozoic systems, revision of: Ulrich, 1166.

Pleistocene: Salisbury, 1024.

Pre-Cambrian: Adams, 3; Van Hise, 1177; Van Hise and Leith, 1178.

Symposium on correlation: Willis, 1257 .

Tertiary: Dall, 299

Tertiary formations: Oshorn, 913.

Nomenclature.

Laramie, application of term: Peale, 944.

Ontario drift deposits: Coleman, 269.

Silurian strata of Michigan, Ohio, and New York: Lane et al., 733 .

Tables of geologic formations.

Alaska, Fortymile quadrangle: Prindle, 969 .

Algonkian, Montana and Idaho: Calkins, 181.

Arkansas, Ouachita area: Purdue, 972.

California, Coalinga district: Arnold, 31 .

Furnace Canyon: Keyes, 656.

Santa Cruz quadrangle: Branner et al., 138.

Canada, middle: Dowling, 350.

Cincinnatian in Ohio: Foerste, 412.

Colorado, Grand Mesa coal field: Lee, 743 .

north central: Henderson, 536 .

Georgia: Veatch, 1184.

Florida: Matson, 828; Matson and Clapp, 829.

Illinois, Alexander County, Ordovician and Silurian formations: Savage, 1027.

northwestern: Carman, 198.

Iowa , eastern: Carman, 198.
Stratigraphic-Continued.

Tables of geologic formations-Continued.

Kansas, Carboniferous: Beede, 91; Haworth et al., 519.

Green County: Haworth and Bennett, 518.

Ozark region: Haworth and Bennett, 518 .

Kentucky, Blue Grass region: Matson, 827.

Louisiana, Austin quadrangle: Harris et al., 514 .

Caddo field: Harris et al., 514 .

salt region: Harris, 512 .

Mexico, Coahuila, coal-bearing strata: Aguilera, 10.

Missouri, southeastern: Buckley, 158.

Montana, Great Falls region: Fisher, 396, 397.

Nevada, Tonopah district: Burgess, 167.

New Jersey: Kümmel, 682 .

Philadelphia district: Bascom et al., 74.

Trenton quadrangle: Bascom et al., 75 .

New Mexico, Gallina-Raton Spring coal field: Gardner, 436.

Raton field: Lee, 744.

Rio Grande region: Lee, 745.

New York, Geneva-Ovid quadrangles: Luther, 786.

Watkins Glen-Catatonk district: Williams $e t$ al., 1255.

Oklahoma, Carboniferous: Beede, 91 .

Ohio, Devonian: Stauffer, 1096.

Ontario, Onaman iron range: Moore, 883.

Pleistocene: Coleman, 269.

Ordovician, Cincinnati area: Foerste, 413.

Ordovician, Silurian, and Devonian: Crabau, 472.

Paleozoic, lower: Grabau, 472.

Pennsylvania, Philadelphia district: Bascom et al., 74 .

Trenton quadrangle: Bascom et al., 75 .

Pre-Cambrian: Adams, 3; Van Hise and Leith, 1178.

South Dakota, Black Hills region: Darton, 306, 307.

Tertiary of California, Oregon, and Washington: Arnold, 32 .

Texas, Hemphill County: Eyerly, 383.

Utah, southern, coal region: Richardson, 999.

Virginia, western, Cambrian and Ordovician: Bassler, 78.

Wyoming, Bighorn Basin: Washburne, 1204.

Black Hills region: Darton, 306.

Great Divide Basin coal field: Smith, 1077.

Laramie Basin: Darton and Siebenthal, 313.

Little Snake River coal field: Ball, 57.

Sweetwater County: Schultz, 1039.

Stream work: Shattuck, 1053.

Strepsicerine antelopes: Merriam, 851 .

Striations and $U$-shaped valleys produced by other than glacial action: Hovey, 593.

\section{Strontium.}

United States (general): U. S. G. S., 1170.

Study and teaching. See Educational.

Subsidence. See Changes of level.

Subterranean water. See Underground water.

Sudbury: Ontario B. M., 909. 
Sulphate of soda.

California, San Luis Obispo County: Arnold and Johnson, 34 .

Wyoming, Laramie Basin: Darton and Siebenthal, 313.

Sulphur.

Alaska, Makushin deposits, Unalaska: Lawton, 741.

Canada: Young, 1297.

United States (general): U. S. G. S., 1170.

Wyoming, Thermopolis: Woodruff, 1285.

Surveys.

General.

State geological survey reports on limited areas: Carney, 199.

Alaska: Brooks, 147.

Colorado Geological Survey, report, 1908: George, 444.

Florida, state geologist's report: Sellards, 1048 Illinois, administrative report, 1908: Bain, 49. Illinois Geological Survey, work of: Bain, 47 .

Iowa, state geologist's seventeenth report: Calvin, 189.

Kansas survey, field work of: Haworth and Bennett, 517 .

Mexico, Chihuahua, northeastern: Rogers, 1012.

Instituto Geologico de Mexico: Aguilera, 11.

Maine, State Survey Commission; fifth biennial report: 811 .

Maryland Geological Survey reports: Clark, 234236 .

Michigan, state geologist's report, tenth: Lane, 727.

North Carolina, state geologist's biennial report: Pratt, 963, 965.

North Dakota Geological Survey, report for 1907 and 1908: Leonard, 757, 760.

United States Geological Survey, thirtieth annual report of the Director: Smith, 1082.

metalliferous ore investigations: Lindgren, 770.

nonmetallic mineral investigations: Hayes, 528.

Wisconsin, report of director, 1906-08: Birge,115. sixth biennial report: Wis. G. N. H. S., 1275 .

\section{Swamps.}

North Carolina: Davis, 314.

Tables of geologic formations. See Stratigraphic.

Talc.

New York: Newland, 894.

North Carolina: Pratt, 964.

Quebec: Dresser, 361 .

United States (general): U. S. G. S., 1170.

Tantalum.

South Dakota: Hess, 549.

Technique.

Apparatus for structural geology: Hobbs, 583.

Demonstrating ore formations, new method of: Nicholas, 895 .

Handbook for field geologists: Hayes, 525; (review) Lawson, 740 .

Instrumental surveying needed in practical geology: Lyman, 787.

Laboratory methods in vertebrate paleontology: Hermann, 541.

Preparation of geological papers: Wood, 1281.
Tellurium.

United States (general): U. S. G. S., 1170.

Tellurides: Lenher, 756 .

Tennessee.

Economic.

Chattanooga district, iron: Higgins, 556.

Clinton iron ore in Chattanooga region: Burchard, 164.

Phosphate deposits: Van Horn, 1179.

Zinc district, east Tennessee: Osgood, 919.

Paleontology.

Silurian fossils: Foerste, 411

Troost's crinoids of Tennessee: Wood, 1280.

- Teratornis: Miller, 864.

Terlingua, Texas, mercury minerals: Hillebrand and Schaller, 565 .

Terraces. See also Shore lines.

Illinois, Danville region: Wegemann, 1214.

northwestern: Carman, 198.

Iowa, eastern: Carman, 198.

West Virginia, Marshall, Wetzel, and Tyler counties: Hennen, 537.

Tertlary.

General: Dall, 299.

Erosion Intervals: Miller, 860 .

Land connection between North and South America: Scharff, 1030, 1031.

Paleogeographic map: Willis, 1256.

Correlation.

Fort Union formation, correlated beds: Knowlton, 678.

Hell Creek and Ceratops beds: Knowlton, 678 .

Tertiary correlation: Dall, 299.

Stratigraphy.

A laska, Fortymile quadrangle: Prindle, 969.

Kotsina-Chitina region: Moffit and Maddren, 875.

Yakutat Bay region: 'Tarr and Butler, 1138.

California: Arnold, 32

Coalinga district: Arnold, 31 .

McKittrick-Sunset district: Johnson, 631.

San Pablo formation: Weaver, 1212.

Santa Cruz quadrangle: Branner et al., 138. southern: Keyes, 660 .

Canada: Dowling, 350 .

Caribbean region: Guppy, 502 .

Colorado, Book Cliffs region: Richardson, 1000.

Grand Mesa coal field: Lee, 743.

Hahns Peak region, Routt County: George and Crawford, 446.

northwestern: Gale, 433 .

southern: Gardner, 437.

Florida: Matson, 828; Matson and Clapp, 829. southern: Sanford, 1025 .

Georgia: Veatch, 1184.

Greenland: Nordenskjöld, 900.

Kentucky, Blue Grass region: Matson, 827.

Louisiana: Harris, 512

northwestern: Harris et al., 514 .

Mexico, Baja California: Wittich, 1276

Coahuila: Agullera, 10.

Ixmiquilpan Valley, Hidalgo: Paredes, 940.

Miocene of Astoria and Coos Bay, Oregon: Dall, 300.

Montana, Bull Mountain coal field: Woolsey, 1288. 
Tertiary-Continued.

Stratigraphy-Continued.

Montana-Continued.

Crazy Mountains: Stone, 1115.

Custer National Forest: Wegemann, 1215.

Great Falls region: Fisher, 396 .

Miles City coal field: Collier and Smith, 274.

Milk River coal field: Pepperberg, 949 .

Red Lodge coal field: Woodruff, 1283.

Sentinel Butte lignite field: Leonard and Smith, 761.

Sweetgrass County: Douglass, 348 .

Nebraska, Pliocene: Matthew and Cook, 840. western: Peterson, 951.

Nevada, Goldfield district: Ransome, 976.

Reno region: Anderson, 25.

Silver Peak quadrangle: Turner, 1156.

Yerington district: Ransome, 979.

New Jersey: Kümmel, 682.

Philadelphia district: Bascom ct al., 74 .

Trenton quadrangle: Bascom ct al., $\mathbf{7 5}$.

New Mexico, Gallina-Raton Spring coal field:

Gardner, 436.

northern: Gardner, 437.

North Carolina: Miller, 860 .

North Dakota, Sentinel Butte lignite fleld: Leonard and Smith, 761.

Oregon: Arnold, 32.

Miocene of Astoria and Coos Bay: Dall, 300.

Pliocene of western Nebraska: Matthew and Cook, 840 .

South Dakota: Darton, 307.

Black Hills region: Darton, 306 .

Texas: Dumble, 363; Harris, 512.

Utah, Book Cliffs region: Richardson, 1000. northeastern: Gale, 433

Virginia: Miller, 860 .

Washington: Arnold, 32 .

Olympic Peninsula: Reagan, 989.

Western North America: Oshorn, 913.

Wyoming, Bighorn Basin: Washburne, 1204; Woodruffi, 1284.

Black Hills region: Darton, 306.

Bridger Basin: Matthew, 834.

Glenrock coal field: Shaw, 1054.

Great Divide Basin coal field: Smith, 1077.

Laramie Basin: Darton and Siebenthal, 313.

Little Snake River coal field: Ball, 57.

Sweetwater County: Schultz, 1039.

W ashakie faunal horizons: Granger, 482.

Washakie formation: Sinclair, 1065.

Paleontology.

Alabama, Claiborne shells: Wheeler, 1225.

Ancodon: Matthew, 835 .

California, Santa Clara lake beds, Carinifex: Hannibal, 507.

Coalinga district: Arnold, 31 .

Camel from lower Miocene of Nebraska: Cook, 281.

Caribbean region: Guppy, 502.

Carnivora and Insectivora of Bridger Basin Eocene: Matthew, 834 .

Coleoptera from Florissant: Wickham, 1247.

Colorado, Florissant plants: Cockerell, 264.

Miocene insects: Cockerell, 244, 245.

Fagopsis from Florissant: Hollick, 587.

Diptera from Florissant: Cockerell, 250.
Tertiary--Continued.

Paleontology-Continued.

Dromomeryx, new genus of American ruminants: Douglass, 349 .

Drumfish from Miocene: Smith, 1071.

Echinoids from Tertiary of California: Pack, 923.

Eocene fossils from Green River: Cockerell, 259.

Eocene insects from Colorado: Cockerell, 24i, 255.

Euphorbiaceæ: Cockerell, 262

Evolution and distribution of Tertiary faunas: Dall, 299.

Faunal lists of Tertiary Mammalia of the West: Matthew, 836.

Florissant fossils: Bather, 84; Cockerell; Rohwer, 1014

Fulgur: Maury, 841 .

Insecta: Cockerell.

Insecta from Florissant: Cockerell; Rohwer, 1013,1014

Hell Creek and Ceratops beds faunas: Knowlton, 678 .

Mammal horizons of western North America: Osborn, 913.

Mexico, Pliocene fauna from T'uxtepec: Böse 126.

Miocene insects from Florissant: Cockerell; Rohwer, 1013, 1014.

Miocene of Astoria and Coos Bay, Oregon: Dall, 300.

Nebraska, westerṇ: Peterson, 951.

Oligocene vertebrates from Wyoming: Matthew, 839 .

Pliocene fauna from western Nebraska: Matthew and Cook, 840 .

Proboscidean from Nebraska: Cook, 282.

Strepsicerine antelopes in Nevada: Merriam, 851.

Teleoceras from Nebraska Miocene: Olcott, 907.

'Tsetse fly from Florissant: Cockerell, 252.

Turtle from Miocene of Maryland: Palmer, 936.

Virginia, Miocene flora: Berry, 104.

Washington, Olympic Peninsula: Reagan, 989. Wyoming, Eocene fossils from Green River: Cockerell, 259.

Washakie faunal horizons: Granger, 482.

Texas.

General.

El Paso quadrangle: Richardson, 998.

Hemphill County: Eyerly, 383 .

Economic.

Celestite deposits: Hess, 551.

El Paso quadrangle: Richardson, 998.

Iron in east Texas: Linton, 775 .

Iron ores of Llano County: Phillips, 955.

Presidio silver mines, Shafter: Kirk, 671.

Quicksilver: Phillips, 954.

Quicksilver deposits of Brewster County: Dinsmore, 343 .

Rock salt: Harris, 512.

'Tin mine: Dinsmore, 344.

Dynamic and structural.

Clay dunes: Coffey, 265.

Rockwall: Paige, 928.

Physiographic.

Clay dunes: Coffey, 265. 
Texas-Continued.

Stratigraphic.

Chalk formations of northeast 'lexas: Gordon, 465; Hill, 563.

El Paso quadrangle: Richardson, 998.

Guadalupian stratigraphy: Girty, 456 .

Permian red beds: Case, 210.

Tertiary: Dumble, 363 .

Wichita-Brazos red beds: Gordon, 466.

Paleontology.

Permian crinoid fauna: Weller, 1220.

Permian reptiles: Matthew, 837 .

Trematops from the Permian: Williston, 1260.

Mineralogy.

Calcite crystals: Schaller, 1029.

Calomel: Goldschmidt and Mauritz, 459.

Mercury minerals from Terlingua: Hillebrand and Schaller, 565 .

Underground water.

El Paso quadrangle: Richardson, 998.

\section{Text-books.}

Crystallography: Wadsworth, 1195.

Igneous rocks: Iddings, 610 .

Laboratory manual in physical geography: Hopkins and Clark, 590.

Optical mineralogy, elements of: Winchell and Winchell, 1273.

\section{Thermal waters.}

Mexico, Queretaro, Montenegro: Villarello, 1185.

Yellowstone National Park, radioactivity of thermal waters of: Schlundt and Moore, 1033.

Tides: Chamberlin, 214.

Tin.

General: Lakes, 721.

Alaska, Seward Peninsula: Knopf, 676

North Carolina: Ball, 59.

South Carolina: Ball, 59; Hess, 549.

South Dakota, Black Hills: Simmons, 1063.

Texas: Dinsmore, 344.

El Paso quadrangle: Richardson, 998.

United States (general): U. S. G. S., 1170.

\section{Titanium.}

General: Baskerville, 76 .

United States (general): U. S. G. S., 1170.

Tourmalin.

Maine: Wade. 1194.

Trachodon: Osborn, 915, 917.

Trap.

New York: Newland, 894.

United States (general): U. S. G. S., 1170.

Trap sheets of the Lake Nipigon basin: Wilson, 1262 .

Trematops: Williston, 1260 .

Trenton quadrangle, New Jersey-Pennsylvania: Bascom et al., 75 .

Triassic.

General.

Paleogeographic map: Willis, 1256.

Stratigraphy.

Alaska, Cape Thompson: Kindle, 669 .

Kotsina-Chitina region: Moffit and Maddren, 875.
Triassic-Continued.

Stratigraphy-Continued.

Canada: Dowling, 350.

maritime provinces: Matthew, 832 .

Colorado, Hahns Peak region, Routt County: George and Crawford, 446.

north central: Henderson, 536 .

Connecticut: Gregory, 493.

Greenland: Nordenskjöld, 900.

New Jersey: Kümmel, 682.

Trenton quadrangle: Bascom et al., 75.

Pennsylvania, Philadelphia district: Bascom

- ct al., 74 .

T'renton quadrangle: Bascom et al., 75 .

South I)akota: Darton, 307.

Belle Fourche quadrangle: Darton and O'Harra, 312.

Black Hills region: Darton, 306 .

Wyoming, Black Hills region: Darton, 306.

Iaramie Basin: Darton and Siebenthal, 313.

Triceratops: Hay, 520.

Trilobites. Sce also Crustacea.

Auburn chert fauna, Missouri: Branson, 139.

Cincinnatian: Foerste, 412.

Silurian fossils from Indiana, Ohio, and Kentucky: Foerste, 409.

Tripoli.

Missouri, Seneca: Nelson, 891.

Tumanor Hills, Arizona: Tolman, 1148.

Tungsten.

General: Baskerville, 76; Dickinson, 338; Surr, 1122 .

A rizona, Dragoon: Richards, 996.

Whetstone Mountains: Hess, 550.

Canada: Walker, 1199, 1200; Young, 1297.

Colorado: Ekeley, 370; Hills, 568; Walker, 1199.

Boulder County: George, 443, 445.

Idabo, Coeur d'Alene district: Rowe, 1016.

Nova Scotia, Kings and Lunenburg counties: Faribanlt, 390.

South Dakota: Hess, 549.

United States (general): U. S. G. S., 1170; George, 445.

Turquoise.

Arizona: Platt, 956.

New Mexico: Jones, 637.

Turtles. See Reptilia.

Unalaska, Makushin sulphur deposits: Lawton, 741.

Unconformities.

Erosion intervals in Tertiary of North Carolina and Virginia: Miller, 860 .

Grenville-Hastings: Miller and Knight, 866 .

Missouri, southeastern: Buckley, 158.

New Mexico, Raton field: Lee, 744, 748 .

Valuation of: Blackwelder, 116.

Underground water (general). See also Geysers, Mineral waters, and Thermal waters. For regional see the various States.

General: Mendenhall, 844, 847.

Artesian waters of the Atlantic Coastal Plain: Fuller, 432

Classification of mineral waters: Bartow, 71 .

Crystalline rocks, water in: Clapp, 233. 
Onderground water-Continued.

Fffect of earthquakes on deep underground water circulation: Yeandle, 1296.

Geologic basis for artesian prediction: Darton, 309.

Ground water problems in the West: Mendenhall; 844 .

Mine waters, field assay: Lane, 728.

Ungulata. See Mammalia.

Upper Silurian. See Silurian.

\section{Uranium.}

General: Baskerville, 76; Dickinson, 338.

Colorado: Fleek, 399, 400.

United States (general): U. S. G. S., 1170.

\section{Utah.}

Economic.

Bingham Canyon: MacFarren, 805 .

Bingham copper district: MacFarlane, 804 .

Bingham district, Boston Consolidated: De Kalb, 335 .

Book Cliffs coal field: Richardson, 1000 .

Century and Susannah mines, Golden: Higgins, 560.

Green River oil fields in Wayne County: Peet, 945.

Harmony, Colob, and Kanab coal fields: Richardson, 999 .

Iron Springs district: Review: Kemp, 647.

Mineral deposits: Bradford, 134.

Napoleon-Maghera mines in Sierra Madre Mountains, Box Elder County: Higgins, 559.

Northeastern coal fields: Gale, 433 .

Oil field: Rogers, 1011.

Ozokerite: MacFarren, 806.

Phosphate deposits: Van Horn, 1179.

San Juan River gold:. Lakes, 693.

Sevier Consolidated mine of Gold MountainPiute County: Higgins, 558.

Utah copper mine: De Kalb, 334.

Physiographic.

Uinta and Wasatch Mountains: Atwood, 40.

Stratigraphic.

Book Cliffs coal field: Richardson, 1000.

Uinta and Wasatch Mountains: Atwood, 40.

Paleontology.

Ciar-pike: Cockerell, 260.

Mineralogy.

Amatrice: Zalinski, 1299.

Leadhillite: Palache and La Forge, 930.

Pyrite crystals from Bingham: Rogers, 1010.

Valleys.

General.

Formation of: Carney, 201; Fenneman, 392; Hovey, 593.

Hanging valleys: Johnson, 630 .

U-shaped valleys: Hovey, 593 .

Al laska, Yakutat Bay region: Tarr, 1136.

Illinois, Danville region: Wegemann, 1214.

northwestern: Carman, 198.

Iowa, eastern: Carman, 198.

Montana, Crazy Mountains: Mansfield, 813 .

New York, Moravia quadrangle: Carney, 203.

Watkins Glen-Catatonk district: Williams et al., 1255 .
Vanadium.

General: Baskerville, 76.

Colorado: Fleck, 399, 400 .

United States (general): U. S. G. S., 1170.

Vermont.

Economic.

Copper, Orange County: Fay, 391; Judson, 640. Granites: Dale, 297.

Vertebrata (general). See also Amphibia, Aves, Mammalia, Pisces, and Reptilia.

General: Moodie, S76; Woodward, 1286.

Aftonian mammalian fauna: Calvin, 188.

Correlation through vertebrate paleontology: Osborn and Matthew, $918^{\circ}$

Faunal relations of early vertebrates: Williston, 1259.

Laboratory methods in vertebrate paleontology: Hermann, 541.

Pliocene fauna from western Nebraska: Matthew and Cook, 840 .

Skeletons of fossil vertebrates, restoration of: Hay, 523.

Virginia.

Economic.

Cement resources: Massler, 78 .

Copper deposits of Greene County: Haney, 506.

Iron ores of Appalachian region: Irarder, 510 .

Lead and zinc ores: Caldwell, 180.

Manganese deposits: Ball, 58:

Mineral production in 1908: Watson, 1209.

Mineral resources: Schubert, 1035.

Pocket coal district in Little Black Mountain field: Fisher, 398

Rutile deposits: 1305 .

Stratigraphic.

Piedmont limestones: Mathews and Grasty, 825.

Tertiary erosion intervals: Miller, 860 .

Western Virginia: Bassler, 78.

Paleontology.

Cretaceous floras: Berry, 109.

Miocene flora: Berry, 104

Pleistocene swamp deposits: Berry, 108.

Mineralogy.

Calcite from Virgilina: Pogue, 958.

Volcanic rocks. See Igneous and volcanic rocks.

Volcanic topography: Smith, 1078.

Volcanoes.

General: Carter, 208; Hovey, 594.

Magmatic waters and volcanic action: Hixon, 574.

Seismic geology, evolution and outlook: Hobbs, 582.

Guatemala: Anderson, 27.

Hawaii: Hitchcock, 572 .

Kilauea: Hitchcock, 573.

Kilauea and Mauna Loa: Brigham, 141.

Mexico: Freudenberg, 430; Inkey, 615 .

Mont Pelé in 1908: Hovey, 601.

Volcanic bombs from Nova Scotia: Poole, 961 .

Washington.

General.

Geology and vein systems: Ingalls, 614. 
Washington-Continued.

\section{Economic.}

Coal resources: Tarr, 1134 :

Genlogy and vein systems: Ingalls, 614 .

Mineral resources: Northwest M. J., 901.

Selenium-bearing ores of Republic district: Lindgren, 774.

Structural materials: Darton, 308.

Physiographic.

Mount Rainier National Park: Roberts, 1006.

Stratigraphic.

Olympic Peninsula: Reagan, 989.

Sawtooth Range of Olympic Mountains: Arnold, 30 .

Tertiary: Arnold, 32.

Paleontology.

Olympic Peninsula: Reagan, 989.

Petrology.

Sawtooth Range of Olympic Mountains: Arnold, 30.

Water, underground. See Underground water.

Watkins Glen-Catatonk district: Williams et al., 1255.

Weathering.

Spheroidal weathering of dikes: Kemp, 645; Villars, 1193.

Soil wastage: Chamberlin, 215.

Weathering and erosion as time measures: Leverett, 763

Well records. See Borings.

Wells, deep, in southern Maine: Bayley, 87.

West Indies (general). See also the various islands. Caribbean region, geological connections: Guppy, 502.

\section{West Virginia.}

General.

Marshall, Wetzel, and Tyler counties: Hennen, 537.

Economic.

Coal: Stoek, 1110; White, 1231

central West Virginia: Stoek, 1113. upper Potomac fields: Stoek, 1112.

Iron ores, salt, and sandstones: Grimsley, 496.

Marshall, Wetzel, and Tyler counties: Hennen, 537.

Middlebourne area, soil survey: Caine ct al., 178 .

Physingraphic.

Marshall, Wetzel, and Tyler counties: Hennen, 537.

Strutigraphic.

Marshall, Wetzel, and Tyler counties: Hennen, 537.

\section{Wind work.}

General: Carman, 198.

Arizona, southern bolson region: Tolman, 1149. Base level of eolian erosion: Keyes, 655 .

Clay dunes: Coffey, 265.

Deflation in desert ranges: Keyes, 662

Denudation, error in estimating: Free, 427.

Eolian erosion upon varying rock-belts: Keyes, 654.

New Mexico: Keyes, 651.

Sand drift phenomena: Free, 428 .
Wisconsin.

General.

Geological survey, sixth biennial report: $W$ is

G. N. H. S., 1275.

Report of director of survey, 1906-08: Birge, 115.

Economic.

Copper, southwestern area: Cox, 289.

Iron fields of Lake Superior district: Brinsmade, 143 .

Lead and zinc fields: Brinsmade, 142.

Spring Valley brown iron ores: Allen, 16.

Stratigraphic.

Deposits on bluffs adjacent to the Mississippi: Squire, 1093.

Devonic, middle: Cleland, 242.

Discrimination of glacial drift sheets: Alden, 12.

Glacial phenomena of southeastern Wisconsin: Alden, 13, 14.

Wolframite. See also Tungsten.

A rizona, Whetstone Mountains: F ess, $\mathbf{5 5 0}$.

Wyoming.

Economic.

Asbestos deposits: Lakes, 710.

Bighorn Basin coal field: Washburne, 1204; Woodruff, 1284.

Glenrock coal field: Shaw, 1054.

Great Divide Basin coal field: Smith, 1077.

Laramie Basin: Darton and Siebenthal, 313.

Little Snake River coal field: Ball, 57.

Natural gas: Lakes, 706.

Phosphate deposits: Van Horn, 1179

Rock Springs coal field, Sweetwater County: Schultz, 1039:

Sheridan coal field: Taff, 1129.

Sulphur deposits, Thermopolis: Woodruff, 1285 .

Stratigraphic.

Black Hills region: Darton, 306.

Ceratops beds: Stanton, 1095 .

Hell Creek and Ceratops beds: Knowlton, 678 .

Laramie Basin: Darton and Siebenthal, 313.

Laramie beds of Converse County: Sternberg, 1100.

Laramie region: Blackwelder, 117.

Loup Fork beds: Riggs, 1004.

Washakie formation, faunal horizons: Granger, 482.

Washakie, volcanic ash formation: Sinclair, 1065.

Paleontology.

Carnivora and Insectivora of Bridger Basin Eocene: Matthew, 834 .

Eocene fossils from Green River: Cockerell, 259.

Iguanodont dinosaur, epidermis of: Osborn, 914.

Jurassic crinoid, new: Springer, 1090.

Loup Fork fauna: Riggs, 1004.

Oligocene vertebrates: Matthew, 839.

Rhynchocephalian reptile from Jurassic: Gilmore, 454.

Trachodon from Laramie beds of Converse County: Sternberg, 1099.

Underground water.

Black Hills region: Darton, 306.

Laramie Basin: Darton and Siebenthal, 313. 
Wyoming-Continued.

Underground water-Continued.

Yellowstone National Park, thermal waters, radioactivity of: Schlundt and Moore, 1033.

\section{Yukron.}

\section{General.}

Pelly River basin: Keele, 641 .

Whitehorse copper belt: McConnell, 791.

Whitehorse-Tantalus region: Cairnes, 179.

Econornic.

Whitehorse copper deposits: Stutzer, 1121.

Whitehorse-Tantalus region: Cairnes, 179.

Zinc.

Arizona, Mohave County: Schrader, 1034.

Canada: Young, 1297.

Colorado, Aspen: Spurr, 1092.

Montezuma district, Summit Counly: Patton, 943 .
Zinc-Continued.

Mexico, Chihuahua, Las Plomosas: Burrows, 171.

San YYgnacio mine: Peragallo, 950.

Missouri: Buckley, 160; Keyes, 658.

Joplin zinc belt, migrations of: Keyes, 659 .

Ozark region: Buckley, 159; Keyes, 653 .

Ozark deposits, genesis of: Keyes, 657.

Nevada, southern: White, 1235 .

New Jersey, Sussex County: Spencer, 1089.

New Mexico, Tres Hermanas district: Lindgren, 771.

Tennessee, east: Osgood, 919.

Virginia: Cald well, 180.

United Sttates (general): U.S. G. S., 1170; Lindgren, 772.

Wisconsin: Brinsmade, 142.

Zircon.

General: Baskerville, 76.

United States (general): U. S. G. S., 1170. 


\section{LISTS.}

\section{CHEMICAL ANALYSES.}

['T'he numbers refer to entries in the bibllography.]

Alamosite, 931.

Alaskite, 1156.

Amphibole, 781 .

Amphibolite, 2, 638 .

Andesite, 167, 960, 976 .

Antimony ore, 980 .

Argillite, 766.

Arizonite, 934

Augen-schist, 1156 .

Basalt, 75, 976.

Belcherose, 358 .

Benitoite, 781 .

Bentonite, 306,313 .

Bismite, 976 .

Bowlder, altered, 729 .

Caliche, 120.

Cancrinite, 4.

Cement materials, 948 .

Chalk, 465.

Chloropal, 1156.

Chromite, 1170.

Clay, $53,70,308,538,778,828,998,1119,1184$.

Clay ironstone, 1066.

Clinton ore, 1066.

Coal, 41, 57, 184, 185, 274, 313, 339, 350, 396, 398, 433, $437,538,540,758,761,784,949,997,1000,1039,1054$, $1077,1110,1129,1204,1230,1283,1284,1288$.

Cobalt, 980 .

Connellite, 932 .

Dacit $=, 290,976$.

Dawsonite, 468 .

Diabase, $74,75,82,638,764,960$.

Diabase porphyrite, 729 .

Diorite, 9 .

Dolomite, $78,158,115 \dot{6}$.

Dumortierite, 883 .

Eglestonite, 565 .

Epidote, 9, 175 .

Epsomite, 313.

Essexite, 2.

Feldspar, 4, 778 .

Ferberite, 443, 445, 470.

Fluorspar, 1170.

Fuller's earth, 1050.

Gabbro, 2, 74, 75 .

Ganister, 177 .

Gneiss, $74,75,82 ; 638,1211$.

Goldfieldite, 976 .

Granite, $9,74,638,766,1156,1201,1211$.

Granite augen schist, 1156 .

\author{
Granodiorite, 980 \\ Graphite, 1170. \\ Gypsum, 313, 467. \\ Hampdenite, 1009. \\ Hampshirite, 1009. \\ Hematite, 9, 1066 \\ Hornblende, 4.
}

Hornblende schist, $\mathrm{s} 2$.

Hornblende-biotite andesite, 976 .

Hornstone, 1158.

Hübnerite, 370 .

Igneous rocks, average, 856 .

Iodyrite, 681 .

Iron ore, $16,164,223,224,510,679,892,926,1217$, 1282.

Iron ore, Clinton, 892.

Kaolin, 212.

Kleinite, 565 .

Lava, 141.

Lignite, 701, 1074.

Limestone, $74,75,78,313,306,308,340,766,819,948$, $998,1119$.

Limonite, 1066.

Magnetite, 9, 86, 1066 .

Marble, 308.

Metagabbro, 74 .

Meteorites, 856 .

Mica schist, 638 .

Mine water, 729

Minette, 1034.

Montroydite, 565 .

Natural gas, 69, 1170.

Nepheline, 4.

Nepheline syenite, 75 .

Neptunite, 135.

Nickel ore, 980.

Paint ore, 1170.

Palisadose, 358 .

Peat, 112, 314.

Petroleum, 330, 1170.

Pitchblende, 399.

Portland cement, 308 .

Porphyrite, 729 .

Porphyry, 175, 638, 900.

Pyroxene, 1156.

Pyroxene-hornblende andesite, 976 .

Quartz schist, 638.

Quartzite, 74, 75 .

Retinite, 970 .

Rhyolite, 167, 960, 1034. 
Rhyolitic tuff, 1148.

River water, 303.

Scapolite, 9.

Schist, 74,638 .

Serpentine, 1009.

Shale, 70, 78, 306, 308, 538, 819, 998, 1184.

Slate, 1184 .

Sodalite, 4

Sodium sulphate, 34,313 .

Syenite, 5, 75 .

Syenite porphyry, 998 .

Terlinguaite, 565 .

Trachyte, 1034.

T'ungsten ore, 443, 1199.

Turquoise, 637.

Vesuvianite, 1156 .

Vogesite, 1034.

Volcanic ash, 313 .

Water, 72, 74, 303, 313, 346, 397, 532, 533, 728, 729, 732, $827,935$.

Wollramite, 370.

Yamaskose, 358.

Zinc blende, 1170 .

Zinc ore, 77 i.

MINERALS DESCRIBED.

Agyrine, 781.

Alamosite, 931.

Albite, 497, 781, 933.

Alunite, 976 .

Amatrice, 1299.

Amphibole, 781 .

Analcime, 124.

A pophyllite, 124.

Aragonite, 124.

Arizonite, 934 .

Autunite, 76, 1227.

Azurite, 875 .

Baddeleyite, 76 .

Barite, 565, 976.

Benitoite, 578-580, 781, 929.

Biotite, 5 .

Bismite, 976 .

Bismuthinite, 976 .

Boracite, 1196.

Bornite, 875 .

Brookite, 76 .

Calamine, 419.

Calaverite, 756 .

Calcite, 4, 124, 417, 565, 778, 958, 976, 1029.

Calomel, 459, 565 .

Cancrinite, 4 .

Carnotite, 76, 1227.

Cerargyrite, 976 .

Chabazite, 124.

Chalcanthite, 875 .

Chalcedony, 124 .

Chalcocite, 875.

Chalcopyrite, 875, 933.

Chlorite, 933.

Cleveite, 76.

Clinoenstatite, 1291, 1301.

Cobaltite, 933 .

Colemanite, 1196.

Connellite, 933.

Corundum, 4, 933.

Cuprite, 875.

Datolite, 418.

Dawsonite, 478.

Descloizite, 76.

Diaspore, 933, 976.

Diopside, 20, 325.

Dumortierite, 883.

Durdenite, 976 .

Eglestonite, 565.

Emmonsite, 976 .

Enargite, 976.

Enstatite, 1291, 1301.
Epidote, 933, 976.

Eucolite, 4.

Eudialyte, 76.

Famatinite, 976 .

Feldspar, 4, 778, 976.

Ferberite, 370, 443, 445.

Garnet, 4.

Glauconite, 778.

Goldfieldite, 976 .

Graphite, 4.

Gummite, 76.

Gypsum, 565, 778, 976 .

Halotrichite, 976.

Hampdenite 1009.

Hampshirite, 1009.

Hematite, 778, 976.

Heulandite, 124.

Hornblende, 4, 778.

Hübnerite, 76, 443, 445, 1199.

Ilmenite, 76, 778, 933.

Iodyrite, 681 .

Jarosite, 565, 976.

Kaolinite, 778, 976.

Kleinite. 565 .

Krennerite, 756.

Laumontite, 124.

Leadhillite, 930.

Levynite, 124.

Limonite, 976.

Magnetite, 4, 933, 1009.

Malachite, 875 .

Marcasite, 778, 976.

Melanterite, 976 .

Mercury, 565.

Mesolite, 124.

Mica, 778.

Monazite, 966 .

Montroydite, 565 .

Muscovite, 4, 976.

Natrolite, 124, 581, 781.

Nepheline, 4.

Neptunite, 135, 410̉, 581, 781 .

Nesquehonite, 478.

Nivenite, 76.

Nontronite, 98.

Pandermite, 1196.

Perofskite, 76.

Pyrite, 778, 933, 976, 1010.

Pyromorphite, 131 .

Quartz, 124, 778, 976.

Roscoelite, 76 .

Rutile, 76, 778, 933. 
Scapolite, 4.

Scheelite, 76, 443, 445, 1199.

Scolecite, 124.

Siderite, 778.

Sodalite, 4.

Stilbite, 124.

Sulphur, 976.

Sylvanite, 756 .

Tellurium, 756.

Tenorite, 875 .

Terlinguaite, 565 .

Thomsonite, 124.

Thorogummite, 76 .

Tincal, 1196.
Titanite, 76.

Torbercite, 76

Tourmaline, 883, 933.

Tungstite, 1199.

Turquoise, 637.

Ulexite, 1196.

Uraninite, 76.

Uranophane, 76 .

Uranosphærite, 76 . .

Utahlite, 1299.

Vanadinite, 76.

Wolframite, 76, 443, 445, 1199.

Zircon, 4, 76 .

\section{ROCKS DESCRIBED.}

Alaskite, 976, 1156.

Alunite, 767 .

Amphibolite; 2, 638, 1164

Andesite, 167, 290, 291, 446, 960, 976, 1034, 1156.

Andesite porphyry, 999 .

Andose, 2.

A plite, 290, 1201.

Aporhyolite, 1119.

Augite camptonite, 174.

Basalt, 74, 138, 181, 291, 900, 976, 1148, 1156.

Basalt porphyry, 291.

Biotite andesite, 1148.

Biotite gneiss, 1164

Biotite granite, 174.

Breccia, 960 .

Bruniase, 358.

Camptonose, 82 .

Chert, 30. .

Conglomerate, 174 .

Dacite, 290, 291. 960, 1156.

Dacite porphyry, 446.

Diabase, $30,74,75,138,174,290 ; 291,638,883,960$, 999, 1034

Diorite, 2, 181, 368, 446, 735 .

Dolomite, 1164.

Epidote, pyrogenetic, 175.

Felsite, 291.

Foliates, 82.

Gabbro, 74, 75, 446, 960.

Gneiss, 74, 75, 82, 86, 290, 445, 638, 679, 867, 1156, 1164 .

Granite, 74, 82, 290, 368, 445, 638, 679, 735, 976, 99?

$1125,1156,1201$.

Granite gneiss, 74 .

Granite porphyry, 1034.

Granodiorite, 97, 181.

Graywacke, 174, 1164

Greenstone, 735, 883.

Hornblende gneiss, 75, 1164.

Kedabekase, 960 .

Kersantite, 1034

Lamprophyre,181, 291.
Lassenose, 960 .

Latite, 290, 291, 446.

Latite porphyry, 291, 446.

Limburgite, 291.

Limestone, 74.

Metabasalt, 1119.

Metagabbro, 74 .

Metaperidotite, 75 .

Metapyroxenite, 75 .

Metarhyolite, 1156 .

Mica schist, 638 .

Minette, 1034.

Monzonite, 290.

Muscovite granite, 174 .

Nepheline syenite, 4,74 .

Olivine basalt, 446, 1148.

Palisadose, 358.

Pantellerose, 960.

Pegmatite, 86, 138, 290, 445, 1164, 1201, 1203.

Phyllite, 82.

Porphyry, 290, 446, 638, 900.

Pyroxenite, 291.

Quartz basalt, 446 .

Quartz diorite, 138, 174, 1156 .

Quartz monzonite, 181, 1156.

Quartz schist, 638.

Quartzite, 74, 75.

Quebecase, 358 .

Rhyolite, 167, 290, 446, 883, 960, 976, 1034, 1156.

Rhyolite porphyry, 446,883 .

Rhyolitic tuff, 1148.

Sandstone, 30

Schist, 30, 74, 290, 638, 679, 883, 1156.

Serpentine, $30,138$.

Slate, $82,174,960$.

Syenite, 4, 75, 181 .

Syenite gneiss, 867 :

Syenite porphyry, 999 .

Trachyte, 290.

Tuff, 138, 960, 976.

Vogesite, 1034.

\section{GEOLOGIC FORMATIONS DESCRIBED.}

Abilene conglomerate, Carboniferous, Kansas: Beede, 90.

Abo sandstone, Pennsylvanian, New Mexico: Lee, 745.

Acadian, Cambrian, North America: Grạbau, 472. Admire formation, Carboniferous, Kansas:

Haworth and Bennett, 518 .

Aftonian beds, Pleistocene, Iowa: Shimek, 1060.
Aftonian interglacial epoch, Quaternary, Illịnois and Iowa: Carman, 198.

Aftonian interglacial interval, Pleistocene, Iowa: Calvin, 187.

Akron dolomite (Bullhead), Silurian, New York: Sherzer and Grabau, 1058.

Alachua clays, Pliocene, Florida: Matson and Clapp, 829. 
Alexandrian series, Silurian, Illinois and Missouri: Savage, 1027.

Alger member, Silurian, Kentucky: Foerste, 409.

Algonquin clay, Pleistocene, Ontario: Coleman, 269.

Allegheny series, Carboniferous, West Virginia: Hennen, 537.

Allen limestone, Carboniferous, Kansas: Haworth and Bennett, 518 .

Allentown limestone, Cambrian, Pennsylvania: Wherry, 1229.

Altamaha formation, Tertiary, Georgia: Veatch, 1184.

Altamont limestone, Carboniferous, Kansas: Haworth and Bennett, 518 .

Alum Bluff formation, Oligocene, Florida: Matson and Clapp, 829.

American Fork formation, Cretaceous, Montana: Douglass, 348 .

Americus limestone, Carboniferous, Kansas: Haworth and Bennett, 518 .

Ames limestone, Carboniferous, Ohio: Condit, 280.

Ames limestone, Carboniferous, Pennsylvania: Raymond, 983.

Amherstburg bed, Silurian, Michigan: Lane et al., 733.

Amherstburg dolomite, Silurian, Michigan and adjacent: Sherzer and Grabau, 1058.

Anamosa limestone, Silurian, Illinois and Iowa: Carman, 198.

Anderdon coral limestone, Silurian, Michigan and adjacent: Sherzer and Grabau, 1058.

Anderdon limestone, Śilurian, Michigan: Lane et al., 733.

Annona chalk, Cretaceous, Texas: Gordon, 465.

Antietam sandstone, Cambrian, Pennsylvania: Stose, 1119.

Antietam sandstone, Cambrian, Virginia: Bassler, 78.

Apalachiola group, Oligocene, Florida: Matson and Clapp, 829.

Appanoose formation, Carboniferous, Iowa: Lees, 751 .

Arcadia marl, Pliocene, Florida: Matson and Clapp, 829

Archer beds, Pliocene, Florida: Matson and Clapp, 829

Arisaig formation, Silurian, Nova Scotia: Twenhofel, 1158

Arkansas novaculite, Arkansas: Purdue, 972.

Aspalaga marl, Oligocene, Florida: Matson and Clapp, 829 .

Astoria shales, Tertiary, Oregon: Dall, 300.

Athens shale, Ordovician, Virginia: Bassler, 78.

Atoka formation, Carboniferous, Oklahoma: Taff, 1130.

Aurora formation, Mexico: Burrows, 171.

Austin formation, Cretaceous, Texas: Gordon, 465 .

Bailey (Lower Helderberg), Silurian, Missouri: Buckley, 158.

Bainbridge (Niagara), Silurian, Missouri: Buckley, 158.

Bald Eagle conglomerate, Ordovician, Pennsylvania: Grabau, 472, 476.

Baltimore gneiss, pre-Cambrian, Pennsylvania: Bascom, 73; Bascom et al., 74, 75.
Bandera shales, Carboniferous, Kansas: Haworth and Bennett, 518.

Bangor limestone, Carboniferous, Georgia: Veatch, 1184.

Bass Island series (lower Monroe), Silurian: Lane et al., 733 .

Bays sandstone, Ordovician, Virginia: Bassler, 78. Beacon Hill formation, Pliocene, New Jersey: Kü̈mmel, 682.

Bear Mountain granite, Colorado: Patton, 943.

Bearpaw, Cretaceous, Canada: Dowling, 350.

Rearpaw shale, Cretaceous, Montana: Pepperberg, 948, 949; Stone, 1114.

Bearpaw shale, Cretaceous, 'Wyoming: Washburne, 1204.

Bearpaw shales, Cretaceous, Montana: Douglass, 348.

Beaver limestone, Cambrian, Georgia: Veatch, 1184.

Beavertown marl, Silurian, Ohio: Foerste, 409.

Becraft limestone, Devonian, New Jersey: Kümmel, 682 .

Bedford formation, Mississippian, Ohio and Kentucky: Morse and Foerste, 887.

Bedford shale, Carboniferous, Ohio: Carney, 200.

Beekmantown limestone, Ordovician, Pennsylvania: Stose, 1119.

Beekmantown limestone, Ordovician, Virginia: Bassler, 78 .

Beekmantownian, Ordovician: Grabau, 472.

Bellvale sandstone, Devonian, New Jersey: Kümmel, 682 .

Belly River, Cretaceous, Canada: Dowling, 350 .

Belly River formation, Cretaceous, Alberta: Dowling, 352.

Benton, Cretaceous, Canada: Dowling, 350.

Benton formation, Cretaceous, Colorado: Henderson, 536 .

Benton formation, Cretaceous, Wyoming: Darton and Siebenthal, 313

Benton group, Cretaceous, South Dakota: Darton, 307.

Benton shale, Cretaceous, North Dakota: Barry and Melsted, 70

Benton shale, Cretaceous, South Dakota: Todd, 1146.

Benwood limestone, Carboniferous, West Virginia: Hennen, 537.

Berea formation, Carboniferous, Ohio: Carney, 200. Berea grit, Mississippian, Ohio and Kentucky: Morse and Foerste, 887.

Bertie waterlime, Silurian, New York: Luther, 786. Bethany Falls limestone, Carboniferous, Kansas: Haworth and Bennett, 518 .

Big Blue series, Carboniferous, Kansas: Haworth and Bennett, 518 .

Bigfork chert, Ordovician, Arkansas: Purdue, 972, 973.

Birdsville formation, Mississippian, Missouri: Buck * ley, 158.

Birmingham shale, Carboniferous, Pennsylvania: Raymond, 983, 984.

Black Hand formation, Carboniferous, Ohio: Carney; 200.

Black Hand formation, Mississippian, Ohio and Kentucky: Morse and Foerste, 887.

$$
56693^{\circ}-\text { Bull. } 444-10-11
$$


Black River formation, Ordovician, New York: Miller, 867.

Bladen formation, Cretaceous, North Carolina: Stephenson, 1098.

Blanchester division, Ordovician, Ohio: Foerste, 413.

Blanchester division, Ordovician, Ohio and Indiana: Foerste, 411.

Blaylock sandstone, Ordovician, Arkansas: Purdue, $972,973$.

Bliss sandstone, Cambrian, Texas: Richardson, 998. Blossom sands, Cretaceous, Texas: Gordon, 465.

Blufftown marl, Cretaceous, Georgia: Veatch, 1184.

Bone Valley gravel, Pliocene, Florida: Matson and Clapp, 829.

Bonterre formation, Cambrian, Missouri: Buckley, 158.

Boquilla slates, Mexico: Burrows, 171.

Bossardville limestone, Silurian, New Jersey: Kümmel, 682.

Bowie shale, Cretaceous, Colorado: Lee, 743.

Brassfield limestone, Silurian, Kentucky and Ohio: Foerste, 409.

Bretonian, Cambrian, North America: Grabau, 472.

Bridger formation, Eocene, Wyoming: Matthew, 834.

Bridger formation, Tertiary, Wyoming: Sinclair, 1065.

Bridgeton formation, Pleistocene, New Jersey: Kümmel, 682 .

Bridgeton formation, Quaternary, New Jersey: Bascom et al., 74, 75.

Brown Park formation, Tertiary, Colorado: Gale, 433.

Brownstown marls, Cretaceous, Texas: Gordon, 465.

Brunswick beds, Triassic, New Jersey: Kümmel, 682.

Brunswick shale, Triassic, Pennsylvania: Bascom, et al., 74, 75.

Brush Creek formation, Carboniferous, Pennsylvania: Raymond, 983.

Buena Vista member, Mississippian, Kentucky: Morse and Foerste, 887

Bufa sandstone, Mexico: Botsford, 129.

Buffalo sandstone, Carboniferous, Pennsylvania: Raymond, 983.

Bullhead dolomite (Akron), Silurian, New York: Sherzer and Grabau, 1058.

Burches Ferry formation, Cretaceous, North Carolina: Stephenson, 1098.

Burke formation, Algonkian, Idaho and Montana: Calkins, 181.

Burlingame limestone, Carboniferous, Kansas: Haworth and Bennett, 518.

Burlington formation, Mississippian, Missouri: Buckley, 158.

Burton sandstone, Carboniferous, West Virginia: Hennen, 537.

Bushberg sandstone, Devonian, Missouri: Buckley, 158.

Butano sandstone, Oligocene, California: Branner et al., 138.

Byram gneiss, New Jersey: Bayley, 86.

Byram gneiss, pre-Cambrian, New Jersey: Kümmel, 682. '

Caddo shale, Ordovician, Arkansas: Purdue, 973.

Calhoun shales, Carboniferous, Kansas: Haworth and Bennett, 518 .
Calico Bluff formation, Carboniferous, Alaska: Prindle, 969.

Callaway limestone, Devonian, Missouri: Greger, 491.

Caloosahatchee marl, Pliocene, Florida: Matson and Clapp, 829.

Cambridge limestone, Carboniferous, Ohio: Condit, 280.

Camillus shale, Silurian, New York: Luther, 786.

Caney shale, Carboniferous, Oklahoma: Girty, 455, 457; Taff, 1130, 1131.

Cape Brown series, Triassic, Greenland: Nordenskjöld, 900.

Cape Fear formation, Cretaceous, North Carolina: Stephenson, 1098.

Cape Fletcher formation, Greenland: Nordenskjöld, 900.

Cape Girardeau, Silurian, Missouri: Buckley, 158.

Cape Leslie sandstone, Jurassic, Greenland: Nordenskjöld, 900 .

Cape May formation, Pleistocene, New Jersey: Kümmel, 682.

Cape May formation, Quaternary, Delaware, Pennsylvania, and New Jersey: Bascom et al., 74, 75.

Cape Stewart beds, Jurassic, Greenland: Nordenskjöld, 900 .

Cardiff shale, Devonian, New York: Luther, 786.

Carlile shale, Cretaceous, South Dakota: Darton, 307; Darton and O'Harra, 312.

Carlile shale, Cretaceous, Wyoming and South Dakota: Darton, 306.

Carolina gneiss, Archean, North and South Carolina: Pratt and Sterrett, 968.

Cascade formation, Cretaceous, Montana: Fisher, 397.

Cashaqua River shale, Devonian, New York: Luther, 786.

Casper formation, Carboniferous, Wyoming: Darton and Siebenthal, 313.

Cassville plant shale, Carboniferous, West Virginia: Hennen, 537.

Castle limestone member, Carboniferous, Montana: Fisher, 396.

Catskill formation, Devonian, New York: Williams, 1254.

Catskill formation, Devonian, Pennsylvania: Stose, 1119.

Cayuga formation, Silurian, Pennsylvania: Stose, 1119.

Cayugan, Silurian, New York: Luther, 786

Cayuta shale member, Devonian, New York: Williams, 1254.

Ceratops beds, Cretaceous, Wyoming and Montana: Stanton, 1094

Ceratops beds, Eocene, Wyoming: Knowlton, 678 . Chadron formation, Tertiary, wyoming and South Dakota: Darton, 306.

Chambersburg formation, Ordovician, Virginia: Bassler, 78.

Chambersburg limestone, Ordovician, Pennsylvania: Stose, 1119.

Chanute shales, Carboniferous, Kansas: Haworth and Bennett, 518 .

Chase stage, Carboniferous, Kansas: Haworth and Bennett, 518.

Chattahoochee formation, Oligocene, Florida: Mat. son and Clapp, 829. 
Chemung formation, Devonian, New York: Williams, 1254

Chattahoochee group, Tertiary, Georgin: Veatch, 1184.

Chattanooga shale, Devonian, Georgia: Veatch, 1184.

Chazy, Ordovician, North America: Grabau, 472.

Chazyan, Ordovician: Grabau, 472.

Chemung formation, Devonian, Pennsylvania: Stose, 1119.

Chemung or Kinderhook, Mississippian, Missouri: Buckley, 158.

Cherokee beds, Carboniferous, Iowa: Lees, 751.

Cherokee shales, Carboniferous; Kansas: Haworth and Bennett, 518.

Cherokee.stage, Carboniferous, Kansas: Haworth and Bennett, 518 .

Cherryvale shales, Carboniferous, Kansas: Haworth and Bennett, 518 .

Chester formation, Mississippian, Illinois and Missouri: Fenneman, 392 .

Chicamauga limestone, Ordovician, Georgia: Veatch, 1184.

Chickamauga limestone, Ordovician, Virginia: Bassler, 78 .

Chickies quartzite, Cambrian, Pennsylvania: Bascom et al., 74, 75 .

Chico formation, Cretaceous, California: Arnold, 31; Branner, et al., 138.

Chipola marl member, Oligocene, Florida: Matson and Clapp, 829

Chispa andesite, Tertiary, Nevada: Ransome, 976. Chitistone limestone, Triassie, Alaska: Moffit and Maddren, 875.

Choctawhatchee marl, Pliocene, Florida: Matson and Clapp, 829 .

Chouteau formation, Mississippian, Missouri: Buckley, 158.

Chouteau limestone, Mississippian, Missouri and Illinois: Weller, 1218.

Chugwater formation, Triassic?, Wyoming: Darton and Siebenthal, 313 .

Cimarron series, Carboniferous, Kansas: Haworth and Bennett, 518 .

Claggett, 'Cretaceous, Canada: Dowling, 350.

Claggett beds, Cretaceous, Montana: Douglass, 348.

Claggett formation, Cretaceous, Montana: Fisher, 397; Pepperberg, 949; Stone, 1114.

Claggett formation, Cretaceous, Wyoming: Washburne, 1204

Claiborne group, Tertiary, Georgia: Veatch, 1184.

Claiborne stage, Eocene, Louisiana and Texas: Harris, 512.

Clallam formation, Oligocene-Miocene, Washington: Reagan, 989.

Clarke interglacial, Pleistocene, Ontario: Coleman, 269.

Clarksville division, Ohio: Foerste, 413

Clear Creek (Oriskany), Devonian, Missouri: Buckley, 158.

Clinch sandstone, Ordovician, Virginia: Bassler, 78.

Clinton limestone, Silurian, Indiana: Kindle and Barnett, 670 .

Clinton shale, Silurian, Pennsylvania: Stose, 1119.

Cloverly formation, Cretaceous, Wyoming: Darton

and Siebenthal, 313; Washburne, 1204.

Coaledo formation, Tertiary, Oregon: Dall, 300.
Cobleskill waterlime, Silurian, New York: Luther, 786.

Coeymans limestone, Devonian, New Jersey: Kümmel, 682 .

Coffeyville limestone, Carboniferous, Kansas: Haworth and Bennett, 518 .

Cohansey sand, Miocene, New Jersey: Kümmel, 682.

Cohansey sand, Tertiary, New Jersey: Bascom et $a l ., 74,75$.

Collier shale, Arkansas: Purdue, 972, 973.

Colorado formation, Cretaceous, Montana: Fisher, 397.

Colorado formation, Cretaceous, North Dakota: Barry and Melsted, 70.

Colorado formation, Cretaceous, Texas: Richardson, 998.

Colorado group, Cretaceous, Colorado: Henderson, 536.

Colorado group, Cretaceous, South Dakota: Todd, 1146.

Colorado group, Cretaceous, Wyoming: Smith, 1077.

Colorado shale, Cretaceous, Montana: Calvert, 185; Fisher, 396; Stone, 1114.

Colorado shale, Cretaceous, Wyoming: Washburne, 1204; Woodruff, 1284.

Columbia formation, Pleistocene, Georgia: Veatch, 1184.

Columbus limestone, Devonian, Ohio: Stauffer, 1096.

Comanche formation, Cretaceous, Colorado: Henderson, 536

Comanche series, Cretaceous, Texas: Richardson, 998.

Conasauga shale, Cambrian, Georgia: Veatch, 1184.

Conchos gravels, Mexico: Burrows, 171.

Conemaugh formation, Carboniferous, Ohio: Condit, 280.

Conemaugh series, Carboniferous, West Virginia: Hennen, 537.

Conococheague limestone, Cambrian, Pennsylvania: Stose, 1119.

Conococheague limestone, Cambro-Ordovician, Virginia: Bassler, 78.

Coos conglomerate, Tertiary: Dall, 300 .

Coplay limestone, Ordovician, Pennsylvania: Wherry, 1229.

Cottonwood limestone, Carboniferous, Kansas: Haworth and Bennett, 518.

Cottonwood white layer, Eocene, Wyoming: Matthew, 834.

Council Grove stage, Carboniferous, Kansas: Haworth and Bennett, 518 .

Crab Orchard formation, Silurian, Kentucky: Foerste, 409.

Craghead Creek shale, Devonian, Missouri; Greger, 491.

Crescent formation, Eocene, Washington: Reagan, 989.

Crystal Mountain sandstone, Ordovician, Arkansas: Purdue, 972, 973.

Cuchillo formation, Mexico: Burrows, 171.

Cusseta sand, Cretaceous, Georgia: Veatch, 1184.

Cuyahoga formation, Carboniferous, Ohio: Carney, 200. 
Cuyahoga formation, Mississippian, Ohio and Kentucky: Morse and Foerste, 887.

Cynthiana formation, Ordovician, Kentucky: Foerste, 413.

Cynthiana formation, Ordovician, Ohio and Kentucky: Foerste, 412 .

Cypress formation, Mississippian, Missouri: Buckley, 158.

Dakota, Cretaceous, Canada: Dowling, 350 .

Dakota formation, Cretaceous, Colorado: George and Crawford, 446; Henderson, 536.

Dakota sandstone, Cretaceous, Colorado: Gale, 433; Martin, 819.

Dakota sandstone, Cretaceous, Colorado and Utah: Richardson, 1000.

Dakota sandstone, Cretaceous, New Mexico: Gardner, 436.

Dakota sandstone, Cretaceous, North Dakota: Barry and Melsted, 70; Willard, 1253.

Dakota sandstone, Cretaceous, South Dakota: Darton, 307; Darton and O'Harra, 312; Todd, 1146.

Dakota sandstone, Cretaceous, Wyoming and South Dakota: Darton, 306.

Davis formation, Cambrian, Missouri: Buckley, 158.

Deadwood sandstone, Cambrian, South Dakota: Darton, 307.

Deadwood formation, Cambrian, Wyoming and South Dakota: Darton, 306.

Decker Ferry formation, Silurian, New Jersey: Kümmel, 682.

Deer Creek limestone, Carboniferous, Kansas: Haworth and Bennett, 518.

Delaware limestone, Devonian, Ohio: Stauffer, 1096.

Dennis limestone, Carboniferous, Kansas: Haworth

and Bennett, 518 .

Derby formation, Cambrian, Missouri: Buckley, 158 .

Des Moines stage, Carboniferous, Iowa: Lees, 751 .

De Soto beds, Pliocene, Florida: Matson and Clapp, 829.

Detroit River series (upper Monroe), Silurian: Lane et al., 733.

Doerun formation, Cambrian, Missouri: Buckley, 158.

Dolgeville shales, Ordovician, New York: Miller, 867.

Don beds, Pleistocene, Ontario: Coleman, 269.

Douglas stage, Carboniferous, Kansas: Haworth and Bennett, 518 .

Doyle shales, Carboniferous, Kansas: Haworth and Bennett, 518.

Dripping Spring quartzite, Cambrian, Arizona: Truesdell, 1155

Drum limestone, Carboniferous, Kansas: Haworth and Bennett, 518

Dundee limestone, Devonian, Michigan and adjacent: Sherzer and Grabau, 1058.

Dunkard series, Carboniferous, West Virginia: Hennen, 537.

Eagle, Cretaceous, Canada: Dowling, 350 .

Eagle beds, Cretaceous, Montana: Douglass, 348.

Eagle sandstone, Cretaceous, Montana: Calvert, 185; Fisher, 397; Pepperberg, 949; Stone, 1114.

Eagle sandstone, Cretaceous, Wyoming: Washburne, 1204; Woodruff, 1284.
Eagle Ford formation, Cretaceous, Texas: Gordon, 465.

Eden formation, Ordovician, Cincinnati region: Grabau, 472.

Eden shale, Ordovician, Kentucky: Matson, 827.

Edgewood limestone, Silurian, Illinois and Missouri: Savage, 1027.

Edmonton, Cretaceous, Alberta: Dowling, 350.

Edmonton formation, Cretaceous, Alberta: Dowling, 352.

Elbert formation, Devonian, Colorado: Kindle, 666 . Elbrook formation, Cambrian, Pennsylvania: Stose, 1119.

Elbrook limestone, Cambro-Ordovician, Virginia: Bassler, 78.

Ellis formation, Jurassic, Montana: Calvert, 185, Fisher, 396, 397.

Elmdale formation, Carboniferous, Kansas: Haworth and Bennett, 518 .

Elm Grove limestone, Carboniferous, West Virginia: Hennen, 537.

El Paso limestone, Ordovician, Texas: Richardson, 998.

Eminence formation, Cambrian, Missouri: Buckley, 158.

Empire formation, Tertiary,. Oregon: Dall, 300.

Emporia limestone, Carboniferous, Kansas: Haworth and Bennett, 518 .

Enfield shale member, Devonian, New York: Williams, 1254.

Englewood limestone, Carboniferous, South Dakota: Darton, 307.

Englewood limestone, Carboniferous, Wyoming and South Dakota: Darton, 306.

Englishtown sand, Cretaceous, New Jersey: Bascom et. al., 74, 75; Kümmel, 682 .

Enterprise shales, Carboniferous, Kansas: Beede, 90

Erian, Devorian, New York: Luther, 786.

Eskridge shales, Carboniferous, Kansas: Haworth and Bennett, 518 .

Esmeralda formation, Tertiary, Nevada: Turner, 1156.

Esopus grit, Devonian, New Jersey: Kümmel, 682. Espina breccia, Tertiary, Nevada: Ransome, 976. Estill clay, Silurian, Kentucky: Foerste, 409.

Etchegoin formation, Miocene, California: Arnold, 30 .

Etchegoin-Jacalitos formation, California: Johnson, 631.

Etcheminian, Cambrian, North America: Grabau, 472.

Eutaw formation, Cretaceous, Georgia: Veatch, 1184.

Everglades limestone, Pleistocene, Florida: Matson and Clapp, 829.

Fern Glen formation, Devonian, Missouri: Buckley, 158.

Fern Glen formation, Mississippian, Missouri and Illinois: Weller, $1218,1221$.

Fern Glen shale, Mississippian, Illinois and Missouri: Fenneman, 392

Fernie shale, Jurassic, British Columbia: Dowling, 350.

Fernvale limestone, Ordovician, Illinois: Savage, 1027. 
Fish Creek beds, Cretaceous, Montana: Douglass, 348.

Fish Creek sandstone, Carboniferous, West Virginia: Hennen, 537 .

Fisbkill limestone, Cambro-Ordovicic, New York: Clarke, 240 .

Flat Rock dolomite, Silurian, Michigan and adjacent: Sherzer and Grabau, 1058.

Flat Rock dolomites, Silurian, Michigan: Lane et al., 733 .

Fleming Inlet series, Triassic, Greenland: Nordenskjöld, 900 .

Florena shales, Carboniferous, Kansas: Haworth and Bennett, 518.

Florence flint, Carboniferous, Kansas: Haworth and Bennett, 518.

Floridian group, Pliocene, Florida: Matson and Clapp, 829.

Floyd shales, Carboniferous, Georgia: Veatch, 1184.

Fordham gneiss, New York: Berkey, 101, 103; Koeberlin, 679.

Forelle limestone, Carbonilerous, Wyoming: Darton and Siebenthal, 313.

Fork Mountain slate, Arkansas: Purdue, 972.

Fort Ancient division, Ordovician, Ohio: Foerste, 413.

Fort Benton formation, Cretaceous, Montana: Douglass, 348 .

Fort Payne chert, Carboniferous, Georgia: Veatch, 1184.

Fort Riley limestone, Carboniferous, Kansas: Haworth and Bennett, 518.

Fort Scott limestone, Carboniferous, Kansas: Haworth and Bennett, 518 .

Fort Union beds, Cretaceous, Montana: Douglass, 348.

Fort Union formation, Eocene, Montana: Stanton, 1094.

Fort Union formation, Eocene, North Dakota: Leonard, 758.

Fort Union formation, Eocene, North Dakota and Montana: Leonard and Smith, 761.

Fort Union formation, Eocene, Wyoming, North and South Dakota, and Montana: Knowlton, 678 .

Fort Union formation, Tertiary, Wyoming: Shaw, 1054; Washburne, 1204; Woodruff, 1283, 1284.

Fort Union formation, Tertiary, Montana: Pepperberg, 949; Smith, 1076; Stone, 1164.

Fountain formation, Pennsylvanian, Colorado: Henderson, 536 .

Fountain formation, Triassic?, Colorado: Martin, 819.

Fox Hills formation, Cretaceous, Colorado: 'Henderson, 536; Martin, 819 .

Fox Hills formation, Cretaceous, Montana: Douglass, 348 .

Fox Hills formation, Cretaceous, North Dakota: Leonard, 758.

Fox Hills sandstone, Cretaceous, South Dakota: Darton, 307; Darton and O'Harra, 312.

Fox Hills (?) sandstone, Cretaceous?, Montana: Smith, 1076 .

Fox Hills sandstone, Cretaceous, Wyoming and South Dakota: Darton, 306.

Fox Hills substage, Cretaceous, Mexico: Aguilera, 10.
Franciscan formation, Jurassic?, California: Arnold, 30, 31; Branner et al., 138.

Franklin limestone, pre-Cambrian, New Jersey: Kümmel, 682.

Franklin limestone formation, pre-Cambrian, New Jersey: Bayley, 86.

Franklin limestone, pre-Cambrian, Pennsylvania: Bascom et al., 75 .

Fulton green shale, Carboniferous, West Virginia: Hennen, 537.

Fuson formation, Cretaceous, South Dakota: Darton, 307; Darton and O'Harra, 312.

Fuson formation, Cretaceous, Wyoming and South Dakota: Darton, 306.

Fusselman limestone, Silurian, Texas: Richardson, 998.

Galesburg shales, Carboniferous, Kansas: Haworth and Bennett, 518 .

Garrard sandstone, Ordovician, Kentucky: Foerste, 413.

Garrison formation, Carboniferous, Kansas: Haworth and Bennett, 518.

Gasconade formation, Cambrian, Missouri: Buckley, 158.

Gaspé sandstone, Devonian, Canada: Williams, 1254.

Genesee shale, Devonian, New York: Luther, 786; Williams, 1254

Geneva limestone, Devonian, Indiana: Kindle and Barnett, 670 .

Genundewa limestone, Devonian, New York: Luther, 786 .

Gila conglomerate, Quaternary, Arizona: Truesdell, 1155.

Gilboy sandstone, Carboniferous, West Virginia: Hennen, 537.

Gilmore sandstone, Carboniferous, West Virginia: Hennen, 537.

Girardeau limestone, Silurian, Illinois and Misșouri: Savage, 1027.

Glendale granite, Tertiary, Colorado: Crawford, 290. Glen Park formation, Devonian, Missouri: Buckley, 158.

Glen Rose formation, Cretaceous, Texas: Hess, $\mathbf{5 5 1 .}$ Globe limestone, Devonian-Carboniferous, Arizona: Truesdell, 1155.

Goodland limestone, Cretaceous, Oklahoma: Taff and Reed, 1132.

Gower limestone, Silurian, Illinois and Iowa: Carman, 198.

Grand Rapids group, Carboniferous, Michigan: Cooper, 285.

Grand Tower, Devonian, Missouri: Buckley, 158.

Grainger formation, Devonian, Virginia: Bassler, 78.

Graneros shale, Cretaceous, South Dakota: Darton, 307.

Graneros shale, Cretaceous, Wyoming and South Dakota: Darton, 306.

Greenbrier limestone, Mississippian, Virginia: Bassler, 78.

Greendale bed, Ordovician, Kentucky: Foerste, 413.

Greenfield dolomite, Silurian, Ohio: Lane ot al., 733; Sherzer and Grabau, 1058.

Greenhorn limestone, Cretaceous, South Dakota: Darton, 307; Darton and O'Harra, 312. 
Greenhorn limestone, Cretaceous, wyoming and South Dakota: Darton, 306.

Green Pond conglomerate, Silurian, New Jersey: Kümmel, 682.

Green River formation, Tertiary, Colorado: Gale, 433; Lee, 743.

Green River formation, Tertiary, Wyoming, Schultz, 1039.

Grenville gneiss, pre-Cambrian, New York: Miller: 867.

Grimes sandstone, Devonian, New York: Luther, 786.

Guanajuato conglomerate, Mexico: Botsford, 129.

Gunnison formation, Jurassic?, Colorado: Lee, 743.

Gunnison formation, Juratrias, Colorado: Spurr, 1091.

Hampton shale, Cambrian, Virginia: Bassler, 78.

Hancock limestone, Devonian, Virginia: Bassler, 78.

Hannibal formation, Mississippian, Missouri: Buckley, 158.

Harpers schist, Cambrian, Pennsylvania: Stose, 1119.

Harpers shale, Cambrian, Virginia: Bassler, 78.

Hardyston quartzite, Cambrian, New Jersey: Kümmel, 682.

Hatch shale and flags, Devonian, New York: Luther, 786.

Hawthorne formation, Oligocene, Florida: Matson and Clapp, 829.

Helderberg limestone, Silurian, Pennsylvania: Stose, 1119

Hell Creek beds, Cretaceous, Montana: Stanton, 1094.

Hell Creek beds, Eocene, Montana: Knowlton, 678 .

Herculean shale member, Tertiary, California: Weaver, 1212.

Herington limestone, Carboniferous, Kansas: Beede, 90 .

Highbridge limestone, Ordovician, Kentucky: Matson, 827.

High Falls formation, Silurian, New Jersey: Kümmel, 682 .

High Point sandstone, Devonian, New York: Luther, 786.

Hoko formation, Pliocene, Washington: Reagan, 989.

Holston marble, Ordovician, Virginia: Bassler, 78.

Honaker limestone, Cambrian, Virginia: Bassler, 78

Hopkinton limestone, Silurian, Illinois and Iowa: Carman, 198.

Hornerstown marl, Cretaceous, New Jersey: Bascom et al., 74, 75; Kümmel, 682 .

Howard limestone, Carboniferous, Kansas: Haworth and Bennett, 518 .

Hudson River (Thebes), Ordovician, Missouri: Buckley, 158.

Hueco limestone, Pennsylvanian, Texas: Richardson, 998.

Hundred sandstone, Carboniferous, West Virginia: Hennen, 537.

Huronian, pre-Cambrian, Ontario: Collins, 276.

Hurry Inlet series, Triassic, Greenland: Nordenskjöld, 900 .

Hygiene sandstone, Cretaceous, Colorado: Henderson, 536.
Hygiene sandstone member, Cretaceous, Colorado: Martin, 819.

Idaho Springs formation, Colorado: Patton, 943

Illinoian drift, Pleistocene, Iowa: Calvin, 187.

Illinoian epoch, Quaternary, Illinois and Missouri: Fenneman, 392.

Illinoian glacial epoch, Quaternary, Illinois and Iowa: Carman, 198.

Illinoian till, Pleistocene, Ontario: Coleman, 269. .

Indian Fields member, Silurian, Kentucky: Foerste, 409.

Inwood limestone, New York: Berkey, 101, 103; Koeberlin, 679.

Iola limestone, Carboniferous, Kansas: Haworth and Bennett, 518 .

Iowan drift, Pleistocene, Iowa: Calvin, 187.

Iowan glacial epoch, Quaternary, Illinois and Iowa: Carman, 198.

Iowan till, Pleistocene, Ontario: Coleman, 269.

Iroquois clay, Pleistocene, Ontario: Coleman, 269.

Irvine formation, Tertiary, Kentucky: Matson, 827.

Ithaca shale member, Devonian, New York: Williams, 1254.

Jacalitos formation, Miocene, California: Arnold, 30 .

Jackfork sandstone, Carboniferous, Oklahoma: Taff, 1130 .

Jackson stage, Eocene, Louisiana and Texas: Harris; 51.2.

Jacksonburg limestone, Ordovician, New Jersey: Kümmel, 682 .

Jacksonville formation, Miocene, Florida: Matson and Clapp, 829.

Jefferson City formation, Cambrian, Missouri: Buckley, 158 .

Jeffersonville limestone, Devonian, Kentucky: Bassler, 80 .

Joachim formation, Ordovician, Missouri: Buckley, 158.

Joliet conglomerate, Pleistocene, Illinois: Goldthwait, 461.

Jolly town sandstone, Carboniferous, West Virginia: Hennen, 537.

Judith River beds, Cretaceous, Montana: Douglass, 348.

Judith River formation, Cretaceous, Montana: Pepperberg, 948, 949; Stone, 1114.

Judith River formation, Cretaceous, Wyoming: Washburne 1204.

Juniata formation, Ordovician, Pennsylvania: Stose, 1119.

Juniata red beds, Ordovician, Pennsylvania: Grabau, 476 .

Kanouse sandstone, Devonian, New Jersey: Kümmel, 682.

Kansan drift, Pleistocene, Iowa: Calvin, 187.

Kansan epoch, Quaternary, Illinois and Missouri: Fenneman, 392.

Kansan glacial epoch, Quaternary, Illinois and Iowa: Carman, 198.

Kansan or pre-Kansan drift, Pleistocene, New Jersey: Kümmel, 682.

Kanwaka shales, Carboniferous, Kansas: Haworth and Bennett, 518 .

Keewatin, pre-Cambrian, Ontario: Collins, 276.

Kendall tuff, Tertiary, Nevada: Ransome, 976. 
- Kennicott formation, Jurassic or Cretaceous, Lamotte formation, Cambrian, Missouri: Buckley, Alaska: Moffit and Maddren, 875.

Keokuk formation, Mississippian, Missouri: Buckley, 158.

Key Largo limestone, Pleistocene, Florida: Sanford, 1025.

Key West oolite, Pleistocene, Florida: Sanford, 1025 .

Kibbey sandstone, Carboniferous, Montana: Fisher, 396.

Kickapoo limestone, Carboniferous, Kansas: Haworth and Bennett, 518 .

Kiger stage, Carboniferous, Kansas: Haworth and Bennett,. 518 .

Kimmswick formation, Ordovician, Missouri: Buckley, 158.

Kimmswick limestone, Ordovician, Illinois: Savage, 1027.

Kimmswick limestone, Ordovician, Missouri: Weller, 1218.

Kinderhook formation, Mississippian, Illinois and Missouri: Fennemạn, 392.

Kingsbury conglomerate, Eocene, Wyoming: Knowlton, 678 .

Kingsbury conglomerate, Tertiary, Wyoming: Stanton, 1094

Kingston or Port Ewen beds, Devonian, New Jersey: Kümmel, 682 .

Kirkwood formation, Tertiary, New Jersey: Bascom et al., 74, 73; Kümmel, 682

Kittatinny limestone, Cambrian, New Jersey: Kümmel, 682 .

Knob (Riverside) sandstone, Mississippian, Kentucky: Bassler, 80

Knobstone group, Mississippian, Kentucky: Bassler, 80 .

Knox dolomite, Cambro-Ordovician, Virginia: Bassler, 78.

Knox dolomite, Ordovician, Georgia: Veatch, 1184.

Knoxville formation, Cretaceous, California: Arnold, 31; Branner et al., 138.

Knoxville-Chico rocks, Cretaceous, California: Arnold, 30; Johnson, 631 .

Kootanie, Cretaceous, Canada: Dowling, 350.

Kootanie formation, Cretaceous, Alberta: Dowling, 352.

Kootenai formation, Cretaceous, Montana: Calvert, 185; Fisher, 396, 397; Stone, 1114.

Labette shales, Carboniferous, Kansas: Haworth and Bennett, 518 .

Ladore shales, Carboniferous, Kansas: Haworth and Bennett, 518 .

Lafayette formation, Illinois and Missouri: Fenneman, 392 .

Lafayette formation, Pliocene, Florida: Matson and Clapp, 829

Lafayette formation, Tertiary, Georgia: Veatch, 1184.

Lafayette formation, Tertiary, New Jersey: Bascom $t$ a al., 74 .

Lafayette gravels, Tertiary, Missouri: Buckley, 158.

Lake Valley beds, Mississippian: Weller, 1218.

Lakota sandstone, Cretaceous, South Dakota: Darton, 307; Darton and O'Harra, 312.

Lakota sandstone, Cretaceous, Wyoming and South Dakota: Darton, 306.

La Luz schists, Mexico: Botsford, 129. 158.

Lance Creek beds, Cretaceous, Wyoming: Stanton, 1094.

Lance Creek beds, Eocene, Wyoming: Knowlton, 678.

Lane shales, Carboniferous, Kansas: Haworth and Bennett, 518.

Lanoria quartzite, pre-Cambrian, Texas: Richardson, 998.

Laramie formation, Colorado: George and Crawford, 446 .

Laramie formation, Cretaceous, Colorado: Gale, 433; Henderson, 536; Martin, 819.

Laramie formation, Cretaceous, Great Plains and Rocky Mountain region: Cross, 294

Laramie, Cretaceous, Montana: Douglass, 348; Stone, 1114.

Laramie, Cretaceous, Mexico: Aguilera, 10.

Laramie formation, Cretaceous, New Mexico: Gardner, 436 .

Laramie formation, Cretaceous, Wyoming: Ball, 57; Schultz, 1039; Smith, 1077; Washburne, 1204; Woodruff, 1284

Laramie, Colorado, Wyoming, and Montana: Peale, 944.

Laramie? formation, Cretaceous, Wyoming and South Dakota: Darton, 306.

Las Vigas formation, Mexico: Burrows, 171.

Laurentian, pre-Cambrian, Ontario: Collins, 276.

Lawrence shales, Carboniferous, Kansas: Haworth and Bennett, 518; Yates, 1295.

Leclaire limestone, Silurian, Illinois and Iowa: Carman, 198.

Lecompton shales, Carboniferous, Kansas: Haworth and Bennett, 518 .

Leda clay, Pleistocene, Ontario: Coleman, 269.

Leithsville formation, Cambrian, Pennsylvania: Wherry, 1229.

Le Roy shales, Carboniferous, Kansas: Haworth and Bennett, 518.

Levyville formation, Oligocene, Florida: Matson and Clapp, 829.

Lewis shale, Cretaceous, Colorado: Gale, 433.

Lewis shale, Cretaceous, New Mexico: Gardner, 436.

Lewis shale, Cretaceous, Wyoming: Ball, 57; Schultz, 1039; Stanton, 1094.

Lewistown limestone, Silurian-Devonian, Virginia: Bassler, 78.

Lexington limestone, Ordovician, Kentucky: Matson, 827.

Liberty Hall formation, Ordovician, Virginia: Bassler, 78 .

Light-house granite, Connecticut: Ward, 1201.

Linietta claýs, Mississippian, Kentucky: Morse and Foerste, 887.

Livingston formation, Tertiary, Montana: Stone 1114.

Lockatong beds, Triassic, New Jersey: Kümmel, 682.

Lockatong formation, Triassic, Pennsylvania: Bascom et al., 74, 75.

Logan formation, Carboniferous, Ohio: Carney, 200.

Logan formation, Mississippian, Ohio and Kentucky: Morse and Foerste, 887.

Lone Tree white layer, Eocene, Wyoming: Matthew, 834. 
Longwood shale, Silurian, New Jersey: Kümmel, 682.

Lookout sandstone, Carboniferous, Georgia: Veatch, 1184.

Lorraine beds, Ordovician, New York: Miller, 867.

Losee gneiss, New Jersey: Bayley, 86.

Losee gneiss, pre-Cambrian, New Jersey: Kümmel, 682.

Lostmans River limestone, Pleistocene, Florida: Matson and Clapp, 829; Sanford, 1025.

Loudon formation, Cambrian, Virginia: Bassler, 78.

Louisiana formation, Mississippian, Missouri: Buckley, 158

Louisvllle formation, Silurian, Kentucky: Bassler, 80.

Louisville limestone, Silurian, Indiana: Kindle and Barnett, 670 .

Lowville, Ordovician, New York: Graban, 472.

Lowville limestone, Ordovician, New York: Miller, 867.

Lucas dolomite, Silurian, Michigan and Ohio: Sherzer and Grabau, 1058.

Lucas dolomite, Silurian, Ohio: Lane et al., 733.

Ludlowville shale, Devonian, New York: Luther, 786.

Luta limestone, Carboniferous, Kansas: Beede, 90.

Lykins formation, Permo-Triassic?, Colorado: Henderson, 536

Lykins formation, Triassic; Colorado: Martin, 819. Lyons formation, Pennsylvanian, Colorado: Henderson, 536 .

Lyons sandstone, Triassic, Colorado: Martin, 819.

McAdam formation, Silurian, Nova Scotia: Twenhofel, 1158.

Madera limestone, Pennsylvanian, New Mexico: Lee, 745.

Madison limestone, Carboniferous, Montana: Fisher, 396, 397.

Madison limestone, Mississippian, Montana: Calvert, 185 .

Magdalenagroup, Pennsylvanian, New Mexico: Lee, 745.

Magothy formation, Cretaceous, Atlantic coastal plain: Bibbins, 113 .

Magothy formation, Cretaceous, New Jersey: Bascom et al., 74, 75; Kümmel, 682.

Mahoning sandstone, Carboniferous, Pennsylvania: Raymond, 983.

Malpais basalt, Tertiary, Nevada: Ransome, 976.

Manasquan formation, Cretaceous, New Jersey: Bascom et al., 75.

Manasquan marl, Cretaceous, New Jersey: Kümmel, 682 .

Manatee River marl, Oligocene, Florida: Matson and Clapp, 829.

Mancos shale, Cretaceous, Colorado: Gale, 433: George and Crawford, 446; Lee, 743.

Mancos shale, Cretaceous, Colorado and Utah: Richardson, 1000.

Mancos shale, Cretaceous, New Mexico: Gardner, 436.

Manhattan schist, New York: Berkey, 101, 103; Koeberlin, 679

Manitoban series, Devonian, Manitoba: Dowling, 350 .

Manlius limestone, Silurian, New Jersey: Kümmel 682
Manlius limestone, Silurian, New York: Luther, 786 .

Mannington sandstone, Carboniferous, West Virginia: Hennen, 537.

Manzano group, Pennsylvanian, New Mexico: Lee, 745 .

Maquoketa shale, Ordovician, Illinois and Iowa: Carman, 198.

Marcellus shale, Devonian, New Jersey: Kümmel, 682.

Marcellus shale, Devonian, New York: Luther, 786. Marietta sandstones, Carboniferous, West Virginia: Hennen, 537.

Marianna limestone, Oligocene, Florida: Matson and Clapp, 829 .

Marion limestone, Carboniferous, Kansas: Haworth and Bennett, 518.

Marion stage, Carboniferous, Kansas: Beede, 90.

Maroon formation, upper Carboniferous, Colorado: Spurr, 1091.

Marmaton stage, Carboniferous, Kansas: Haworth and Bennett, 518 .

Marshall sandstone, Carboniferous, Michigan: Cooper, 285.

Marshalltown clay-marl, Cretaceous, New Jersey: Kümmel, 682 .

Marshalltown formation, Cretaceous, New Jersey: Bascom et al., 74, 75.

Martinsburg shale, Ordovician, New Jersey: Kümmel, 682 .

Martinsburg shale, Ordovician, Pennsylvania: Stose, 1119.

Martinsburg shale, Ordovician, Virginia: Bassler, 78 .

Maryville limestone, Cambrian, Virginia: Bassler, 78.

Massanutten sandstone, Ordovician, Virginia: Bassler, 78 .

Matawan group, Cretaceous, New Jersey: Bascom et al., 74, 75 .

Matfield shales, Carboniferous, Kansas: Haworth and Bennett, 518 .

Maysville formation, Ordovician, Kentucky: Matson, 827.

Meda rhyolite, Tertiary, Nevada: Ransome, 976.

Medora group of lignite beds, Eocene, North Dakota: Leonard and Smith, 761.

Merced formation, Pliocene, California: Branner et al., 138.

Merchantville clay, Cretaceous, New Jersey: Bascom et al., 74, 75; Kümmel, 682 .

Mesaverde formation, Cretaceous, Colorado: Gale, 433; Lee, 743 .

Mesaverde formation, Cretaceous, Colorado and Utah: Richardson, 1000.

Mesaverde formation, Cretaceous, New Mexico: Gardner, 436.

Mesaverde formation, Cretaceous, Wyoming: Ball, 57; Schultz, 1039; Smith, 1077; Stanton, 1094.

Miami oolite, Pleistocene, Florida: Matson and Clapp, 829; Sanford, 1025.

Michigan series, Carboniferous, Michigan: Cooper, 285.

Midway formation, Eocene, Louisiana: Harris, $\mathbf{5 1 2 .}$

Midway formation, Tertiary, Georgia: Veatch, 1184 Million bed, Ordovician, Kentucky: Foerste, 413.

Milltown andesite. Tertiary, Nevada: Ransome, 976. 
Minnekahta limestone, Carboniferous, South Dakota: Darton, 307; Darton and O'Harra, 312.

Minnekahta limestone, Carboniferous, Wyoming and South Dakota: Darton, 306.

Minnelusa sandstone, Carboniferous, South Dakota: Darton, 307; Darton and O'Harra, 312.

Minnelusa sandstone, Carboniferous, Wyoming and South Dakota: Darton, 306.

Minnewaste limestone, Cretaceous, South Dakota: Darton, 307.

Mira basalt, Tertiary, Nevada: Ransome, 976.

Missouri Mountain formation, Ordovician, Arkansas: Purdue, 973.

Missouri Mountain slate, Arkansas: Purdue, 972.

Moccasin limestone, Ordovician, Virginia: Bassler, 78.

Monmouth group, Cretaceous, New Jersey: Bascom et al., 74, 75 .

Monongahela series, Carboniferous, West Virginia: Hennen, 537.

Monroan, Silurian, Michigan, Ohio, and Canada: Grabau, 472.

Monroe formation, Silurian, Michigan and adjacent: Sherzer and Grabau, 1058.

Monroe formation, Silurian, Michigan, Ohio, and New York: Lane et al., 733 .

Montalto quartzite member, Cambrian, Pennsylvania: Stose, 1119.

Montana formation, Cretaceous, Wyoming: Shaw, 1054.

Montana group, Cretaceous, Colorado: Henderson, 536.

Montana group, Cretaceous, Montana: Calvert, 185; Fisher, 397; Pepperberg, 949; Stone, 1114.

Montana group, Cretaceous, South Dakota: Todd, 1146.

Montana group, Cretaceous, W yoming: Darton and Siebenthal, 313; Woodruff, 1284.

Montana stage, Cretaceous, Mexico: Aguilera, 10.

Monterey shale, Miocene, California: Branner et al., 138.

Monterey shales, Miocene, California: Johnson, 631.

Montezuma granite, Colorado: Patton, 943.

Montoya limestone, Ordovician, Texas: Richardson, 998 .

Mora sandstones, New Mexico: Keyes, 654.

Morena rhyolite, Tertiary, Nevada: Ransome, 976.

Morrison formation, Cretaceous, Colorado: Henning, 538.

Morrison formation, Cretaceous, Wyoming: Darton and Siebenthal, 313 .

Morrison formation, Cretaceous, Wyoming and South Dakota: Darton, 306.

Morrison formation, Jurassic, Colorado: Henderson, 536.

Morrison formation; Jurassic, Montana: Calvert, 185; Fisher, 397 .

Morrison formation, Jurassic or Cretaceous, Colorado: Martin, 819 .

Morrison shale, Cretaceous, South Dakota: Darton, 307; Darton and O'Harra, 312.

Morrison shale, Jurassic ?, Montana: Fisher, 396.

Moscow shale, Devonian, New York: Luther, 786.

Mound Valley limestone, Carboniferous, Kansas: Haworth and Bennett, 518.

Mount Laurel sand, Cretaceous, New Jersey: Bascom et al., 74,75; Kümmel, 682.
Mount Morris limestone, Carboniferous, West Virginia: Hennen, 537.

Mount Sicker series, Mesozoic, British Columbia: Clapp, 228.

Mowry member, Cretaceous, Wyoming and South Dakota: Darton, 306.

Moydart formation, Silurian, Nova Scotia: Twenhofel, 1158.

Murat limestone, Ordovician, Virginia: Bassler, 78.

Nashua marl, Pliocene, Florida: Matson and Clapp, 829.

Nastapoka group, Canada: Young, 1297.

Nation River formation, Carboniferous, Alaska: Prindle, 969.

Natural Bridge limestone, Cambro-Ordovician, Virginia: Bassler, 78.

Navarro fcimation, Cretaceous, Texas: Gordon, 465 .

Navesink marl, Cretaceous, New Jersey: Bascom et al., 74, 75; Kümmel, 682 .

Nazareth cement rock, Ordovician, Pennsylvania: Wherry, 1229 .

Nebraskan drift sheet, Pleistocene, Iowa: Shimek, 1060.

Neosho member, Carboniferous, Kansas: Haworth and Bennett, 518 .

Neva limestone, Carboniferous, Kansas: Haworth and Bennett, 518 .

New Albany shale, Devonian, Kentucky: Bassler, 80.

Newark group, Triasșic, Pennsylvania: Bascom et al., 74,75 .

Newland formation, Algonkian, Idaho and Montana: Calkins, 181.

Newman limestone, Mississippian, Virginia: Bassler, 78.

New Providence shale, Mississippian, Indiana and Kentucky: Weller, 1218.

New Providence shale, Mississippiian, Kentucky: Bassler, 80.

New Scotland beds, Devonian, New Jersey: Kümmel, 682 .

Niagara limestone, Silurian, Illinois and Iowa: Carman, 198.

Niagara (Bainbridge), Silurian, Missouri: Buckley, 158

Niagaran, Silurian: Grabau, 472.

Niagaran limestone, Silurian, Kentucky: Bassler, 80.

Nicholas bed, Ordovician, Kentucky: Foerste, 413. Nicholas beds, Ordovician, Kentucky and Ohio: Foerste, 412.

Nikolai greenstone, Alaska: Moffit and Maddren, 875 .

Nineveh sandstone, Carboniferous, West Virginia: Hennen, 537.

Niobrara, Cretaceous, Canada: Dowling, 350 .

Niobrara, Cretaceous, North Dakota: Barry and Melsted, 70.

Niobrara formation, Cretaceous, Colorado: Henderson', 536.

Niobrara limestone, Cretaceous, Colorado: Martin, 819

Niobrara formation, Cretaceous, South Dakota: Darton, 307; Darton and O'Harra, 312; Todd, 1146. Niobrara formation, Cretaceous, Wyoming: Darton and Siebenthal, 313 . 
Niobrara formation, Cretaceous, Wyoming and South Dakota: Darton, 306.

Nipissing clay, Pleistocene, Ontario: Coleman, 269.

Nisky formation, Ordovician, Pennsylvania: Wherry, 1229.

Nolichucky shale, Cambrian, Virginia: Bassler, 78.

Oak Grove sand member, Oligocene, Florida: Matson and Clapp, 829.

Ocala limestone, Oligocene, Florida: Matson and Clapp, 829.

Ocheesee beds, Oligocene, Florida: Matson and Clapp, 829.

Octoraro schist, Ordovician, Pennsylvania: Bascom et al., 74,75 .

Ogalalla formation, Pliocene, Nebraska: Matthew and Cook, 840 .

Ohio shale, Devonian, Kentucky: Matson, 827.

Ohio shale, Devonian and Mississippian, Kentucky: Morse and Foerste, 887.

Ohio Creek formation, Tertiary, Colorado: Lee, 743 .

Ojinaga formation, Mexico: Burrows, 171.

Oldham limestone, Silurian, Kentucky: Foerste, 409.

Olentangy shale, Devonian, Ohio: Stauffer, 1096.

Onondaga limestone, Devonian, New Jersey: Kümmel, 682 .

Onondaga limestone; Devonian, New York: Luther 786.

Opeche formation, Carboniferous, South Dakota: Darton, 307; Darton and O'Harra, 312.

Opeche formation, Carboniferous, Wyoming and South Dakota: Darton, 306.

Orchard Creek shale, Ordovician, Illinois: Savage, 1027.

Oread limestone, Carboniferous, Kansas: Haworth and Bennett, 518 .

Oriskany formation, Devonian, New Jersey: Kümmel, 682 .

Oriskany formation, Devonian, Pennsylvania: Stose, 1119.

Oriskany sandstone, Devonian, New York: Luther, 786.

Osage formation, Mississippian, Missouri: Buckley, 158.

Osage limestone, Mississippian, Illinois and Missouri: Fenneman, 392

Otter shale, Carboniferous, Montana: Fisher, 396.

Ouachita shale, Ordovician: Purdne, 972.

Ouray limestone, Devonian, Colorado: Kindle, 666.

Pahasapa limestone, Carboniferous, South Dakota: Darton, 307.

Pahasapa limestone, Carboniferous, Wyoming and South Dakota: Darton, 306.

Paint Lick bed, Ordovician, Kentucky: Foerste, 413.

Palm Beach limestone, Pleistocene, Florida: Sanford, 1025 .

Pamelia (Stones River) formation, Ordovician, New York and Canada: Clarke, 240.

Panola formation, Silurian and Devonian, Kentucky: Matson, 827.

Paonia shale, Cretaceous, Colorado: Lee, 743.

Paris bed, Ordovician, Kentucky: Foerste, 413.

Parkman sandstone, Cretaceous, Wyoming: Stanton, 1094.

Parting quartziteseries, Devonian, Colorado: Spurr, 1091.
Paskapoo, Tertiary, Canada: Dowling, 350.

Paskapoo formation, Tertiary, Alberta: Dowling, 352.

Patapsco formation, Cretaceous, New Jersey: Bas com et al., 74.

Patriot limestone, Carboniferous, Ohio: Condit, 280.

Pawnee limestone, Carboniferous, Kansas: Haworth and Bennett, 518 .

Peace Creek bone bed, Pliocene, Florida: Matson and Clapp, 829.

Pearisburg limestone, Ordovician, Virginia: Bassler, 78.

Pearl shales, Carboniferous, Kansas: Beede, 90.

Peninsular limestone, Oligocene, Florida: Matson and Clapp, 829.

Pennington shale, Mississippian, Virginia: Bassler, 78.

Pensauken formation, Pleistocene, New Jersey: Kümmel, 682 .

Pensauken formation, Quaternary, Delaware, Pennsylvania, and New Jersey: Bascom et al., 74, 75 .

Peorian interglacial epoch, Quaternary, Illinois and Iowa: Carman, 198.

Peorian interglacial interval, Pleistocene, Iowa: Calvin, 187.

Pequanac shale, Devonian, New Jersey: Kümmel, 682.

Pierre formation, Cretaceous, Colorado: Henderson, 536.

Pierre formation, Cretaceous, Montana: Douglass, 348.

Pierre shale, Cretaceous, Montana: Smith, 1076.

Pierre shale, Cretaceous, North Dakota: Barry and Melsted, 70; Leonard, 758.

Pierre shale, Cretaceous, South Dakota: Darton, 307; Darton and O'Harra, 312; Todd, 1146.

Pierre shale, Cretaceous, Wyoming and South Dakota: Darton, 306.

Pinal schist, pre-Cambrian, Arizona: Truesdell, 1155.

Pine Creek limestone, Carboniferous, Pennsylvania: Raymond, 983.

Piney formation, Cretaceous, Wyoming: Knowlton, 678; Stanton, 1094.

Pinguico rhyolites, Mexico: Botsford, 129.

Pittsburg limestone, Carboniferous, Ohio: Condit, 280.

Pittsburg sandstone, Carboniferous, West Virginia: Hennen, 537.

Plattin formation, Ordovician, Missouri: Buckley, 158.

Pleasanton formation, Carboniferous, Iowa: Lees, 751.

Pleasanton shales, Carboniferous, Kansas: Haworth and Bennett, 518.

Plomosas formation, Mexico: Burrows, 171.

Plum Creek clay, Silurian, Kentucky: Foerste, 409.

Pochuck gneiss, pre-Cambrian, New Jersey: Kümmel, 682 .

Pochuck gneisses, New Jersey: Bayley, 86.

Point Pleasant beds, Ordovician, Ohio: Foerste, 412, 413.

Polk Creek shale, Ordovician, Arkansas: Purdue, 972, 973.

Portage formation, Devonian, New York: Williams, 1254. 
Portage shales, Devonian, Pennsylvania: Stose $_{8}$ 1119.

Port Ewen (Kingston) beds, Devonian, New Jersey: Kümmel, 682.

Potomac group, Cretaceous, New Jersey: Bascom et al., 74, 75.

Potọsi formation, Cambrian, Missouri: Buckley, 158.

Pottawatomie stage, Carboniferous, Kansas: Haworth and Bennett, 518 .

Pottsville formation, Carboniferous, Ohio: Carney, 200.

Poughquag quartzite, New York: Clarke, 240.

Poxino Island shale, Silurian, New Jersey: Kümmel, 682.

Pozo formation, Tertiary, Nevada: Ransome, 976.

Pre-Kansan drift, Pleistocene, Iowa: Calvin, 187.

Prichard formation, Algonkian, Idaho and Montana: Calkins, 181.

Proctor formation, Cambrian, Missouri: Buckley, 158.

Proctor sandstones, Carboniferous, West Virginia: Fennen, 537.

Prout limestone, Devonian, Ohio; Stauffer, 1096.

Providence sand, Cretaceous, Georgia: Veatch, 1184.

Pulaski beds, Tertiary, Oregon: Dall, 300.

Purisima formation, Miocene, California: Branner et al., 138 .

Put in Bay dolomites, Silurian, Ohio: Lane et al., 733; Sherzer and Grabau, 1058.

Quadrant formation, Carboniferous, Montana: Fisher, 396, 397.

Quadrantformation, Pennsylvanian?, Montana: Calvert, 185.

Quercan sandstone, Tertiary, California: Weaver, 1212.

Quillayute formation, Pliocene, Washington: Reagan, 989.

Quinaielt formation, Pliocene, Washington: Reagan, 989.

Rabbit Spring formation, Tertiary, Nevada: Ransome, 976 .

Raft River formation, Pliocene, Washington: Reagan, 989 .

Raisin River dolomites, Silurian, Ohio and Michigan: Lane et al., 733; Sherzer and Grabau, 1058.

Rancocas group, Cretaceous, New Jersey: Bascom et al., 74, 75.

Raritan formation, Cretaceous, New Jersey: Bascom et al., 74, 75; Kümmel, 682.

Ravalli group, Algonkian, Idaho and Montana: Calkins, 181.

Ravenswood granodiorite, New York: Berkey, 101.

Red Bank sand, Cretaceous, New Jersey: Bascom et al., 75 .

Red Bank sạnd, Cretaceous, New Jersey: Kümmel, 682.

Redstone limestone, Carboniferous, West Virginia: Hennen, 537.

Renfroes marl, Cretaceous, Georgia: Veatch, 1184.

Revett formation, Algonkian, Idaho and Montana: Calkins, 181.

Rhinestreet shale, Devonian, New York: Luther, 786.

Richmond formation, Ordovician, Kentucky: Matson, 827 .
Ripley formation, Cretaceous, Georgia: Veatch, 1184.

Riverside. See Knob sandstone.

Roan gneiss, Archean, North and South Carolina: Pratt and Sterrett, 968.

Rockford (Goniatite) limestone, Mississippian, Kentucky: Bassler, 80 .

Rockmart slate, Silurian, Georgia: Veatch, 1184.

Rockwood formation, Silurian, Georgia: Veatch, 1184.

Rogersville shale, Cambrian, Virginia: Bassler, 78.

Rollins sandstone, Cretaceous, Colorado: Lee, 743.

Rome formation, Cambrian, Georgia: Veatch, 1184.

Romney or Chattanooga shale, Devonian, Virginia: Bassler, 78.

Romney shales, Devonian, Pennsylvania: Stose, 1119.

Rondout limestone, Silurian, New Jersey: Kümmel, 682 .

Rondout waterlime, Silurian, New York: Luther, 786.

Roubidoux formation, Cambrian, Missouri: Buckley, 158.

Ruby formation, Tertiary, Colorado: Lee, 743.

Rush Run sandstone, Carboniferous, West Virginia:

Hennen, 537,

Russell formation, Cambrian, Virginia: Bassler, 78.

Rutledge limestone, Cambrian, Virginia: Bassler, 78.

Sabine stage, Eocene, Louisiana and Texas: Harris, 512 .

Ste. Genevieve formation, Mississippian, Missouri: Buckley, 158

St. Joe marble, Mississippian, Arkansas: Weller, 1218.

St. Louis formation, Mississippian, Missouri: Buckley, 158.

St.. Louis limestone, Mississippian, Illinois and Missouri: Fenneman, 392.

St. Regis formation, Algonkian, Idaho and Montana: Calkins, 181.

St. Peter sandstone, Ordovician, Kentucky: Matson, 827.

St. Peters formation, Ordovician, Missouri: Buckley, 158.

Sage Creek white layer, Eocene, Wyoming: Matthew, 834 .

Saginaw formation, Carboniferous, Michigan: Cooper, 285.

Salinan, Silurian: Grabau, 472.

Salt Fork stage, Carboniferous, Kansas: Haworth and Bennett, 518

Saluda bed, Ordovician, Indiana and Kentucky: Foerste, 413.

San Andreas limestone, Pennsylvanian, New Mexico: Lee, 745.

Sandia formation, Pennsylvanian, New Mexico: Lee, 745 .

Sandstorm rhyolite, Tertiary, Nevada: Ransome, 976.

Sangamon interglacial epoch, Quaternary, Illinois and Iowa: Carman, 198.

Sangamon interglacial interval, Pleistocene, Iowa and Illinois: Calvin, 187

San Lorenzo formation, Oligocene, California: Branner et al., 138. 
San Pablo formation, Tertiary, California: Weaver, 1212.

Santa Fe granite, Colorado: Patton, 943.

Santa Margarita formation, California: Johnson, 631. Santa Margarita formation, Miocene, California: Branner et al., 138.

Santa Margarita? formation, Miocene, California: Arnold, 30.

Satanka shale, Carboniferous, Wyoming: Darton and Siebenthal, 313.

Saxicava sand, Pleistocene, Ontario: Coleman, 269. Scarboro beds, Pleistocene, Ontario: Coleman, 269. Scranton shales, Carboniferous, Kansas: Haworth and Bennett, 518 .

Sellersburg formation, Devonian, Kentucky: Bassler, 80 .

Senecan, Devonian, New York: Luther, 786.

Sentinel Butte group of lignite beds, Eocene, North Dakota: Leonard and Smith, 761.

Severy shales, Carboniferous, Kansas: Haworth and Bennett, 518.

Sevier shale, Ordovician, Virginia: Bassler, 78.

Sewickley sandstone, Carboniferous, West Virginia: Hennen, 537.

Sexton Creek limestone, Silurian, Illinois and Missouri: Savage, 1027.

Shady (Sherwood-Tomstown) limestone, CambroOrdovician, Virginia: Bassler, 78.

Shark River marl, Ėocene, New Jersey: Kümmel, 682

Sharon member, Carboniferous, Ohio: Carney, 200.

Shawangunk conglomerate, Silurian, New Jersey: Kümmel, 682 .

Shawangunk conglomerate, Silurian, Pennsylvania: Grabau, 476.

Shawnee stage, Carboniferous, Kansas: Haworth and Bennett, 518 .

Sheep Creek beds, Miocene, Nebraska: Matthew and Cook, 840.

Shenandoah group, Cambro-Ordovician, Virginia: Bassler, 78.

Shenandoah limestone, Cambro-Ordovician, Pennsylvania: Bascom et al., 74, 75 .

Sherburne flagstone member, Devonian, New York: Williams, 1254.

Shoal River marl member, Oligocene, Florida: Matson and Clapp, 829.

Shoshone group, Cretaceous, Rocky Mountain region: Cross, 294.

Siebert formation, Tertiary, Nevada: Ransome, 976.

Silver Creek hydraulic limestone, Devonian, Kentucky: Bassler, 80.

Skaneateles shale, Devonian, New York: Luther, 786.

Skunnemunk conglomerate, Devonian, New Jersey: Kümmel, 682

Slatington shale, Ordovician, Arkansas: Purdue, 973.

Snake Creek beds, Pliocene, Nebraska: Matthew and Cook, 840 .

Sopchoppy limestone, Oligocene, Florida: Matson and Clapp, 829.

Spearfish formation, Triassic, South Dakota: Darton and O'Harra, 312.

Spearfish formation, Triassic?, South Dakota, Darton, 307.
Spearfish formation, Triassic?, W yoming and South Dakota: Darton, 306.

Spearhead rhyolite, Tertiary, Nevada: Ransome, 976.

Spergen, Mississippian, Missouri: Buckley, 158.

Spergen limestone, Mississippian, Illinois and Missouri: Fenneman, 392.

Spoon Butte beds, Tertiary, Nebraska: Peterson, 951

Standley shale, Carboniferous, Oklahoma: Taff, 1130.

Stanley shale, Carboniferous, Arkansas: Purdue, 972.

Stanton limestone, Carboniferous, Kansas: Haworth and Bennett, 518 .

Stockton beds, Triassic, New Jersey: Kümmel, 682 . Stockton formation, Triassic, Pennsylvania: Bascom et al., 74, 75 .

Stonehouse formation, Silurian, Nova Scotia: Twenhofel, 1158.

Stones River formation, Ordovician, Virginia: Bassler, 78.

Stones River limestone, Ordovician, Pennsylvania: Stose, 1119.

Stormville sandstone, Devonian, New Jersey: Kümmel, 682 .

Stringtown shale, Ordovician, Arkansas: Purdue, 972

Striped Peak formation, Algonkian, Idaho and Montana: Calkins, 181.

Sub-Aftonian drift, Pleistocene, Iowa: Calvin, 187.

Sulphur Springs formation, Devonian, Missouri: Buckley, 158.

Sumner stage, Carboniferous, Kansas: Haworth and Bennett, 518 .

Sunbury formation, Carboniferous, Ohio: Carney, 200.

Sunbury shale, Mississippian, Ohio and Kentucky: Morse and Foerste, 887.

Sundance formation, Jurassic, Colorado: Henderson, 536 .

Sundance formation, Jurassic, South Dakota: Darton, 307; Darton and O'Harra, 312.

Sundance formation, Jurassic, Wyoming: Darton and Siebenthal, 313.

Sundance formation, Jurassic, Wyoming and South Dakota: Darton, 306.

Sylvania sandstone, Silurian, Michigan: Lane et al., 733.

Sylvania sandstone, Silurian, Michigan and adjacent: Sherzer and Grabau, 1058.

Tampa formation, Oligocene, Florida: Matson and Clapp, 829.

Taylor formation, Cretaceous, Texas: Gordon, 465.

Taylor sandstone, Carboniferous, West Virginia: Hennen, 537.

Tecumseh shales, Carboniferous, Kansas: Haworth and Bennett,' 518 .

Tejon formation, Eocene, California: Arnold, 30; Johnson, 631.

Thebes sandstone, Ordovician, Illinois: Savage, 1027.

Tichenor limestone, Devonian, New York: Luther, 786.

Tinton bed, Cretaceous, New Jersey: Kümmel, 682 . Tishomingo granite, Oklahoma: Taff and Reed, 1132. 
Tomstown limestone, Cambrian, Pennsylvania: Stose, 1119.

Topeka limestones, Cärboniferous, Kansas: Haworth and Bennett, 518 .

Toronto formation, Pleistocene, Ontario: Coleman, 269.

Trenton formation, Ordovician, New York: Miller, 867.

Trenton limestone, Ordovician, New York: Miller, 867.

Trentonian, Ordovician: Grabau, 472.

Tribune formation, Mississippian, Missouri: Buckley, 158.

Trinity sand, Cretaceous, Oklahoma: Taff and Reed, 1132.

Truckee formation, Tertiary, Nevada: Anderson, 25.

Tulare formation, Pliocene-Pleistocene, California: Arnold, 30 .

Tully limestone, Devonian, New York: Luther, 786.

Tunnel Point beds, Tertiary, Oregon: Dall, 300.

Tuscaloosa formation, Cretaceous, Georgia: Veatch, 1184.

Tuscarora sandstone, Silurian, Pennsylvania: Grabau, 476; Stose, 1119.

Tymochtee shales and limestones, Silurian, Ohio: Lane et al., 733.

Tyrone beds, Ordovician, Pennsylvania: Grabau, 472.

Ulsterian, Devonian, New York: Luther, 786.

Uniontown sandstone, Carboniferous, West Virginia: Hennen, 537.

Unicoi sandstone, Cambrian, Virginia: Bassler, 78.

- Unkpapa sandstone, Jurassic, South Dakota: Darton, 307; Darton and O'Harra, 312.

Unkpapa sandstone, Jurassic, Wyoming and South Dakota: Darton, 306.

Utica shale, Ordovician: Grabau, 472.

Utica shale formation, Ordovician, New York: Miller, 867.

Vancouver series, Triassic, British Columbia: Clapp, 228.

Vaqueros formation, Miocene, California: Arnold, 30; Branner et al., 138; Johnson, 631.

Vicksburg group, Oligocene, Florida: Matson and Clapp, 829 .

Vicksburg stage, Oligocene, Louisiana and Texas: Harris, 512.

Vicksburg-Jackson formation, Tertiary, Georgia: Veatgh, 1184

Victoria series, Devonian, British Columbia: Clapp, 228.

Vilas shales, Carboniferous, Kansas: Haworth and Bennett, 518.

Vincentown sand, Cretaceous, New Jersey: Bascom et al., 74, 75; Kümmel, 682.

Vindicator rhyolite, Tertiary, Nevada: Ransome, 976.

Wabaunsee stage, Carboniferous, Kansas: Haworth and Bennett, 518 .

Waco limestone, Silurian, Kentucky: Foerste, 409.

Wagonwheel formation, Oligocene?, California: Johnson, 631.

Walden sandstone, Carboniferous, Georgia: Veatch, 1184.

Waldo formation, Oligocene, Florida: Matson and Clapp, 829.
Waldron shale, Silurian, Indiana: Kindle and Barnett, 670 .

Walnut shales, Carboniferous, Kansas: Haworth and Bennett, 518 .

Wappinger limestone, New York: Clarke, 240.

Warren gravels, Pleistocene, Ontario: Coleman, 269.

Warsaw formation, Mississippian, Illinois and Missouri: Fenneman, 392.

Warsaw formation, Mississippian, Missouri: Buckley, 158.

Wasatch formation, Tertiary, Colorado: Gale, 433.

Wasatch formation, Tertiary, Wyoming: Schultz, 1039; Smith, 1077; Washburne, 1204.

Washakie formation, Tertiary, Wyoming: Granger, 482; Sinclair, 1065.

Washington limestones, Carboniferous, West Virginia: Hennen, 537.

Washington sandstone, Carboniferous, West Virginia: Hennen, 537.

Wautaga (Buena Vista) shale, Cambrian, Virginia: Bassler, 78.

Wautaga (Waynesboro-Buena Vista) formation, Cambro-Ordovician, Virginia: Bassler, 78.

Waverly formation, Mississippian, Ohio and Kentucky: Morse and Foerste, 887.

Waverly shale, Carboniferous, Kentucky: Matson, . 827.

Waynesboro formation, Cambrian, Pennsylvania: Stose, 1119.

Waynesburg limestone, Carboniferous, West Virginia: Hennen, 537.

Waynesville bed, Ordovician, Ohio: Foerste, 413.

Weber formation, Carboniferous, Colorado: Spurr, 1091.

Weisner quartzite, Cambrian, Georgia: Veatch, 1184.

Wellsburg sandstone member, Devonian, New York: Williams, 1254.

Wenonah sand, Cretaceous, New Jersey: Bascom et al., 74, 75; Kümmel, 682.

West Hill (Gardeau) flags and shales, Devonian, New York: Luther, 786.

West River shale, Devonian, New York: Luther, 786.

West Union hed, Silurian, Ohio: Foerste, 409.

Weverton sandstone, Cambrian, Pennsylvania: Stose, 1119.

Weverton sandstone, Cambrian, Virginia: Bassler, 78.

Whirlpool sandstone, Silurian, New York: Grabau, 472.

White River formation, Oligocene, North Dakota: Leonard, 758.

White River formation, Tertiary, Montana: Douglass, 348.

White River formation, Tertiary, Wyoming: Shaw, 1054.

White River group, Tertiary, South Dakota: Darton, 307 .

Whitetail formation, Tertiary, Arizona: Truesdell, 1155 .

Whitewood limestone, Ordovician, South Dakota: Darton, 307, 310.

Whitewood limestone, Ordovician, Wyoming and South Dakota: Darton, 306.

Willard shales, Carboniferous, Kansas: Haworth and Bennett, 518 . 
Winchester limestone, Ordovician, Kentucky: Matson, 827.

Windy Gap limestone, Carboniferous, West Virginia: Hennen, 537.

Winfield formation, Carboniferous, Kansas: Haworth and Bennett, 518.

Winnipegosan series, Devonian, Manitoba: Dowling, 350.

Wisconsin glacial epoch, Quaternary, Illinois and Iowa: Carman, 198.

Wisconsin, Pleistocene, Ontario: Coleman, 269.

Wisconsin drift, Pleistocene, Iowa: Calvin, 187.

Wisconsin drift, Pleistocene, New Jersey: Kümmel, 682.

Wissahickon mica gneiss, pre-Cambrian, Pennsylvania: Bascom, 73; Bascom et al., 74, 75.
Woodbine formation, Cretaceous, Texas: Gordon, 465.

Woodbury clay, Cretaceous, New Jersey: Bascom et al., 74, 75; Kümmel, 682 .

Woodford chert, Devonian, Oklahoma: Girty, 457. Wreford limestone, Carboniferous, Kansas: Haworth and Bennett, 518.

Yakutat group, Mesozoic?, Alaska: Tarr and Butler, 1138.

Yarmouth interglacial epoch, Quaternary, Illinọis and Iowa: Carman, 198.

Yarmouth interglacial interval, Pleistocene, Iowa: Calvin, 187.

Yeso formation, Pennsylvanian, New Mexico: Lee, 745.

$\mathrm{O}$ 